\title{
POTTER'S CYCLOPAEDIA OF
}

BOTANICAL DRUGS \& PREPARATIONS 
GIFT OF EMMA D. MENNINGER

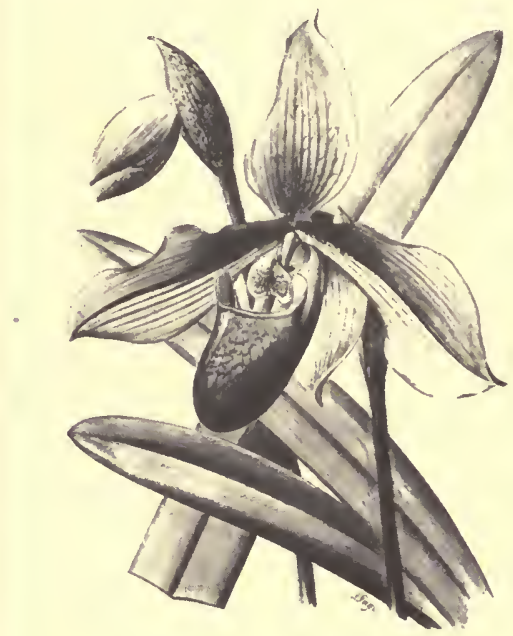

UNIVERSITY OF CALIFORNIA, IRVINE LIBRARY 


\section{POTTER'S \\ CYCLOPADIA}

OF

\section{BOTANICAL DRUGS \\ AND PREPARATIONS}

SECOND EDITION.

By R. C. WREN, F.L.S.,

With Additions By E. M. HOLMES, F.L.S.

ALL RIGHTS RESERVED

PURLISHED BY

Potter \& Clarke, LtD., 6o, 62, \& 64, Artillery Lane,

LONDON, E. 


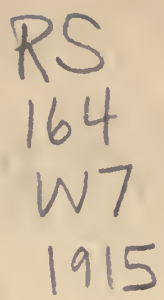

LONDON :

PRINTED BY COOPER AND BUDD, LTD., PECKHAM, S.E. 


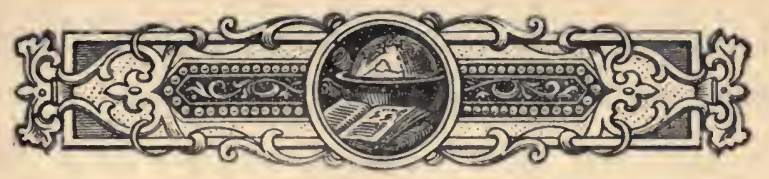

\section{Preface to Second Edition.}

In the course of only a few years many new vegetable remedies are introduced, while others drop out of use entirely. It has been our endeavour to limit the drugs herein mentioned to those which are of commercial value and which may be regarded as obtainable; consequently several additions will be noted as well as omissions from the first edition.

The notable alteration in this edition is the descriptions given of the distinctive characteristics of each drug, by which, it is hoped, the genuine article may be easily identified. Mr. E. M. Holmes, F.L.S., perhaps the best-known authority in England on medicinal plants and drugs, has kindly undertaken to be responsible for this part of the work. Mr. Holmes has also revised the botanical names of all the drugs, supplied a glossary of botanical terms and a list of authorities, 
iv. PREFACE.

and to the latter is added a characteristically interesting explanatory note on this particular subject.

It has been found necessary to omit from this edition the Indexes of Books and of Medical Receipts, but as these were compilations, and the information otherwise obtainable, the usefulness of the work is not impaired. On the other hand the additional literary matter added has not only increased the number of pages, but will, it is hoped, enhance the value of the work to a very great extent. In its present form Potter's Cyclopædia should prove useful to every person who handles drugs or herbs in either a small or large degree.

R. C. W. 


\section{Contents.}

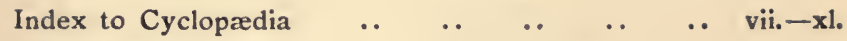

$\begin{array}{lllllllll}\text { Cyclopædia } & \ldots & \ldots & \ldots & \ldots & \ldots & \ldots & \ldots & \mathbf{I}-3^{12}\end{array}$

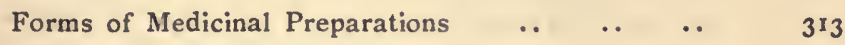

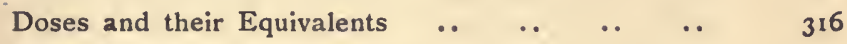

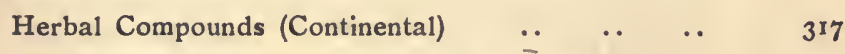

Glossary of Botanical Terms used in this Work .. $\quad 323$

Botanical Names and the Authorities for them $\quad . . \quad 333$

Abbreviations of Names of Authors of Botanical

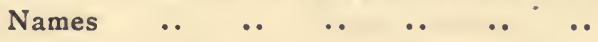




\section{Digitized by the Internet Archive in 2007 with funding from Microsoft Corporation}




\section{Index to Cyclopenda.}

Common Names are in Capitals, as in Acacia. Botanical Names are in Italics, as in Acacia Catechu. Synonyms are in Roman type, as in Adderwort.

Abelmoschus moschatus, 194 Abies Canadensis, 219 Abrus precatorius, 150 ABSCESS RoOT, 1 ACACIA, 1 Acacia Catechu, 60 Acacia, Gum, 1 Acacia Senegal, 1 Acer rubrum, 180 Achillea millefolium, 309 ACONITE, 2 Aconitum Napellus, 2 Acorus Calamus, 50 Actea racemosa, 75 Adatodai, 177 AdDer's Tongue, AMERICAN, 2 AdDER's TONGUe, ENGLish, 3 Adderwort, 28

Adhatoda Vasica, 177 Adiantum Capillus Veneris, 176 Alder, Common, 277 Adonis vernalis, 129 ADRUE, 3 Adulsa, 177 Egle Marmalos, 18 Egopodium podagaria, 120 AEsculus Hippocastanum, 136 Aethusa Cynapium, 108 African Pepper, 61 AgAR-Agar, 4
AgARIC, 4 Agaric, Larch, 4 Agaric, Purging, 4 Agaric, White, 4 Agrimonia Eupatoria, 5 AGRIMONY, 5 AGRIMONY, HEMP, 130 Agropyrum repens, 84 Ailanthus glandulosa, 285 Ailanto, 285 Ajuga Chamaepitys, 123 Ajuga reptans, 42 Alchemilla arvensis, 208 Alchemilla vulgaris, 158 Alder, Black, 5 Alder, Black, English, 5 Alder, Black, American, 6 Alder, English, 5 Alder, Buckthorn, 5 Alder, Red, 277 Alder, Smooth, 277 Alder, Spotted, 304 ALDER, TAG, 277 Alehoof, 122 Aletris farinosa, 288 Alexandrian Senna, 256 Alhenna, 132 Alicante Saffron, 243 
Alisma plantago, 297

Alkanet, 6

Alkanna tinctoria, 6

Alkekengi, 303

Allheal, 308

Allium Ascalonicum, 257

Allium Cepa, 202

Allium sativum, 113

Allspice, 7

Alnus glutinosa, 5

Alnus rubra, 277

Alnus serrulata, 277

Aloe Chinensis, 7

Aloe ferox, 7

Aloe Perryi, 7

Aloe spicata, 7

Aloe vera, 7

Aloes, 7

Aloes, Barbadoes, 7

Aloes, Cape, 7

Aloes, Socotrine, 7

Aloysia citriodora, 168

Alpinia officinarum, 110

Alsine media, 68

Alstonia BARK, 8

Alstonia constricta, 8

Alstonia scholaris, 9, 93

Althaea officinalis, 182

Althaea rosea, 132

Alumroot, 86

Amaranth, 9

Amaranthus hypochondriacus, 9

Amaranthus melancholicus, 9 American Columbo, 77

American Dogwood, 37

American Five-Leaf-Grass,

Amcrican Greek Valerian, 1

American Ground Pine, 123

AMerican Hellebore, 128

American Horsemint, 136
AMERICAN IVy, 146

American Larch, 278

AMERICAN MANDRAKE, 178

AMERICAN Liverwort, 170

American Saffron, 242

American Sarsaparilla, 246

Amcrican Sloe, 32

American SpILENARd, 267

American Valerian, 159

American White Pond Lily, 297

American Wormseed, 306

Ammoniacum, 9

Ammoniac, Gum, 9

Amomum Curcuma, 287

Ampelopsis quinquefolia, 146

Amygdalus Persica, 209

Anacardium occidentale, 58

Anacyclus Pyrethrum, 210

Anagallis arvensis, 216

Anamirta paniculata, 74

Anchusa, 6

Andira Araroba, 117

Andira inermis, 48

Anemone hepatica, 170

Anemone, Meadow, 230

Anemone pratensis, 230

Anemone Pulsatilla, 230

Anethum graveolens, 92

ANGelica, 10

Angelica Archangelica, 10

Angelica atropurpurea, 10

Angelica, Garden, 10

Angustura, True, 11

Anhalonium.Lewinii, 186

Anisa stellata, 269

Anise, 11

Anise, Chinese, 269

106 ANISEED, 11

Annatto, 12

Annotta, 12

Antennaria dioioa, 163

Anthemis Cotula, 184 
Anthemis nobilis, 64

Anthemis Pyrethrum, 210 Anthoxanthum odoratum, 290 Apium graveolens, 63 Apium petroselinum, 207 Apocynum androsamifolium, 29 Apocynum cannabinum, 53 Apocynum pubescens, 53 APPle, BitTer, 29 Apple, May, 178 Apple, Thorn, 272 Arabic, Gum, 1 Aralia nudicaulis, 20, 246 Aralia quinquefolia, 116 Aralia racemosa, 267

Araroba, 117

Arbor Vitæ, 281

Arbutus, Trailing, 12

ARchaNgel, 12

Arctium Lappa, 44

Arctostaphylos Uva-ursi, 289 Areca Catechu, 13

AREca Nut, 13

ARenaria Rubra, 13

Arillus Myristicæ, 174

Arisaema triphyllum, 293

Aristolochia Clematitis, 28

Aristolochia longa, 28

A ristolochia reticulata, 262

Aristolochia Serpentaria, 262

ARNica, 14

Arnica montana, 14

Arnotta, 12

ARRACH, 14

Arrach Stinking, 14

ARROWROOT, 14

Arrowroot, Bermuda, 14

Arrowroot, Brazilian, 280

Arrowroot, Natal, 14

Arrowroot, St. Vincent, 14

Arrowroot, Indian, 292

Arsesmart, 261
Artanthe elongata, 184

Artanthe hexagona, 26

Artemisia Abrotanum, 265

Artemisia Absinthium, 308

Artemisia Cina, 307

Artemisia chamcemelifolia, 307

Artemisia Lercheana, 307

Artemisia maritima, 307

Artemisia pauciflora, 307

Artemisia Stechmanniana, 307

Artemisia vulgaris, 192

Arum maculatum, 89

Arum triphyllum, 293

Arusa, 177

AsAFETIDA, 15

Asafetida, Gum, 15

A sagrcea officinale, 242

Asarabacca, 15

Asarum Canadense, 116

A sarum Europaeum, 15

Asclepias incarnata, 152

Asclepias procera, 51

A sclepias tuberosa, 222

Ash, 16

Ash, Bitter, 231

Ash, Common, 16

Ash, European, 16

Ash, Mountain, 189

Ash, Prickly, 227

Ash, WAFER, 292

Ash, Weeping, 16

Ashweed, 120

Asimina triloba, 206

Asparagus, 16

Asparagus officinalis, 16

Aspen, Quaking, 225

Asperula odorata, 305

Aspidium Felix-mas, 177

Aspidosperma, Quebracho.

$$
\text { blanco, } 232
$$

Asplenium Scolopendrium, 126 Asthma-weed, 101 
A stragalus gummifer, 285

Atropa Belladonna, 24

Aunée, 97

Australian Quinine, 8

Australian Febrifuge, 8

Ava, 153

Ava-pepper, 153

Avena sativa, 200

Avens, 17

Avens, Water, 17

Azadirachta, 17

Bacca Spina-cervince, 41

Badiana, 269

BAEL, 18

Bael, Indian, 18

Bahia Powder, 117

Bakás, 177

Baldmoney, 115

Ballota nigra, 135

BALM, 18

Balm, Lemon, 18

Balm, Mountain, 311

Balm, Sweet, 18

Balm of Gilead, 19

BALMONY, 19

Balsam, Peruvian, 214

Balsam Styracis, 271

Balsam Tolu, 283

Balsam Capivi, 80

Balsam Copaiba, 80

Balsam of Peru, 214

Balsam Weed, 150

Balsamodendron Myrrha, 196

BAMBOo-Brier, 20

Baptisia tinctoria, 299

Barbadoes Aloes, 7

BARBERRY, 21

BARLEY, 21

Barosma betulina, 40

Barra Gokhru, 46

Basid, 22
Basil, Sweet, 22

Basil Thyme, 50

Bastard Saffron, 242

BAYBERRY, 22

Bay, 160

Bay, Sweet, 160

Bearberry, 289

Bearsbed, 125

BeARsFoot, 23

Bearsweed, 311

Bedstraw, Crosswort, 87

Bedstraw, Ladies', 158

Bedstraw, Yellow, 158

Bel, 18

Belladonna, 24

Bengal Quince, 18

Benjamin, Gum, 25

Benne, 24

Bennet, Herb, 17

Benzoin, 25

Benzoin, Gum, 25

Benzoin, Siam, 25

Benzoin, Sumatra, 25

Berberis aquifolium, 191

Berberis dumetorum, 21

Berberis vulgaris, 21

Berbery, 21

Berberry, Holly-leaved, 191

Bermuda Arrowroot, 14

Betel Nut, 13

BETHRoOT, 26

Betel, 26

Betonica aquatica, 294

Betonica officinalis, 304

Betony, Water, 294

BetoNy, Wood, 304

Betula alba, 27

Bhang, 142

Bigarade Orange, 202

Bignonia Caroba, 56

BILBERRIES, 27

BIRCH, EUROPEAN, 27 
Birch, White, 27

Bird Pepper, 61

Birdlime Mistletoe, 188

Birds' Nest, 298

Birthroot, 26

BIRTHWORT, 28

Bishop's Leaves, 294

Bishop's-wort, 304

BISTORT, 28

Biting Persicaria, 261

Bitter Apple, 29

Bitter Ash, 231

Bitter Cucumber, 29

Bitter-herb, 19

Bitter Orange, 202

Bitter Root, 29

BitTer SWeEt, 30

Bitter Wood, 231

Bixa Orellana, 12

Black Alder, 5

BLACKBERRY, 31

BlaCK BryoNy, 39

Black Catechu, 60

Black Cohosh, 75

Black CurRaNt, 31

Black Elder, 96

Black Haw, 32

Black Hellebore, 129

BLACK Horehound, 135

Black Indian Hemp, 53

Black Larch, 278

Black Mulberry, 193

Black Pepper, 212

BLACK Root, 32

Black Sampson, 95

Black Snakeroot, 75

Black Walnut, 162

Black Willow, 301

Blackeye Root, 39

Bladder Fucus, 33

BLADDERWRACK, 33

Blanket Herb, 194
Blazing Star, 288

Blessed Thistle, 133

BLOOD ROOT, 33

Bluebottle, 82

Bluebow, 82

Blue Cohosh, 76

Blue Flag, 34

Blue Gum Tree, 100

Blug Mallow, 35

Bluet, 82

Blue Violet, 291

Blueweed, 43

Bogbean, 41

Boldea fragrans, 35

BoLdo, 35

Boldu, 35

Boletus Laricis, 4

BoNeset, 36

Bonplandia trifoliata, 11

BORAGE, 36

Borago officinalis, 36

Bottlebrush, 138

Bouncing-Bet, 264

Boxwood, 37

Brake Root, 224

Bramble, 31

Brandy Mint, 213

Brassica alba, 195

Brassica nigra, 195

Brassica sinapioides, 195

Brayera anthelmintica, 156

Brazil Powder, 117

Brazil Tea, 206

Brazilian Arrowroot, 280

Brazilian Cocoa, 125

Breakstone, Parsley, 208

Bridewort, 185

Briar, Wild, 94

Broad-leaved Tea-Tree, 49

BROoKLIME, 38

BROOM, 38

BROOM, BUTCHER's, 46 
Broom, Dyer's, 95

Broom, Irish, 38

Broom, Pine, 217

Broom, Sweet, 46

Broom Tops, 38

BROON-CORN, 39

Brownwort, 294

Brunfelsia Hopeana, 178

Bryonia, 40

Bryonia alba, 40

BRYONY, BLACK, 39

BRyony, White, 40

Bryony, Wild, 40

Buснu, 40

BuCKBEAN, 41

BUCKTHORN, 41

Budra rubra, 13

BuckTHorn, ALder, 42, 5

Buckthorn Berries, 41

Bugle, 42

Bugle, Common, 42

Bugle, Sweet, 43

Bugle, Water, 43

BugleweEd, 43

Bugloss, 43

Bugloss, Dyer's, 6

Bugloss, Spanish, 6

Bugloss, Viper's, 43

Bugula, 42

Bullnettle, 137

Burdock, 44

Burnet, Garden, 45

Burnet, Greater, 45

Burnet, Lesser, 45

Burnet, Salad, 45

Burnet, SAXIfrage, 45

Burning Bush, 292

Burra Gokeroo, 46

Burrage, 36

Burweed, 71

Bush, Burning, 292

BUTChER's BROOM, 46
BUtTERBUR, 46

Butterbur, Common, 46

Butterfly Weed, 222

Butternut, 47

ButToN SNAKEROOT, 47

Buttons, Quaker, 199

Caaroba, 56

Cabbage, Meadow, 260

Cabbage Rose, 239

Cabbage, Skunk, 260

Cabbage, Water, 297

Cabbage-Tree, 48

Cabbage-Tree, Jamaica, 48

Cabbage-Tree, Yellow, 48

CACAO, 48

Cactus grandiflorus, 197

Cactus, Sweetscented, 197

Caffea, 74

Cajuput, 49

Cajeput, 49

Calabar Bean, 50

Calamint, 50

Calamint, Common, 50

Calamintha menthifolia, 50

Calamintha officinalis, 50

Calamus, 50

Calamus aromaticus, 50

Calamus Draco, 94

Calendula, 180

Calendula officinalis, 180

California Feverbush, 103

Calisaya, 51

Calotropis, 51

Calotropis procera, 51

Calumba, 52

Caltha officinalis, 180

Camboge, 112

Camellia Thea, 280

Camellia theifera, 280

CAMPHOR, 52

Camphor, Gum, 52 
Camphor, Laurel, 52

Camphora officinarum, 52

Canada Fleabane, 107

Canada Snakeroot, 116

Canadian Hemp, 53

Canadian Moonseed, 310

Canchalagua, 54

Candleberry, 22

Canella, 54

Canella alba, 54

Cannabis Indica, 142

Cannabis sativa, 142

Cape Aloes, 7

Capivi, 80

Capivi, Balsam of, 80

Capsella Bursa-pastoris, 258

Capsicum fastigatum, 61

Capsicum minimum, 61

Caragahen, 144

Earaway, 55

Caraway Fruit, 55

Caraway Seed, 55

Carbenia benedicta, 133

Cardamom, Malabar, 55

Cardamom Seeds, 55

Cardanoms, 55

Carduus benedictus, 133

Carica papaya, 205

Caroba, 56

Carob Tree, 56

Carolina pink, 219

Carpenter's Square, 105

Carrageen, 144

Carragheen, 144

CARrot, Wild, 298

Carthamus tinctorius, 242

Carum Carvi, 55

Carum, petroselinum, 207

Caryophyllus aromaticus, 72

Casca Bark, 249

Cascara amarga, 57

Cascara Sagrada, 57
Cascarilla, 58

Cashew Nut, 58

Cassava Starch, 280

CAssia, 59

Cassia acutifolia, 256

Cassia angustifolia, 256

Cassia Bark, 59

Cassia lignea, 59

Cassuvium pomiferum, 58

Castanea dentata, 67

Castanea vesca, 67

Castanea vulgaris, 67.

Castor-Oil Bush, 59

Castor-Oil Plant, 59

Catechu, Black, 60

Catechu, Pale, 60

Catmint, 61

Catnep, 61

Catsfoot, 163

Catshair, 101

Caulophyllum thalictroides, 76

Cayenne, 61

Ceanothus Americanus, 235

Cedar, False White, 281

Cedar, Yellow, 281

Cedron, 62

Cedron-Seeds, 62

Celandine, 62

Celandine, Garden, 62

Celandine, Lesser, 216

Celandine, Small, 216

Celery, 63

Centaurea nigra, 155

Centaurea cyanus, 82

Centaury, 63

Centory, 63

Century, 63

Cephaelis Ipecacuanha, 144

Cerasus serotina, 299

Ceratonia siliqua, 151

Cereus grandiflorus, 197

Cereus, Nightblooming, 197 
Cetraria, 141

Cetraria Islandica, 141

Cevadilla, 242

Chanalivium

Carolinianum, 288

Chamcelirium luteum, 288

Сhamomile, 64

Chamomile, Dog, 184

Chamomile, German, 65

Chamomile, Roman, 64

Chamomile, Spanish, 210

Chamomile, Wild, 184

Chasse fiévre, 115

Chaulmogra, 65

Chaulmoogra, 65

Chaulmugra, 65

Chavica Betle, 26

Checker berry, 267

Cheese rennet, 158

Chekan, 66

CheKen, 66

Chelidonium majus, 62

Chelone glabra, 19
China regia, 51

Chinese Anise, 269

Chinese Cinnamon, 59

Chinese Sumach, 285

Chionanthus Virginica, 109

Chirata, 69

Chirayta, 69

Chiretta, 69

Chocolate-Tree, 48

Chondodendron

tomentosum, 207

Chondrus, 144

Chondrus crispus, 144

Chopnut, 50

Christmas Rose, 129

Chrysanthemum

cinerariafolium, 211

Chrysanthemum

Leucanthemum, 204

Chrysanthemum

Parthenium, 104

Chrysanthemum Roseum, 211

Chrysarobine, 117

Chenopodium

anthelminticum, 306

Chenopodium olidum, 14

Chequen, 66

Cherry Laurel, 66

Cherry Stalks, 67

Cherry, Wild, 299

Cherry, Winter, 303

Chervil, Sweet, 69

Chestnut, 67

Chestnut, Horse, 136

Chicken-Toe, 87

Chickweed, 68

CHICORY, 68

Chillies, 61

Chimaphila umbellata, 220

China, 68

China Orange, 203
Ciceley, Smoother, 69

Cicely, Sweet, 69

Cichorium Intybus, 68

Cimicifuga racemosa, 75

Cinchona Bark, 214

Cinchona Calisaya, 51

Cinchona flava, 51

Cinchona succirubra, 214

Cinchona, Yellow, 51

Cineraria Maritima, 70

Cinnamomum Camphora, 52

Cinnamomum Cassia, 59

Cinnamomum Zeylanicum, 70

Cinnamon, 70

Cinnamon, Chinese, 59

Cinnamon, Winter's, 302

Cinquefoil, 106

Cissus hederacea, 146
Cinnamon, White, 54 
Cissus quinquefolia, 146

Cistus Canadensis, 109

Citrullus Colocynthis, 29

Citrus acida, 166

Citrus acris, 166

Citrus Aurantium, 202

Citrus Bigaradia, 202

Citrus dulcis, 203

Citrus limetta, 166

Citrus Limonum, 162

Citrus medica, 162

Citrus vulgaris, 202

Cladonia pyxidata, 90

Clarry, 71

Clary, Sweet, 71

Claviceps purpurea, 98

Cleareye, 71

Cleavers, 71

Clivers, 71

Clover, King's, 186

Clover, Purple, 235

Clover, Red, 235

Clover, Winter, 267

Cloves, 72

Clownswort, 72

Clown's Woundwort, 308

Clubmoss, 72

Cnicus benedictus, 133

Coca, Bolivian, 73

Cocculus Indicus, 74

Cocculus palmatus, 52

Cochlearia armoracia, 138

Cochlearia officinalis, 254

Cockscomb, Red, 9

Cocoa, 48

Cocoa, Brazilian, 125

Coffea arabica, 74

Coffee, 74

Соноsh, BLack, 75

Cohosh, Blue, 76

Cola, 155

Cola Vera, 155
Colchicum, 76

Colchicum autumnale, 76

Colewort, 17

Colic Root, 300

Collinsonia Canadensis, 271

Colocynth Pulp, 29

Colombo, 52

Columbo, American, 77

ColtsFoot, 77

Coltstail, 107

Combretum, 78

Combretum Sundiacum, 78

COMFREY, 78

Commiphora Myrrha, 196

Compass Plant, 240

Compass Weed, 240

Condurango, 79

Coneflower, 95

Conium, 130

Conium maculatum, 130

Contrayerva, 79

Convallaria, 164

Convallaria majalis, 164

Convolvulus Jalapa, 148

Convolvulus Purga, 148

Convolvulus Scammonia, 251

COOLWORT, 80

Copaiba, 80

Copaifera Langsdorffi, 80

Copaiva, 80

Copaiva, Balsam, 80

Coptis trifolia, 118

Corallorhiza odontorhiza, 87

Coral Root, 87

CORIANDER, 81

Coriandrum sativum, 81

Cornbrand, 81

Cornel, Silky, 204

Corn ERGOT, 81

Corn Flower, 82

Corn Poppy, 227

Corn Rose, 227 
CoRn Silk, 82

Corn Smut, 81

Corn, Squirrel, 286

Corn, Turkey, 286

Cornus Florida, 37

Cornus sericea, 204

Corsican Moss, 83

Corydalis Canadensis, 286

Cossoo, 156

Сото, 83

Cotton, Lavander, 161

Cotton Root, 84

Cottonweed, 89

Cotula, 184

Couchgrass, 84

Coughwort, 77

Coumarouna odorata, 283

Country Sarsaparilla, 246

Cowage, 85

CoWhage, 85

Cowitch, 85

CowSLIP, 85

CRAMPBARK, 86

Cranberry, High, 86

Cranesbilli, 86

Crataegus Oxycantha, 127

Crawley Root, 87

Creeper, Virginian, 146

Crocus, 243

Crocus sativus, 243

Crosswort Bedstraw, 87

Crosswort, Common, 87

Crosswort, English, 87

Croton Eleuteria, 58

Croton Tiglium, 88

Croton Tree, 88

Crowfoot, 86

Cubebs, 88

Cuckoopint, 89

Cuckoopoint, 89

Cucumber, Bitter, 29

Cucurbita Pepo, 230
CudWeed, 89

Culver's Physic,

Culver's Root, 32

Cup Moss, 90

CUP-PLANT, 90

Cup-plant, Indian, 90

Curcuma Longa, 287

Curcuma rotunda, 287

Curcuma Zedoaria, 312

Curled Dock, 309

Currant, Black, 31

Cuscuta Epithymum, 93

Cusparia Bark, 11

Cusparia febrifuga, 11

Cusso, 156

Cutch, 60

Cydonia vulgaris, 233

Cynoglossum officinale, 139

Cynosbatos, 94

Cyperus articulatus, 3

Cypripedium hirsutum, 159

Cypripedium parviflorum, 15

Cypripedium pubescens, 159

Cytisus Scoparius, 38

Daemonorops Draco, 94

Dagga, 142

Daisy, Field, 204

Daisy, Maudlin, 204

Daisy, Moon, 204

DAISY, OX-EYE, 204

Daisy, White, 204

Dalmatian Pellitory, 211

DAMIANA, 91

Damson, Mountain, 259

DaNDELION, 91

Danewort, 95

Daphne Mezereum, 187

Datura Stramonium, 272

Daucus carota, 298

Dead Nettle, White, 12

Dead-Tongue, 295 
Deadly Nightshade, 24

Deerberry, 267

DeER's Tongue, 92

Delphinium Consolida, 160

Delphinium Staphisagria, 270

Devil's Bir, 92

Devil-Tree, 93

Dewplant, 276

Dicentra Canadensis, 286

Digitalis purpurea, 108

DiLL, 92

Dill Fruit, 92

Dill Seed, 92

Dioscorea villosa, 300

Diosma betulina, 40

Dipteryx odorata, 283

DITA BARK, 9, 93

Ditch Stonecrop, 270

Dock, Curled, 309

Dock, Red, 295

DOCK, WATER, 295

Dock, Yellow, 309

DODDER, 93

Dodder, Lesser, 93

Dog Chamomile, 184

Dog Fennel, 184

Dog Grass, 84

Dog Parsley, 108

Dog Poison, 108

Dog-Rose, 94

Dog Standard, 233

Dog Tree, 37

Dogsbane, 29

Dogstongue, 139

Dog's Tooth Violet, 2

Dogwood, American, 37

Dogwood, JAMAICA, 148

Dogwood, Swamp, 292

Dolichos pruriens, 85

Dolloff, 185

Dorema Ammoniacum, 9

Dorstenia Braziliensis, 79
Dorstenia contrayerva, 79

Dorstenia Drakena, 79

Dorstenia Houstonii, 79

Dorstenia opifera, 79

Dorstenia tubicina, 79

Downy Woundwort, 308

Dracontium fotidum, 260

Dragon Root, 293

DRAGON's BLOOD, 94

Dragon's Claw, 87

Drimys Winteri, 302

Dropwort, Hemlock, 295

DROPWORT, WATER, 295

Drosera rotundifolia, 276

Dryopteris Filix-mas, 177

Dutch Myrtle, 111

Dwale, 24

DWARF ELDER, 95

Dyer's Broom, 95

Dyer's Bugloss, 6

DYer's GreEnIEEd, 95

Dyer's Madder, 175

Dyer's Saffron, 242

Dyer's WVeed, 95

Earth Smoke, 110

East India Root, 110

East Indian Senna, 256

Easter Flower, 230

Echinacea, 95

Echinacea angustifolia, 95

Echites scholaris, 9

Echium vulgare, 43

Egyptian SoApwort Roor, 264

Elder, 96

Elder, Black, 96

Elder, DWarf, 95

Elder, European, 96

Elbcampane, 97

Elettaria Cardamomum, 55

ELM, 97

Elm, Moose, 260 
Elm, Red, 260

Ela, Slippery, 260

Embelia, 98

Embelia Ribes, 98

English Adder's Tongue, 3

English Crossivort, 87

English Gentian, 115

English Greek-Valerian, 147

English Hawthorn, 127

ENgLish HoRsemint, 137

English Knotgrass, 155

- English Liverwort, 170

English Mandrake, 40

English Rhubarb, 238

Epigae repens, 12

Equisetum arvense, 138

Erechtites hieracifolia, 105

ERGot, 98

Ergot of Rye, 98

Ergot, CoRN, 81

Erigeron Canadense, 107

Eringium campestre, 99

Eringium maritimum, 99

Eringo, 99

Eriodictyon glutinosum, 311

Erriffe, 71

ERYNGo, 99

Erythrae centaurium, 63

Erythraea Chilensis, 54

Erythronium Americanum, 2

Erythrophleum guineense, 249

Erythroxylon Coca, 73

Erythroxylon Truxillense, 73

Eschallot, 257

Eternal Flower, 99

Eucalyptus, 100

Eucalyptus Globulus, 100

Eugenia aromatica, 72

Eugenia caryophyllata, 72

Eugenia Cheken, 66

Eugenia Jambolana, 149

Euonymus atropurpurea, 292
Eupatorium cannabiunm, 130

Eupatorium perfoliatum, 36

Eupatorium purpureum, 121

EUPHORBIA, 101

Euphorbia pilulifera, 101

EUPHORBIUM, 101

Euphorbia resinifera, 101

Euphrasia officinalis, 102

European BIRCH, 27

Evening Primrose, 101

Exogonium Purga, 148

EYEBRIGHT, 102

Fabiana Imbricata, 215

Fagara Clava-Herculis, 227

False Grape, 83

False Hellebore, 129

False Jacob's Ladder, 1

False Saffron, 242

False Unicorn Root, 288

False White Cedar, 281

Featherfew, 104

Featherfoil, 104

Febrifuge, Australian, 8

Felon Herb, 192

Felonwood, 30

Felonwort, 30

Felwort, 115

Fennel, 102

Fennel, Dog, 184

Fennel Water, 296

Fenugreek, 103

Fern, Male, 177

Fern, Male Shield, 177

Ferula fotida, 15

Ferula galbaniflua, 111

Ferula Sumbul, 275

Fever Bark, 8

Feverbush, 103

Feverbush, California, 103

Feverfew, 104

Feverwort, 63 
Ficus Carica, 104

Field Daisy, 204

Field Gentian, 115

Field Sorrel, 257

Fig, 104

FigworT, 105

Fir, Scotch, 217

Fireweed, 105

Fish Berries, 74

Fivefinger, 106

Five-Leaf-Grass, 106

Five-Leaf.Grass, American, 106

Flag, Blue, 34

Flag Lily, 34

Flag, Poison, 34

Flag, Sweet, 50

Flag, Water, 34

Flag, Yellow, 310

Flake Manna, 179

Flax, Mountain, 190

Flax, Purging, 190

Flax Seed, 166

Flaxweed, 107

Fleabane, 107

Fleabane, Canada, 107

Florentine Orris, 203

Flores Carthami, 242

Flores Rhœeados, 227

Flower-de-luce, 310

Fluellin, 107

Flux Herb, 311

Fly Trap, 220

Fœniculum dulce, 102

FoOL's PARsLex, 108

Foxglove, 108

Foxglove, Purple, 108

Fragaria vesca, 273

Fragrant Sumach, 274

Frankenia grandifolia, 311

Franciscea uniflora, 178

Frasera Canadensis, 77
Frasera Carolinensis, 77.

Frasera Walteri, 77

Fraxinus excelsior, 16

Fraxinus Ornus, 179

Fringetree, 109

Frostweed, 109

Frostwort, 109

Fucus, Bladder, 33

Fucus Helminthocorton, 83

Fucus vesiculosis, 33

Fuller's Herb, 264

Fumaria officinalis, 110

FUMitory, 110

Galanga, 110

Galangal, 110

Galbanum, 111

Galbanum, Gum, 111

Galbanum Gummiresin, 111

GALE, SWEET, 111

Galega officinalis, 118

Galipea Cusparia, 11

Galipea officinalis, 11

Galium aparine, 71

Galium cruciata, 87

Galium verum, 158

Galls, 112

Gambir, 60

GAMBOoE, 112

Ganjah, 142

Garcinia Hanburii, 112

Garcinia Morella, 112

Garget, 223

GARLIC, 113

Garlic Sage, 305

Garrya Fremontii, 103

Gatinais Saffron, 243

Gaultheria procumbens, 303

Gelidium Amansii, 4

Gelsemium, 113

Gelsemium nitidum, 113

Gelseinium sempervirens, 113 
Genista Tinctoria, 95

GentIAN, 114

Gentian, English, 115

Gentian, Field, 115

Gentiana campestris, 115

Gentiana lutea, 114

Geoffrcya inermis, 48

Geranium maculatum, 86

German Chamomile, 65

Germander, 115

Germander, Water, 296

Geum urbanum, 17

Gillenia, 143

Gillenia stipulacea, 143

Gillenia trifoliata, 143

Gill-go-over-the-ground, 122

Gingelly, 24

GINGER, 115

Ginger, Indian, 116

GiNGER, WiLd, 116

Ginsen, 116

Ginseng, 116

Gipsyweed, 43

GLADWIN, 117

Gladwin, Stinking, 117

Gladwine, 117

Glechoma hederacea, 122

Gleditschia, 117

Gleditschia Ferox, 117

Gleditschia triacanthos, 117

Glycyrrhiza glabra, 168

Gnaphalium citrinum, 99

Gnaphalium dioicum, 163

Gnaphalium obtusifolium, 89

Gnaphalium polycephlaum, 89

Gnaphalium Stoechas, 99

GOA POWDER, 117

GOAT'S RUE, 118

Gokeroo, Burra, 46

Gokhru, Barra, 46

Gold Thread, 118

Gold, Vegetable, 118
Golden RoD, 119

Golden Seal, 119

Golden Senecio, 163

Goldens, 204

Goldilocks, 99

Gonolobus Condurango, 79

Goose-bill, 71

Goose-foot, 14

Goose-grass, 71

Gossypium herbaceum, 84

Goutweed, 120

GouTwORT, 120

Grape, False, 83

Grape, Mountain, 191

Grape, Oregon, 191

Gratiola officinalis, 127

Gravel Plant, 12

Gravel Root, 121

Gravelweed, 121

Great Ox-eye, 204

Great Wild Valerian, 289

Greater Burnet, 45

Greek Valerian, American, 1

Greek Valerian, 147

Greek Valerian, English, 147

Green Hellebore, 128

Greenweed, 95

Greenweed, Dyer's, 95

GRINDELIA, 121

Grindelia camporum, 121

Grindelia, Hardy, 121

Grindelia robusta, 121

Grindelia, Scaly, 121

Grindelia squarrosa, 121

Groats, 200

Ground Ash, 120

Ground Holly, 220

Ground IVY, 122

Ground Laurel, 12

Ground Liverwort, 170

Ground Moss, 125

Ground Pine, European, 123 
Ground Pine, American, 123

GROUNDSEL, 124

Grounsel, 124

Guaiacum, 124

Guaiacum officinale, 124

Guaiacum sanctum, 124

GUARANA, 125

Guaza, 142

Guelder Rose, 86

Guimauve, 182

Guinea Pepper, 61

Guinea Rush, 3

Gum Acacia, 1

Gum Ammoniac, 9

Gum Arabic, 1

Gum Asafoetida, 15

Gum Benjamin, 25

Gum Benzoin, 25

Gum Camphor, 52

Gum Galbanum, 111

Gum Kino, 154

Gum Plant, 121

Gum Tragacanth, 285

Gum-Tree, Blue, 100

Guru Nut, 155

Gutta-Cambodia, 112

Gutta-Gamba, 112

Gypsophila Struthium, 264

Hackmetack, 278

Haematoxylon, 172

Haematoxylon

campechianum, 172

Hagenia abyssinica, 156

Hair Cap Moss, 125

Hamamelis Virginiana, 304

HARDHACK, 126

Hardy Grindelia, 121

HART's TONGUE, 126

Haw, 127

HAw, BLACK, 32

Hawkweed, 192
HAWTHORN, 127

Hawthorn, English, 127

Haymaids, 122

Hayriffe, 71

Hazelwort, 15

Heal-all, 255

HeARTSEAse, 127

Hedeoma pulegioides, 117

Hedera Helix, 145

Hedge-Hyssop, 127

Helianthemum Canadense, 109

Helianthus annuus, 276

Helichrysum Stoechas, 99

HELLEBORE, AMERICAN, 128

Hellebore, Black, 129

Hellebore, False, 129

Hellebore, Green, 128

Hellebore, Swamp, 128

Helleborus niger, 129

Helminthocorton Alsidium, 83

Helonias dioica, 288

Helonias lutea, 288

Hemidesmus, 246

Hemidesmus Indicus, 246

HemLock, 130

Hemlock Bark, 219

Hemlock Dropwort, 295

Hemlock, Poison, 130

Hemlock, Spotted, 130

Hemlock Spruce, 219

Hemlock, Water Dropwort, 295

Hemp Agrimony, 130

Hemp, Black Indian, 53

Hemp, Canadian, 53

HEMP, INDIAN, 142

Henbane, 131

HENNA, 132

Henne, 132

Hepatica triloba, 170

Herb Bennet, 17

Herb, Bitter, 19

Herb, Blanket, 194 
Herb, Fuller's, 264

Herb, Gerarde, 120

Herb-of-Grace, 241

Herb, Louisa, 168
Houseleek, 139

Houseleek, Common, 139

Huckleberries, 27

Hulm, 132

Herb, Queen-of-the-Meadow, 185 Hulverbush, 132

Herbygrass, 241

Herniaria glabra, 241

Hibiscus Abelmoschus, 194

Hieracium pilosella, 192

Hippocastanum vulgare, 136

High Cranberry, 86

Hip Tree, 94

Hippo, Indian, 143

Hoarhound, 135

Hogbean, 131

HoLLy, 132

Holly, Ground, 220

HoLLYHOCK, 132

Hollyhock, Common, 132

Hollyhock, Garden, 132

Holly-leaved Berberry, 191

Holm, 132

Holy THISTLE, 132

HONEYSUCKLE, 133

Honeysuckle, Italian, 133

Hops, 134

Hop Tree, 292

Hordeum distichon, 21

HOREHOUND, 135

HOREHOUND, BlaCK, 135

Horsebalm, 271

Horse Chestnut, 136

Horsegowan, 204

Horsehoof, 77

Horsemint, 136

Horsemint, American, 136

Horsemint, English, 137

HoRsENETTLE, 137

Horseradish, 138

HoRsetall, 138

Horseweed, 271

Houndstongue, 139
Hundredleaved Rose, 239

Hurtleberries, 27

Hurtsickle, 82

Hydrangea arborescens, 140

Hydrangea, Wild, 140

Hydrastis Canadensis, 119

Hyoscyamus niger, 131

Hypericum perforatum, 269

HySSOP, 140

Hyssopus officinalis, 140

Iceland Lichen, 141

ICELAND Moss, 141

Ignatia amara, 142

IgNatius BEANS, 142

Ilex Aquifolium, 132

Ilex Paraguensis, 206

Illicium verum, 269

Impatiens Aurea, 150

Impatiens Biflora, 150

Impatiens fulva, 150

Impatiens pallida, 150

Imperatorea Ostruthium, 183

Indian Arrowwood, 292

Indian Bael, 18

Indian Cup Plant, 90

INDIAN HEMP, 142

Indian Hemp, Black, 53

Indian Hippo, 143

Indian Liquorice, 150

Indian Physic, 143

Indian Pink, 219

Indian Poke, 128

INDIAN SARSAPARILLA, 246

Indian Tobacco, 171
Humulus Lupulus, 134

HydRANGEA, 140 
IXDIGO, WILD, 299

Indigo-weed, 299

Inkroot, 254

Insect-Flowers, 211

Insect-Powder, 211

Inula Helenium, 97

Ipecac, 144

IPECACUANHA, 144

Ipomaea Jalapa, 148

Ipomaea Purga, 148

Ipomœa turpethum, 287

Iris aquatica, 310

Iris florentina, 203

Iris fœtidissima, 117

Iris lutea, 310

Iris Pseudacorus, 310

Iris versicolor, 34

Iris, Yellow, 310

Irish Broom, 38

IRISH Moss, 144

Isinglass, Japanese, 4

ISPAGHUL, 145

Italian Honeysuckle, 133

Itchweed, 128

IvY, 145

IVY, AMERICAN, 146

Ivy, Common, 145

IVY, GROUND, 122

Ivy, Poison, 222

JABORAND! 146

Jacaranda Caroba, 56

Jacaranda procera, 56

Jack-in-the.Pulpit, 293

JACOB'S LADDER, 147

Jacob's Ladder, False, 1

JALAP, 148

Jamaica Cabbage-Tree, 48

Jamalca Dogwood, 148

Jamaica Pepper, 7

Jamaica SARSAParilla, 247

Jamboo, 149
Jambool, 149

JAMBUL, 149

James's Tea, 157

Jamestown-weed, 272

Janipha Manihot, 280

Japanese Isinglass, 4

Jasmine, Yellow, 113

Jateorhiza Calumba, 52

Jatropha Manihot, 280

Java Plum, 149

JEQUIRITY, 150

Jersey Tea Root, 235

Jesuit's Tea, 206

Jewels, Speckled, 150

JEWEL WEed, 150

Jimson Weed, 272

JoHNS BREAD, 151

Joubarbe de toits, 139

Juglans cinerea, 47

Juglans nigra, 294

JUJUBE BERRIES, 151

JUNIPER BERRIES, 152

Juniperus communis, 152

Juniperus Sabina, 250

JURUBEBA, 152

Justicia Adhatoda, 177

Kalmia, 191

Kalmia latifolia, 191

KaMaLA, 153

Kameela, 153

Kava, 153

KaVA-Kava, 153

Kelpware, 33

Kidneywort, 170

King's Clover, 186

KıNo, 154

Kino, Gum, 154

KNAPWEED, 155

Kneeholm, 46

Kneeholy, 46

Knight's-Spur, 160 
Knitbone, 78

Knob Root, 271

Knobweed, 271

Knotgrass, English, 155

KNOTGRass, Russian, 155

KOLA, 155

Kola Nut, 155

Kooso, 156

Kosso, 156

Kousso, 156

Krameria argentea, 236

Krameria triandra, 236

Kusso, 156

LABRADOR TEA, 157

LACHNANTHES, 157

Lachnanthes tinctoria, 157

Lacmus, 169

Lactuca virosa, 162

LAdies' Bedstraw, 158

LAdies' MaNTLE, 158

LAdIES' SLIPPER, 159

Ladies' Slipper, Yellow, 159

Lad's Love, 265

Lady-of-the-meadow, 185

Lambkill, 191

Lamb's Quarter, 26

Lamium album, 12

Lappa, 44

Lappa minor, 44

LARCH, 159

Larch Agaric, 4

Larch, American, 278

Larch, Black, 278

Larch, European, 159

Larix Americana, 278

Larix Europcea, 159

LARIKSPUR, 160

Lark's Claw, 160

Lark's Heel, 160

LAUREL, 160

Laurel Camphor, 52
Laurel, Ground, 12

LaURel, Mountain, 191

Laurel, Noble, 160

Laurel, Roman, 160

Laurel, Sheep, 191

Laurel, Spurge, 187

Laurus Camphora, 52

Laurus nobilis, 160

Lavandula officinalis, 161

Lavandula vera, 161

LAVENDER, 161

Lavander Cotton, 161

Lawsonia alba, 132

Leaf Cup, 23

Leaf Cup, Yellow, 23

Leaf Tobacco, 282

Lecanora parella, 169

Lecanora tartarea, 169

Ledum latifolium, 157

LEMON, 162

Lemon Balm, 18

Lemon-scented Verbena, 168

Lemon, Wild, 178

Lentisk, 183

Leontice thalictroides, 76

Leontodon Taraxacum, 91

Leonurus Cardiaca, 189

Lepigonum rubrum, 13

Leptandra Virginica, 32

Lesser Burnet, 45

Lesser Celandine, 216

Lesser Dodder, 93

Lettuce-Opium, 162

LetTuce, Wild, 162

Leucanthemum vulgare, 204

LEVANT WORMSEEd, 307

Levisticum officinale, 173

Liatris odoratissima, 92

Liatris spicata, 47

Lichen caninus, 170

Lichen, Iceland, 141

Licorice, 168 
LifE-EVERLASTING, 163

LifE Root, 163

Lignum rubrum, 249

Lignum sanctum, 124

Lignum Vitæ, 124

Ligusticum Levisticum, 173

Lilium candidum, 185

Lily, Flag, 34

Lily, Liver, 34

Lily, Madonna, 185

Lily, May, 164

Lily, Meadow, 103

LiLY-OF-THE-VALLEY, 164

Lily, Snake, 34

Lily, White, 185

LIME FLOWERS, 165

LIMEFRUIT, 166

Limon, 162

Limonum, 162

Linaria vulgaris, 107

Linden flowers, 165

Linn flowers, 165

LiNSEED, 166

Linum catharticum, 190

Linum usitatissimum, 166

Lion's Foot, 158

LIPPIA, 167

Lippia Citriodora, 168

Lippia Dulcis, 167

Lippia triphylla, 168

Liquidambar orientalis, 271

Liquid Storax, 271

Liquorice, Indian, 150

LiQUORICE Root, 168

Liquorice, Wild, 150

Liriosma ovata, 193

Lithospermum tinctoria, 6

Lituus, 169

Liver Leaf, 170

Liver Lily, 34

Liverivort, AMIERICAN, 170

Liverwort, ENGLish, 170
Liverwort, Ground, 170

Liverwort, 170

Lobelia, 171

Lobelia inflata, 171

LOGwOoD, 172

Lonicera Caprifolium, 133

LOOSESTRIFE, 172

Loosestrife, Yellow, 172

Lopophora Lewinii, 186

Lords-and-Ladies, 89

Lovage, 173

Lovage, Water, 295

Love-lies-bleeding, 9

LUCERNE, 173

Lungmoss, 174

LUNGWORT, 174

Lycoperdon Bovista, 229

Lycoperdon giganteum, 229

Lycopodium clavatum, 72

Lycopodium complanatum, 123

Lycopodium Seed, 72

Lycopus Virginicus, 43

Lysimachia vulgaris, 172

MACE, 174

Macrotys actreoides, 75

Mackerel Mint, 266

MADDER, 175

Madder, Dyer's, 175

Mad-Dogweed, 297

Madweed, 253

Madonna Lily, 185

Magnolia, 176

Magnolia acuminata, 176

Magnolia glauca, 176

Magnolia tripetata, 176

Magnolia Virginiana, 176

Maidenhair, 176

Maid's-Hair, 158

Majorana hortensis, 181

Malabar Cardamoms, 55

MaLabaR-NUT, 177 
MaLe Fern, 177

Male Shield Fern, 177

Mallards, 182

Mallotus Philippinensis, 153

Mallow, Blue, 35

Mallow, Common, 35

Malva Syloestris, 35

Mamæiro, 205

MANACA, 178

Mancona Bark, 249

Mandioc, 280

Mandralie, American, 178

Mandrake, English, 40

Manihot utilissima, 280

ManNa, 179

Manna, Flake, 179

MaPle, Red, 180

Maple, Swamp, 180

Maranta arundinacea, 14

Marestail, 138

Margosa, 17

Marguerite, 204

Marigold, 180

Marigold, Garden, 180

MARJORAM, SWeEt, 181

MARJORAM, WILD, 181

Marsdenia Cundurango, 79

Marrubium nigrum, 135

Marrubium vulgare, 135

Marsh MaLlow, 182

Marsh Mint, 300

Marsh Rosemary, 254

Marsh Trefoil, 41

Maruta Cotula, 184

Maruta fotida, 184

Marygold, 180

Maryland-pink, 219

MA8TERWORT, 183

Mastic, 183

Mastich, 183

Maté, 206

Maté, Yerba, 206
Matico, 184

Matricaria Chamomilla, 65

Matricaria Pyrethrum, 210

Maudlin Daisy, 204

Mauls, 182

Mawseed, 226

May Apple, 178

May Flower, 12

May Lily, 163

May Pops, 208

MAY WeEd, 184

Meadow Anemone, 230

Meadow Cabbage, 260

Meadow LiLy, 185

Meadow Saffron, 76

Meadow Trefoil, 133

Meadow SweET, 185

Melaleuca Cajeputi, 49

Melaleuca Leucadendron, 49

Melia Azadirachta, 17

MeLiLOT, 186

Melilotus officinalis, 186

Melissa officinalis, 18

Melon Tree, 205

Menispermum Canadense, 310

Mentha aquatica, 300

Mentha piperita, 213

Mentha pulegium, 211

Mentha sativa, 300

Mentha spicata, 266

Mentha sylvestris, 137

Mentha viridis, 266

Menyanthes trifoliata, 41

Mescal Buttons, 186

Mespilus aucuparia, 189

Metroxylon Rumphii, 244

Mexican Lippia, 167

Mezereon, 187

Milfoil, 309

Milk Weed, 29

Mint, Brandy, 213

Mint, Mackerel, 266 
Mint, Marsh, 300

Mint, Mountain, 50

Mint, Wild, 300

Mistletoe, 188

Mistletoe, Birdlime, 188

Mistletoe, European, 188

Mitchella repens, 267

Mitrewort, 80

Monarda punctata, 136

Monkshood, 2

Monsonia, 188

Monsonia ovata, 188

Moon Daisy, 204

Moonseed, 310

Moonseed, Canadian, 310

Moonseed, Sarsaparilla, 310

Moose Elm, 260

Morus nigra, 193

Mother-of-Thyme, 282

Mother's Heart, 258

MOTHERWORT, 189

Mountain Ash, 189

Mountain Balm, 311

Mountain Damson, 259

Mountain Flax, 190

Mountain Grape, 191

Mountain Laurel, 191

Mountain Mint, 50

Mountain Pink, 12

MOUSEAR, 192

Mouth Root, 118

Mucuna pruriens, 85

Mudar Bark, 51

MugWORT, 192

MUIRAPUA 193

MULBERRY, 193

Mulberry, Black, 193

Mullein, 194

Muscal Buttons, 186

Musk Root, 275

Muskseed, 194

Mustard, 195
Myrica cerifera, 22

Myrica Gale, 111

Myristica fragrans, 174, 198

Myristica officinalis, 198

Myroxylon Pereive, 214

Myroxylon Toluifera, 283

MYRRH, 196

Myrrhis odorata, 69

Myrtle, Dutch, 111

Myrtus Cheken, 66

Naked Ladies, 76

Nanny, Stinking, 233

Nard, Wild, 15

Natal Arrowroot, 14

Nepeta Cataria, 61

Nepeta glechoma, 122

Nerve root, 159

Netrle, 197

Nettle, Stinging, 197

Nicotiana Tabacum, 282

Nightblooming Cereus, 197

Nightshade, Deadly, 24

Nightshade, Woody, 30

Nim, 17

Nipbone, 78

Noah's-Ark, 159

Noble Laurel, 160

Nosebleed, 309

Nut, Areca, 13

Nut, Betel, 13

Nut, Cashew, 58

Nut, Malabar, 177

Nut, Poison, 199

Nutgalls, 112

Nutmig, 198

Nux moschata, 198

Nux Vomica, 199.

Nymph, Water, 297

Nymphcea odorata, 297

OAK, 200 
Oak-Lungs, 174

OAK, POISON, 222

OATS, 200

Ocimum basilicum, 22

Oenanthe crocata, 295

Oenanthe Phellandrium, 296

Oenothera biennis, 101

Ofbit, 92

Oilnut, 47

Old-field Pine, 217

Old-Man, 265

Old-Man's Beard, 109

Old-Woman, 308

Olea Europaca, 201

Olive, 201

Olive, Spurge, 187

ONION, 202

Ophelia Chirata, 69

Ophioglossum vulgatum, 3

Opium Antidote, 78

Opopanewort, 308

Opuntia decumana, 198

Orange, Bigarade, 202

Orange, BitTer, 202

Orange, China, 203

Orange, Portugal, 203

Orange Root, 119

Orange, Seville, 202

Orange, Sweet, 203

Orchanet, 6

Orchis latifolia, 244

Orchis maculata, 244

Orchis mascula, 244

Ordeal Bean, 50

Oregon Grape, 191

Orellana, 12

Origanum majorana, 181

Origanum vulgare, 181

Orleana, 12

ORRIS, 203

Orris, Florentine, 203

Orris Root, 203
Oryza sativa, 238

Osier, Red, 204

Ourouparia Gambir, 60

Oxalis Acetosella, 306

OX-Eye Daisx, 204

Ox-eye, Great, 204

Pæonia, 212

Pceonia officinalis, 212

Paigles, 85

Pale Rose, 239

Pale Touch-me-not, 150

Palma Christi, 59

Panama Bark, 263

Panax quinquefolium, 116

Panay, 308

Pansy, Wild, 127

Papaver Rhoeas, 227>

Papaver somniferum, 226

PAPAW, 205

Papaya vulgaris, 205

Papooseroot, 76

Paraguay Tea, 206

PAREIRA, 207

Pareira brava, 207

Parietaria officinalis, 210

Parilla, Yellow, 310

PARSLEY, 207

Parsley Breakstone, 208

Parsley Piert, 208

Parsley, Poison, 130

Partridge berry, 267

Pasque Flower, 230

Passe Flower, 230

Passiflora incarnata, 208

Passion Flower, 208

Patchouli, 209

Paullinia cupana, 125

Paullinia sorbilis, 125

Pawpaw Seed, 206

Pawpaw, 205

Pea, Turkey, 286 
РeACH, 209

Pearl Barley, 21

Pearl Flower, 207

Pearl Sago, 244

Pedalium Murex, 46

Pellitory, 210

Pellitory, Dalmatian, 211

Pellitory-OF-THe-Wall, 210

Pellitory, Persian, 211

Pellitory Root, 210

Pellitory, Spanish, 210

Pellote, 186

Peltigera canina, 170

Pennyroyal, 211

Pennyroyal, American, 117

Pennyroyal, European, 211

Pennsylvania Sumach, 274

Penthorum, 270

Penthorum sedoides, 270

Peony, 212

Peony, Common, 212

Pepper, 212

Pepper, African, 61

Pepper, Bird, 61

Pepper, Black, 212

Pepper, Guinea, 61

Pepper, Jamaica, 7

Pepper, Water, 261

Peppermint, 213

Periclimenum, 133

PerivinkLE, 213

Periwinkle, Greater, 213

Perlatum, 21

Persian Pellitory, 211

Persicaria, Biting, 261

Persica vulgaris, 209

Persio, 169

Peruvian Balsam, 214

Peruvian Bark, 214

Peruvian Rhatany, 236

Petasites vulgaris, 46

Petit chéne, 115
Petroselinum sativum, 207

Pettigree, 46

Pettymorrel, 267

Peucedanum graveolens, 92

Peumus Boldus, 35

Pheasant's Eye, 129

Phellandrium aquaticum, 296

Phyllitis Scolopendrium, 126

Physalis Alkekengi, 303

Physic, Culver's, 32

Physic, Indiax, 143

Physic Root, 32

Physostigma venenosum, 50

Phytolacca decandra, 223

PICHI, 215

Picraena excelsa, 231

Picramnia Antidesma, 57

Pigeon Berry, 223

Pilewort, 216

Pilocarpus Jaborandi, 146

Pilosella, 192

Pimenta officinalis, 7

Pimento, 7

Piper Betle, 26

Pimpernel, Red, 216

Pimpernel, Scarlet, 216

Pimpernel, Water, 38

Pimpinella Anisum, 11

Pimpinella Saxifraga, 45

PINE, 217

Pine, Broom, 217

Pine, Ground, European, 123

Pine, Old-fleld, 217

Pine, Prince's, 220

Pine, Scotch, 217

Pine, Swamp, 217

Pine, White, 218

Pine, Yellow Pitch, 217

Piney, 212

Pink, Indian, 219

Pink, Mountain, 12

Pinkroot, 219 
Pink, Winter, 12

Pinus australis, 217

Pinus Bark, 219

Pinus Canadensis, 219

Pinus Larix, 159

Pinus palustris, 217

Pinus pendula, 278

Pinus pumilio, 217

Pinus Strobus, 218

Pinus sylvestris, 217

Pinus Tada, 217

Piper angustifolium, 184

Piper Cubeba, 88

Piper methysticum, 153

Piper nigrum, 212

Pipsissiwa, 220

Pipperidge Bush, 21

Piscidia Erythrina, 148

Pistacia Lentiscus, 183

Pitch Pine, Yellow, 217

Pitcher Plant, 220

Plantago decumbens, 145

Plantago Ispaghula, 145

Plantago major, 221

Plantago orata, 145

Plantain, 221

Plantain, Water, 297

Pleurisy Root, 222

Plum Tree, 229

Podalyria tinctoria, 299

Podophyllum peltatum, 178

Pogostemon Patchouli, 209

Poison Flag, 34

Poison Hemlock, 130

Poison Ivy, 222

Poison Nut, 199

PoIsON OAK, 222

Poison Parsley, 130

Poison Vine, 222

Poke, Indian, 128

POKE Root, 223

Polar Plant, 240
Polecatweed, 260

Polemonium coeruleum, 147

Polemonium reptans, 1

Polygala Senega, 255

Polygonatum multifiorum, 264

Polygonum ariculare, 155

Polygonum bistorta, 28

Polygonum erectum, 155

Polygonum Hydropiper, 261

Polymnia Uvedalia, 23

Polypodium vulgare, 224

POLYPODY RoOT, 224

Polyporus officinalis, 4

Polytrichum Juniperum, 125

Pomegranate, 224

Pond Lily, White, 297

Pool Root, 245

Poor-man's-weatherglass, 216

Poplar, 225

Poplar, White, 225

Poppy, 226

Poppy, Corn, 227

Poppy, Red, 227

Populus candicans, 19

Populus tremuloides, 225

Portugal Orange, 203

Potentilla anserina, 259

Potentilla Canadensis, 106

Potentilla reptans, 106

Potentilla Tormentilla, 284

Prepared Storax, 271

Prickly Ash, 227

Prideweed, 107

Primrose, 228

Primrose, Evening, 101

Primrose, Tree, 101

Primula veris, 85

Primula vulgaris, 228

Prince's Pine, 220

Prinos verticillatus, 6

Prune, 229

Prune Tree, 229 
Prune, Virginian, 299

Prunella vulgaris, 255

Prunus arium, 67

Prunus domestica, 229

Prunus Laurocerasus, 66

Prunus Persica, 209

Prunus serotina, 299

Psychotria Ipecacuanha, 144

Ptclea trifoliata, 292

Pterocarpus Marsupium, 154

Pterocarpus santalinus, 249

Puff Ball, 229

Pukeweed, 171

Pulp, Colocynth, 29

Pulsatilla, 230

Pumpkin, 230

Pumpkin Seed, 230

Punica Granatum, 224

Purging Agaric, 4

Purging Flax, 190

Purple Clover, 235

Purple Foxglove, 108

Pussy Willow, 301

Pyrcthrum parthenium, 104

Pyrethrum Roseum, 211

Pyrus aucuparia, 189

Pyrus Cydonia, 233

Qualser Buttons, 199

Quaking Aspen, 225

Quassia, 231

Quassia amara, 231

Quebracho, 232

Queen-of-the-Meadow Herb, 185 Rhamnus cathartica, 41

Queen-of-the-Meadow Root, 121 Rhamnus Frangula, 5, 42

Queen's Delight, 232

Queen's Root, 232

Quercus Lusitanica, 112

Quercus Robur, 200

Quickgrass, 84

Quillaia, 263

Quillaja Saponaria, 263
Quince, 233

Quince, Bengal, 18

Quince Seed, 233

Quinine, Australian, 8

Racoonberry, 178

Radix caryophyllata, 17

Ragged Cup, 90

Ragweed, 233

RAGWORT, 233

Ramp, 89

Ranunculus Ficaria, 216

RASPBERRY, 234

Rattleroot, 75

Rattleweed, 75

Red Alder, 277

Red Bark, 214

Red Clover, 235

Red Cockscomb, 9

Red Dock, 295

Red EIm, 260

Red Maple, 180

Red Osier, 204

Red Pimpernel, 216

RED Poppy, 227

Red River Snakeroot, 262

RED Root, 235

Red Rose, 239

Red Rot, 276

Red Sage, 236

Red Sandalwood, 249

Red Saunders, 249

Red Willow, 204

Rhamnus Purshiana, 57

Rhatanhia, 236

Rhatany, Peruvian, 236

Rheum officinale, 237

Rheum rhaponticum, 238

Rheum palmatum, 237

Rheumatism Root, 300 
RHUbarb, EAst INDIAN, 237

Rhubarb, China, 237

RHUBARB, TURKEY, 237

RHUdarb, ENGlish, 238

Rhus aromatica, 274

Rhus glabra, 274

Rhus Toxicodendron, 222

Ribes nigrum, 31

Rice, 238

Rich Leaf, 271

Rich Weed, 271

Ricinus communis, 59

Ringworm Powder, 117

Ripple Grass, 221

Robinsrye, 125

Rocella Montaguel, 169

Roccella tinctoria, 169

Rock brake, 224

Rock Polypody 224

Rock Rose, 109

Roman Chamomile, 64

Roman Laurel, 160

Rosa canina, 94

Rosa centifolia, 239

Rosa gallica, 239

Rose, Cabbage, 239

Rose, Christmas, 129

Rose, Corn, 227

Rose Flowers, 239

Rose, Guelder, 86

Rose, Hundredleaved, 239

Rose, PALE, 239

Rose, ReD, 239

Rose, Rock, 109

Rose Willow, 204

Rosecoloured Silkweed, 277

Rosemary, 240

Rosemary, Marsh, 254

Rosemary, Wild, 158

Rosenoble, 105

Rosinweed, 240

Rosmarinus officinalis, 240
Rottlera tinctoria, 153

Roundleaved Sundew, 276

Rowantree, 189

Rubia sylvestris, 175

Rubia tinctorum, 175

Rubus fructicosus, 31

Rubus Idceus, 234

Rubus strigosus, 234

Rubus villosus, 31

Rubywood, 249

RUE, 241

Rue, Garden, 241

Rumex acetosa, 265

Rumex Acetosella, 257

Rumex aquaticus, 295

Rumex crispus, 309

RUPTUREWORT, 241

Ruscus aculeatus, 46

Russian Knotgrass, 155

Rusticum Vulna Herba, 308

Ruta graveolens, 241

Rye, Spurred, 98

Sabadilla, 242

Sabal serrulata, 251

Sabline rouge, 13

Sacred Bark, 57

Saddleplant, 220

SAFFlower, 242

SAFFron, 243

Saffron, Alicante, 243

Saffron, American, 242

Saffron, Bastard, 242

Saffron, Dyer's, 242

Saffron, False, 242

Saffron, Gatinais, 243

Saffron, Meadow, 76

Saffron, Valencia, 243

Sage, Garden, 236

Sage, Garlic, 305

Sage, Indian, 36

SAGE, REd, 236 
SAGE, WoOD, 305

SAGO, 244

Sago Flour, 244

Sago Meal, 244

Sago, Pearl, 244

Sagus genuina, 244

Sagus Rumphii, 244

Saint Ignatius-Beans, 142

Saint James'-Wort, 233

Saint John's-Bread, 151

SAINT John's-IVort, 269

Saint Vincent Arrowroot, 14

Salad Burnet, 45

SaleP, 244

Salep Root, 244

Salix alba, 302

Salix nigra, 301

Salvia officinalis, 236

Salvia sclarea, 71

Sambucus Ebulus, 95

Sambucus nigra, 96

Sampson, Black, 95

SANDALWOOD, 245

Sandalwood, Red, 249

Sandbrier, 137

Sanguinaria Canadensis, 33

Sanguisorba officinalis, 45

Sanicle, 245

Sanicula Europaea, 245

Santalum album, 245

Santalum rubrum, 249

Santalwood, 245

Santolina

Chamocyparissias, 161

Santonica, 307

Saponaria officinalis, 264

Sarracenia purpurea, 220

Sarsaparilla, American, 246

Sarsaparilla, Country, 246

Sarsaparilla, Indian, 246

Sarsaparilla, Jamaica, 247

Sarsaparilla, Moonseed, 311
Sarsaparilla, Wild, 20

SASSAFRAS, 248

Sassafras officinale, 248

Sassafras variifolium, 248

SASSY BARK, 298

Satureia hortensis, 250

SAunders, Red, 249

Savine, 250

Savine Tops, 250

Savory, Garden, 250

SAvory, SumMer, 250

Satv Palmetto, 251

SAXifrage, Burnet, 45

Scabiosa succisa, 92

Scabwort, 97

Scaly Grindelia, 121

Scannony, 251

Scamiony Root, 252

Scarlet Berry, 30

Scarlet Pimpernel, 216

Schloss Tea, 182

Schoenocaulon officinale, 242

Scilla maritima, 268

Scolopendrium vulgare, 126

Scopolia, 252

Scopolia atropoides, 252

Scopolia carniolica, 252

Scotch Fir, 217

Scotch Pine, 217

Scouring-Rush, 138

Scrophularia aquatica, 294

Scrophularia nodosa, 105

Scullcap, 253

Scullcap, European, 253

SCURVYGRASS, 254

Scutellaria galericulata, 253

Scutellaria integrifolia, 253

Scutellaria lateriflora, 253

Sea-Holly, 99

Sea-Lavender, 254

Seaweed, 33

Seawrack, 33 
Secale cornutum, 98

Seeds, Cardamom, 55

Self-Heal, 255

Semen cinæ, 307

Semen contra, 307

Semen sanctum, 307

Semen santonici, 307

Sempervivum tectorum, 139

Senecio, Golden, 163

Senecio aureus, 163

Senecio Jacobcea, 233

Senecio maritimus, 70

Senecio vulgaris, 124

Senega, 255

Senega Snakeroot, 255

Seneka, 255

Sengreen, 139

Senna, 256

Senna, Alexandrian, 256

Senna, East Indian, 256

Senna, Tinnevelly, 256

Septfoil, 284

Serenoa serrulata, 251

Serpent's Tongue, 2

Serpyllum, 282

Sesam, 24

Sesame, 24

Sesamum Indicum, 24

Seven Barks, 140

Seville Orange, 202

Shallor, 257

Shavegrass, 138

Sheeplaurel, 191

SHeEP-SorRel, 257

Shepherd's-Barometer, 216

SHePHBRD'S-PuRSE, 258

Shepherd's-Sprout, 258

Shield Fern, Male, 177

Shrubby Trefoil, 292

Siam Benzoin, 25

Siegesbeckia, 258

Siegesbeckia orientalis, 258
Silkweed, Rosecoloured, 277

Silkweed, Swamp, 277

Silky Cornel, 204

Silphium laciniatum, 240

Silphium perfoliatum, 90

Silverleaf, 126

Silveriweed, 259

Simaba Cedron, 62

Simaruba, 259

Simaruba officinalis, 258

Sinapis alba, 195

Sinapis nigra, 195

Skullcap, 253

Skunkbush, 103

Skunk-Cabbage, 260

Slrunkweed, 260

SlipPERY Elm, 260

Smallage, 63

Small Celandine, 216

Smartweed, 261

Smilax China, 68

Smilax medica, 247

Smilax officinalis, 247

Smilax ornata, 247

Smooth Alder, 277

Smooth Sumach, 274

Smoother Cicely, 69

Smut of Rye, 98

Snake Head, 19

Snake Lily, 34

SNake Root, 262

Snakeroot, Black, 75

Snalieroot, Button, 47

Snakeroot, Canada, 116

Snakeroot, Red River, 262

Snakeroot, Texas, 262

Snakeroot, Virginia, 262

Snakeweed, 28

Snowball Tree, 86

Snowdrop Tree, 109

Snowdrop, Yellow, 2

Soap Bark, 263 
Soap root, 264

Soap Tree, 263

SOAPWORT, 264

Soapwort Root, Egyptian, 264

Socotrine Aloes, 7

Solanum Carolinense, 137

Solanum dulcamara, 30

Solanum insidiosum, 152

Solidago virgaurea, 119

Solomon's Seal, 264

Sophoria tinctoria, 299

Sorbus, 189

Sorbus aucuparia, 189

Sorghum saccharatum, 39

Sorghum vulgare, 39

Sorghum Seeds, 39

SORREL, 265

SOUTHERWWOOD, 265

Spanish Bugloss, 6

Spanish Chamomile, 210

Spanish Pellitory, 210

Spartium scoparium, 38

Spearmint, 266

Speckled Jewels, 150

Speedwell, 267

Spergularia rubra, 13

Spigelia Marilandica, 219

Spignet, 267

Spikenard, American, 267

Spikenard, Indian, 267

Spindle-Tree, 292

Spiraea stipulata, 143

Spiraea tomentosa, 126

Spiraea trifoliata, 143

Spiraea ulmaria, 185

Spiritweed, 157

Spogel, 145

Spogul, 145

Spoonwood, 153, 191

Spoonwort, 254

Spotted Alder, 304

Spotted Hemlock, 130
Spotted Touch-me-not, 150

Spruce, Hemlock, 219

Spurge Laurel, 187

Spurge Olive, 187

Spurred Rye, 98

Squaw-Root, 75

Squaw-Vine, 267

Squaw-weed, 163

SQUILl, 268

Squirrel-Corn, 286

Stachys betonica, 304

Stachys palustris, 308

Stachys sylvatica, 72

Stagbush, 32

Staggerweed, 286

Staggerwort, 233

Staphisagris, 270

Star-Anise, 269

Star-Anise Fruits, 269

Star, Blazing, 282

Star Chickweed, 68

Star Thistle, 155

Starweed, 68

Starwort, 288

Starch, Cassava, 280

Starchwort, 89

Starvesacre, 270

Statice Caroliniana, 254

Statice Limonium, 254

Stavesacre, 270

Stellaria media, 68

Sterculia acuminata, 155

Stickwort, 5

Sticta Pulmonaria, 174

Stigmata maidis, 82

Stillingia sylvatica, 232

Stinging Nettle, 197

Stinking Arrach, 14

Stinking Gladwin, 117

Stinking Nanny, 233

Stinkweed, 272

Stoechas citrina, 99 
Stonecrop, Ditch, 270

StONECROP, Virginia, 270

Stone Root, 271

Storax, 271

Storax, Liquid, 271

Storax, Prepared, 271

STRAMONIUM, 272

STRAWBERRY, 273

Strawberry-Tomato, 303

Strophanthus, 273

Strophanthus Kombe, 273

Strychnos Ignatii, 142

Strychnos Nux Vomica, 199

Styrax Benzoin, 25

Styrax, 271

Succory, 68

Succory, Wild, 68

Sulphur, Vegetable, 72

Sumach, Chinese, 285

Sumach, Fragrant, 274

Sumach, Pennsylvania, 274

Sumach, Sмоотн, 274

Sumach, SweEt, 274

Sumach, Upland, 274

Sumatra Benzoin, 25

SUMBUL, 275

SUMmer Savory, 250

SUNDEW, 276

Sundew, Roundleaved, 276

SUNFLOWER, 276

Suterberry, 227

Swallowwort, 222

Swamp Dogwood, 292

Swamp Hellebore, 128

Swamp Maple, 180

Swamp MilizweEd, 277

Swamp Pine, 217

Swamp Silkweed, 277

Swamp Tea-Tree, 49

Sweat Root,.1

Sweet Balm, 18

Sweet Basil, 22
Sweet Bay, 160

Sweet Broom, 46

Sweet Bugle, 43

SWeet Cicely, 69

Sweet Clary, 71

Sweet Chervil, 69

Sweet Flag, 50

Sweet Gale, 111

Siweet Marjoram, 181

Sweet Orange, 203

Sweet Sumach, 274

Sweet Vernal Grass, 290

Sweet Violet, 291

Sweetscented Cactus, 197

Sweet-wood Bark, 58

Swertia Chirata, 69

Symphytum officinale, 78

Symplocarpus foetidus, 260

Syrian Tragacanth, 285

Tabacca, 282

TAG Alder, 277

TAMARAC, 278

Tamarind fruit, 278

Tamarind pulp, 278

TAMARINDS, 278

Tamarindus Indica, 153, 278

Tamarindus officinalis, 278

Tamus communis, 39

Tanacetum vulgare, 279

Tanner's Bark, 200

TANSY, 279

TAPIOCA, 280

Tapioca Meal, 280

Taraktogenos Kurzii, 65

Taraxacum Dens-leonis, 91

Taraxacum officinale, 91

TEA, 280

Tea Berry, 303

Tea, Brazil, 206

Tea, James's, 157

Tea, Jesuit's, 206 
Tea, Paraguay, 206

Tea-Tree, Broadleaved, 49

Tea-Tree, Swamp, 49

Tea-Tree, White, 49

Terra Japonica, 60

Teucrium Chamaedrys, 115

Teucrium scordium, 296

Teucrium scorodonia, 305

Texas Snakeroot, 262

Thea Chinesis, 280

Theobroma Cacao, 48

Thistle, Blessed, 133

Thistle, Holy, 133

Thorn Apple, 272

Thoroughwort, 36

Thousandleaf, 309

Throatwort, 105

Thuja, 281

Thuja occidentalis, 281

ThyMe, 281

Thyme, Basil, 50

Thyme, Garden, 281

ThyMe, Wild, 282

Thymus Serpyllum, 282

Thymus vulgaris, 281

Tiarella cordifolia, 80

Tiglium, 88

Tiglium officinale, 88

Tilia argentea, 166

Tilia cordata, 165

Tilia Europcea, 165

Tilia platyphylla, 165

Tilia vulgaris, 165

Tinnevelly Senna, 256

Tissa rubra, 13

Toadfiax, 107

Товассо, 282

Tobacco, Indian, 171

Tobacco Leaf, 282

Tolu Balsam, 283

Toluifera Balsamum, 283

Toluifera, Pereirce, 214
Tonga, 156

Tonika Beans, 283

Toothache Tree, 227

TORMENTILLA, 284

Touch-me-not, Pale, 150

Touch-me-not, Spotted, 150

Tragacanth, 285

Tragacanth, Gum, 285

Tragacanth, Syrian, 285

Trailino Arbutus, 12

Treadsaf, 137

Treadsoft, 137

Tree, Cabbage, 48

Tree-Of-Heaven, 285

Tree of Life, 281

Tree Primrose, 101

Trefoil, 235

Trefoil, Marsh, 41

Trefoil, Meadow, 133

Trefoil, Shrubby, 292

Trifolium pratense, 235

Trigonella Foenum graecum, 103

Trilisia odoratissima, 92

Trillium erectum, 26

Trillium pendulum, 26

Triticum repens, 84

TRUE UnICORN ROOT, 288

True Winter's Bark, 302

Tsuga Canadensis, 219

Tuber Root, 222

TURKEY CORN, 286

Turkey Pea, 286

TURMERIC, 287

Turnera aphrodisiaca, 91

Turnip, Indian, 293

Turnip, Wild, 293

TURPETH, 287

Turpeth Root, 287

Turtle Bloom, 19

Turtle Head, 19

Tussilago Farfara, 77

Tussilago Petasites, 46 
Twitchgrass, 84

Uabano, 125

Uaranazeiro, 125

Ulmus campestris, 97

Ulmus fulva, 260

Uncaria Gambier, 60

UnicorN ROOT, FaLse, 288

UnicoRn Root, True, 288

Upland Sumach, 274

Urginea maritima, 268

Urginea scilla, 268

Urtica dioica, 197

Ustilago, 81

Ustilago Maydis, 81

UVA-URSI, 289

Uvedalia, 23

Vaccinium myrtillus, 27

Valencia Saffron, 243

VALERIAN, 289

Valerian, Greek, 147

Valerian, American, 159

Valerian, American Greek, 1

Valerian, Great Wild, 289

Valeriana officinalis, 289

Vanilla Leaf, 92

Vanilla, Wild, 92

Vegetable Gold, 118

Vegetable Sulphur, 72

Veratrum officinale, 242

Veratrum viride, 128

Verbascum thapsus, 194

Verbena hastata, 290

Verbena, Lemon-scented, 168

Verbena officinalis, 290

Verbena triphylla, 168

Vernal Grass, Sweet, 290

Veronica Beccabunga, 38

Veronica officinalis, 267

Veronica Virginica, 32

VERVAIN, 290
Viburnum Opulus, 86

Viburnum prunifolium, 32

Vinca major, 213

Viola odorata, 291

Viola tricolor, 127

VIOLET, 291

Violet Bloom, 30

Violet, Blue, 291

Violet, Dogstooth, 2

Violet, Sweet, 291

Viper's Bugloss, 43

Virginian Creeper, 146

Virginia Snakeroot, 262

Viroinia Stonscrop, 270

Virginian Prune, 299

Viscum album, 188

$V$ itis hederacea, 146

Vitis quinquefolia, 146

Vouacapoua Araroba, 117

WAFER Ash, 292

WAHOO, 292

WAKE-ROBIN, 293

Waldmeister Tea, 305

WALNUT, 294

Walnut, White, 47

Water Avens, 17

WATER Betony, 294

Water Bugle, 43

Water Cabbage, 297

Water Cup, 220

WATER DOck, 295

WATER DropWort, 295

Water Dropwort, Hemlock, 295

Water Fennel, 296

Water Flag, 34

Water Germander, 296

Water Lovage, 295

Water Nymph, 297

Water Pepper, 261

Water Pimpernel, 38

Water Plantain, 297 
Waybread, 221

Wax-berry, 22

Wax-myrtle, 22

Weeping Ash, 16

White Agaric, 4

White Birch, 27

White BRYony, 40

White Cedar, False, 281

White Cinnamon, 54

White Deadnettle, 12

White Daisy, 204

White Leaf, 126

White Lily, 185

White PINe, 218

White Pond Lily, 297

White Poplar, 225

White Tea-Tree, 49

White Walnut, 47

White-weed, 204

White Willow, 302

White-wood, 49

Whortleberries, 27

Wild Brier, 94

Wild Carrot, 298

Wild ChERRY, 299

WiLd Ginger, 116

WILD INDIGo, 299

Wild Letruce, 162

Wild Nard, 15

Wild Sarsaparilla, 20

Wild Turnip, 293

Wild Vanilla, 92

Wild Yam, 300

WILLOW, BLACK, 301

Willow, European, 302

Willow, Pussy, 301

Willow, Red, 204

Willow, Rose, 204

Willow, White, 302

Wind Flower, 230

Wind Root, 222

Wingseed, 292
Wintera aromatica, 302

Winter Cherry, 303

Winter Clover, 267

Winter Pink, 12

WINTERGREEN, 303

WINTER'S BARK, 302

Winter's Bark, True, 302

Winter's Cinnamon, 302

Witch-HAZEL, 304

Woadwaxen, 95

Wolfsbane, 2

WOOD BETONY, 304

Wood, Bitter, 231

Wood Root, 305

Wood, Yellow, 227

Woodbine, Wild, 113

Woodroof, 305

WOODRUFF, 305

WOODSAGE, 305

WOODSORREL, 306

Woodsorrel, Common, 306

Woodvine, 146

Woody Nightshade, 30

Wool Flower, 157

Worm Bark, 48

Worm grass, 219

WORMSEED, 306

Wormseed, American, 306

WORMSEED, LEVANT, 307

WORMWOOD, 308

WOUNDWORT, 308

Woundwort, Clown's, 308

Woundwort, Downy, 308

Xanthoxylum Americanum, 227

Xanthoxylum fraxineum, 227

Xanthoxylum

Carolinianum, 227

YAM, WILD, 300

YARROW, 309

Yaw Root, 232 
Yellow Bedstraw, 158

Yellow Cabbage-Tree, 48

Yellow Cedar, 281

Yellow Cinchona, 51

Yellow Dock, 309

Yellow FlaG, 310

Yellow Iris, 310

Yellow Jasmine, 113

Yellow Ladies' Slipper, 159

Yellow Leaf Cup, 23

Yellow Loosestrife, 172

Yellow Parilla, 310

Yellow Pitch Pine, 217
Yellow Root, 119

Yellow Snowdrop, 2

Yellow Wood, 227

Yerba dulce, 167

Yerba Maté, 206

Yerba Reuma, 311

Yerba Santa, 311

Zea Mays, 82

ZEDOARY, 312

Zingiber officinalis, 115

Zizyphus vulgaris, 151

Erratum :

Page 95.-Gentista should be Genista 


\section{Potter's Cyclopedia \\ OF}

\section{BOTANICAL}

\section{Drugs and PREPaRations.}

\section{ABSCESS ROOT.}

Polemonium reptans, Linn.

N.O. Polemoniacea.

Syn.-American Greek Valerian, False Jacob's Ladder, Sweatroot.

Action-Diaphoretic, astringent, alterative, expectorant. This drug has been recommended in febrile and inflammatory diseases, pleurisy, \&c. It is useful in coughs, colds, and bronchial or lung complaints. The warm infusion of $\mathrm{x}$ ounce in a pint of boiling water, taken in wineglassful doses, produces a copious perspiration.

Distinctive character-Root rhizomatous, slender, I-2 inches long, and $\frac{1}{8}$ inch in diameter, with the bases of numerous stems on the upper surface, and tufts of slender, smooth, wiry, pale, brittle roots below. Taste, slightly bitter and acrid.

ACACIA.

Syn.-Gum Acacia, Gum Arabic.

Action-Demulcent, mucilaginous. Often used as an ingredient in medicinal compounds for the treatment 
of diarrhoa, dysentery, catarrh, cough, hoarseness, fevers, \&c., when a demulcent is required.

Preparation-Syrup U.S.P.: Dose, I-4 drachms.

Distinctive character-Gum in rounded or angular pieces, which are cracked externally, transparent internally. It gives an adhesive mucilage with hot water, which is not ropy nor glairy. The mucilage keeps better if made with boiling than with cold water.

\section{ACONITE (Poison).}

Syn.-Monkshood, Wolfsbane.

Aconitum Napellus, Linn. N.O. Ranunculacea.

Action-Sedative, anodyne, febrifuge. Useful in all febrile and inflammatory diseases, scarlatina, gastritis, and facial neuralgia, also in acute catarrh, ulcerated tonsils, and croup. In palpitation and heart spasm it has been used with success. Overdoses should be carefully avoided as no certain antidote is known. Salvolatile and brandy should be given at once in cases of poisoning.

Preparations-Fluid extract, leaves: Dose, 2-4 drops. Fluid extract, root, U.S.P.: Dose, $\frac{1}{1-2}$ drops. Tincture B.P.: Dose, 2-I5 drops. Liniment B.P. Tincture U.S.P.: Dose, Io drops.

Distinctive character-Root blackish, conical above, tapering below. Internally white and starchy,-with a 5-7-angled star-shaped centre. Taste, tingling, and numbing in less than two minutes. Very poisonous. Porson-Antidotes: Emetics, ether, ammonia.

\section{ADDER'S TONGUE, AMERICAN.}

Erythroaium Americanum, Ker-Gawl. N.O. Liliacea. Syn.-Serpent's Tongue, Dog's Tooth Violet, Yellow Snowdrop.

Action-Emetic, emollient, antiscrofulous. The fresh leaves are used as a poultice in scrofulous ulcers and 
tumours, together with an infusion taken internally in wineglassful doses. Is reputed of use in dropsy, hiccough, and vomiting.

Distinctive character-Leaves, two only, lanceolate, $2 \frac{1}{2}$ inches long by I inch wide, minutely wrinkled, veins longitudinal, parallel, leafstalk 2-3 inches long. Flower yellow, starshaped, I inch wide, with six stamens. Corms slender, spindleshaped, $\frac{1}{3-I}$ inch long. Taste, sweetish. The drug should be kept in a dry place.

\section{ADDER'S TONGUE, ENGLISH.}

Ophioglossum vulgatum, Linn. N.O. Filices.

Action-Antiseptic, detergent.

Distinctive character-Leaf solitary, lanceolate, with forked veins, bearing a stalked linear spike of sporecases in a double row. Root fibrous.

ADRUE.

Cyperus articulatus, Linn.

Syn.-Guinea Rush.

N.O. Cyperacea.

Action-Anti-emetic. It possesses aromatic properties, diffusing a feeling of warmth throughout the system and acts as a sedative in dyspeptic disorders. Is particularly useful in vomiting of pregnancy, \&c.

Preparation-Fluid extract: Dose, 10-30 drops.

Distinctive character-Blackish, somewhat topshaped tubers, with bristly remains of former leaves $\frac{3}{4}-1$ inch long and $\frac{1}{2}-\frac{3}{4}$ inch in diameter, sometimes in a series of two or three connected by means of an under. ground stem $\frac{1}{8}$ inch in diameter and I-2 inches long. Transverse section pale, showing a central column with darker points indicating vascular bundles. Taste, bitterish, aromatic, recalling that of lavender. 
Syn.-Japanese Isinglass.

Action-Nutritive. The commercial varieties are used in bacteriological investigations, and for technical purposes in sizing silks and fabrics.

One ounce to 20 ounces of boiling water makes a suitable jelly for invalids, \&c. This may be flavoured with lemon or as desired. The powdered Agar in doses of I dram given with stewed fruits is recommended for constipation.

Distinctive character-In slender, shrivelled, translucent slips about $\frac{1}{4}$ inch wide and 9 or 10 or more inches long, or in quadrangular sticks about an inch in diameter; colourless and tasteless. Capable of taking up 200 times its volume of water to form a jelly.

Acetic, hydrochloric, and oxalic acids prevent its gelatinisation.

AGARIC.

Polyporus officinalis, Fries. N.O. Fungi.

Syn.-Boletus laricis, Jacq. White Agaric, Larch Agaric, Purging Agaric.

Action-Astringent, purgative. Used in small doses to check night-sweats, diarrhœa, and milk secretion after weaning. In large doses it acts as a purgative. Dose, 3-6o grains.

Distinctive character-In white, spongy, friable masses, sometimes with the lower portion attached having a porous surface of fine tubes, and a brown ringed skin on the upper surface. Taste, sweetish, then bitter and acrid. The powder shows typical threads and minute calcareous concretions. 
AGRIMONY.

Syn.-Stickwort.

Action.-Mild astringent, tonic, diuretic. Useful in coughs, simple diarrhoea, and relaxed bowels. Best mode of using is by making a decoction of $\mathrm{I}$ ounce of herb in I pint of boiling water, sweeten with honey or sugar, and take frequently in doses of half a cupful and upwards. It gives tone to the system and promotes assimilation of food.

Preparation-Fluid extract: Dose, $\frac{1}{2}-\mathrm{I}$ drachm.

Distinctive character-Leaves hairy, 5 inches or more long, having 3-5 pairs of lanceolate toothed leaflets, with intermediate smaller ones, and half-cordate, toothed stipules. Flowers small, yellow, on a long spike. Fruit small, obconical, ribbed, with hooked bristles at the apex. Taste, astringent, slightly bitter.

ALDER, ENGLISH.

Alnus glutinosa, Gaertn. N.O. Betulacea.

Distinctive character-Bark in curved or quilled pieces about $\frac{1}{20}$ inch thick, brownish grey externally, brownish orange on the inner surface. Fracture, short uneven. Taste, astringent, slightly bitter. Odour, none.

The so-called "berries" are the woody, nearly globular, female catkins, after the seeds have fallen, about $\frac{3}{8}$ inch long and $\frac{1}{2}$ inch in diameter. The scales of the catkins are ovate and undivided. Taste, astringent.

ALDER, BLACK, ENGLISH.

Rhamnus Frangula, Linn. N.O. Rhamnacer.

Syn.-Alder Buckthorn.

Distinctive character-Bark in quilled pieces $\frac{1}{25}$ inch thick, and $2-3$ or more inches long, and usually 
$\frac{1}{2}-\frac{3}{4}$ inch broad, greenish black externally with numerous elongated transverse marked lenticels, and purplish red when scraped. No stone cells visible in transverse section. Taste, nauseous and bitter.

\section{ALDER, BLACK, AMERICAN.}

Parts used-Bark, berries.

Prinos verticillatus, Linn.

N.O. Aquifoliacea.

Action-Cathartic. Used for constipation generally. Very similar in action to Cascara, to which it is preferred by some practitioners. Dose, fluid extract of bark, $\frac{1}{2}$-I drachm.

Distinctive character-Bark brownish grey, in quilled thin pieces about $\frac{1}{25}$ inch thick, with whitish patches having black margins and dark circular spots, or in older pieces short oblong transverse marks. The outer layer easily separates. Inner surface, greenish or yellowish white. Taste, bitter and astringent.

The berries resemble those of the common Holly in size, colour, and shape, and contain six cells and six seeds. The taste is bitter and somewhat acid.

\section{ALKANET.}

Alkanna tinctoria, Tausch.

N.O. Boraginacea.

Syn.-Dyers Bugloss, Spanish Bugloss, Anchusa, Orchanet, Lithospermum tinctorium, Vahl.

Action-This drug is rarely employed for its medicinal properties, which are stated to be emollient, but mostly as a colouring agent for oily or greasy compounds, such as pomades, hair oils, ointments, \&c., \&c.

Distinctive character-Root 2-4 inches long. Bark dark purplish, easily separating from the hard, porous, 
yellow, twisted woody centre; the crown of the root with hairy leaf-bases attached.

It colours paper purple, and fats and oils and spirit of wine red, but not water.

ALLSPICE.

Pimenta officinalis, Lindl.

N.O. Myrtacee.

Syn.-Pimento, Jamaica Pepper.

Action-Aromatic, stomachic, carminative. Largely used as a condiment. A good addition to other medicines in the treatment of flatulence, dyspepsia, and diarrhoea.

Preparations-Powdered fruit: Dose, 10-30 grains. Fluid extract : Dose, $\frac{1}{2}-\mathrm{I}$ drachm. Oil : Dose, 2-5 drops. Water B.P.

Distinctive Character-Fruits brown, globular, about $\frac{3}{10}$ inch in diameter, with a rough surface and a ring formed of the remains of calyx teeth at the apex. Seeds two, kidney shaped. Shell of fruit aromatic, with a mixed clove taste.

\section{ALOES.}

N.O. Liliacea.

Barbadoes Aloes B.P. is yielded by Aloe vera, Linn., and $\boldsymbol{A}$. Chinensis, Steud.; Socotrine Aloes B.P. by Aloe Perryi, J. G. Baker; Cape Aloes by Aloe Spicata, Thunb., and A. ferox, Linn., \&c.

Action-Emmenagogue, purgative, anthelmintic. Used in constipation, dyspepsia, menstrual suppressions, and piles. Generally given in pill form combined with anodynes and carminatives, also in liquid forms. Given to nursing mothers it causes purging in the suckling infant. Acts particularly on the lower bowel.

Preparations-Fluid extract: Dose, 5-30 drops. Powdered extract: Dose, I-5 grains. Comp. decoction, 
B.P.: Dose, $\frac{1}{2}-2$ ounces. Tincture B.P.: Dose, $\frac{1}{2}-2$ drachms. Aloin B.P.: Dose, $\frac{1}{2}-2$ grains. Tincture Aloes and Myrrh U.S.P.: Dose, 30 drops.

Distinctive character-Socotrine is the mildest in action and the most expensive, but varies much in quality. The powder touched with nitric acid does not give a crimson colour.

Barbadoes Aloes has a disagreeable odour and is opaque. Two grains of it are equal to three of Socotrine in purgative action.

Cape Aloes is translucent and has a red-currant odour.

Good Aloes should yield 40 per cent. of soluble matter to cold water. Both Barbadoes and Cape Aloes in powder give a crimson colour with nitric acid.

ALSTONIA BARK. Alstonia constricta, F. Muell. N.O. A pocynacea.

Syn.-Fever Bark, Australian Quinine, Australian Febrifuge.

Action-Anti-periodic, febrifuge, tonic. An Australian remedy for all kinds of fevers. Also efficacious in certain forms of rheumatism.

Preparations-Powdered bark: Dose, 2-8 grains. Fluid extract: Dose, 4-40 drops.

Distinctive character-Bark in large quilled pieces, I $\frac{1}{4}-2$ inches wide and $\frac{1}{3}$ inch thick, brown and corky externally, fissured deeply lengthwise and transversely, the inner surface yellowish brown and coarsely striated. In transverse section, a corky layer showing alternate lighter and darker bands, and an inner fibrous yellow layer in which shining particles can be seen with a lens. Taste, bitter. The yellow infusion has a blue fluorescence. 
ALSTONIA SCHOLARIS, R.Br. N.O. Apocynacea. Syn.-Echites scholaris, Linn. Dita Bark.

A native of India and the Philippines. Properties similar to Alstonia constricta.

Distinctive character-In irregular fragments $\frac{1}{8} \cdot \frac{1}{3}$ inch thick, fracture short and granular, externally rough brownish grey, often with darker spots. Internally, bright buff colour, showing numerous small medullary rays in the transverse fracture. Taste, bitter.

In the new British Pharmacopœia the name Alstonia Bark is applied to both species of alstonia.

AMARANTH. Amaranthus hypochondriacus, Linn. N.O. Amaranthacea.

Syn.-Amaranthus melancholicus, Linn. Red Cockscomb, Love-lies-bleeding.

Action-Astringent. Highly recommended in menor. rhagia, diarrbœa, dysentery, and hæmorrhages from the bowels. The decoction is taken in wineglassful doses. Externally this is used as an application in ulcerated conditions of throat and mouth, as an injection in leucorrhœa, and a wash for ulcers, sores, \&c.

Preparation-Fluid extract: Dose, $\frac{1}{2}-\mathrm{I}$ drachm.

Distinctive character-Flattened stems bearing rounded tufts of minute flowers, hidden by crowded linear, tapering, chaffy, crimson bracts. Seeds lensshaped, black, about $\frac{1}{25}$ inch in diameter.

AMmoniACUM. Dorema Ammoniacum, D. Don. Syn.-Gum Ammoniac. N.O. Umbellifera.

Action-Stimulant, antispasmodic, expectorant. Has been found especially useful in chronic affections of the 
respiratory organs, also in cough, asthma, bronchitis, catarrh, \&c.

Preparations-Powdered gum: Dose, 5-I 5 grains (10-30 gr. U.S.D.). Mixture B.P. : Dose, 4-8 drachms.

Distinctive character-The gum resin occurs in rounded nodules, or rarely compacted into masses, opaque, whitish, becoming brownish with age, fracture glossy. It forms an emulsion with water. Taste, acrid, slightly bitter. Flavour, characteristic. The solution in warm water is turned orange red by chlorinated lime.

\section{ANGELICA, EUROPEAN.}

Angelica Archangellca, Linn. N.O. Umbellifera.

Syn.-Garden Angelica.

Action-Aromatic, stimulant, carminative, diuretic, and diaphoretic. The infusion is made of $I$ ounce of herb to I pint of boiling water: Dose, a wineglassful frequently.

Preparations-Fluid extract herb: Dose, I drachm. Fluid extract root: Dose, $\frac{1}{2}-\mathrm{I}$ drachm.

Distinctive character-The European root is $2-4$ inches long and I-2 inches thick and much branched below. The transverse fracture shows numerous oil cells in the bark, and in the centre, curved yellow porous woody wedges. Taste, bitter, pungent. Flavour, characteristic sweetish and aromatic. The American root is deriver from Angelica atropurpurea, Linn. It is less branched, has a lighter colour, and is less aromatic. The fruits (or so-called seeds) are whitish, plano-convex, oblong, rounded at the ends, $\frac{1}{4}$ inch long by $\frac{1}{8}$ inch broad, winged at the margins, having three longitudinal ridges on the convex and two on the flat surface. Taste, warm, aromatic, and slightly musky. 
Syn.-Cusparia Bark. Galipea officinalis, Hal., Bonplandia trifoliata, W., Galipea cusparia, St. Hil.

Action-Aromatic bitter, tonic, stimulant. In large doses, cathartic. Recommended in diarrhœa, dysentery, intermittent fevers, and dropsy, in doses varying from 5-I 5 grains of the powdered bark. Large doses of $\frac{1}{3}-1$ drachm cause emesis and purging.

Preparations-Powdered bark: Dose, 5-I5 grains. Fluid extract: Dose, 5-30 drops.

Distinctive character-Bark in slightly curved or quilled pieces $\frac{1}{8}$ inch thick, with thin laminæ on inner surface, yellowish grey externally, outer layer sometimes soft and spongy. Transverse section, dark brown. Taste, bitter; flavour, musty.

ANISEED.

Syn.-Anise.

Action-Carminative and pectoral. Used in cough medicines and lozenges. The powdered seed is largely employed in condition and other condiments for horses.

Preparation-Oil, distilled from seeds: Dose, 4-6 drops on sugar.

\section{Water U.S.P., 3iv.}

$$
\text { " B.P. }
$$

Spirit B.P. and U.S.P.: Dose, 5-60 drops.

Distinctive character-Fruits (or so-called seeds) greyish or brownish-grey, ovate, hairy, about $\frac{2}{10}$ inch long, with Io crenate ribs, often laving the stalk attached. Taste, sweet. Odour, characteristic. They should be free from earthy matter. 
ANNATTO.

Bixa Orellana, Linn. N.O. Bixacea.

Syn.-Annotta, Arnotta, Orellana, Orleana.

Part used-Pulp of seeds.

"Annatto," the colouring matter of the pulp covering the seeds, is mostly used as a dye for fabrics, \&c., and in pharmacy to colour plasters, ointments and oils. It is also employed in various butter and cheese colours.

Distinctive character-In small circular cakes about $I \frac{1}{2}$ inches in diameter and $\frac{1}{2}$ inch thick, or in sausage-shaped rolls.

ARBUTUS, TRAILING.

Epigas repens, Linn. N.O. Ericacea.

Syn.-Gravel Plant, Ground Laurel, Mountain Pink, Winter Pink, Mayflower.

Action-Diuretic, astringent. This American plant is reputed to be superior to Buchu and Uva-ursi in all diseases of the urinary organs attended with irritation. It is of value in gravel, debilitated or relaxed bladder, and in urine containing blood or pus. The infusion of I ounce of leaves in a pint of boiling water may be drunk freely.

Distinctive character-Leaves stalked broadly ovate, I-I $\frac{1}{2}$ inches long and about I inch broad, leathery, reticulated with a cordate base and a short point at the apex. Lateral veins spreading, wavy with short hairs on the under surface. Taste, astringent and bitter. Odour, none.

ARCHANGEL.

Syn.-White Deadnettle.

Distinctive character-Stem quadrangular, leaves opposite, reticulate veined, with spreading hairs, chiefly 
on the prominent veins below, and on the stem, margin with large serrate teeth. Flowers large, white, twolipped with two long and two short stamens. Taste, sliglitly bitter. Odour, none, when dried.

ARECA NU'T.

Syn.-Betelnut.
Areca Catechu, Linn. N.O. Palmacea.

Action-Astringent, tænicide. Is chiefly used to expel tapeworms. The powdered nut is administered in doses from 2-4 drachms. The smaller dose is generally given in syrup, followed by a purgative.

\section{Preparation-Fluid extract : Dose, I-4 drachms.}

Distinctive character-Seed conical or nearly spherical, I inch or more in diameter, hard and horny, marbled with brown lines internally. Taste, astringent and slightly acrid. The larger and more conical seeds are more active than the globular variety.

ARENARIA RUBRA. Linn.

Lepigonum rubrum, Fries. N.O. Caryophyllacea.

Syn.-Spergularia vubra, Pers. Sabline rouge (Fr.). Tissa rubra, tdans. Budra rubra, Dum.

Action.-Diuretic. A popular remedy in Malta for diseases of the bladder. Recommended in cystitis, stone, \&c.

Dose of infusion, I ounce to pint, a wineglassful frequently. Fluid extract, I drachm.

Distinctive character.-Herb with jointed stems and flat linear leaves, about $\frac{x}{16}$ inch wide and nearly $\frac{1}{2}$ inch long, with ovate pointed stipules, flowers small, pink, in spreading, loose, panicles, seeds not winged. Taste, saline and slightly aromatic. 
ARNICA.

Arnica montana, Linn. N.O. Composita.

Action-Stimulant, vulnerary. Largely used as a local application to bruises, swellings, \&c. Being an active irritant, care should be exercised in internal employment. Severe and fatal cases of poisoning are on record.

Preparations-Tincture B.P., root: 20-30 minims. Tincture U.S.P., flowers : 10-30 minims.

Distinctive character-Rhizome $\frac{1}{6}-\frac{1}{4}$ inch in diameter, I-2 inches long with rather distant wing, unbranched rootlets below. Transverse fracture showing greyish pith and oil cells in the bark. Taste, acrid and bitter. Odour, like that of apples. The flowers have yellow florets, and brownish fruits, with a single row of whitish barbed hairs, and a hairy receptacle.

ARRACH.

Chenopodium olldum, S. Wats.

Syn.-Stinking Arrach, Goosefoot.

N.O. Chenopodiacea.

Action-Nervine, emmenagogue. Useful in hysteria of females and as a remedy for menstrual obstructions. The infusion of I ounce in a pint of boiling water is taken three or four times daily in wineglassful doses.

Preparation-Fluid extract: Dose, $\frac{1}{2}$-I drachm.

Distinctive character-Herb with oval, stalked leaves, about $\frac{1}{2}$ inch long, entire at the margins; having a strong fishy odour and powdery surface.

ARROWROOT.

Maranta arundinacea, Linn.

N.O. Marantacea.

Syn.-Bermuda Arrowroot, Maranta.

Action-Demulcent, non-irritating, nutritive. Well suited for infants and convalescents. Two or three teaspoonfuls may be boiled in a pint of water or milk and seasoned to taste, with sugar, lemon juice, fruit 
jellies, essences or aromatics. Other kinds are the Natal and St. Vincent Arrowroot.

Distinctive character-A white powder containing small masses consisting of the starch obtained from the root. Under the microscope seen to consist of irregularly oval grains, having the hilum at the larger end or near the middle. Average diameter, 30-40 $\mu$.

\section{ASAFETIDA.}

Ferula fœtida, Regel.

Syn.-Asafœetida, Gum Asafetida.

N.O. Umbellifera.

Action-Stimulant, antispasmodic, expectorant. Useful in infantile convulsions, croup, and flatulent colic. It allays gastric irritation, hysteria, and spasmodic nervous diseases. Owing to its nauseous taste, it is mostly given in pill form.

Preparations-Powdered gum-resin: Dose, 5-20 grains. Tincture B.P., U.S.P.: Dose, $\frac{1}{2}-I$ drachm. Emulsion U.S.P.: Dose, 4 drachms.

Distinctive character-Distinguished by its powerfully alliaceous odour. Occurs in more or less sticky lumps of variable size, sometimes with a pinkish tint. Immersed in water, and ammonia added, a bluish fluorescence appears; touched with nitric acid it gives a green colour. It is the gum resin of the roots.

ASARABACCA.

Syn.-Hazelwort, Wild Nard.

Part used-Root, herb.

Action-Emetic, purgative, sternutatory. Is stimulant in doses of IO-I2 grains; emetic in doses of I-2 drachms. In France it is said that drunkards use it to produce vomiting.

Distinctive character-Leaves kidney-shaped, leathery, stalked. Flowers solitary, bell-shaped, with 
three segments, purplish within. Rhizome slender, 2-4 inches long and $\frac{1}{8}$ inch thick, quadrangular, tortuous, thickened at intervals where rootlets are given off, with stem scars on the upper surface.

ASH.

Fraxinus excelsior, Linn. N.O. Oleacea.

Syn.-Common Ash, European Ash, Weeping Ash.

Part used-Bark, leaves.

Action-Antiperiodic, laxative, purgative. At one time the bark was extensively used in intermittent fevers, ague, \&c. The leaves are used with success in gouty, arthritic and rheumatic complaints.

Distinctive character-Bark thin, greenish or greyish brown, in curved pieces about $\frac{1}{8}$ inch thick and about $\mathrm{I} \frac{1}{2}$ inch broad, with distant longitudinal furrows, inner surface pale brown, laminated, transverse section showing many thin layers, outer surface rough and scaly in older bark. Taste, faintly bitter. Odour, none. American white ash bark has numerous small circular depressions externally, and a slightly less laminate fracture.

ASPARAGUS.

Asparagus officinalis, Linn. N.O. Liliacea.

Action-Diuretic, laxative, cardiac, sedative. It is said that this plant produces a copious diuresis, and it has been recommended in dropsy, enlargement of heart, \&c. The fresh expressed juice is taken in tablespoonful doses. It can be made more palatable in the form of a syrup and is used as such in doses of I-2 tablespoonfuls.

Distinctive character-Root about 2 inches long and $\frac{1}{2}-\frac{3}{4}$ thick with loose laminate texture internally, giving off long compressed tough rootlets several inches long, and $\frac{1}{8}-\frac{1}{4}$ inch in diameter, nearly hollow, with a central woody cord. Taste, insipid. Odour, none. 
AVENS.

Geum urbanum, Linn.

N.O. Rosacea.

Syn.-Colewort, Herb Bennet, Radix caryophyllata.

Water Avens is a distinct specie with purplish flowers. Those of $\mathrm{G}$. urbanum are yellow.

Part used-Herb and root.

Action-Astringent, styptic, tonic, febrifuge, stomachic. Its constant use is said to have a highly restorative power in weakness, debility, \&c. Also useful in diarrhœa, sore throat, and leucorrhœa. The infusion is made of $I$ ounce of powdered herb or root to I pint of boiling water and taken in wineglassful doses three or four times a day.

Preparations-Fluid extract herb: Dose, I drachm. Fluid extract root: Dose, $\frac{1}{2}-1$ drachm.

Distinctive character - Root I-2 inches long, obconical, abrupt below, hard and rough, with light brown rootlets. Transverse section light purplish brown with thin bark, a narrow woody ring and large pith. Taste, astringent, slightly bitter, with a clove flavour. Stems about I2 inches high, leaves interruptedly pinnate with the terminal leaflet large, stem leaves ternate or trifid, the whole plant having spreading hairs. Flowers purplish. Taste, astringent. Odour, none.

AZADIRACHTA.

Syn.-Nim, Margosa.

Action-Anthelmintic; it is also said to be cathartic and emetic. Used in Southern States of America for worms in children, and generally given in form of a decoction made of 4 ounces of bark to I quart of water and boiled down to a pint. Dose, a tablespoonful every 
three hours or a dose evening and morning followed by castor oil or some other active cathartic.

Preparations - Infusion (Br. Add.), $\frac{1}{2}-\mathrm{I}$ ounce. Tincture (Br. Add.), $\frac{1}{2}-\mathrm{r}$ drachm.

Distinctive character-Bark greyish brown, rough, and cracked externally; inner surface bright buff, in pieces about 2-3 inches wide and $\frac{1}{5}$ inch thick. Transverse fracture fibrous, the inner portion showing distinct layers. Taste, astringent and bitter. Odour, none.

BAEL.

AEgle Marmelos, Correa. N.O. Rutacea.

Syn.-Bel, Indian Bael, Bengal Quince.

Part used-Unripe fruit.

Action-Astringent. An Indian remedy and almost a specific for diarrhœa, dysentry, \&c. It does not constipate.

Preparation-Fluid extract: Dose, $\frac{1}{2}-2$ drachms.

Distinctive character-Fruit globular or sometimes oval, with a hard shell divided internally like an orange, flesh reddish, hard when dry, seeds numerous, covered with a gummy layer. Taste, mucilaginous, slightly acid.

BALM.

Melissa officinalis, Linn. N.O. Labiata.

Syn.-Sweet Balm, Lemon Balm.

Part used-Herb.

Action-Carminative, diaphoretic, febrifuge. Induces mild perspiration and makes a pleasant and cooling tea 
for feverish patients. To make the tea, pour I pint of boiling water upon I ounce of herb, let stand for a quarter of an hour, allow to cool, then strain and drink freely. A very useful herb, either alone or in combina. tion with others.

Preparation-Fluid extract : Dose, $\frac{1}{4}-\mathrm{I}$ drachm.

Distinctive character-Leaves opposite, stalked, about $\mathrm{I} \frac{1}{2}$ inch long, thin, broadly ovate, with a rounded base (wedge-shaped in the upper leaves), coarsely serrate and wrinkled. Taste and odour like lemon.

\section{BALM OF GILEAD.}

Populus candicans, Ait.

Part used-Buds.

N.O. Salicacea.

Action-Stimulant, tonic, diuretic. It is of great benefit in all affections of chest, lungs, stomach, and kidneys. As an ointment it is good for colds and pains in the chest, cutaneous diseases, rheumatic and gouty pains.

Preparations-Solid extract: Dose, 5-10 grains. Tincture: Dose, I-4 drachms. Fluid extract: Dose, I.2 drachms.

Distinctive character-Buds about $I$ inch long and $\frac{1}{4}$ inch broad, scales brownish, narrowly ovate, closely overlapping, polished, inner scales sticky and resinous. Odour, balsamic. Taste, balsamic and slightly bitter.

BALMONY.

Chelone glabra, Linn.

N.O. Scrophulariacea.

Syn.-Bitter Herb, Snake Head, Turtle Head, Turtle Bloom.

Part used-Leaves.

Action-Antibilious, anthelmintic, tonic, detergent. Used largely in constipation, dyspepsia, debility and 
jaundice. In all diseases of the liver it will be found very valuable, and is a certain remedy for worms in children. An infusion of I ounce to I pint of boiling water may be taken frequently in doses of a wineglassful.

Preparations-Powdered herb: Dose, 5. Io grains. Fluid extract: Dose, $\frac{1}{2}-1$ drachm. Chelonin: Dose, I-2 grains.

Distinctive character-Leaves opposite, oblong lanceolate, shortly stalked, fruits crowded in a short spike, ovate, $\frac{1}{2}$ inch long, two-celled with nearly circular, winged seeds, having a dark centre. Taste, very bitter. Odour, slightly tea-like.

BAMBOO BRIER.

Aralla nudicaulis, Linn. N.O. Avaliacea.

Syn.-Wild Sarsaparilla.

Part used-Root.

Action-Alterative, tonic, antisyphilitic. The American Indians use this as an antisyphilitic and it has been employed with success as a blood purifier in rheumatic, scrofulous and cutaneous affections. The decoction can be freely taken or it may be combined with Burdock, Poke Root, Prickly Ash, Queen's Delight, and others.

Distinctive character-Rhizome 12 or more inches long, about inch in diameter, sometimes with crowded alternate branches at the upper end bearing terminal cup-shaped scars. Bark greyish brown, spongy, longitudinally wrinkled. Transverse section showing a hard, porous, woody ring with a white central pith. Taste, mucilaginous and somewhat ivy-like. 
BARBERRY.

Berberis vulgaris, Linn.

N.O. Berberidacea.

Syn.-Berbery, Pipperidge-Bush, Berberis dumetornm, Gouan.

Part used-Bark, rootbark.

Action-Tonic, purgative, and antiseptic. Used in all cases of jaundice, liver complaints, general debility, and biliousness. It regulates the digestive powers, being a mild purgative, and removes constipation. The berries make a pleasant acid drink of great utility in diarrhœa, fevers, \&c.

Preparations--Powdered bark: Dose, $\frac{1}{4}$ teaspoonful three to four times daily. Fluid extract: Dose, $\frac{1}{2}-I$ drachm. Solid extract : Dose, 5-Io grains.

Distinctive character-Stem bark thin, externally yellowish grey, orange yellow on the inner surface, separating in layers. Root bark dark brown externally, fracture short. Taste, very bitter.

BARLEY.

Hordeum distichon, Linn. N.O. Graminacea.

Syn.-Pearl Barley, Perlatum.

Part used-Decorticated seeds.

Action-Nutritive, demulcent. As an article of diet for the sick and convalescent it is largely used. Barleywater is a demulcent food beverage for children suffering from diarrhœa, catarrhal inflammation of bowels, \&c. The decoction made from the washed Barleycorns-2 ounces to a pint of water-is an unirritating food in chronic exhausting diseases. Extract of Malt (U.S.P.) is largely manufactured from Barley and 
is a medicinal form of administration by itself and in its various combinations.

Distinctive character-Two forms of decorticated barley are sold, known respectively as Scotch hulled or Pot Barley, which is not entirely deprived of the husk, and Pearl Barley. Pearl Barley should always be washed before being boiled as it is apt to accumulate dust.

\section{BASIL.}

Syn.-Sweet Basil.

Part used.-Herb.

Action-Aromatic, carminative, cooling. Although generally employed in domestic circles for cooking and flavouring purposes, it has occasionally been used with success in medicine for mild nervous disorders. In South America the fresh juice is used as a vermifuge.

Distinctive character-Stems obtusely quadrangular. Leaves opposite, oval, lanceolate, about I inch long and $\frac{1}{3}$ inch broad, stalked, greyish green beneath and dotted with dark oil cells. Calyx with upper lobe rounded and spreading. Seeds brown and obtuse. Taste, aromatic, recalling tarragon.

BAYBERRY.

Myrica cerifera, Linn. N.O. Myricacere.

Syn.-Candleberry, Waxberry, Wax myrtle.

Part used-Bark.

Action-A powerful stimulant, astringent, and tonic. If not absolutely the most useful article in botanic practice, it is certainly nearly so. It enters largely into many of the compound powders and forms the basis of the celebrated Composition Powder. In cases of cold- 
ness of the extremities, chills, clamminess, \&c., it will, combined with cayenne, cause that action in the system which generates heat and induces perspiration. For canker of the stomach and bowels it is invaluable, being an effectual deobstruent and cleanser. The powdered bark is generally used in an infusion of $I$ ounce to $I$ pint of boiling water. To promote heat it should be drunk warm. The powder may also be added to poultices as it has a very healing and cleansing action on all scrofulous ulcers, sores, \&c.

Preparations-Powdered bark: Dose, $\frac{1}{2}$ to $\mathrm{I}$ drachm. Fluid extract: Dose, $\frac{1}{2}$ to I drachm. Myricin: Dose, I-3 grains. (See also "Composition Powder.")

Distinctive character-Bark in short quilled pieces about $\frac{1}{16}$ inch thick, with a white, peeling epidermis, covering a red-brown hard layer beneath, fracture granular, slightly fibrous on the inner surface. Taste, astringent, bitter, and pungent. Odour, slightly aromatic.

BEARSFOOT.

Polymnia Uvedalia, Linn. N.O. Composita.

Syn. - Uvedalia, Leaf Cup, Yellow Leaf Cup.

Part used-Root.

Action-Stimulant, laxative, anodyne. Has been used with good effect in congestive states of liver and spleen; also in inflamed glands and dyspepsia from these causes. Used externally as a hair tonic or in form of an ointment.

Preparation-Fluid extract : Dose, I 5-6o drops.

Distinctive character-Root greyish brown, finely furrowed longitudinally, from $\frac{1}{4}-\frac{1}{2}$ inch in diameter with a tough coarsely fibrous fracture, the woody column splitting up into laminæ, the bark thin, brittle, easily scaling off. Taste, saline, faintly bitter. Odour, none. 
Syn.-Deadly Nightshade, Dwale. N.O. Solanacere.

Parts used-Root, leaves.

Action-Narcotic, diuretic, sedative, mydriatic. Used as an anodyne in febrile conditions, night-sweats, coughs, whooping cough, \&c., also in spermatorrhoea. Suppresses grandular secretions. Used externally in gouty and rheumatic inflammations.

Preparations-Powdered leaves: Dose, I-2 grains. Fluid extract leaves: Dose, I-3 drops. Fluid extract, root, B.P.: Dose, $\frac{1}{1-1}$ drop. Tincture B.P.: Dose, 5-I5 drops. Alkaloid, Atropine, Alcoholic extract, B.P.: Dose, 1-I grain. Green extract B.P.: Dose, $\frac{1}{-1}$ I grain. Liniment B.P., Juice B.P.: Dose, 5-I 5 drops. Plaster B.P. and U.S.P. Ointment B.P.

Distinctive character-Root pale brown, $\frac{8}{8}-\frac{3}{4}$ inch in diameter, 6 or more inches long, with short transverse scars, easily abraded by the finger nail, showing white, starchy tissue beneath. Transverse section whitish, with a thickish bark, and woody bundles scattered through the central column, but more crowded near the bark.

Leaves ovate, not toothed, thin and brittle when dry, showing under a lens numerous minute, pale, prominent points on the surface, corresponding to cells filled with sandy crystals of calcium oxalate.

BENNE.

Syn.-Sesam, Gingelly, Sesame.

Parts used-Leaves, seeds.

Action-Demulcent, laxative. The fresh leaves are very usetul in catarrhal affections, diarrhoea, dysentery, affections of kidney and bladder. The Indian natives 
steep a leaf or two in water and drink the resulting mucilage freely. Externally they also apply this in ophthalmic and cutaneous complaints. The seeds contain an oil which is used in the same manner as Olive Oil and has a laxative effect. Given internally this oil is said to promote menstruation.

Distinctive character-Leaves alternate, ovate, or lanceolate, the lower ones often three-lobed, prominently veined beneath. Taste, mucilaginous. Seeds $\frac{2}{10}$ inch long, $\frac{2}{20}$ inch broad, flat, obovate, usually white or black, but there are yellowish and reddish varieties. Taste, mucilaginous, oily.

BENZOIN.

Styrax Benzoin, Dry. N.O. Styracea.

Syn.-Gum Benzoin, Gum Benjamin, Siam Benzoin, Sumatra Benzoin.

\section{Part used-Resin.}

Action-Stimulating, expectorant. Used as part of Friar's Balsam in coughs, bronchitis, and externally applied to wounds, sores, \&c. Contains Benzoic Acid and thus enters into the preparation of Paregoric.

Preparations-Benzoid acid B.P.: Dose, 5 - I 5 grains. Lozenges (Benzoic) B.P. Compound tincture benzoin B.P. and U.S.P.: Dose, $\frac{1}{2}-I$ drachm. Compound tincture camphor B.P. (Paregoric): Dose, $\frac{1}{2}-\mathrm{I}$ drachm. Tincture U.S.P.: Dose, I 5 drops.

Distinctive character-In greyish brown, resinous lumps, containing white tears. Odour, balsamic, or recalling the odour of hyacinth, in the Penang kind, and that of vanilla in the Siam kind. Giving off a fragrant odour when heated. It is soluble in spirits of wine, except for debris, which should not exceed to per cent. (and in exceptionally good specimens would not exceed 2 per cent.). 
BETH ROOT.

Trillium pendulum, Willd. and Trillium erectum, Linn.

N.O. Liliacea.

Syn.-Birthroot, Lamb's Quarter.

Part used-Root.

Action-Astringent, pectoral, alterative, and tonic. Will be found of use in all cases of internal bleeding, profuse menstruation, and pulmonary complaints. In female disorders it is especially valuable both as a medicine and as an enemata. It acts as a general astringent to the uterine organs and should be used in fluor albus, menorrhagia, \&c. The infusion, made by pouring I pint of boiling water on a tablespoonful of powder, should be drunk freely in most cases when it is required as an astringent, in doses of a wineglassful or more. In coughs, \&c., 10-20 grains of powdered root may be taken in a little water three times a day. A good antiseptic poultice may be made of equal parts of powdered Beth Root and Slippery Elm with a small quantity of powdered Lobelia Seed.

Preparations-Powdered root: Dose, 10-20 grains. Fluid extract: Dose, I-2 drachms. Trilliin: Dose, 2-4 grains.

Distinctive character-Rhizome dull brown, subconical, more or less compressed, $\mathrm{I} \frac{1}{2}-2$ inches long, and $\frac{3}{4}-\mathrm{I}$ inch in diameter, transversely ringed with numerous oblique lines, and with numerous slender transversely wrinkled rootlets on the lower surface. Transverse fracture whitish, horny, and starchy. Taste, sweet, bitterish, slightly astringent and acrid. Flavour, strong, recalling that of podophyllum.

BETEL.

Plper Betle, Linn.

Syn.-Chavica Betle, Miq. Artanthe hexagona, Miq.

Action-Astringent. Largely used by Indian natives, who chew the leaves with the Areca Nuts as a cure for relaxed bowels. 
Distinctive character-Leaves cordate below, oval, tapering above, with 5-7 radiating ribs, $2 \frac{1}{2} \cdot 3 \frac{1}{2}$ inches long, and about 2 inches broad, dark green above, paler below, with numerous transparent, minute, reddish points due to oil cells. When chewed the leaves produce a flow of saliva. Taste, feebly aromatic.

BILBERRIES.

Vaccinium Myrtillus, Linn. N.O. Vacciniacea.

Syn.-Huckleberries, Whortleberries, Hurtleberries.

Part used-Ripe fruits.

Action-Diuretic, refrigerant, astringent. The fruit may be eaten by itself or with milk and sugar as a cooling nutriment. The dried berries are used in medicine and have proved of much benefit in dropsy and gravel. A decoction of I ounce in a pint of boiling water is used in tablespoonful to wineglassful doses in diarrhœa, dysentery, and derangements of the bowels. It has been found particularly useful during typhoid epidemics in the following form: I pound Bilberries, $\frac{1}{4}$ pound Cream of Tartar, I gallon water; boil for twenty minutes, strain and make up to I gallon with water. Drink a teacupful several times a day. Externally the decoction is used as a gargle, as a wash for sores, wounds, and ulcers, and as an injection in leucorrhœea.

Preparation--Fluid extract: Dose, $\frac{1}{2}-2$ drachms.

Distinctive character-Berries blue-black, globular, with the calyx ring at the apex. Contains numerous small oval seeds. Taste, sweet acidulous. Odour, slightly valerianic.

BIRCH, EUROPEAN.

Betula alba, Linn.

Syn.-White Birch.

N.O. Betulacea.

Parts used-Bark and leaves.

Action-Bitter, astringent. The barl by destructive distillation yields Birch Tar, which is used in preparing 
Russian leather. From this tar a volatile oil--Olewm Rusci, or Oleum betulinum-is distilled. This oil has been used successfully internally for gonorrhœa, but is most highly esteemed as a remedy in cutaneous affections, especially those of eczematous nature.

Distinctive character-Leaves stalked, rhomboidal, ovate, pointed, shiny, biserrate at the margin, about I-I inch long, and $\frac{3}{4}-\mathrm{I}$ inch broad. Young bark having externally white papery layers marked with linear brown lenticels; inner dark brown, granular, with numerous hard white points, the old bark rough blackish brown outside, with white lines showing in the brown transverse section. Fracture short. Taste, astringent and bitter.

BIRTHWORT.

Part used-Root.

Action-Aromatic, stimulant. Used in rheumatism and gout.

Preparation-Powdered root: Dose, $\frac{1}{2}-\mathrm{I}$ drachm.

Distinctive character-Root somewhat cylindrical, I inch or more in diameter, externally pale brown, smooth, striated or warty. Transverse fracture whitish, with brown dots due to vascular bundles containing oleo-resin. Taste, sweetish, then acrid and disagreeable.

BISTORT.

Polygonum Bistorta, Linn. N.O. Polygonacea.

Syn.-Snakeweed, Adderwort.

Part used-Root.

Action-Astringent. Used chiefly in hæmorrhages and mucous discharges as a medicine, injection, or a gargle. 
Preparations-Powdered root: Dose, $\frac{1}{6}-\frac{1}{2}$ drachm in water. Fluid extract: Dose, $\frac{1}{2}$-I drachm.

Distinctive character-About 2 inches long and $\frac{3}{6}$ inch broad, twice bent as in the letter S, red-brown, depressed or channelled on the upper surface and transversely striated, convex, and with depressed root scars below, fracture short, light reddish brown, bark thick, ring of woody wedges small, enclosing a pith equal in thickness to the bark. Taste, astringent. Odour, none.

BITTER APPLE. Citrullus Colocynthis, Schrad. N.O. Cucurbitacea.

Syn.-Colocynth Pulp, Bitter Cucumber.

Part used-Peeled fruit.

Action-Cathartic, irritant, drastic purgative. Seldom used alone, mostly in conjunction with other laxatives and anodynes, such as Aloes, Henbane, \&c. Useful in constipation, and in painful menstrual complaints, also in dropsy. As a rule it is taken in pill form.

Preparations-Fluid extract: Dose, 5-ro drops. Comp. extract B.P.: Dose, 2-8 grains. Powdered extract U.S.P.: Dose, $\frac{1}{2}$ grain. Solid extract: Dose, 2.5 grains. Colocynthin: Dose, $1-1$ grain.

Distinctive character-Pulp yellowish white, spongy, very bitter, sometimes containing dark-greeenish oval flattened seeds, or immature whitish ones.

\section{BITTER ROOT.}

Apocynum androsæmifolium, Linn.

Syn.-Dogsbane, Milkweed.

N.O. Asclepiadacea.

Part used-Root.

Action-Emetic, cathartic, tonic, and diuretic. Being a cardiac stimulant it is of great value in cardiac 
dropsy in doses of 5 - 15 grains; as a general tonic in dyspepsia in powders of 4 grains three times a day. It is said to be useful in cases of chronic Bright's disease.

Preparations-Powdered root: Dose, 4-30 grains. Fluid extract : Dose, 10 to 30 drops.

Distinctive character-Root $\frac{1}{8}-\frac{1}{4}$ inch thick, with pale brown transversely wrinkled and cracked bark, half as thick as the white woody centre, and readily separating from it, with groups of stone cells in the outer bark. Taste, bitter and astringent.

The bark of Apocynum cannabinum is often sold for it, but has a yellowish wood, is longitudinally wrinkled, and has no groups of stone cells in the outer bark.

BITTERSWEET.

Solanum Dulcamara, Linn. N.O. Solanacea.

Syn.-Woody Nightshade, Violet Bloom, Scarlet Berry, Felonwood, Felonwort.

\section{Part used-Twigs.}

Action-Narcotic, resolvent, diuretic. Promotes all secretions and is used in rheumatism,obstinate cutaneous eruptions, scrofula, \&c. A decoction is made of ro drachms in 2 pints of boiling water, boiled down to I pint, and taken in doses of $\frac{1}{2}$ to 2 ounces with an equal quantity of milk.

Preparation-Fluid extract: Dose, $\frac{1}{2}-2$ drachms.

Distinctive character-The year-old greenish-brown shoots, which are the part used, are nearly cylindrical or indistinctly angular, about $\frac{1}{5}$ inch thick, slightly furrowed longitudinally, or sometimes warty, and usually cut into short pieces, internally hollow or partially filled with pith. The transverse section shows a green layer in the bark and a radiate ring of wood, or more than one ring in older stems. Taste, at first bitter 
(more so in the spring) and then sweet. Odour, unpleasant when fresh, but lost in drying.

Root bark thin, tough externally, blackish or blackish grey internally, pale brown, fibres of inner bark forming wide wedges. Taste, very astringent, slightly bitter. Odour, none.

\section{BLACKBERRY.}

Syn.-Bramble.

Parts used-Root, leaves.

Action-Astringent, tonic. A valuable remedy for diarrhœa, dysentery, \&c. A preparation called Blackberry Cordial contains the properties named above combined with aromatics. The root is the most astringent. The infusion of $I$ ounce of root or leaves to a pint of water is taken in wineglassful doses.

Preparations-Fluid extract: Dose, $\frac{1}{2}-I$ drachm. Fluid extract, root, U.S.P.: Dose, I5 drops. Syrup U.S.P.: Dose, I drachm.

The root bark of $R$. trivialis, Michx., and $R$. Canadensis, Linn., are also used in the United States of America, and the leaves of $R$. fruticosus, Sm., in Europe.

\section{BLACK CURRANT.}

Ribes nigrum, Linn.

Part used-Leaves.

N.O. Saxifragacea.

Action-Diuretic, refrigerant, detergent. Very useful in febrile and inflammatory diseases, in hoarseness and affections of the throat. The infusion of $I$ ounce in a pint of boiling water is taken in teacupful doses. The fresh fruit is used for jams, jellies, \&c., and forms an excellent basis for medicated lozenges.

Distinctive character-Leaves palmate, stalked, with scattered yellow glands on the under surface, about 2 inches in diameter with three to five pointed, serrate, angular lobes. Odour, characteristic. 
BLACK HAW.

Viburnum prunifolium, Linn.

(And other species.) N.O. Caprifoliacea.

Syn.-Stagbush, American Sloe.

Part used-Bark of root.

Action-Uterine tonic, sedative, nervine, anti-spasmodic. Largely used for preventing miscarriage, in which cases it should be given four or five weeks previous to the expected event. It checks pains and bleeding, and is an excellent remedy for dysmenorrhœa and the after pains of childbirth. The infusion of I ounce to a pint of boiling water is taken in tablespoonful doses.

Preparations-Powdered bark: Dose, $\frac{1}{2}-\mathrm{I}$ drachm. Fluid extract: Dose, $\frac{1}{2}-\mathrm{I}$ drachm. Solid extract (alc.): Dose, 2-4 grains.

Distinctive character-Young bark in thin quilled pieces, glossy purplish brown with scattered warts. Old bark greyish brown, inner surface white and smooth, the thin corky layer easily separable from the green layer. Fracture short. Taste, astringent and bitter. Odour, slightly valerianic. The root bark is cinnamon-coloured and very bitter.

The bark of a species of Acer is sometimes substituted for this bark.

BLACK ROOT.

Leptandra Virginica, Nutt. N.O. Scrophulariacea.

Syn.-Culver's Root, Culver's Physic, Physic Root, Veronica Virginica, L.

Part used-Root.

Action-Cathartic, diaphoretic, tonic, antiseptic. Used principally for its cathartic effect as it acts with certainty and without griping. In fevers it is invaluable as a cathartic, purifying the blood and removing all morbid obstructions in a mild natural manner. It is said to act especially on the intestines and therefore 
valuable in chronic constipation and intestinal indigestion. May be advantageously combined with other medicines.

Preparations-Fluid extract: Dose, $\frac{1}{2}-I$ drachm. Leptandrin: Dose, $\frac{1}{4-2}$ grains. Powdered extract U.S.P.: Dose, 4 grains. Solid extract (alc.): Dose, 5-10 grains.

Distinctive character-Rhizome about inch in diameter, showing stem bases at intervals of $\frac{1}{2}-\mathrm{I} \frac{1}{2}$ inch, blackish brown, with transverse scars in rings $\frac{1}{8}-\frac{1}{4}$ inch apart, and chiefly on the lower surface. Rootlets wiry, brittle, having a short horny fracture and a white, woody, central cord. Taste, bitterish.

BLADDERIVRACK.

Fucus vesiculosus, Linn. N.O. Alga.

Syn.-Bladder Fucus, Seawrack, Kelpware, Seaweed. Part used-Plant.

Action-Deobstruent, antifat. Has been employed with success in obesity. The infusion of $\mathbf{I}$ ounce to a pint of boiled water is taken in wineglassful doses, or better in pill form. It influences the kidneys and acts as an alterative.

Preparations-Fluid extract: Dose, $\frac{1}{2}-4$ drachms. Solid extract: Dose, 15-30 grains. The doses should be gradually increased.

Distinctive character-Frond flat, forked, blackish, about $\frac{1}{2}$ inch broad and I or 2 feet long, with a distinct midrib and oval bladders, usually in pairs. Taste, mucilaginous and saline. Odour, like seaweed.

\section{BLOOD ROOT.}

\section{Part used-Root.}

Sanguinaria Canadensis, Linn. N.O. Papaveracea.

Action-Stimulant, tonic, expectorant. Of great value in chest diseases, bleeding of the lungs, pneumonia, 
chronic bronchitis, \&c. In whooping cough and croup it acts advantageously, and should be given until vomiting results. As an external remedy the powdered root or tincture acts energetically in cases of fungoid tumours, ringworm, \&c. In polypus of the nose it should be used as a snuff. Large doses will produce narcotic effects.

Preparations-Powdered root: Dose, I0-30 grains. Tincture: Dose, $\frac{1}{2}-2$ drachms. Tincture U.S.P.: Dose, I5 drops. Fluid extract: Dose, I0-30 drops. Solid extract (alc.): Dose, 5-8 grains. Sanguinarin: Dose, $\frac{1}{4}$-I grain.

Distinctive character-The rhizome is usually about 2 or more inches long and nearly $\frac{1}{2}$ inch in diameter, reddish brown, and longitudinally wrinkled. Fracture short, transverse section whitish, with numerous small red resin cells, or sometimes wholly suffused with red. Taste, bitter and acrid. Odour, heavy.

BLUE FLAG.

Iris versicolor, Linn. N.O. Iridacea.

Syn.-Water Flag, Poison Flag, Flag Lily, Liver Lily, Snake Lily.

\section{Part used-Root.}

Action-Alterative, antisyphilitic, diuretic, cathartic, stimulant. This is chiefly used for its alterative properties, and enters into many compounds for purifying the blood and for venereal affections. It is also valuable in liver complaints, fluor albus, and dropsy.

Preparations-Powdered root: Dose, 20 grains as a cathartic. Fluid extract: Dose, $\frac{1}{2}-I$ drachm. Solid extract: Dose, IO-I5 grains. Tincture: Dose, I-3 drachms. Irisin: Dose, I-3 grains.

Distinctive character-Rhizome with annual joints 2 or more inches long, about $\frac{3}{4}$ inch in diameter, cylindrical, becoming compressed towards the larger end 
where the cup-shaped stem scar is seen, with numerous rings formed of leaf scars above, and with scars of rootlets below. Fracture short, brownish, the vascular bundles scattered through the central column. Taste, acrid and nauseous. Odour, none.

BLUE MALLOW.

Syn.-Common Mallow.

Parts used-Flowers, herb.

Action-Demulcent, mucilaginous, pectoral. The infusion is a popular cure for coughs, colds, \&c.

Preparation-Fluid extract: Dose, $\frac{1}{2}-2$ drachms.

Distinctive character-Leavesstalked, roundish, five to seven-lobed, hairy with stellate hairs, veins prominent below. Flowers mauve-coloured, with dark veins. Calyx with three separate outer bracts. Fruit manycelled, disciform, each cell one-seeded. Taste, mucilaginous. Odour, none.

BOLDO.

Peumus Boldus, Molina. N.O. Monimiacee.

Syn.-Boldu, Boldea fragrans, C. Gay.

Part used-Leaves.

Action-Tonic, stimulant, antiseptic. Used chiefly in chronic hepatic torpor and dyspepsia. Is also given in catarrh of the bladder, gonorrhoa, \&c. The virtues of the drug seem to be due to an essential oil.

Preparation-Fluid extract: Dose, $\frac{1}{6}-\frac{1}{2}$ drachm.

Distinctive character-Leaves oval, shortly stalked, rather thick, rigid and brittle, recurved at the margin, about 2 inches long and $1 \frac{1}{4}$ inch wide, rough with points bearing stellate hairs. Taste, slightly lemony. Odour, recalling lemon and coriander. 
Syn.-Thoroughwort, Indian Sage.

\section{Part used-Herb.}

Action-Diaphoretic, tonic, febrifuge, expectorant, laxative. Will be found a certain remedy in all cases of fever. In many cases no other medicine will be needed if given in moderate doses frequently. It is largely used by the negroes in the Southern States for this purpose as well as for its tonic effects. Also recommended in catarrh and skin diseases. An infusion of I ounce to I pint of boiling water may be taken in wineglassful doses, hot or cold. For colds and to produce perspiration it should be given hot, and as a tonic, cold.

Preparations-Powdered herb: Dose, 12-20 grains. Fluid extract : $\frac{1}{2}-1 \mathrm{drachm}$. Solid extract : Dose, 5-10 grains. Eupatorin: Dose, I-3 grains.

Distinctive character-Leaves opposite, 4-6 inches long, lanceolate, tapering above to a narrow point, united at their base, crenate at margin, reticula ted above, with minute, shining, yellow resin dots beneath. Taste, astringent and persistently bitter. Flavour, slightly aromatic.

BORAGE.

Syn.-Burrage.

\section{Part used-Leaves.}

Action-Diuretic, demulcent, emollient. Used in France for fevers and pulmonary complaints. For internal use an infusion is made of $I$ ounce of leaves to a pint of boiling water and taken in wineglassful doses. 
Externally employed as a poultice for inflammatory swellings.

Preparation-Fluid extract: Dose, $\frac{1}{2}-\mathrm{I}$ drachm.

Distinctive character-Leaves oval, pointed, 3 or more inches long, and about $\mathrm{I} \frac{1}{2}$ inch broad, the lower stalked, rough, with stiff one-celled hairs on the upper surface and on the veins below, the margin entire but wavy. Flowers blue, star-shaped, with central appendages, the anthers forming a cone in the centre. Fruit of four brownish black nutlets, hollowed at base. Taste of leaves, cucumber-like and saline. Odour, none.

BOXWOOD.

Cornus florida, Linn. N.O. Connacea.

Syn.-American Dogwood, Dogtree.

Parts used-Bark, rootbark.

Action-Tonic, astringent, stimulant. Used with advantage in all fevers, and forms an excellent substitute for Peruvian Bark, also given for headaches and exhaustion. A decoction of I ounce of bark in a pint of water is taken in wineglassful doses.

Preparations-Powdered bark: Dose, $\frac{1}{3} \cdot 1$ drachm. Fluid extract: Dose, $\frac{1}{2} \cdot 1$ drachm. Cornin : Dose, 2 grains.

Distinctive character-Bark in slightly curved pieces averaging about 2 inches long and $\frac{1}{2}$-I inch wide, greyish and scaly, or, where the outer layer is removed, pale brown and irregularly cracked longitudinally; inner surface pinkish brown, rough, with minute linear prominences. Transverse fracture with somewhat distant medullary rays and raised groups of stone cells. Taste, astringent, bitter. Odour, none. 
BROOKLIME.

Syn.-Water Pimpernel.
Veronica Beccabunga, Linn. N.O. Scrophulariacea.

\section{Part used-Herb.}

Action-Alterative, diuretic. Is given in scurvy, impurity of blood, \&c. An infusion of the leaves of I ounce to I pint of boiling water is taken in wineglassful deses frequently.

Distinctive character-Leaves oval, obtuse, stalked, crenate-serrate, opposite, not hairy. Flowers blue, with two stamens, on short, axillary, loose racemes. Fruit two-celled, notched at the apex, roundish. Taste, bitter, slightly acrid. Odour, none.

BROOM.

Cytisus scoparius, Link. N.O. Leguminose.

Syn.-Broomtops, Irish Broom. Spartium scoparinm, Linn.

Part used-Tops.

Action-Diuretic, cathartic. Used with advantage in dropsy. The dose of the infusion of $\mathrm{I}$ ounce to a pint of boiling water is a wineglassful taken frequently.

Preparations-Fluid extract: Dose, $\frac{1}{2}-1$ drachm. Juice B.P.: Dose, I-2 drachms. Infusion B.P.: Dose, I-2 ounces.

Distinctive character-Stem angular, five-sided, slightly winged, dark green, branching at an acute angle, $\frac{1}{18}-\frac{1}{8}$ inch in diameter. Pods flat, blackish, $\mathrm{I} \frac{1}{2}$ inch long and $\frac{1}{4}$ inch wide. Flowers yellow, brown when dry, papilionaceous. Taste, bitterish, unpleasant. Odour, none. 
BROOM-CORN.

Sorghum vulgare, Pers.

N.O. Graminacea.

Syn.--Sorghum Seeds, Sorghum saccharatım, Moench.

Part used-Seeds.

Action-Diuretic, demulcent. The American negroes make a decoction of 2 ounces of seeds with a quart of water, boiled down to a pint, and take this as a remedy for urinary, bladder, and kidney complaints. This drug is entirely different from Broom (Cytisus scoparius) and should not be confounded with it.

Distinctive character-Seeds usually white, known in England as Darri, or Durra, about $\frac{1}{8}$ inch in diameter, rounded, slightly compressed, white and starchy within.

BRYONY, BLACK.

Syn.-Blackeye Root.

Part used-Root.

Action-Rubefacient, diuretic. The fresh root is scraped and the pulp rubbed into parts affected by gout, rheumatism, or paralysis. It is also reputed as a diuretic. Black Bryony is a popular remedy for removing discolouration caused by bruises, hence its nameBlackeye Root.

\section{Preparation-Tincture: $\mathrm{x} \cdot 5 \mathrm{~min}$.}

Distinctive character-Root nearly cylindrical, I- I $\frac{1}{2}$ inch in diameter, 3.4 inches long, or more, with scattered wiry rootlets, blackish brown externally, whitish within. Usually sold fresh, and, when scraped, yielding a slimy paste. Taste, acrid. Odour, slightly earthy. 
Syn,-Bryonia, English Mandrake, Wild Bryony.

Part used-Root.

Action-Irritating, hydragogue, cathartic. Useful in small doses for cough, influenza, bronchitis, pneumonia, \&c. Valuable in cardiac disorders caused by rheumatism and gout, also in malarial and zymotic diseases. Large doses should be avoided.

Preparations-Fluid extract: Dose, $\frac{1}{8}-\mathrm{I}$ drachm. Bryonin: Dose, $\frac{1}{4}-2$ grains.

Distinctive character-Root very large, I-2 feet long or more, branched, I-3 inches in diameter, white both externally and internally. Usually sold dry, in circular slices $\frac{1}{4-\frac{1}{3}}$ inch thick. Transverse section showing concentric rings and radiating lines of porous vascular bundles. Taste, acrid and bitter. Odour, none.

Offered by gardeners as Mandrake root (see Podophyllum).

The Bryonia alba, Linn., used by Homœopaths, which is not wild in England, has globular black berries. Bryonia dioica, Jacq., has globular red berries. Both are climbing plants with palmate rough leaves and small greenish white unisexual flowers.

BUCHU.

Barosma betulina, Bart. and Wendl. N.O. Rutaced.

Syn.-Diosma betulina, Thunb.

Part used-Leaves.

Action-Diuretic, diaphoretic, stimulant. It exerts a direct effect on the urinary organs, in all affections of whicl it will be found beneficial. In gravel, inflammation, and catarrh of the bladder it is specially useful. The infusion (B.P.) of I ounce of leaves to a pint of 
boiling water is taken in wineglassful doses three or four times a day.

Preparations-Fluid extract: Dose, $\frac{1}{2}-\mathrm{I}$ drachm. Infusion B.P.: Dose, $\mathrm{I}-2$ ounces. Tincture B.P.: Dose, $\frac{1}{8}$-I drachm. Solid extract: Dose, 5 -I 5 grains. Barosmin: Dose, 2-3 grains.

Distinctive character-Leaves $\frac{1}{2}-\frac{3}{4}$ inch long and $\frac{8}{10}-\frac{5}{10}$ inch wide, leathery and glossy, obovate, with recurved tip and toothed margin, and round oil glands scattered through the leaf. Taste and odour, characteristic.

Buchu leaves are often adulterated with other leaves.

BUCKBEAN.

Syn.-Bogbean, Marsh Trefoil.

Part used-Herb.

Actiun-Tonic, deobstruent. A splendid bitter tonic, which will render great service in cases of rheumatism, scurvy, and skin diseases. The infusion of $\mathrm{I}$ ounce to a pint of boiling water is taken in wineglassful doses frequently repeated.

Preparation-Fluid extract: Dose, 10-40 drops.

Distinctive character-Leaves thin, brittle, with long stalks and three obovate leaffets which are about 2 inches long and I broad, and entire at the margin. Taste, very bitter. Odour, none.

BUCKTHORN.

Rhamnus cathartica, Linn. N.O. Rhamnacea.

Syn.-Buckthorn Berries. Bacca Spina-cervina.

Distinctive character-The berries are used for expressing the juice, with which syrup of Buckthorn is made. When fresh they are globular, about $\frac{1}{3}$ inch in diameter, with the remains of a calyx beneath; 
they contain four deeply-grooved seeds, each enclosed in a parchment-like endocarp. The juice, at first greenish, becomes purplish brown on keeping. Taste, bitter and acrid.

BUCKTHORN, ALDER. Rhamnus Frangula, Linn.

Part used-Bark. N.O. Rhannacea.

Action-Tonic, laxative, cathartic. The dried seasoned bark, from one to two years old, should only be used, as the freshly-cut bark causes violent griping pains, emesis, and nausea. It is chiefly used as a remedy for chronic constipation, in small doses repeated three to four times daily. The decoction of I ounce of bark in a quart of water boiled down to a pint is taken in tablespoonful doses.

Preparation-Fluid extract: Dose, $\frac{1}{2}-2$ drachms.

Distinctive character-Bark in thin quilled pieces, greenish black externally, with numerous elongated whitish transverse marks (lenticels). When abraded with the nail or a knife a crimson layer appears beneath the epidermis. Inner surface brownish yellow. Fracture fibrous. Taste, sweetish, then bitter. Odour, none.

\section{BUGLE.}

Ajuga reptans, Linn.

Syn.-Bugula, Common Bugle.

N.O. Labiata.

Part used-Herb.

Action-Bitter, astringent, aromatic. Has been employed in hæmorrhages, biliary disorders, and consumption.

Dose of Infusion (I ounce to I pint), a wineglassful frequently.

Distinctive character-Stem smooth on two sides, downy on the other two, leaves opposite, oblong-obovate 
and obtuse, slightly toothed or almost entire at the margin, having many-celled hairs on both surfaces, with nearly sessile glands. Flowers with stamens projecting, the upper lip being very short, bracts purplish. Taste, slightly aromatic and bitter. Odour, imperceptible.

BUGLEWEED.

Lycopus Virginicus, Linn. N.O. Labiatc.

Syn.-Sweet Bugle, Water Bugle, Gipsy Weed.

Part used-Herb.

Action-Sedative, astringent, and mild narcotic. Used in coughs, bleeding from lungs, and consumption. The infusion of $\mathrm{I} O z$. to I pint of boiling water is taken in wineglassful doses frequently.

Preparations-Fluid extract: Dose, 10-30 drops. Lycopin: Dose, I-4 grains.

Distinctive character-Stem smooth, obtusely quadrangular. Leaves opposite, not hairy, short-stalked, elliptic-lanceolate, and toothed above, but entire and wedge-shaped at the base, gland-dotted beneath. Flowers in axillary clusters, calyx with four ovate obtuse teeth. Corolla four-lobed, purplish, with only two fertile"stamens. Taste, bitter and slightly aromatic. Odour, mint-like.

BUGLOSS.

Echium vulgare, Linn. N.O. Boraginacea.

Syn.-Viper's Bugloss, Blueweed.

Part used-Herb.

Action-Diuretic, demulcent, expectorant. It relieves inflammatory pains, and is used in fevers and nervous complaints. The infusion of $\mathrm{r}$ ounce in a pint of boiling 
water is given in wineglassful to teacupful doses as required.

Distinctive character-Stems I-2 feet high, with alternate leaves, both harsh, with rigid, bulbous hairs. Leaves linear lanceolate, often undulated. Flowers in curved clusters, irregularly tubular, funnel-shaped, blue. Fruit of four small seed-like pyrenes. Taste, mucilaginous. Odour, none.

The common Bugloss, Lycopsis arvensis, Linn., has small wheel-shaped blue flowers and wavy toothed leaves which have also rigid hairs with a bulbous base.

\section{BURDOCK.}

Syn.-Lappa, Lappa minor, Hill.

Arctium Lappa, Linn. N.O. Composita.

Parts used-Root, herb, seeds (fruits).

Action-Alterative, diuretic, and diaphoretic. It is one of the finest blood purifiers in the herbal system, and should be used in all such cases alone or in conjunction with other remedies. Both root and seed may be taken as a decoction of I ounce to a pint and a half of water, boiled down to I pint, in doses of a wineglassful three or four times a day.

Preparations-Fluid extract root: Dose, $\frac{1}{2}-2$ drachms. Solid extract: Dose, 5-I5 grains. Fluid extract, seed: Dose, 10-30 drops.

Distinctive character-The root is usually cut up into pieces an inch or more long and about $\frac{3}{4}$ inch in thickness, brownish grey externally, shrunken and furrowed longitudinally, and whitish internally. The fracture is short and the transverse surface shows a thick bark about a quarter of the diameter of the root, and a central cylinder with a radiate structure, sometimes with cavities containing white remains of tissue. Taste, sweetish and mucilaginous.

Fruits, erroneously called seeds, brownish grey, wrinkled, about inch long and $\frac{1}{16}$ inch in diameter. 
The leaves are large, rhubarb-like in shape, whitish beneath. Flowerheads globular, with hooked scalelike bracts.

\section{BURNET, GREATER.}

Sanguisorba officinalis, Linn. N.O. Rosacea.

Syn.-Garden Burnet.

Part used-Herb.

Action-Astringent, tonic. Useful in hæmorrhages.

Distinctive character-Leaves pinnate, with about 13 opposite leaflets, rounded at the ends and sharply serrate, the teeth with slender thickened margins. Flowerheads purplish, oblong. Flowers with fourtoothed membranous calyx. Taste, astringent. Odour, none.

\section{BURNET SAXIFRAGE.}

Pimpinella Saxifraga, Linn. N.O. Umbellifera.

Syn.-Lesser Burnet, Salad Burnet.

Parts used-Root, herb.

Action-Aromatic, carminative, stomachic.

Distinctive character-Root spindle-shaped, brownish, about 8 inches long, often crowned with several hollow stem bases, ringed above, and longitudinally wrinkled and tuberculated below. Fracture short and whitish. Bark thick, with resinous dots in radiating lines, central woody cylinder porous and radiate. Leaves pinnate, with oval serrate leaflets, nearly smooth or slightly hairy below. Flowers in globular heads with hard quadrangular calyx tube with netted veins. Taste, cucumber-like. Odour, none. 


\section{BURRA GOKEROO.}

Syn.-Barra Gokhru.

\section{Part used-Seeds.}

Action-Antispasmodic, demulcent, diuretic. Has been used in incontinence of urine, in gonorrhœa, gleet, and irritation of urinary organs. An infusion ( $I$ in 20) should be taken each day in several doses.

Distinctive character-Fruits pale brown, calyx $\frac{1}{10}$ th inch long and $\frac{1}{1}$ inch in diameter at the base, with four angular ridges having a short straight spine at the base of each, two-celled with four narrow elongated seeds. Taste, mucilaginous. Odour, none.

\section{BUTCHER'S BROOM. Ruscus aculeatus, Linn. N.O. Liliacea.}

Syn.-Common Butcher's Broom, Kneeholm, Kneeholy, Pettigree, Sweet Broom.

\section{Part used-Root.}

Action-Diaphoretic, diuretic, deobstruent, aperient. Will be found of use in jaundice, gravel, and female obstructions. The decoction is the usual form of administration.

Distinctive character-The rhizome is brownish grey, $2-4$ inches long and $\frac{1}{3}$ inch in diameter, with rather crowded rings and rounded stem scars on the upper surface, and many woody rootlets below. The transverse section shows a number of vascular bundles in the central portion. Taste, sweetish, slightly acrid and turpentiny. Odour, none.

BUTTERBUR.

Petasites vulgaris, Desf. N.O. Composita. Syn.-Common Butterbur, Tussilago Petasites, Linn. Part used-Root.

Action-Cardiac tonic, stimulant, diuretic. Has been in use as a remedy in fevers, asthma, colds, and 
urinary complaints, gravel, \&c. The decoction is taken warm in wineglassful doses frequently repeated.

Distinctive character-The rhizome occurs in pieces 2.4 inches long, and about $\frac{1}{4}$ inch in diameter, of a reddish brown or purplish brown colour, furrowed longitudinally, ringed with transverse scars at intervals of about $\frac{1}{2}$ inch. The transverse section shows a thin, dark, horny bark containing dark oil cells and a narrow ring of woody tissue surrounding a large, hard pith. Fracture short. Taste, bitterish. Odour, none.

BUTTERNUT.

Syn.-White Walnut, Oilnut.

Part used-Bark.

Action-Cathartic, tonic, vermifuge. A gentle purgative, which does not bind after operating. Is also a remedy for worms, especially in children. The solid extract is generally used either in pills or syrup. Four or five pills should be taken at night or a tablespoonful of syrup twice a day. The syrup is made by using $\frac{1}{2}$ ounce of extract to 8 ounces of simple syrup, beating them well together in a mortar.

Preparations-Fluid extract: Dose, I to 2 drachms. Solid extract: Dose, 5 to Io grains. Juglandin: Dose, 2.5 grains.

Distinctive character-The inner bark, which is the part used, occurs in flat or curved pieces, $\frac{1}{8}-\frac{1}{4}$ inch thick, but varying in length; it usually has the ends cut off obliquely. Fracture short, having a checkered appearance due to the brown fibres alternating with the white medullary rays and white cellular tissue. Taste, bitter and slightly acrid. Odour; feeble.

BUTTON SNAKEROOT.

Part used-Root.

Liatris spicata, Willd. N.O. Composita.

Action-Diuretic, stimulant. It acts kindly on the stomach, and is of value in kidney diseases. Said to be 
beneficial in Bright's disease, and is used in conjunction with Unicorn Root in menstrual diseases. The decoction is very efficacious in gonorrhœa, gleet, \&c. Taken in wineglassful doses three to four times daily.

Distinctive character-Rhizome $\frac{1}{2}$ inch or more in diameter, somewhat tuberculate, with several cupshaped scars. Externally, brownish and slightly wrinkled; internally, whitish, speckled with dark grey dots, very tough. Taste, bitterish, faintly aromatic, somewhat resembling cedar.

CABBAGE TREE.

Andira inermis, H. B.\&. K.

N.O. Legzminosa.

Syn.-Geoffraya inermis, S.W. Jamaica Cabbage Tree, Yellow Cabbage Tree, Worm Bark.

Part used-Bark.

Action-Febrifuge, cathartic, vermifuge. Has proved an effectual anthelmintic. The infusion of $I$ ounce in a pint of water may be taken in tablespoonful doses three to four times a day. Any unpleasant action may be obviated by Castor Oil, Lemon Juice or Warm Water.

Preparation-Fluid extract: Dose, $\frac{1}{\frac{1}{4}-\mathrm{I}}$ drachm.

Distinctive character-In long flat pieces $\frac{7}{8}$ inch thick, greyish white and fissured externally, inner surface brownish and striated. Fracture laminated with yellow fibres. Taste, mucilaginous, bitter. Odour, slight but disagreeable.

CACAO.

Theobroma Cacao, Linn. N.O. Sterculiacea.

Syn.-Cocoa, Chocolate Tree.

Part used-Seeds.

Action-Nutritive, stimulant, diuretic. In the household, cocoa as well as chocolate is a well-known nutri- 
tive beverage. These preparations are however seldom used as medicine, although chocolate is an agreeable and convenient base for lozenges of nauseous or bitter drugs, such as Calomel, Santonin, \&c. The cocoabutter, expressed from the seeds, forms a hard, bland article, melting at a comparatively low temperature, and is much used in suppositories, lip salves, pomades, \&c. Another constituent of the seeds is Theobromine, which resembles Caffeine in its stimulant and diuretic action.

Distinctive character-Seeds oval, oblong compressed, $\frac{8}{5}$ of an inch or more long, husk thin and papery. Seed breaking up into angular fragments under pressure, due to the presence of the inner seed coat between the folds of the cotyledons. Taste and odour well known.

CAJUPUT. Melaleuca Leucadendron, Linn. N.O. Myrtacea.

Syn.-Cajeput, White Tea-Tree, Swamp Tea-Tree, Broad-leaved Tea-Tree, White-Wood, Melalenca Cajuputi, Roxb.

\section{Part used-Oil.}

Action-Stimulant, antispasmodic, diaphoretic. The natives of the Molucca Islands, where the tree grows, esteem it very highly as a remedy for all kinds of pains, internal and external. It may be employed with advantage in lotions for rheumatic affections, toothache, neuralgia, sprains, and bruises. Internally, it may be taken on sugar in doses of I-Io drops as a valuable diffusive stimulant in colics, spasms, flatulence, and hiccough.

Preparations-Liniment of Croton Oil B.P., Spirit B.P.: Dose, 5-20 drops.

Distinctive character-The oil has usually a greenish colour and an odour recalling that of Camphor and Eucalyptus. 
CALABAR BEAN. Physostigma venenosum, Balf. Syn.-Ordeal Bean, Chopnut. N.O. Leguminosa.

Part used--Seeds.

Action-Sedative, myotic. It allays extreme nervous irritation, but should be given with great care, and only under legal medical advice, as large doses have a poisonous effect. Mostly used in combination with Prickly Ash or Belladonna. Its chief use is in eye diseases as a local myotic.

Preparations-Fluid extract : Dose, I-3 drops. Solid extract B.P.: Dose, $\frac{1}{4}-1$ grain. Alkaloid Physostigmine B.P.: Dose, $\frac{1}{60}-\frac{x}{20}$ grain. Tincture U.S.P.: Dose, 15 drops.

Distinctive character-Seeds dark brownish or blackish brown, I-I $\frac{1}{4}$ inch long, $\frac{5}{8}$ inch broad, I $\frac{1}{2}$ inch thick, oblong with rounded ends, or slightly kidneyshaped, the hilum extending along the whole convex side. Cotyledons white, turning yellow when touched with strong Potash solution. Porson.

CALAMINT.

Calamintha officinalis, Moench. N.O. Labiate.

Syn.-Common Calamint, Basil Thyme, Calamintha menthifolia, Host., Mountain Mint.

Part used-Herb.

Action-Diaphoretic, expectorant.

Distinctive character-Leaves broadly ovate, slightly serrate, stalked. Flowers pale purple. Calyx with upper teeth triangular, erect, fringed with hairs, lower teeth longer, awl-shaped. Taste, aromatic. Odour, mint-like.

CALAMUS.

Acorus Calanius, Linn. N.O. Aracere.

Syn.-Sweet Flag, Calamus aromaticus.

Part used-Root.

Action-Aromatic, carminative, and stomachic. Useful in flatulence, wind, colic, ague, and dyspepsia, \&c. 
Is often added to tonic medicines. The root may be chewed in dyspepsia, or an infusion of $\mathrm{I}$ ounce to a pint of boiling water may be taken freely in doses of a teacupful.

Preparation-Fluid extract U.S.P.: Dose, I5-60 àrops.

Distinctive character-Rhizome about $\frac{3}{4}$ inch in diameter, pale fawn-coloured longitudinally, wrinkled, with numerous oblique transverse leaf scars above, crowded in the part near the stem with small circular root scars underneath. Fracture whitish, short, and finely porous, with scattered woody bundles visible when the section is wetted. Taste, aromatic, pungent, and bitter. Odour, sweet and aromatic. The peeled rhizome is usually angular and often split, and is less aromatic.

CALOTROPIS.

Calotropis procera, R.Br. N.O. Asclepiadacea.

Syn.-Mudar Bark, Asclepias proceva, Willd.

Distinctive character-The bark occurs in irregular short pieces, slightly quilled or curved, and from $\frac{1}{8}-\frac{1}{5}$ inch thick, and $\frac{3}{4}$ inch or more in width. Externally, greyish yellow, soft and spongy; internally, yellowish white and smooth, or finely striated. Fracture short, yellowish white. Taste, acrid and bitter.

CALISAYA.

Cinchona Calisaya. Wedd. N.O. Rubiacea.

Syn.-Yellow Cinchona, Cinchona flava, China regia. Part used-Bark.

Action-Stimulant, tonic, antiperiodic. For medicinal uses see Peruvian Bark.

Distinctive character-Bark in quilled pieces about $\frac{1}{2}-\mathrm{I}$ inch in diameter, outer surface grey with many darker lines and longitudinal fissures, and a few transverse fissures, outer layer peeling off in places. 
Fracture, minutely fibrous; the fibres are seen to be very short when the transverse surface is abraded by the finger nail. Taste, bitter. Odour, very slight.

CALUMBA.

Syn.-Cocculus palmatus, D. C., Colombo.

Part used-Root.

Action-Tonic, febrifuge. A bitter tonic without astringency. Valuable in all cases of dyspepsia, weakness of stomach, \&c. An infusion of $r$ ounce in a pint of cold water may be taken in 2 tablespoonful doses three to four times a day.

The U.S. Dispensatory gives the following as a remedy for accumulation of flatus in the bowels:- $\frac{1}{2}$ ounce each powdered Calumba and Ginger, I drachm Senna. Infuse in I pint boiling water. Dose, a wineglassful three times a day.

Preparations-Powdered root: Dose, ro-I 5 grains. Fluid extract: Dose, 10-30 drops. Infusion B.P.: Dose, $\frac{1}{3}-1$ oz. Tincture B.P. and U.S.P.: Dose, $\frac{1}{2}-\mathrm{I}$ drachm. Solid extract: Dose, 2 grains. Powder extract : Dose, 2 grains. Conc. Solut. B.P.: Dose, $\frac{1}{2}-1$ drachm.

Distinctive character-Root in circular sections about $1 \frac{1}{2}-2 \frac{1}{2}$ inches in diameter and $\frac{1}{4}$ inch or more in thickness, the centre usually depressed. Bark thick, outer surface greyish brown, transverse section yellowish, rather darker in the bark, vascular bundles in radiating lines. Fracture short and mealy. Taste, mucilaginous, very bitter. Odour, slight.

\section{CAMPHOR.}

Cinnamomum Camphora, T. Nees and Eberm. N.O. Lauracere.

Syn.-Gum Camphor, Laurel Camphor, Laurus Camphora, Linn., Camphora oficinarum, Nees.

Action-Sedative, anodyne, antispasmodic, diaphoretic, anthelmintic. Internally, Camphor is used in 
colds, chills, and in diarrhœa from colds. In all Inflammatory affections, fevers and hysterical complaints, it will be found of great value. It acts beneficially in gout, rheumatic pains and neuralgia, and is highly valued in all irritations of the sexual organs. Large doses should be carefully avoided as they cause vomiting, palpitation, and convulsions. Externally, it can be safely applied in all cases of inflammations, bruises, sprains, \&c.

Preparations-Camphor Water B.P.: Dose, I-2 ounces. Liniment of Aconite B.P. Liniment of Belladonna B.P. Liniment of Camphor B.P. Liniment of Camphor comp. B.P. Liniment of Opium B.P. Liniment of Soap B.P. Liniment of Mustard B.P. Liniment of Turpentine B.P. Liniment of Turpentine and Acetic Acid B.P. Spirit of Camphor B.P.: Dose, 5-20 drops. Tincture of Camphor comp. (Paregoric) B.P.: Dose, $\frac{1}{2}-I$ drachm. Water B.P.: $\frac{1}{2}-I$ fluid ounce.

Distinctive character-Whitish, slightly opaque, with a strong odour, volatilises towards the light in glass bottles. Obtainable in commerce in quadrangular tablets of definite weight, or in minutely crystalline powder (Flowers of Camphor). Soluble readily in spirits of wine, to a less extent in warmed fixed oils, and in water sufficiently to flavour it strongly. Floats on water.

CANADIAN HEMP. Apocynum cannabinum, Linn. N.O. Lauracea. Syn.-Black Indian Hemp, Apocymum pubescens. R.Br. Part used-Root.

Action-Diaphoretic, diuretic, expectorant, emetic. Valuable incardiac dropsy, and recommended favourably in intermittent and remittent fevers. Is also used in amenorrhœea and leucorrhcea. A decoction of I ounce 
in a pint of water is taken in tablespoonful doses or more. As an emetic give 10.30 grains of Powdered Root.

Preparations-Fluid extract: Dose, 5 drops to $\frac{1}{2}$ drachm. Apocynin: Dose, $\frac{1}{2}-I$ grain.

Distinctive character-Root $\frac{1}{4}$ inch or more in diameter, rarely branched, longitudinally wrinkled, sometimes fissured transversely, pale brown externally. Bark thick, whitish, with central porous radiate wood, and often a small central pith. Fracture short. Taste of the bark, permanently bitter, disagreeable. Odour, none.

CANCHALAGUA.

\section{Part used-Herb.}

Action-Bitter, tonic, stimulant. An excellent general tonic and stimulant. May be used in dyspepsia and all complaints of digestion. The infusion of $\mathrm{r}$ ounce to a pint of boiling water is taken in wineglassful doses.

Preparation-Fluid extract: Dose, $\frac{1}{2}$-I drachm.

Distinctive character-Closely resembles Centaury, but is more branched and has linear leaves and distinctly stalked flowers.

CANELLA.

Syn.-White Cinnamon.

Part used-Bark.

Action-Aromatic, stimulant, tonic. Useful in enfeebled conditions of the stomach and intestines. Gener- 
ally given in combination with other stomachics. Dose, ro-40 grains.

Preparation-Pulv. Aloes cum Canella (Hiera Picra): Dose, 1 -I drachm.

Distinctive character-Bark fawn-coloured externally, chalky white on inner surface, in quilled pieces $\frac{1}{4}$ to $\mathrm{I} \frac{1}{2}$ inches in diameter. Transverse fracture short, whitish with numerous bright orange-yellow dots composed of resin cells. Taste, biting, aromatic, slightly recalling that of cinnamon. Odour, aromatic.

CARAWAY.

Carum Carvi, Linn. N.O. Umbellifera.

Syn. -Caraway "Seed," Caraway Fruit.

Part used-Fruit.

Action-Carminative, stimulant. Used in children's ailments, flatulence and stomachic derangements, also for flavouring in medicine and as a culinary.

Preparations-Fluid extract: Dose, 5-30 drops. Oil B.P.: Dose $\frac{1}{2}-3$ drops. Water B.P.: Dose I-2 ounces. Confection of Pepper B.P.

Distinctive character-The fruit, wrongly called seed, is too well known in Abernethy biscuits to need description. The quality varies, English caraways are brighter brown and cleaner, and are the best. Dutch are darker coloured, Mogador are light brown, but longer. The fruit should be free from stalks and dirt.

CARDAMOMS.

Elettaria Cardamomum, Maton. N.O. Zingiberacea. Syn,-Cardamom Seeds, Malabar Cardamoms.

Part used-Seeds.

Action-Carminative, stomachic. A warm, grateful aromatic, chiefly employed in flatulence or as a flavour. 
The seeds should be crushed for use, and the infusion of 2 ounces to a pint of boiling water taken in wineglassful doses.

Preparations-Powdered Seeds: Dose, Io grains to 2 drachms. Fluid extract: Dose, 5 drops to $\frac{1}{2}$ drachm. Compound tincture B.P.: Dose, $\frac{1}{2}-\mathrm{I}$ drachm. Tincture U.S.P.: Dose, I drachm.

Distinctive character-Fruits ovoid or oblong, more or less triangular, longitudinally furrowed, varying in length from $\frac{2}{5}-\frac{4}{5}$ inch, or, in bleached samples, the angles are rounded and the surface smooth. The fruits should yield 75 per cent. of seeds. Seeds from ripe capsules are sold as split seeds, being broken in the process of extraction. The unbroken fruits are gathered before quite ripe, so as not to split open in drying.

CAROBA.

Jacaranda procera, Spreng. N.O. Bignoniacee.

Syn.-Carob Tree, Caaroba, Jacaranda Caroba, D.C., Bignonia Caroba, Vell.

Part used-Leaves.

Action-Alterative, diaphoretic, diuretic. In Brazil the natives use the Caroba in all venereal disorders, and it has been clinically experimented upon with success in syphilitic skin affections. It seems to have a sedative effect upon the nervous system, and it has been used in epilepsy.

The dose is from $15-60$ grains.

Distinctive character-Leaflets leathery, lanceolate, tapering below, obtuse at the apex, about $2 \frac{1}{2}$ inches long and I inch broad, minutely pitted on both surfaces, midrib prominent below, depressed above, veins spreading. Taste, bitterish; flavour, tea-like. Odour, none. 
CASCARA SAGRADA. Rhamnus Purshlana, D.C. N.O. Rhannacea.

Syn.-Sacred Bark.

Part used-Bark.

Action-Laxative, tonic. Largely used for habitual constipation, dyspepsia, and digestive complaints, also in the treatment of piles. For chronic constipation a first dose of half or I teasponnful at bedtime should be. taken, followed by doses of 5 -10 drops before each meal.

Preparations-Fluid extract B.P.: Dose, 5 drops to I drachm. Fluid extract U.S.P.: Dose, I5 drops. Fluid extract, tasteless: Dose, $\frac{1}{4}-\mathrm{I}$ drachm. Fluid extract, aromatic, U.S.P.: Dose, 15 drops. Solid extract B.P.: Dose, $2-8$ grains. Aromatic Syrup B.P.: Dose, $\frac{1}{2}-2$ drachms. Powder extract: Dose, 2-Io grains. Rhamnin: Dose, 2.6 grains.

Distinctive character-Bark in quilled or curved pieces about $\frac{3}{4}$ inch wide and $\frac{1}{16}$ inch thick, purplish brown, furrowed longitudinally with transversely linear marks (lenticels), sometimes silvery grey with lichens. The inner surface is transversely wrinkled and longitudinally striated, reddish brown. Transverse fracture pale or dark brown, according to age. Taste, persistently bitter or nauseous. Odour, leather-like. Specimens with dark brown fracture, indicating its having been kept, are to be preferred, as recent bark sometimes causes nausea.

CASCARA AMAROA. Picramnia Antidesma, S.W. N.O. Simarubacea.

Action-Bitter tonic. Said to have distinctly alterative properties.

Distinctive character-Bark in small fragments less than I inch long and about $\frac{1}{4}$ inch wide and $\frac{1}{8}$ inch thick, externally greyish, internally deep brown, inner surface 
nearly smooth. Transverse fracture short, showing numerous white dots due to groups of stone cells. Taste, at first astringent, then bitter; flavour, earthy.

CASCARILLA.

Syn.-Sweet Wood Bark.

\section{Part used-Bark.}

Action-Stimulant, aromatic, tonic. Used in dyspepsia, flatulence, and diarrhœa; in convalescence from acute diseases and to prevent vomiting. Often combined with Cinchona, when this causes nausea. The infusion of $I$ ounce to a pint of boiling water is taken in doses of a tablespoonful to a wireglassful as required.

Preparations-Powdered bark: Dose, 20.40 grains. Fluid extract: Dose, $\frac{1}{2}-\mathrm{I}$ drachm. Tincture B.P. : Dose, $\frac{1}{2}-I \mathrm{drachm}$. Infusion B.P.: Dose, $\frac{1}{2}-\mathrm{I}$ ounce.

Distinctive character-The bark occurs in short quilled pieces, up to $\frac{1}{2}$ inch in diameter, usually with a chalky, more or less cracked, white surface, with black dots due to the fruit of lichens. Transverse fracture reddish brown. Taste, aromatic, bitter. Fragrant when burnt.

Anacardium occidentale, Linn. N.O. Anacardiacea.

Syn.-Cassuvium pomiferum.

Part used-Nut.

Action-Nutritive. The roasted kernels are edible and of agreeable flavour. The fresh juice of the shell is acrid and corrosive, and the West Indian negroes use it for warts, corns, \&c. The tree-bark has proved efficient 
in certain malarial fevers not yielding to treatment by Quinine.

Distinctive character-Fruit kidney-shaped, smooth, greyish, about I inch long, $\frac{1}{2}$ inch broad and thick. The thick shell is porous and contains a dark acrid oil, dangerous to very sensitive skins. The nuts are roasted to obtain the kernels, which are edible when thus obtained.

CASSIA.

Cinnamomum Cassia, Blume.

N.O. Lauracea.

Syn.-Chinese Cinnamon, Cassia lignea, Cassia Bark.

Part used-Bark.

Action-Tonic, stomachic, carminative. Used for domestic purposes and as a substitute for Ceylon Cinnamon in medicine.

Distinctive character-The bark is in dull brown quilled pieces; sometimes remains of the epidermal layer are present. Quills not so thin and rarely inserted inside one another as in cinnamon. Taste and odour, aromatic, similar to Cinnamon but distinct.

CASTOR OIL PLANT. Ricinus communis, Linn. N.O. Euphorbiacca.

Syn.-Castor Oil Bush, Palma Christi.

Part used-Expressed oil of the seed.

Action-Cathartic, purgative. From its mildness of action this is especially adapted for young children and child-bearing women, and may be used in cases of constipation, colic, and in diarrhoea due to slow digestion. It is also used for removing worms, after other suitable remedies have been administered. Externally, it has been recommended for itch, ringworm, and cutaneous complaints. The nauseous taste can be covered by Lemon Oil, Sassafras Oil, and other essential oils, or it may be administered in fresh or warmed milk. The 
dose varies from I to 4 teaspoonfuls. The Canary Island women use the fresh leaves as an application to the breasts in order to increase the secretion of milk.

Distinctive character-The oil varies much in activity; as a rule the East Indian is most active and the Italian has the least taste.

CATECHU, PALE.

Uncaria Gambier, Roxb. N.O. Rubiacea.

Syn.-Terra Japonica, Gambir, Ourouparia Gambir, Baillon.

CATECHU, BLACK.

Syn,-Cutch.

Part used-Extract from leaves and young shoots of Uncaria Gambier and from the wood of Acacia Catechu.

Action-Astringent. Is used in chronic diarrhœea, chronic catarrh, and chronic dysentery. Useful for arresting excessive mucous discharges, and for checking hæmorrhages. Recommended as a local application in relaxed sore throat, sponginess of gums, \&c.

Preparations-Powdered Catechu: Dose, 5-1 5 grains. Compound powder B.P.: Dose, I0-40 grains. Tincture B.P.: Dose, $\frac{1}{2}-\mathrm{I}$ drachm. Comp. Tincture U.S.P.: Dose, I drachm. Lozenges B.P. and U.S.P.

Distinctive character-Two substances are sold under the name of Catechu. The one in black, shining pieces or cakes, sometimes with the remains of a leaf on the outside, derived from Acacia Catechu, which is known as Cutch or Black Catechu, and a second in dark or pale brown cubes with a dull powdery fracture, or sometimes in lozenge form, which is known as Terra Japonica, or Gambir, or Pale Catechu, and is derived from Uncaria Gambier. 
Syn.-Catmint.

Parts used-Herb, leaves.

Action-Carminative, tonic, diaphoretic, refrigerant. $\Lambda s$ it produces free perspiration it is very useful in colds, \&c. The infusion of I ounce to a pint of boiling water may be taken by adults in doses of 2 tablespoonfuls, by children in 2 or 3 teaspoonfuls frequently, to relieve pain and flatulence.

Distinctive character-Stem opaque, hairy, grey. Leaves stalked, cordate-ovate, pointed, incise-serrate, whitish, hairy beneath. Flowers white, two-lipped, upper lip straight, calyx tubular, lower stamens shortest, arranged in short, dense, branched spikes. Taste and odour, mint-like but characteristic.

CAYENNE.

Capsicum minimum, Roxb.

N.O. Solanacea.

Syn.-African Pepper, Guinea Pepper, Bird Pepper, Chillies, Capsicum fastigiatum, Bl.

Part used-Fruit.

Action-Stimulant, tonic, carminative, rubefacient. The purest and most certain stimulant in herbal materia medica. Produces natural warmth and equalises the circulation. Persons exposed any length of time to cold and damp may ward off disease by taking pills made of pure Cayenne, and a cold may generally be removed by one or two doses of the powder taken in warm water. Cayenne enters into many of the compounds of the herbal practice, and is one of the most important remedies.

Preparations-Powdered fruits: Dose, $\frac{1}{8}$-I drachm. Oleoresin U.S.P.: Dose, $\frac{1}{5}-\frac{1}{2}$ grain. Tincture B.P. and 
U.S.P.: Dose, 5-15 drops. Fluid extract U.S.P.: Dose, $\frac{1}{2}-3$ drops. Plaster U.S.P. Ointment B.P.

Distinctive character-The fruit varies much in colour, size, and pungency. The most pungent are those of Sierra Leone, but the colour is yellowish red. Japanese are bright red and longer, but less pungent. Zanzibar Chillies often have the stalks attached.

\section{CEDRON.}

Syn.-Cedron Seeds.

\section{Part used-Seeds.}

Action-Febrifuge, bitter, tonic, antispasmodic, sedative. The seeds are intensely bitter and have been employed in malarial complaints and in dyspepsia. The dose of the powdered seeds is I-IO grains, and the infusion of $\mathrm{I}$ ounce in a pint of boiling water may be given in doses of a tablespoonful three to four times a day.

Distinctive character-The Cedron seeds of commerce consist of the separated cotyledons; these are flattened on one side and convex on the other, and are of a greyish yellow tint about $\mathrm{I} \frac{1}{2}$ inch long and $\frac{1}{2}-\frac{3}{4}$ inch in diameter. Fracture short and yellowish. Taste, very bitter. Odour, recalling that of cocoanut.

CELANDINE. Chelidonium majus, Linn. N.O. Papaveracea.

Syn.-Garden Celandine.

Part used-Herb.

Action-Alterative, diuretic, purgative. Used in jaundice, scrofulous diseases, eczema, \&c. The infusion of I ounce of herb to a pint of boiling water is taken in 
wineglassful doses. The fresh juice makes an excellent application for corns and warts.

Preparation-Fluid extract: Dose, $\frac{1}{2}$-I drachm.

Distinctive character-Leaves pinnate, green above, greyish below, 6-1 2 inches long and 2-3 inches wide. Leaflets opposite, deeply cut with rounded teeth. Leafstalk flat above, convex beneath, with recurved hairs, exuding a saffron yellow juice when fresh and broken. Taste, acrid, bitter, and caustic. Odour, disagreeable.

CELERY.

Syn.-Smallage.

Part used-Seeds.

Action-Carminative, diuretic, tonic. Used as a flavour and a tonic in combination with other drugs such as Coca, Kola, Damiana, \&c. It is recommended as excellent in rheumatism. drops.

Preparation-Fluid extract U.S.P.: Dose, 5-30

Distinctive character-The seeds are very small, $\frac{1}{25}$ inch long, ovate, plano-convex, brown, with five paler longitudinal ribs. Taste and odour that of celery.

CENTAURY.

Erythræa Centaurium, Pers. N.O. Gentianacea.

Syn.-Century, Centory, Feverwort.

Parts used-Herbs, leaves.

Action-Aromatic, bitter, stomachic, tonic. Should be given in conjunction with Barberry Bark in cases of jaundice. Is used extensively in dyspepsia. The dose 
of the infusion of I ounce to I pint of boiling water is a wineglassful.

\section{Preparation.-Fluid extract: Dose, $\frac{1}{2}-\mathrm{I}$ drachm.}

Distinctive character-Stem 8-I2 inches high, with opposite, lanceolate-ovate leaves, having three to five longitudinal ribs, hairless, and entire at the margins. Flowers pink, with twisted anthers. Taste, bitter. Odour, slight, disappearing when dried.

\section{CHAMOMILE.}

Anthemis nobilis, Linn.

Syn.-Roman Chamomile.

N.O. Composita.

Parts used-Flowers, herb.

Action-Stomachic, antispasmodic, tonic. An oldfashioned but extremely efficacious remedy for hysterical and nervous affections in women. Also used as an emmenagogue. The flowers combined with crushed poppy-heads make a good poultice for allaying pains, when other means have failed. As a lotion it is also excellent for external application in toothache, earache, neuralgia, \&c. The herb and flowers are equally valuable. The dose of the infusion of I ounce to a pint of boiling water is a tablespoonful to a wineglassful. The herb is also used in the manufacture of herb beers. As a tonic the Powdered Flowers may be used in doses of $\frac{1}{2}-\mathrm{I}$ drachm three times a day.

Preparations-Fluid extract, flowers: Dose, $\frac{1}{2}-1$ drachm. Solid extract B.P.: Dose, $2-8$ grains. Oil B.P.: Dose, $\frac{1}{2}-3$ drops.

Distinctive character-Flowers double, i.e., consisting entirely of ligulate florets, a bout $\frac{1}{2}$ inch in diameter, leaving, when pulled off, a conical, solid receptacle, covered with lanceolate membranous scales (paleæ). Leaves pinnately divided into short and hairy leaflets. Taste, aromatic and very bitter. In English Camomile Flowers a few of the central florets are tubular. Wild Camomile Flowers, having only an outer row of ligulate florets, are known as Scotch Camomiles. 


\section{CHAMOMILE, GERMAN.}

Matricaria Chamomilla, Linn. N.O. Compositce.

Part used-Flowers.

Action-Carminative, sedative, tonic. It is an excellent remedy in children's ailments. It acts as a nerve sedative and also as a tonic upon the gastrointestinal canal. Useful during dentition, in cases of earache, neuralgic pains, stomach disorders, and infantile convulsions. The infusion of $\frac{1}{2}$ ounce to a pint of boiling water may be given freely in teaspoonful doses to children. Also used externally as a fomentation.

Preparation-Fluid extract: Dose, 1-I drachm.

Distinctive character-The flowerheads are much smaller than the preceding; and have only one row of ligulate florets; which are usually bent backwards when dry. The receptacle is conical and hollow, and has no membranous bracts on it. Taste, bitter and aromatic. Odour, like the preceding, but weaker. The florets readily fall off.

CHAULMOOGRA.

Taraktogenos Kurzii, King. N.O. Bixacea.

Syn. - Chaulmugra, Chaulmogra.

These seeds were for some years supposed to be the produce of Chaulmoogra odorata, Roxb., but it has recently been shown that the seeds of that plant are quite different:

Parts used-Seeds, oil.

Action-Sedative, febrifuge, dermatic. The seeds may be given internally, when powdered and made into pills, in doses of 3-6 grains. The oil expressed from the seeds has been much praised as an internal and external remedy in scrofulous, syphilitic, and rheumatic skin affections. It has proved itself a valuable agent in stiffness of joints and cutaneous eruptions such as 
eczema and psoriasis. The best form is the ointment made of I part of oil to 4 of base. For internal administration the oil is administered in the form of an emulsion with almonds or milk.

Distinctive character-Seeds greyish, about I inch long and $\frac{5}{8}$ inch in diameter, irregularly angular with rounded ends. Kernel (albumen) oily, enclosing two thin heart-shaped three-veined cotyledons with a straight radicle. Taste, somewhat acrid, and odour, disagreeable.

CHEKEN.

Eugenia Chequen, Molina. N.O. Myrtacea.

Syn.-Chekan, Chequen, Myrtus Cheken, Spreng.

Part used-Leaves.

Action-Diuretic, expectorant, tonic. Is reputed to be a valuable remedy in catarrhal disorders of respiratory organs. Dr. Murrell, of London, claims it to be excellent in winter coughs of elderly persons.

Preparation-Fluid extract: Dose, I-2 drachms.

Distinctive character-Leaves leathery, ovate, $\frac{5}{8}$-I inch long, $\frac{1}{4}-\frac{1}{2}$ inch wide, and entire at the margins, very shortly stalked with numerous minute, round, translucent oil cells. Twigs with opposite leaf scars. Taste, astringent and bitter; flavour, aromatic, recalling that of bay leaves. Odour, very slight.

CHERRYLAUREL.

Part used-Leaves.
Prunus Laurocerasus, Linn. N.O. Rosacea.

Action-Sedative. Mostly used to produce cherrylaurel water, and as such, of value in cough, whooping cough, and asthma, as an addition to other medication. Also useful in dyspepsia, indigestion, \&c.

Preparation-Water B.P.: Dose, $\frac{1}{2}-2$ drachms.

Distinctive character-Leaves leathery, shining, ahout $5^{-6}$ inches long by $1 \frac{1}{2}-2$ inches wide, oblong, 
lanceolate, pointed, and serrate at the margins. At the back of the leaf there are two or three dot-like glands close to the midrib near the base. Odour, when the fresh leaves are bruised, like that of oil of bitter almonds.

\section{CHERRY STALKS.}

Prunus avium, Linn. (and other species). N.O. Rosacea.

Action.-Tonic, and slightly astringent.

Distinctive character-Fruitstalks about $\mathrm{I}$ inch long and $\frac{x}{2 t}$ inch in thickness, enlarged at one end. The stalks of various species are collected indifferently, viz., $P$. Cerasus, Linn., and $P$. duracina, Sweet, i.e., of the red, black, and white or Bigarreau cherries. Taste, bitter and astringent.

CHESTNUT.

Castanea vesca, Gaertn. N.O. Cupulifere.

Syn.-Castanea dentata, Borkh., Castanea vulgaris, Lam.

Part used-Leaves.

Action-Tonic, astringent. In some places chestnut leaves are used as a popular remedy in fever, ague, \&c. Their reputation, however, rests upon their remarkable efficiency in paroxysmal or convulsive coughs, whooping coughs, and other irritable and excitable conditions of the respiratory organs. The infusion of $I$ ounce of leaves in a pint of boiling water is administered in tablespoonful to wineglassful doses, repeated three to four times daily.

Distinctive character-Leaves leathery, about 6-8 inches long, and 21 inches broad, oblong lanceolate, feather-veined, margins with distant sharp-pointed, spreading teeth. In the American form of the tree (Castanea dentata) the teeth are curved forward. Taste, astringent. Odour, none. 
CHICKWEED. Stellaria media, Cyrill. N.O. Caryophyllacee. Syn. - Alsine media, Linn., Starweed, Star chickweed. Part used-Herb.

Action-Demulcent, refrigerant. The fresh leaves have been used as a poultice to indolent ulcers, with most beneficial results. $\mathrm{H}$ as also been employed as an application in ophthalmia and as an ointment in cutaneous diseases.

Distinctive character-Stems jointed, with a line of hairs down one side only. Leaves ovate, about $\frac{1}{2}$ inch long by $t$ inch broad with flat stalks below, stalkless above. Flowers singly in the axils of the upper leaves, petals white and narrow, shorter than the calyx. Taste, slightly saline." Odour, none.

CHICORY.

Cichorium Intybus, Linn. Syn. - Succory, Wild Succory. N.O. Composite.

Part used-Root.

Action-Tonic, diuretic, laxative. A decoction of I ounce of the root to a pint of boiling water and taken freely: has been found effective in jaundice, liver enlargements, gout, and rheumatic complaints.

Distinctive character - Root brownish, with tough, loose, reticulated white layers surrounding a radiate woody column. Often crowned with remains of the stem. Táste, bitter, mucilaginous. Odour, none. (n)

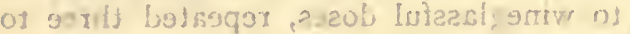

\section{CHINA.}

Smilax China, Linn.

Part used-Root.

Action-Alterative, antisyphilitic. Used occasionally as a substitute for Sarsaparilla and for similar purposes.

- Distinctive character-Tubers cylindrical, somewhat flattened sometimes, 4-6 inches lóng and or 2 
inches in thickness, with short, knotty branches, and a: rusty, shining bark. Internally, of a pale fawn colour. Taste, insipid. Odour, none.

CHIRETTA.

Swertla Chirata, Buch-Ham.

N.O. Gentianacea.

Syn.-Chirata, Chirayta, Ophelia Chivata, Griseb.

Part used-Herb.

Action-Bitter tonic. May be used wherever a tonic is required. The dose of the infusion of $\frac{1}{2}$ ounce to I pint of water is half to one wineglassful.

Preparations-Fluid extract: Dose, $\frac{1}{2}-1$ drachm. Tincture B.P.: Dose, $\frac{1}{2}-I$ drachm. Infusion B.P.: Dose, 4-8 drachms. Conc. Solut. B.P.: Dose, $\frac{1}{2}-1$ drachm. Solid extract : Dose, 4-8 grains.

Distinctive character-Stems brown or purplish, $\frac{2}{10}-\frac{3}{10}$ inch thick, "cylindrical below, quadrangular upwards, containing a large pith. Leaves opposite, entire with three to seven longitudinal ribs. Capsules, one-celled, two-valved. Taste, intensely bitter. Odour, none.

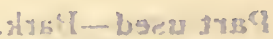

CICELY, SWEET.

Myrrhis odorata, Scop. N.O. Umbellifera.

Syn.-Smoother Cicely, Sweet Chervil.

Parts used-Root, herb.

Action-Carminative, stomachic, expectorant. The fresh root may be eaten freely. It is found useful in coughs and fiatulence, also as a gentle stimulant in indigestion and stomachic complaints. The dried root is best used in the form of a decoction, and the herb in an infusion.

Distinctive character-Leaves large, tripinnate, leaflets hairy on the veins below and on the margins, 
leafstalks with spreading hairs. Leaflets ovate lanceolate, usually with white splashes near the base of the larger ones. Taste, sweet anise-like. Root whitish, $\frac{1}{2}-I_{2}^{\frac{1}{2}}$ inch broad, with small central columns and radiate structure, the medullary rays curved in the bark. Osmorhiza longistylis, D.C. (Uraspermum Claytoni, Nutt.), yields American Sweet Cicely.

\section{CINERARIA MARITIMA, Linn.}

Seneclo marltimus, Linn. N.O. Composite.

Action-One or two drops of the fresh juice dropped into the eye is said to be of use in removing cataract.

Distinctive character-Leaves $5-8$ inches long and about 2-2t inches wide, pinnately divided, segments about three lobed, white, with a dense white coating of hairs beneath. Flowerheads yellow, about $\frac{8}{8}$ inch in length.

CINNAMON.

Clnnamomum Zeylanicum, Nees.

N.O. Lauracea.

Part used-Bark.

Action-Aromatic, astringent, stimulant, carminative. A fragrant cordial especially useful for weakness of the stomach and diarrhœa. Checks nausea and vomiting. Generally combined with other remedies.

Preparations-Tincture B.P.: Dose, $\frac{1}{2}-\mathrm{I}$ drachm. Oil B.P.: Dose, $\frac{1}{2}-3$ drops. Water. Comp. Powder, aromatic, B.P.: Dose, 10.40 grains. Spirit B.P.: Dose, 5-20 drops.

Distinctive character-In pale brown, thin quills, several rolled in one another. Quills usually $\frac{8}{8}-\frac{5}{8}$ inch in width, but not exceeding $\frac{1}{16}$ inch in thickness. Taste, sweet, pungent, and aromatic. Odour, characteristic. 
CLARY, SWEET.

Syn.-Clarry, Clear-eye.

Parts used-Leaves, herb.

Action-Antispasmodic, balsamic. This plant has been used both fresh and dry. Mostly employed in disordered states of digestion as a stomachic. It has also been of service in kidney diseases with good results. The mucilage of the seeds has been used in ophthalmic disorders.

Distinctive character-Leaves large, heart-shaped, pointed, wrinkled, covered with velvety hairs. - Flowers blue or white, with large membranous bracts longer than the calyx. Taste, warm and aromatic, slightly bitter. Odour, aromatic, recalling that of Tolu.

CLIVERS.

Galium Aparine, Linn. N.O. Rubiacea.

Syn.-Cleavers, Goosegrass, Hayriffe, Erriffe, Burweed, Goosebill.

Part used-Herb.

Action-Aperient, diuretic, tonic, alterative. Should be given in obstruction of urinary organs, suppression of urine, gravelly deposits, \&c. Acts as a solvent of stone in the bladder. The infusion, hot or cold, of I ounce to I pint of water is taken frequently in wineglassful doses.

Preparation-Fluid extract: Dose, $\frac{1}{2}-\mathrm{I}$ drachm.

Distinctive character-Stem quadrangular. Leaves lanceolate, about $\frac{1}{2}$ inch long and $\frac{1}{4}$ inch broad, in rings of six, with backward bristly hairs at the margins. Fruit nearly globular, about $\frac{1}{8}$ inch in diameter, covered with hooked bristles. Taste, slightly saline. Odour, none. 
CLOVES.

Eugenia caryophyllata, "Thunb. N.O. Myrtacece.

Syn. - Caryophyllus aromaticus, Linn., Eugenia aromatica, Willd.

Part used-Buds.

Action-Stimulant, aromatic, carminative. A warm, stimulating aromatic, used chiefly in combination with other remedies.

Preparations-Fluid extract: Dose, 5-30 drops. Oil: Dose, I-5 drops. Infusion B.P.: Dose, $\frac{1}{2}-1$ ounce.

Distinctive character-Flower buds brown, nailshaped, the lower portion consisting of calyx tube enclosing in its upper half the ovary filled with minute ovules. Calyx teeth four, surrounded by the unopened globular corolla of four concave over-lapping petals. Stamens numerous. Taste, hot. Flavour, that of cloves. On pressing the calyx tube with the finger nail, oil should exude.

CLOWNSWORT. Stachys sylvatica, Linn. N.O. Labiatce.

Distinctive character-Leaves opposite, on square stems, heart-shaped, hairy, long-stalked, margins bluntly serrate. Bracts underneath the terminal flowers linear, not toothed. Flowers reddish purple. Seeds (pyrenes) rough with minute depressions and warts. Taste, insipid. Odour, strong when fresh.

CLUBMOSS.

Lycopodium clavatum, Linn. N.O. Lycopodiacece.

Syn.-Lycopodium, Lycopodium Seed, Vegetable Sulphur.

Parts used-Plant and Spores (seeds).

Action-Sedative, emollient. Lycopodium has long been utilised for dusting over pills and the making of 
fireworks. Lately it has come into prominence as a remedy for internal use in urinary disorders, and has rendered a good service in the treatment of spasmodic retention of urine in children, catarrhal cystitis, and in chronic kidney diseases causing pain in kidneys, ureters and bladder, and associated with rheumatic symptoms. It is efficient as a gastric sedative in indigestion, dyspepsia, and catarrhal gastritis. Dose, 10-60 grains.

Distinctive character-Stem woody, slender, elongated, with a few lateral forked branches, and a few scattered whitish roots below. Leaves crowded and scale-like, hair-tipped. Spore cases in spikes borne on erect, forked, club-shaped branches, at right angles to the prostrate stem, spores somewhat triangular, yellow, forming a mobile powder which floats on water without being wetted.

COCA BOLIVIAN.

Erythroxylon Coca, Lank. N.O. Linacea.

Syn.-Erythroxylon Truxillense, Rusby.

Part used-Leaves.

Action-A powerful nerve stimulant and anodyne. Coca prevents fatigue, and the leaves are chewed by the South American natives to enable them to perform feats of endurance. Is also used in the treatment of asthma and as an aphrodisiac and a general nerve tonic. The leaves contain an alkaloid, "Cocaine," which is used as an anæsthetic.

Preparations-Fluid extract B.P. and U.S.P. : Dose, 1-I drachm. Solid extract: Dose, 5-10 grains. Wine U.S.P.: Dose, 4 drachms.

Distinctive character-Leaves are brownish green, oval, thin but tough, nearly 2 inches long and I inch wide, with two lines on the under surface parallel to the midrib, margins entire, apex rounded, a faint projecting line occurs on the upper surface of the midrib. Peruvian leaves, derived from Erythroxylon Truxil- 
lense, Rusby, are green, oblanceolate and very brittle, but tapering below; about $\mathrm{I}_{\frac{1}{2}}$ inch long and $\frac{1}{2}$ inch broad in the upper half, without any projecting line on the midrib.

\section{COCCULUS INDICUS.}

Anamirta paniculata, Colebr. N.O Menispermacece.

Syn.-Fish Berries, Indian Berries.

Part used-Berries or seeds.

Action-Stimulant, parasiticide. Though very poisonous, it has occasionally been given internally for similar purposes as Nux Vomica and its preparations. As an ingredient of an ointment it has been used in obstinate skin diseases, such as barber's itch, \&c.

Preparations-Fluid extract: Dose, $\frac{1}{4}-\mathrm{I}$ drop. Picrotoxin B.P.

Distinctive character-Fruits roundly kidneyshaped, $\frac{4}{10}-\frac{5}{10}$ inch long, blackish, containing a horseshoe-shaped seed. Fruitshell tasteless, seed bitter and oily.

COFFEE.

Syn.-Caffea.

Part used-Seeds, and active principle "Caffeine."

Action-Stimulant, anti-narcotic, anti-emetic. As a beverage Coffee is well known, and is often used in domestic practice as a remedy in headache and as a general stimulant. When taken in excess it produces unpleasant heart symptoms. As a medicinal agent the beverage made from roasted seeds may be used, or the Caffeine, where a heart stimulant is needed. In narcotic poisoning it forms a valuable adjunct, as it dispels stupor 
and drowsiness, and is also used in cases of alcohol habit. Possessing decided diuretic properties it can be employed with advantage in gout, rheumatism, and gravel. Dropsies of cardiac origin are also benefited by it. The dose of Caffeine is from $\frac{1}{2}$-Io grains.

Distinctive character-Caffeine occurs in commerce in silky white crystals. The seeds are oval, concave on one side, flat on the other, greenish grey, with a central longitudinal furrow.

COHOSH, BLACK.

Clmicifuga racemosa, Nutt.

N.O. Ranunculacea.

Syn. - Black Snakeroot, Rattleroot, Rattleweed, Squa wroot, Actcea racemosa, Linn., Macrotys actcoides, Raf.

Part used-Root.

Action-Astringent, diuretic, emmenagogue, alterative. In small doses useful in children's diarrhœa. In paroxysms of consumption it gives relief by allaying the cough, reducing rapidity of pulse, and inducing perspiration. Is specially recommended in cases of obstructed menses. In whooping cough its action is very highly spoken of. Said to be a specific in St. Vitus's Dance of children. Overdoses produce nausea and vomiting.

Preparations-Fluid extract U.S.P.: Dose, I5-30 drops. Liquid extract B.P.: Dose, 5-30 drops. Tincture B.P.: Dose, I 5 drops to I drachm. Cimicifugin or Macrotin: Dose, I.6 grains. Powdered extract U.S.P.: Dose, 4 grains. Tincture U.S.P.: Dose, I drachri. Solid extract: Dose, I-3 grains.

Distinctive cliaracter-Rhizome blackish, with short lateral branches, cylindrical, compressed, marked with transverse leaf scars. Transverse section horny, enclosing a ring of woody tissue within a hard, thick bark. Rootlets, when present, show on transverse section the woody tissue like a Maltese cross. Taste, bitter and acrid, and rather astringent. Odour, disagreeable. 
COHOSH, BLUE. Caulophyllum thalictroides, Mich. N.O. Berberidacece.

Syn.-Pappoose Root, Leontice thalictroides, Linn.

Part used-Root.

Action-Demulcent, antispasmodic, emmenagogue. Very efficacious in rheumatic affections and female complaints. The Indian women use it largely to expedite parturition and to induce menstruation.

Preparations-Fluid extract: Dose, I0-30 drops. Solid extract : Dose, 5-Io grains. Caulophyllin: Dose, 2-5 grains.

Distinctive character-Rhizome brownish grey, about 4 inches long and $\frac{1}{4}-\frac{2}{5}$ inch thick, and knotty with short branches, with numerous, crowded, concave stemscars, on the upper side; furnished below with long, pale brown, tough rootlets about $\frac{1}{25}$ inch thick ; internally whitish, with narrow woody rays. . Taste, sweetish, then bitter and acrid. Nearly inodorous.

Syn.--Meadow Saffron, Naked Ladies.

N.O. Liliacea.

Parts used-Root, seeds.

Action-Antirheumatic, cathartic, emetic. Its reputation rests largely upon its value in acute gouty and rheumatic complaints. Mostly used in connection with some alkaline diuretic. Also given in pill form. Overdoses cause violent purging, \&c.

Preparations-Powdered root: Dose, 2-5 grains. Extract B.P.: Dose, $\frac{1}{4}-I$ grain. Liquid extract, root : Dose, I-Io drops. Fluid extract, seeds, U.S.P?: Dose, I-Io drops. Tincture B.P.: Dose, 5-I 5 drops. Wine B.P.: Dose, I0-30 drops. Solid extract, root, U.S.P.: Dose, I grain. Acetic solid extract: Dose, $\frac{1}{4}-I$ grain.

Distinctive character-The corm or root is usually sold in transverse slices, notched on one side, and some- 
what reniform in outline, white and starchy internally, about $\frac{1}{8}$ inch thick, and varying from $\frac{3}{4}-\mathrm{I}$ inch in dia. meter. Taste, sweetish, then bitter and acrid. Odour, radish-like in the fresh root, but lost in drying.

The seeds are dull brown, nearly spherical, finely pitted, with a crest-like appendage at the hilum, very hard and horny, with a minute embryo. Taste, bitter and acrid. Odour, none.

COLTSFOOT.

Syn.-Coughwort, Horsehoof.

\section{Part used-Leaves.}

Action-Demulcent, expectorant. This is one of the most popular of cough remedies, and is generally given in conjunction with one or two other herbs possessing pectoral qualities, such as Horehound, Marshmallow, Ground Ivy, \&c. A decoction is made of $I$ ounce of leaves in I quart of water boiled down to I pint, and is taken in teacupful doses sweetened.

\section{Preparation-Fluid extract: Dose, $\frac{1}{2}-1$ drachm.}

Distinctive character-Leaves hoof-shaped with angular teeth on the margins, about 4 inches in diameter, long-stalked, green above, coated with matted long white hairs beneath and on the upper surface when young. Taste, mucilaginous, bitterish, and slightly astringent.

\section{COLUMBO, AMERICAN.}

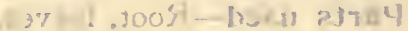

Frasera Carolinensis, Walt. N.O. Gentianacea.

¿. Syn.-Frasera Walteri, Frasera Canadensis.

Part used-Root.

Action-Tonic, stimulant. This drug is a gentle stimulant and may be serviceable in all cases 'where a 
bitter tonic is required, as it gives tone to the whole system and is reputed to relieve obstinate constipation. The infusion may be taken in doses of a wineglassful three to four times a day. The dose of the powder is from 20-60 grains.

\section{Preparation-Fraserin: Dose, I-3 grains.}

Distinctive character-Root in pieces, 3-4 inches long and about $\frac{1}{2}-1$ inch thick, often split longitudinally, the thick bark overlapping on the edges, pale brownish grey and transversely wrinkled externally above and longitudinally below. Transverse section pale yellowish brown or fawn colour. Fracture short and rather spongy. Taste, sweetish then bitter ; flavour resembling Gentian.

COMBRETUM.

Combretum Sundaicum, Miq.

Syn.-Opium Antidote.

N.O. Combretacea.

Distinctive character-Leaves $4-5$ inches long and about $2 \frac{1}{2}$ inches broad, with 8-ro lateral spreading nerves, perforated in the axils, surface minutely scaly on the young leaves. Taste, slightly astringent and tea-like. Odour, none.

\section{COMFREY.}

Syn.-Nipbone, Knitbone.

Symphytum officinale. Linn. N.O. Boraginacece.

Parts used-Root, leaves.

Action-Demulcent, astringent. Is very highly esteemed as a remedy in all pulmonary complaints, hemoptysis, and consumption, and forms an ingredient in a large number of herbal preparations. Wherever a mucilaginous medicine is required this may be given. Has been used of late by the medical profession as a poultice to promote healing of obstinate ulcerous wounds. A decoction is made by boiling $\frac{1}{2}-I$ ounce of 
crushed root in I quart of water or milk. Dose, a wineglassful. The leaves are preferably taken as an infusion prepared in the usual manner.

Preparation-Fluid extract: Dose, $\frac{1}{2}-2$ drachms.

Distinctive character-Root brownish black, deeply wrinkled, in pieces 3-6 incles long and $\frac{1}{2}-\frac{3}{4}$ inch thick, greyish and horny internally. Fracture short. Transverse section showing a thick bark, short wood bundles and broad medullary rays. Taste,sweetish, mucilaginous, and faintly astringent. Odour, none.

CONDURANGO. Marsdenia Cundurango, Nichols. N.O. Asclepiadacece. Syn.-Gonolobus Condurango (Triana).

Part used-Bark.

Action-Alterative, stomachic, aromatic.

Preparation-Fluid extract: Dose, $\frac{1}{2}$-I drachm.

Distinctive character-In quilled pieces $2-4$ inches long, about $\frac{1}{2}$ inch in diameter, and $\frac{1}{12}-\frac{1}{4}$ inch thick. Outer surface brownish grey, with scattered warts of the same colour. Transverse fracture yellowish white, granular, with scattered fine silky fibres. Taste, bitter and somewhat acrid, and faintly aromatic.

CONTRAYERVA.

Syn.-Dorstenia, Houstoni, Linn.

Dorstenia Contrajerva, Linn. N.O. Urticacece.

Contrayerva is also obtained from $D$. Braziliensis, Lam., D. Drakena, Linn., D. opifera, Fisch., and D. tubicina, R. and $\mathrm{P}$.

Part used-Root.

Action-Diaphoretic, stimulant. These properties make it a good remedy in typhus fever, dysentery, and skin diseases. The powder is taken in doses of 30 
grains, but the infusion of I ounce in a pint of boiling water is the best form of administration.

Distinctive character-Rhizome about $I-I \frac{1}{2}$ inch long and $\frac{3}{8}$ inch thick, reddish brown, rough, with leaf scars, nearly cylindrical, tapering suddenly at the end into a tail-like root furnished with numerous curled, wiry, reddish brown roots, and $2-3$ inches long. Transverse section horny, showing a thick bark, narrow interrupted ring of wood and a large horny pith. Taste, slightly aromatic, becoming acrid on mastication, causing a flow of saliva. Odour, not unpleasant.

COOLWORT.

Syn.-Mitrewort.

\section{Part used-Herb.}

Action-Diuretic, tonic. In cases of gravel, suppression of urine, and most complaints affecting the urinary organs, it is very useful. In dyspepsia and liver disorders it acts as a tonic and counteracts acidity of the stomach. The infusion of I ounce to I pint of boiling water is taken frequently in doses of a wineglassful.?

Distinctive character-Leaves with long slender stalks; heart-shaped, $2 \frac{1}{2}$ to $4 \frac{1}{2}$ inches wide, radiate-veined with $5^{\text {-I } 2}$ sharp lobes; which are irregularly toothed, the teeth having a sharp point. Taste, faintly astringent. Inodorous.

COPAIBA.

Copaifera Langsdorffil, Desf. N.O. Leguminosa.

Syn.-Copaiva, Capivi, Balsam Copaiva, Balsam Capivi.

Part used-Oleoresin.

Action-Stimulant, diuretic, cathartic. 'Used in excessive mucous discharges, as in chronic gonorrhoea, gleet, leucorrhoea, chronic catarrh of bladder, \&c. On 
account of taste is generally given in pill or capsule form, mostly in combination with alkalines or Santal Oil, Cubebs, \&c. Dose (B.P.), $\frac{1}{2}$-I drachm.

\section{Preparation-Oil B.P.: Dose, 5-20 drops.}

Distinctive character-The oleoresin differs much in appearance and fluidity. The Para kind is yellowish and comparatively fluid. The Maracaibo and Maranham varieties are thicker and fluorescent, and of a redder tint. The former contains more volatile oil, from 60 to 90 per cent., the latter more resin and only 40 per cent. of oil. The thinner kinds are usually preferred in this country, the thicker in Germany. It is derived from several species of Copaifera, besides $C$. Langsdorffi.

CORIANDER.

Part used-Fruit.

Action-Stimulant, carminative. Mostly used as a flavouring.

Preparations-Powdered fruit: Dose, 10-60 grains. Fluid extract: Dose, 5-30 drops. Oil B.P.: Dose, $\frac{1}{8}-3$ drops.

Distinctive character-The fruits are globular, about $\frac{1}{5}$ inch in diameter, with fine longitudinal ridges, separable into two halves (mericarps), each of which is concave internally and shows two brown longitudinal oil cells (vittæ). Taste, aromatic. Odour, when crushed, characteristic.

CORN ERGOT.

Ustilago Maydis, Leveille. N.O. Fungi.

Syn.-Cornsmut, Cornbrand, Ustilago.

Part used-Fungus.

Action-Emmenagogue, parturient. A favourite remedy of Dr. Ellingwood in labour, post-partum hæmorrhages, and hæmorrhages of lungs, bowels, 
\&c. Useful in spermatorrhœa, amenorrhœa, dysmenorrhœa, and other menstrual derangements. Dose, I-20 grains.

Preparation-Fluid extract: Dose, $\frac{1}{4}-\frac{1}{2}$ drachm.

Distinctive character-A blackish powder in irregular globose masses, somewhat lobed, and sometimes 6 inches or more in thickness. Powder consisting of inumerable fungus spores, with portions of the blackish, enclosing membrane. The spores are rounded, with a rough surface, as seen under the microscope. Taste, unpleasant. Odour, heavy. It should be kept dry, and obtained fresh every year. The name Corn smut is more applicable as the name Ergot is applied to a solid form of fungus mycelium. (See Ergot).

CORNFLOWER.

Centaurea Cyanus, Linn. N.O. Composita.

Syn.-Bluebottle, Bluebow, Hurtsickle, Bluet, Fr.

Part used-Flowers.

Action-Tonic, emmenagogue, stimulant. Its action is very much alike to that of Holy Thistle, which see.

Distinctive character-The flower-heads are globular, with closely overlapping fringed scales, and bright blue tubular florets, of which the outer are trumpetshaped, seven-lobed, and about $\frac{3}{4}$ inch long. Taste, scarcely any. Odour, none.

CORN SILK.

Syn.-Stigmata maidis.

Part used-Flower pistils.

Action-Demulcent, diuretic. Recommended as a valuable remedy in many urinary troubles, bladder affections, \&c. Especially useful in purulent decomposition of urine in the bladder. The infusion of 2 ounces 
in a pint of boiling water is a most active preparation, and should be freely taken.

Preparation-Fluid extract: Dose, $\frac{1}{2}-2$ drachms.

Distinctive character-Fine silky yellowish threads about 6 inches long and $\frac{1}{50}$ inch in diameter, finely hairy, consisting of the stigmas from the female flowers of maize. Taste, sweetish. Odour, none.

CORSICAN MOSS.

Alsidium Helminthocorton, Kütz.

Syn.-Fucus Helminthocorton, Linn.

N.O. Alga.

Part used-Plant.

Action-Anthelmintic, vermifuge. Acts very powerfully on lumbricoid intestinal worms. The dose is from 10.60 grains taken with honey, treacle, syrup, or made up as an infusion.

Distinctive character-In tangled tufts of slender brownish white, cylindrical threads showing under the microscope transverse series of small oblong cells which give it a striated appearance. Taste, saline. Odour, that of seaweed.

coto.

Part used-Bark.
Botanical source unknown. N.O. Lauracea.

Action-Antiseptic, astringent. Used with good results in intestinal catarrh, diarrhcea, and dysentery. A decoction of I ounce of bark in a pint of boiling water may be taken in tablespoonful doses or more as required.

Preparations-Powdered bark: Dose, 2-I5 grains. Fluid extract: Dose, 5-I5 drops. Cotoin: Dose, I-3 grains.

Distinctive character-Genuine Coto Bark is no longer to be met with in commerce. Paracoto bark, which is now very rare in commerce, occurs in curved thick pieces 4-6 inches or more long, and about $2 \frac{1}{2}$ inches 
wide, and $\frac{1}{2}-\frac{3}{4}$ inch thick, of a full brown colour, a more or less corky outer surface, sometimes with patches of whitish epidermis, and a rough, coarsely striated inner surface. The transverse section shows numerous small groups of stone cells. Taste, hot and biting. Flavour, aromatic. The edges of the section, both transverse and longitudinal, if kept in a bottle, become coated with a fine whitish crystalline efflorescence.

COTTON ROOT. Gossypium herbaceum, Linn.

Part used-Bark of root.

N.O. Malvacea.

Action-Emmenagogue, parturient, oxytocic. Said to contract the uterus in a more effective and safe manner than Ergot. Used in cases of difficult and obstructed menstruation. It seems specially useful in sexual lassitude. An infusion of 2 ounces to a pint of boiling water is taken in wineglassful doses.

The seeds produce by pressure an oil, Ol. Gossypii, official in U.S.P. as Cotton Seed Oil.

Preparations-Fluid extract: Dose, I-2 drachms. Gossypiin: Dose, I-5 grains. Solid Extract: Dose, ז5-20 grains.

Distinctive character-In flexible or quilled strips, brownish yellow externally with faint longitudinal ridges or meshes, circular black dots or short transverse lines and brownish orange spots where the epidermal surface is abraded. Inner surface whitish, with a silky lustre. Inner bark of long tough fibres, separable in papery layers. Taste, faintly acrid and astringent.

COUCHGRASS.

Agropyrum repens, Beauv. N.O. Graminacea.

Syn.-Twitchgrass, Quickgrass, Doggrass, Triticum repens, Linn.

Part used-Rhizome (root).

Action-Diuretic, demulcent, aperient. Used in urinary and bladder complaints, cystitis, nephritis, \&c. 
Also recommended in gout and rheumatism. The infusion, made from I ounce in a pint of boiling water, is taken in wineglassful doses several times daily for feverishness, \&c.

Preparation-Fluid extract: Dose, $\frac{1}{2}-2$ drachms.

Distinctive character-Rhizome slender, tubular, about $\frac{1}{10}$ inch in diameter, stiff, shining pale yellow, smooth, with nodes at intervals of about an inch. It is met with in commerce, cut up into short lengths of $\frac{1}{8}$ and $\frac{1}{4}$ inch, and dried. Taste, slightly sweet. Odour, none.

COWHAGE.

Dolichos pruriens, Linn. N.O. Leguminosa.

Syn.-Cowage, Cowitch, Mucuna pruriens, D.C.

Part used-Hairs of pods.

Action-Anthelmintic, rubefacient. In doses of half to I teaspoonful in honey, syrup, \&c., it expels intestinal worms. In the form of an ointment it acts similarly to Croton Oil, producing no inconvenience.

Distinctive character-The hairs of the pod are brownish, about $\frac{1}{10}$ inch long, and consist of a conical, sharply-pointed cell, about $\frac{1}{40}$ inch in diameter, barbed at the apex. Considerable caution should be used in handling this drug as the hairs are extremely irritating to the skin.

COWSLIP.

Primula veris, Linn. N.O. Primulacea.

Syn.-Paigles.

Part used-Flowers.

Action-Sedative, antispasmodic. Useful in restlessness, insomnia, \&c. See also Primrose.

Distinctive character-The corolla, which is the part used, is tubular and yellow and about $\frac{1}{2}$ inch across, 
but becomes green on drying; it is dilated near the throat, where it is folded and spotted with yellowish orange. The corolla is five-lobed and about $\frac{1}{2}$ inch in width. Taste, sweetish. Odour, recalling that of a pricots.

CRAMP BARK.

Viburnum Opulus, Linn. N.O. Caprifoliaced.

Syn.-High Cranberry, Guelder Rose, Snowball Tree.

Part used-Bark.

Action-Antispasmodic, nervine. As its name implies, it is very effectual in cases of cramp, convulsions, and spasms of all kinds, and is held in high esteem by all who employ it. It is chiefly used in combination as a tincture (see Antispasmodic Tincture), but may be given as a decoction by using $\frac{1}{2}$ ounce in I pint of water. Dose, a tablespoonful to a wineglassful as required.

Preparations-Fluid extract: Dose, $\frac{1}{2}-2$ drachms. Viburnin: Dose, I-3 grains.

Distinctive character-Bark thin, $\frac{1}{50}-\frac{1}{12}$ inch thick, in curved pieces, greyish brown externally, with scattered brownish warts (lenticels), faintly cracked longitudinally, inner surface pale brown, laminate. Fracture tough, with flat splinters. Taste, bitterish, slightly astringent.

CRANESBILL.

Syn.-Crowfoot, Alum root.

Parts used-Root, herb.

Action-Styptic, astringent, tonic. The root possesses the greater astringency. The infusion of $r$ ounce of herb in a pint of boiling water is useful in infantile cholera, diarrhœa, \&c. Adult dose, a wineglassful as required. The fluid extract of the root may be used to stop internal or external bleeding. It has a tonic and astringent action on the kidneys. An injection for leucorrhœa 
(whites) and for flooding is prepared by pouring a pint of boiling water upon I ounce each crushed Cranesbill and Bethroot. The clear liquid is injected twice a day.

Preparations-Fluid extract: Dose, $\frac{1}{2}-\mathrm{I}$ drachm. Geraniin: Dose, I-3 grains.

Distinctive character-Root about $\mathrm{I} \frac{1}{2}-2$ inches long, $\frac{2}{8}-\frac{8}{8}$ inch thick, dull brown, hard, knotty, with small protuberances. Fracture short, pale brown or reddish, with white dots. Taste, very astringent. Odour, none.

CRAWLEY ROOT. Corallorhiza odontorhiza, Nutt. N.O. Orchidacea.

Syn.-Coral Root, Dragon's Claw, Chicken Toe.

Part used-Root.

Action-Diaphoretic, sedative, febrifuge. Of great value in the treatment of all fevers, pleurisy, \&c., and may be relied upon in all cases to bring on free perspiration. As a warm infusion, of I ounce to a pint of boiling water, it may be taken as hot as bearable in doses of a small teacupful until perspiration is produced.

Preparation-Fluid extract: Dose, 15-30 drops.

Distinctive character-Small brown coral-like rhizome, in branched pieces, about I inch long and $\frac{1}{12}$ inch in thickness, with minute warts and transverse scars. Fracture short, greyish horny. Taste, sweetish then bitter. Odour, strong and peculiar when fresh. Very liable to attacks of mites if kept long.

CROSSWORT, ENGLISH. Galium Cruclata, Linn. N.O. Rubiacea. Syn.-Crosswort Bedstraw, Common Crosswort. Part used-Herb.

Distinctive character-Stem slender, about I- 2 feet long. Leaves, four in a whorl, elliptic-oblong, hairy. Flowers yellow, in small clusters, about eight together in the axils of the upper leaves. 
Syn.-Tiglium, Tiglium officinale, Klotzsch.

Part used-Oil expressed from seeds.

Action-Irritant, rubefacient, cathartic. Its action is prompt, and it frequently induces catharsis within an hour after taking. The sinallness of the dose makes it valuable where large quantities of medicine cannot be tolerated. It is frequently used with Castor Oil or it may be administered in capsules or pills. The dose is from a fraction of a drop to I drop. Externally Croton Oil is used for its counter-irritating and vesicant effects.

\section{Preparation-Liniment of Croton Oil, B.P.}

Distinctive character-Yellowish or reddish brown, rather viscid oil. Taste, burning acid. Odour, unpleasant. It should be classed with the poisons, as a dose of more than one drop internally is liable to prove dangerous. It can be separated by alcohol into a purgative portion which is not vesicatory, the portion soluble in alcohol containing the vesicatory and dangerous principle.

CUBEBS.

\section{Part used-Unripe fruit.}

Piper Cubeba, Linn. N.O. Piperacea.

Action-Aromatic, diuretic, expectorant. A valuable remedy in cases of gonorrhœa, gleet, catarrh, and internal inflammations. Also used in coughs, bronchitis, and lung troubles generally. Has a stimulating effect upon the mucous membranes. For gonorrhoa the oil is generally given in capsule form and in combination with Copaiba, Santal Oil, \&c.

Preparations--Powdered fruits: Dose, $\frac{1}{2}$-I drachm. Fluid extract: Dose, $\frac{1}{4}-1$ drachm. Oil: Dose, 5-30 drops. 
Oleoresin U.S.P.: Dose, 5-8 grains. Tincture B.P.: Dose, $\frac{1}{2}-I$ drachm. Lozenges U.S.P.

Distinctive character-The fruit resembles black pepper in size and colour, but always tapers suddenly below into a stalk, and the taste is not pungent but warm, aromatic, and rather turpentiny. The seed has a minute embryo in a small cavity at the apex. If genuine, the crushed fruit turns crimson with strong sulphuric acid. A spurious lind, with a nutmeg odour, does not give this colour and is liable to produce poisonous symptoms.

CUCKOOPOINT.

Arum maculatum, Linn. N.O. Aracea.

Syn.-Cuckoopint, Starchwort, Ramp, Lords-andLadies.

Part used-Root.

Action-Diaphoretic, expectorant. It is a good remedy internally and locally for sore throat. The dose is 10-30 grains of the powdered root. Large doses produce gastric inflammation, and fatal effects have been recorded from its use. It was formerly official in the Dublin Pharmacopœa.

Distinctive character-Root ovoid, about the size of a hazel nut, showing annular scars left by the leaf basis and scars of rootlets below. Internally white and starchy. Taste, acrid, lost to a certain extent on keeping. Odour, none. (See Wake Robin, American).

CUDWEED.

Gnaphalium obtusifolium, Linn. N.O. Composite. Syn.-Cottonweed, Gnaphalium polycephalum, Michx. Part used-Herb.

Action-Astringent. An excellent remedy for quinsy. The infusion of I ounce to a pint of boiling water should 
be taken internally in wineglassful doses, and also used as a gargle.

Preparation-Fluid extract : Dose, $\frac{1}{2}$ to I drachm.

Distinctive character-Stems and underside of leaves white, downy, with appressed woolly hairs. Leaves linear, about $\mathrm{I} \frac{1}{4}$ inch long and $\frac{2}{10}$ inch wide, not hairy above. Flowerheads in a corymb. Phyllaries linear, tapering, chaffy. Receptacle not hairy.

\section{CUP MOSS.}

Part used-Plant.
Cladonia pyxidata, Fries.

N.O. Lichenes.

Action-Expectorant. Is excellent for children's coughs and whooping coughs. A decoction is made of 2 ounces to a pint of water sweetened with honey.

Distinctive character-The scyphi or wine-glassshaped portions of the plant are used. They are greyish white, about I inch long, with a hollow stem $\frac{1}{1.6-\frac{1}{8}}$ inch in diameter, and a terminal cup about $\frac{1}{1}$ inch wide; the scyphi are sometimes proliferous. Taste, mucilaginous and slightly sweet. Odour, none. The plant is erroneously called a moss, as it belongs to the group of lichens.

CUP-PLANT.

Syn.-Indian Cup-plant, Ragged Cup.

Silphium perfoliatum, Linn. N.O. Composita.

Action-Tonic, diaphoretic, alterative. As a general restorative it has been found useful, also in fevers and spleen and liver affections. The decoction of the powdered root may be given in wineglassful doses, or the powder itself in 20-grain doses.

Distinctive character-Rhizome cylindrical, crooked, elongated, pitted and rough, with small roots; the transverse section exhibits large resin cells. 
DAMIANA.

Part used-Leaves.
Turnera aphrodisiaca, Willd. N.O. Turneracea.

Action-Aphrodisiac, diuretic, tonic. Is very largely prescribed on account of its aphrodisiac qualities, and there is no doubt that it has a very great general and beneficial action on the reproductive organs. It also acts as a tonic to the nervous system.

Preparations-Solid extract: Dose, IO-I 5 grains. Fluid extract : Dose, $\frac{1}{2}-\mathrm{I}$ drachm.

Distinctive character-Leaves alternate, linear, wedge-shaped, shortly stalked, hairy, about $\frac{3}{4}-\mathrm{I}$ inch long and $\frac{1}{8}-\frac{1}{4}$ inch broad, with a few serrate teeth, having recurved margins. Taste, bitter, aromatic, with a fig-like flavour.

DANDELION.

Taraxacum officinale, Weber. N.O. Composite.

Syn.-Taraxacum Dens-leonis, Desf., Leontodon Taraxacum, Linn.

\section{Part used-Root.}

Action-Diuretic, tonic, and slightly aperient. It is chiefly used in kidney and liver disorders, and is perhaps one of the most generally prescribed remedies. It may be given in any form, but its beneficial action is best obtained when combined with other agents. A pleasant way of taking it is in the form of a substitute for coffee. The roasted roots are ground and used as ordinary coffee, giving a beverage tasting much like the original article and certainly possessing more beneficial properties.

Preparations-Fluid extract B.P.: Dose, $\frac{1}{2}-2$ drachms. Leontodin: Dose, 2-4 grains. Solid extract B.P.: Dose, 5-15 grains. Juice B.P.: Dose, $1-2$ drachms. 
DEER'S TONGUE.

Liatris odoratissima, Willd. N.O. Orclidacea.

Syn.-Vanilla Leaf, Wild Vanilla, Trilisia odoratissima, Cass.

\section{Part used-Leaves.}

Action-Diuretic, stimulant, tonic.

Distinctive character-Leaves varying in size from the base of the plant upwards. Root leaves fleshy, 4-Io inches long, obovate-lanceolate, tapering below into a flattened stalk. Stem leaves oblong, clasping the stem at their base. The dried leaves have a strong odour of new mown hay.

\section{DEVIL'S BIT.}

Syn.-Of bit.

\section{Part used-Herb.}

Action-Diaphoretic, demulcent, febrifuge. Makes a useful tea for coughs, fevers, and internal inflammations. This remedy is generally given in combination with others. The infusion of $r$ ounce to a pint of boiling water is taken in wineglassful doses, frequently repeated.

Distinctive character-Leaves opposite, stalked, oval, lanceolate, with scattered one-celled tubular hairs, and nearly sessile, oval, several-celled glands. Florets purplish, with four lobes. Receptacle hairy. Stems often purplish.

DILL.

Peucedanum graveolens, Benth. N.O. Composita.

Syn.-Dill Seeds, Dill Fruits, Anetmum graveolens, Willd.

Part used-Dried ripe fruits.

Action-Carminative, stomachic. In children's complaints, such as flatulence, disordered digestion, \&c., it 
is an excellent remedy, mostly given in the form of Dillwater. The oil may also be administered in doses of $x-5$ drops on sugar.

Preparations-Dillwater: Dose, I- 8 drachms. Oil of Dill: Dose, I-5 drops.

Distinctive character-Fruits oval, compressed, winged, about $\frac{1}{10}$ inch wide, with three longitudinal ridges on the back, and three dark lines or oil cells (vittæ) between them, and two on the flat surface. Taste, aromatic, resembling caraway, but distinct. Indian Dill Seed is narrower and more convex, with paler, more distinct ridges, and narrower wings. The essential oil it contains is not identical with that of European Dill.

\section{DITA BARK.}

Syn.-Devil-Tree.

Part used-Bark.

Action-Febrifuge, astringent, tonic. Has some reputation as a remedy in dysentery, and has been employed with success in febrile complaints. Dose, I-4 drachms.

Distinctive character-In quilled pieces of varying size and thickness, from $\frac{1}{12}$ to $\frac{1}{3}$ inch thick. Outer surface rough, dark grey with whitish spongy patches. Inner surface dull yellowish white. The transverse fracture shows an outer layer darker than the inner, which is finely radiate. Taste, bitter. Odour, none.

DODDER.

Syn.-Lesser Dodder.

Cuscuta Epithymum, Murr. N.O. Convolvulacea.

Part used-Herb.

Action-Hepatic, laxative. Has been used in urinary complaints, kidney, spleen, and liver diseases. 
Distinctive character-Stem thread-like, curled and twisted, without leaves, but with small globular clusters of flowers, about $\frac{1}{8}$ - 1 inch in diameter at intervals. Taste, saline and slightly acrid. Odour, none.

DOG-ROSE.

Rosa canina, Linn. N.O. Rosacea.

Syn.-Wild Brier, Hip Tree, Cynosbatos.

Part used-Ripe fruit.

Use-A conserve made from the ripe fresh fruit has been official. It makes an excellent material for forming pillmasses. Now it is seldom used.

Preparation-Confectio Rosa Caninæ B.P., 1885 .

Distinctive character-Fruits oval, fleshy, hollow, scarlet when fresh, blackish when dried, with remains of the calyx teeth at the apex, seeds angular, whitish, densely covered with hairs. Taste of fruit, sweetish and acidulous.

DRAGON'S BLOOD.

Calamus Draco, Willd. N.O. Palmacere.

Syn.-Daemonorops Draco, Blume.

Part Used-Resin.

Action-Astringent, colouring. Its principal use is for colouring purposes in tooth powders, tinctures, plasters, \&c. Also for colouring in varnishes and wood stains, \&c.

Distinctive character-In lumps of a blackish red colour, or bright red where bruised or scraped, containing particles of the fruit scales. Taste, slightly acrid and sweetish. When heated it gives off irritating fumes of benzoic acid. About 70 per cent. soluble in spirits of wine, but it is only very sparingly in turpentine, and not in water. 
DYER'S GREENWEED-DWARF ELDER-ECHINACEA. 95

DYER'S GREENWEED. Gentista tinctoria, Linn.

N.O. Leguminosa.

Syn.-Greenweed, Dyer's Weed, Dyer's Broom, Woad-waxen.

Parts used-Twigs, leaves.

Action-Diuretic, cathartic, emetic. This plant has been successfully used as a remedy in dropsical affections, also in gout, rheumatism, and in albuminuria. The decoction may be given in wineglassful doses three to four times daily.

Distinctive character-Stems almost unbranched, about 6-8 inches long, angular, with erect linear-lanceolate, sessile, hairless leaves, about $\frac{3}{4}$ inch long and $\frac{8}{16}$ inch broad. Flowers, yellow, papilionaceous, in spikes terminating the stem. Taste, bitter. Odour, none.

DWARF ELDER.

Syn.-Danewort.

Part used-Leaves.
Sambucus Ebulus, Linn. N.O. Caprifoliacea.

Action-Expectorant, diuretic, diaphoretic, purgative. It is said to be very efficacious in dropsy. The berries are sometimes used medicinally.

Aistinctive character-Leaves pinnate, leaflets longer than those of the common elder, often with small stipulets at their base. Flowers white with pink anthers. Stem not woody. In the United States the name of Dwarf Elder is given to a different plant, viz., Aralia hispida, Vent. N.O. Araliacea.

ECHINACEA.

Syn.-Black Sampson, Coneflower.

Echinacea angustifolla, D.C. N.O. Composita.

Part used-Root.

Action-Alterative, antiseptic. Useful in all diseases due to impurities in blood, such as boils, carbuncles, 
gangrene, \&c., internally and externally. Is a good appetiser and improves digestion. Used in fermentative dyspepsia. Of special importance in typhoid and other fevers.

Preparation-Fluid extract: Dose, $\frac{1}{2}-\mathrm{I}$ drachm.

Distinctive character-Root greyish brown, externally more or less twisted, furrowed longitudinally, $\frac{1}{4}-\frac{1}{2}$ inch in diameter. The transverse section shows a thin brown bark, a yellowish porous wood in narrow wedges, with numerous slender black fibres which give a greyish appearance to the broken surface. Taste, slightly aromatic, bitterish, with a tingling sensation like Pellitory Root. Odour, none.

ELDER.

Sambucus nigra, Linn. N.O. Caprifoliacea.

Syn. - Black Elder, European Elder.

Parts used-Bark, flowers.

Action-Alterative, diuretic. An infusion of I ounce of bark or flowers in a pint of water is taken in wineglassful doses. Has been successfully employed in epilepsy.

Preparations-Fluid extract bark: Dose, $\frac{1}{2}$-I drachm. Water B.P.

Distinctive character-Bark light grey, soft and corky externally, with wide fissures, inner surface white and smooth. The transverse fracture shows a pale brown, outer portion in thin layers, and a thinner, white, finelyradiate, inner portion. Taste, sweetish at first, then bitter and nauseous. The flowers are wheel-shaped, small, with five oval obtuse segments, pale yellow when fresh, becoming of a pale brownish yellow when dried. Taste, mucilaginous. Odour, slight, but characteristic. 
Syn.-Scabwort, Aunée (Fr.)

Part used-Root.

Action-Diaphoretic, diuretic, expectorant. Is used principally in combination with other remedies for cough, consumption, and pulmonary disorders generally. It is also alterative and tonic. The decoction of I ounce to a pint of boiling water is taken in wineglassful doses.

Preparations-Powdered root: Dose, $\frac{1}{2}-\mathrm{I}$ drachm. Fluid extract: Dose, $\frac{1}{2}-\mathrm{I}$ drachm. Inulin: Dose, I-3 grains.

Distinctive character-Roots light grey, hard, horny, in cylindrical pieces of varying length, usually $\frac{1}{3} \cdot \frac{3}{4}$ inch in thickness, often attached to large sections of the crown of the root. The fracture is short, the transverse section shows a radiate structure, with numerous dark oil cells. Taste, aromatic, bitter, and acrid. The odour recalls that of Orris Root and Camphor. The root resembles that of Belladonna in colour and shape, but does not show a white surface when the epidermis is scraped as in Belladonna.

ELM.

Part used-Bark.
Ulmus campestris, Smit. N.O. Urticacea.

Action-Astringent, demulcent, diuretic.

Distinctive character-The inner bark only is used, deprived of the corky layer; it is in thin strips $\frac{1}{10}-\frac{1}{8}$ inch in thickness, externally of a rusty brown colour, and paler on the inner surface. Fracture laminate and fibrous. Taste, mucilaginous, astringent, and faintly bitter. Odour, none. 
EMBELIA.

Part used-Seeds.
Embelia Ribes, Burm. N.O. Myrsinacea.

Action-Tænicide, carminative, diuretic. Used by the East Indian natives in dyspepsia and rheumatic affections; but its reputation is due to its action of expelling tapeworms. The seeds in powder are given in doses of I-3 teaspoonfuls, with milk, upon an empty stomach and followed by a purgative.

Preparation-Fluid extract : Dose, I-4 drachms.

Distinctive character-The small globular fruits are about the size of white pepper, reddish brown, striated longitudinally, with a small beak at the apex. The single seed is horny with a mildewed appearance, due to a minute crystalline powder; at the base it has a cup-like hollow. Taste, astringent and aromatic. Odour, imperceptible.

The above description applies to Embelia robusta, which is always supplied in commerce under the name of E. ribes.

ERGOT.

Claviceps purpurea, Tul. N.O. Fungi.

Syn.-Ergot of Rye, Smut of Rye, Spurred Rye, Secale cornutum, Ness.

Part used-Fungus.

Action-Emmenagogue, hæmostatic, uterine stimulant. Largely used in menstrual disorders, as in leucorrhœa, dysmenorrhœa, amenorrhœa, for its stimulating action. Also an admirable remedy in hæmorrhage, flooding, intestinal bleeding, \&c. Of value in spermatorrhœa, gonorrhœa, and enlarged prostate.

Preparations-Fluid extract B.P.: Dose, I0-30 drops. Solid extract (Ergotin) B.P.: Dose, 2-8 grains. Tincture, ammoniated, B.P.: Dose, $\frac{1}{2}-\mathrm{I}$ drachm. Infusion B.P.: Dose, I-2 ounces. Wine U.S.P.: Dose, 2 drachms.

Distinctive character-The hard mycelium of the fungus known in commerce as Ergot, and formed at the 
expense of the grains of rye, is purplish externally, $\frac{1}{3}-1 \frac{1}{2}$ inch long, and $\frac{2}{16}-\frac{3}{16}$ inch in diameter, cylindrical, compressed, tapering, with rounded ends, and with a longitudinal fissure down each side. Fracture short and horny. Interior whitish, with a purple tinge towards the outside. Odour, disagreeable. Good Ergot should be brittle and show no signs of mites. It requires to be kept chemically dry, preferably in bottles having quicklime in a hollow stopper. The Spanish is larger than the Russian, and is more esteemed.

\section{ERYNGO.}

Syn.-Eringo, Seaholly.

Part used-Root.

Action-Diaphoretic, diuretic, expectorant. It is mostly used in uterine irritation, bladder diseases, painful micturition, with frequent and ineffective attempts to empty the bladder.

Distinctive character-Root $2-4$ inches long or more, transversely wrinkled, blackish brown, crowned with the bristly remains of leaf-stalks, sometimes branched above. Fracture spongy, and coarsely fibrous, with a small radiate yellow centre. Taste, sweetish, mucilaginous. Odour, none.

The root of the Seaholly, Eryngium maritinnm, is also sold under the name of Eryngo Root.

\section{ETERNAL FLOWER. Helichrysum Stoechas, D.C.} N.O. Composita.

Syn.-Gnaphalium Stoechas, Linn., Guaphalium citrinum, Lam., Stoechas citrina, Goldilocks.

Part used-Tops.

Action-Expectorant, deobstruent. Used in colds.

Distinctive character-Stem shrubby. Leaves linear, revolute at the margins, whitish, tomentose beneath and sometimes above. Flowerheads arranged in a crowded corymb, ovate, shortly stalked, with the 
outer scales of the involucre yellow and shining, ovate, rather acute. Taste, warm, pungent, bitterish. Odour, when rubbed, agreeable.

\section{EUCALYPTUS.}

Eucalyptus globulus, Labill.

Syn.-Blue Gum Tree.

N.O. Myrtacea.

Parts used-Leaves and oil distilled from leaves.

Action-Antiseptic, antispasmodic, stimulant. An Australian household remedy for many diseases and complaints. In England the oil is the preparation best known and most largely used. Its efficacy depends chiefly upon its antiseptic properties, which are extremely potent, though quite safe. In all fevers and febrile conditions the oil may be used freely externally and internally. It may be inhaled for asthma, diphtheria, sore throat, \&c.

As a local application for ulcers, \&c., I ounce should be added to I pint of lukewarm water. Its effect is stimulating, antiseptic, and corrective. For local injections, $\frac{1}{2}$ ounce to the pint is sufficient. Physicians report not only quick healing follows, but all offensive odours cease immediately. In this connection, it is most valuable as a local application in cancerous growths and wounds. Internally the Fluid Extract is used in scarlet, typhoid, and intermittent fevers, and the Oil is often applied to the body freely at the same time. In croup and spasmodic throat troubles it may be used in a similar way.

Preparations-Fluid extract: Dose, $\frac{1}{2}-\mathrm{I}$ drachm. Oil: Dose, 3-ro drops. Ointment B.P. Eucalyptol U.S.P.: Dose, 5 drops.

Distinctive character-The leaves are tough, leathery, greyish-green, scimitar-shaped (or, more rarely, when obtained from the younger leaves or shoots, ovate and stalkless); 4-6 inches long and about $\mathrm{I}-\mathrm{I} \frac{1}{2}$ inch wide in the centre, shortly stalked and rounded at the base, with numerous transparent oil dots. Taste, aromatic and cooling. Flavour, characteristic, somewhat camphoraceous. 
EUPHORBIA-EUPHORBIUM-EVENING PRIMROSE. IOI

EUPHORBIA.

Syn. -Asthma-weed, Cat's-hair.
Euphorbia pilulifera, Linn. N.O. Euphorbiacee.

Part used-Herb.

Action-Ant-asthmatic, pectoral. In Australia it is much esteemed as a remedy for coughs, bronchial and pulmonary disorders, but more especially for the prompt relief it affords in paroxysmal asthma. The infusion of $\frac{1}{2}$ ounce in a pint of boiling water is taken in tablespoonful doses.

Preparations-Fluid extract: Dose, I0-30 drops. Solid extract (alc.): Dose, I-2 grains.

Distinctive character-Stem slender, cylindrical, with bristly hairs and opposite leaves, which are lanceolate, about $\frac{3}{4}$ inch long and $\frac{3}{8}$ inch wide, and toothed at the margin. Flowers very small, in dense round clusters in the axils of the leaves. Seeds very small, reddish, oblong, angular, with a wrinkled surface. Taste, bitter. Odour, none.

\section{EUPHORBIUM.}

Euphorbia resinifera, Berg.

N.O. Euphorbiacea.

Distinctive character-In irregular pieces of a dull yellowish or brownish hue and waxy surface, usually about $\frac{1}{2}$ inch in diameter, often perforated where it has formed around the spines of the fleshy plant. Taste, extremely acrid and persistent. The dust excites violent sneezing and is dangerous to inhale.

EVENING PRIMROSE. Oenothera biennis, Linn.

Syn.-Tree Primrose.

N.O. Onagracea.

Parts used-Bark and leaves.

Action-Astringent, sedative. This drug has been tested in various directions, and Professor Scudder em- 
ployed it with success in the treatment of gastrointestinal disorders of a functional origin. It has also proved of service in dyspepsia, hepatic torpor, and in female disorders associated with pelvic fulness. The dose ranges from 5-30 grains.

Distinctive character-Leaves oblong-lanceolate, 3-5 inches long and I inch or more wide, pointed, nearly entire at the margins, and furnished with short hairs. Taste, mucilaginous and slightly astringent. Odour, none.

EYEBRIGHT.

\section{Part used-Herb.}

Action-Slightly tonic, astringent. Is employed principally as a remedy in diseases of the sight, weakness of the eyes, ophthalmia, \&c. Combined with Golden Seal it makes a most excellent lotion for general disorders of the eyes.

Preparation-Fluid extract: Dose, I drachm.

Distinctive character-Stems about 4-6 inches long, often branched below. Leaves opposite below, alternate above, about $\frac{1}{3}$ inch long and $\frac{1}{4}$ inch broad, lanceolate or nearly rhomboid above, with four to five teeth on each side. Flowers small, axillary, whitish, two-lipped, with a yellow throat and four stamens. Taste, saline, bitter, and slightly astringent.

FENNEL.

Part used-Seed.

Action-Stimulant, carminative, stomachic. Generally added to other medicines for flavouring purposes

Foeniculum dulce, D.C. N.O. Umbellifera. 
and used as a carminative, and as such it forms part of the well-known Compound Liquorice Powder.

Preparations-Fluid extract : Dose, 5-30 drops. Oil: Dose, I-5 drops. Water B.P. and U.S.P.: Dose, 4 drachms.

Distinctive character-The fruit is about if inch long and is inch broad, oblong, cylindrical and slightly curved. Each half-fruit has four longitudinal ridges, the two lateral thicker than the dorsal. Taste, sweetish, aromatic. Odour, similar. The colour varies from greenish to brownish according to age. Indian and German Fennel are usually rather smaller and straighter, and not quite so rounded at the ends. Persian and Japanese Fennel are the smallest, and have a sweeter taste, resembling Anise.

FENUGREEK. Trigonella Foenum-graecum, Linn.

Part used-Seeds.

N.O. Leguminosa.

Action-Emollient. Used externally as a poultice in abscess, boils, carbuncles, \&c. Internally a decoction of I ounce of seeds in a pint of water is used in inflamed conditions of stomach and intestines. Its chief use is as an ingredient in cattle and horse condiments. It also enters into curry powders.

Distinctive character-Seeds brownish yellow, about $\frac{1}{8}$ inch long, oblong rhomboid, with a deep furrow almost dividing the seed into two unequal lobes. Taste, recalling that of celery or Lovage. Odour, similar.

FEVERBUSH.

Garrya Fremontii, Torr. N.O. Cornacee.

Syn.-Skunkbush, California Feverbush.

Part used-Leaves.

Action-Tonic, bitter, antiperiodic. The leaves are used in California as a substitute for Peruvian Bark 
and for similar purposes. The dose is 10-30 grains of the powder.

Distinctive character-Leaves short-stalked, I-3 inches long and nearly as broad, leathery, greyish green, entire at the margins, often with a point at the apex. Taste, bitter. Odour, slight.

FEVERFEW. Chrysanthemum Parthenium, Bernh. N.O. Composita.

Syn. - Pyrethrum Parthenium, Sm. Featherfew, Featherfoil.

Part used-Herb.

Action-Aperient, carminative, bitter. It is largely used to promote the menses, expel worms, and in hysterical conditions. As an infusion of I ounce to a pint of boiling water, it is taken frequently in doses of half a teacupful.

Preparation-Fluid extract: Dose, I-2 drachms.

Distinctive character-Stem finely furrowed, hairy. Leaves alternate, downy with short hairs, or nearly smooth, about $4 \frac{1}{2}$ inches long and 2 inches broad, bipinnatifid, with serrate margins, the leaf stalk flattened above and convex beneath. Taste, bitter, nauseous. Odour, resembling that of tansy.

FIG.

Flcus Carica, Linn. N.O. Urticacea.

Part used-Fleshy inflorescence (so-called fruit).

Action-Nutritive, emollient, demulcent, laxative. The fresh and dried fruits are used in constipation, and they form part of the official Confection of Senna. Roasted figs have a place in domestic practice as a poultice for gumboils, boils and carbuncles. A poultice 
of dried figs in milk is said to remove unpleasant odours from ulcers and cancers.

Distinctive character-The fleshy inflorescence, or syconus, called a fig, contains the minute ovaries or socalled seeds, each of which is the result of one of the single female flowers with which the cavity is filled. The male flowers occupy the minute tubular orifice at the apex of the figs.

FIGWORT.

Scrophularia nodosa, Linn.

N.O. Scrophulariacea.

Syn.-Rosenoble, Throatwort, Carpenter's Square.

Part used-Herb.

Action-Diuretic, depurative, anodyne. This is called the Scrofula plant on account of its great value in all cutaneous eruptions, abscesses, wounds, \&c. The leaves should be applied as a poultice, and an infusion of I ounce to a pint of boiling water taken internally in half-wineglassful doses.

Preparation-Fluid extract: Dose, $\frac{1}{2}-1$ drachm.

Distinctive character-The herb has a square stem, opposite, stalked leaves, 4-5 inches long and $\mathrm{r} \frac{1}{2}-2$ inches broad, rounded, but unequal at the base and tapering to a point above, margins sharply but unequally serrate, the veins and veinlets prominent beneath and depressed above. Taste, bitter. Odour, narcotic. The knotty rhizome and acutely-pointed leaves distinguish this from the water figwort (S.aquatica.).

FIREWEED.

Erechtites hieracifolia, Rafin.

Parts used-Plant, oil. N.O. Composita.

Action-Astringent, alterative, tonic. Finds a use as a remedy in relaxed states of mouth and throat. The oil is antispasmodic, and recommended as such in spasms, colic, hiccough, and externally for piles. The 
oil is given internally in doses of 5-ro drops on sugar, in capsules or in emulsion. It forms a warming and pain-relieving, external application in rheumatic, sciatic, and gouty affections.

Distinctive character-Herb I-5 feet high. Stem fleshy, fluted, roughish. Leaves very variable in size and division, alternate, lanceolate-ovate to linear, with a short stalk divided in an irregularly and sharplytoothed manner or even bipinnatifid, the upper sessile and clasping. Flowerheads narrow, cylindrical, the outer scales short, spreading, the inner long and linear. The florets are very slender, the fruits oblong slender, crowned with silky pappus. The volatile oil has a sp. gr. of $0.838-0.855$ and a rotation of $-I^{\circ}$ to $+2^{\circ}$

FIVE-LEAF-GRASS.

Potentilla reptans, Linn.

Syn.-Cinquefoil, Fivefinger.

N.O. Rosacea.

Part used-Herb.

Action-Astringent, febrifuge. The infusion of I ounce of herb in a pint of boiling water is used in wineglassful doses for diarrhœa, looseness of bowels, \&c. Externally, as an astringent lotion.

Preparation-Fluid extract: Dose, $\frac{1}{2}-2$ drachms.

Distinctive character--Stem slender, creeping, with internodes 2.4 inches long or more, leafstalks I-2 inches long, with five leaflets, the central one free, the two lateral joined near the base, obovate-obtuse, bluntly serrate, about 2 inches across and $1 \frac{1}{2}$ inch long, with scattered hairs on the veins and margins, veins prominent below. Taste, astringent. Odour, none.

FIVE-LEAF-GRASS, AMERICAN:

Potentilla Canadensis, N.O. Rosacea.

Uses and properties similar to preceding one.

Distinctive character-Leaves with a whitish silky appearance, palmately cut, with obovate lobes wedge- 
shaped below, and deeply toothed. Stipules lanceolate, obtuse. Flowers yellow, on solitary stalks. Calyx fivetoothed, with linear lanceolate teeth nearly as long as the petals, which are orbiculate. Taste, astringent. Odour, none.

FLEABANE.

Erigeron Canadense, Linn. N.O. Composita.

Syn.-Canada Fleabane, Coltstail, Prideweed.

Parts used-Herb, seeds.

Action-Astringent, diuretic, tonic. Considered efficient in diarrhœa, gravel, and in many kidney affections. The infusion is very serviceable in such cases, given in doses of a wineglassful to a teacupful. It owes its virtues to a volatile oil.

Preparations-Oil: Dose, 2-5 drops. Fluid extract : Dose, $\frac{1}{2}$-I drachm.

Distinctive character-Stem unbranched, leaves oblanceolate and short-stalked below, with five teeth, upper becoming linear and entire, usually I-2 inches. Flowerheads numerous, bell-shaped, about $\frac{1}{6}$ inch long and broad, whitish, shorter than the involucre, receptacle naked, fruits (achenes) flat, with fine bristly pappus. Taste, astringent, aromatic and bitter. Odour, slight.

FLUELLIN.

Syn.-Toadflax, Flaxweed.

Part used-Herb.

Action-Astringent, hepatic, detergent. Is recommended as an alterative in jaundice, liver and skin diseases and scrofula. An ointment made from the fresh plant forms a good application for piles. An infusion of I ounce to a pint of water is taken in the usual way. 
FOOL'S PARSLEY.

Syn.-Dog Parsley, Dog Poison.

Part used-Herb.

Action-Stomachic, sedative. In gastro-intestinal troubles of infants this has been found very useful, also in cholera infantum, convulsions and summer diarrhœa.

Distinctive character-Leaves resembling those of Hemlock, but smaller, and the ultimate segments have brown points. The umbels have no general involucre, but the secondary umbels have three linear pendent bracts beneath each.

\section{FOXGLOVE.}

Syn.-Purple Foxglove.

Part used-Leaves.

Action-Cardiac tonic, sedative, diuretic. Used in cardiac complaints arising from kidney diseases, also in dropsy and urinary suppression. Owing to its cumulative action it should be used with great care. The infusion of I drachm in a pint of boiling water is taken in teaspoonful to tablespoonful doses.

Preparations-Powdered leaves: Dose, $\frac{1}{2}-2$ grains. Solid extract U.S.P.: Dose, $\frac{1}{5}$ grain. Fluid extract : Dose, I-3 drops. Tincture B.P.: Dose, 5-I 5 drops. Infusion B.P.: Dose, 2.4 drachms.

Distinctive character-Root leaves 8 or 9 inches long or more, and 3-4 inches broad, tapering below into a winged stalk, the veins running down into the winged part; veins at an acute angle to the midrib, prominent beneath, and depressed on the upper surface giving the leaf a reticulated surface. Hairs short, forming a densely velvety surface below, but more scattered above, those on the leafstalks long and silky. The margins irregularly crenate. Taste, very bitter. Odour of the dried leaves, tea-like. 
Syn.-Old-man's-beard, Snowdrop-tree.

Part used-Rootbark.

Action-Alterative, diuretic, tonic. Used in bilious and typhoid fevers. Is prompt and efficacious in liver derangements, and also in jaundice. In female disorders, useful in conjunction with Pulsatilla and other remedies. The infusion of I ounce to a pint of boiling water is taken in tablespoonful to wineglassful doses. Externally this is used as a lotion or injection.

Preparations-Fluid extract: Dose, 5-30 drops. Chionanthin: Dose, I-3 grains.

Distinctive character-The rootbark occurs in irregular quilled pieces $2-3$ inches long and about $\frac{1}{8}$ inch thick, externally dull brown with irregular concave scars, the inner surface quite smooth and bright buff. The transverse fracture short, pale buff colour, dense; the inner layer with projecting bundles of stone cells. Taste, very bitter. Odour, none.

FROSTWORT. Helianthemum Canadense, Michx. N.O. Cistacea.

Syn.--Rock Rose, Frostweed, Cistus Canadensis, Linn. Part used-Herb.

Action-Alterative, tonic, astringent. Internally it is used as a cure for scrofula. The infusion of $\mathrm{I}$ ounce to a pint of boiling water is taken freely in doses of a wineglassful. It is also used externally as a wash for ulcers, \&c.

Preparation-Fluid extract: Dose, $\frac{1}{2}-\mathrm{I}$ drachm.

Distinctive character-Twigs slender, purplish brown, with opposite leaf scars. Leaves linear, oblong, about $\frac{3}{8}-\frac{5}{8}$ inch long, greyish green, due to a whitish covering of tufted hairs; fertile apetalous flowers in 
small clusters. Fruit small, ovate, triangular, brown, polished, containing a few dull brown angular seeds. Taste, astringent and bitter. Odour, none.

FUMITORY.

Syn.-Earth Smoke.

Part used-Herb.

Action-Slightly tonic, diuretic, aperient. Used chiefly in stomach derangements, liver complaints, and in skin affections. The infusion may be freely taken in doses of a wineglassful every two to three hours.

Preparation-Fluid extract : Dose, $\frac{1}{2}$-I drachm.

Distinctive character-Stems angular. Leaves twice pinnate, the ultimate segments linear, obtuse or pointed, not hairy. Flowers slender, pink, in short spikes, irregular, with two bundles of three stamens each. Fruit globular, depressed, containing one seed. Taste, bitter, saline and unpleasant.

GALANGAL.

Alpinia officinarum, Hance. N.O. Zingiberacea.

Syn.-Galanga, East India Root.

Part used-Root.

Action-Carminative, stimulant. Is especially useful in dyspepsia, preventing fermentation and removing flatulence. The decoction of I ounce in a pint of boiling water may be taken in tablespoonful to wineglassful doses. The powder is used as a snuff.

Preparation-Fluid extract: Dose, $\frac{1}{2}-\mathrm{I}$ drachm.

Distinctive character-Rhizome dark reddish brown, cylindrical, about $\frac{1}{2}-\frac{3}{4}$ inch in diameter and $\mathrm{r} \frac{1}{2}-3$ inches long, marked at short intervals with 
raised rings or scars of leaf bases. Fracture hard and tough. The transversely cut surface is paler than the outside with a darker central column. Taste, pungent and spicy. Odour, agreeable, recalling that of ginger.

GALBANUM. Ferula galbaniflua, Boiss. et Buhse. N.O. Umbellifera.

Syn.-Gum Galbanum.

Part used-Gum-resin.

Action-Stimulant, resolvent. It has been used internally in hysteria, rheumatism, chronic affections of mucous air passages, and is given in doses of 10-30 grains, mostly in emulsion. Externally it forms part of plasters and ointments.

Distinctive character-The gum resin is usually formed of an agglomeration of tears, some of which are translucent, and pale bluish green, and are intermixed with transverse sections of the root. The finest kind, not often obtainable, occurs in friable masses of loosely agglomerated, yellowish or brownish, small tears, opaque and yellowish white internally, with a slight musky as well as turpentiny odour, the latter odour prevailing in the commoner kind. A piece of Galbanum immersed in water will give a blue fluorescence, if a drop of liquid ammonia is added, indicating the presence of umbellifehone.

GALE, SWEET.

Syn.-Dutch Myrtle.

Part used-Shrub.

Action-Aromatic, astringent.

Distinctive character-Stem shrubby. Leaves leathery, lanceolate-obovate, about $\mathrm{I}$ inch long and 
$\frac{1}{2}$ inch wide, furnished with small resinous glands. Taste, aromatic, astringent. Odour pleasant, distinctive, recalling that of bay leaves.

GALLS.

Quercus Lusitanica, Lam. N.O. Hymenoptera.

Syn.-Nutgalls.

Part used-Excrescences on Quercus infectoria, Oliv., by the insect $C$ ynips Galla-tinctoria, Oliv.

Action-Astringent. Have been used in dysentery, diarrhœa, cholera, and passive hæmorrhages, \&c. As an injection in gonorrhœa, gleet, leucorrhœea, \&c., the infusion may be used. Also as a gargle in relaxed throat.

Preparations-Powdered gall: Dose, 5-20 grains. Fluid extract: Dose, 5-20 drops. Tincture U.S.P.: Dose, I drachm. Ointment B.P. Comp. Ointment B.P.

Distinctive character-The Aleppo Oak Galls are spherical from $\frac{4}{10}-\frac{8}{10}$ inch in diameter, smooth, but furnished in the upper half with small pointed knobs, in an irregular zone, bluish or olive green, and heavy if the insect has not escaped, but perforated near the middle with a round hole, and yellowish brown in colour and lighter in weight when it has done so. Taste, very astringent, and slightly acid, afterwards sweet. Odour, none.

GAMBOGE.

Garcinia Hanburil, Hook. f. N.O. Clusiacea.

Syn.-Camboge, Gutta Cambodia, Gutta Gamba, Garcinia Morella, Desr.

Part used-Gum-resin.

Action-Purgative. Is seldom employed alone, but acts well and safe in combination with cathartics, and 
is useful wherever such are needed, as it reinforces their action.

Distinctive character-The gum-resin is imported in the form of cylindrical sticks 4.8 inches long and I-2 $\frac{1}{2}$ inches in diameter, bearing the striated markings of the interior of bamboo in which it is collected. The transverse fracture, if the gamboge is of good quality, is clean and smooth, not gritty, deep orange brown, and opaque. Rubbed with water it gives a yellow emulsion. Fracture conchoidal. Taste, very acrid. The powder excites sneezing.

GARLIC.

Part used-Bulb.

Action-Diaphoretic, diuretic, expectorant. Garlic juice is made into a syrup with honey or sugar and given with advantage in coughs, colds, and asthma.

Preparations-Juice: Dose, I0-30 drops. Syrup: Dose, I drachm. Tincture: Dose, $\frac{1}{2}-I$ drachm.

Distinctive character-The bulb of garlic is compound, containing, between membranous scales, a number of smaller bulbs or "cloves." Taste, like onions, but much stronger.

GELSEMIUM.

Gelsemium nitidum, Mich.

N.O. Loganiacea.

Syn.-Gelsemium sempervirens, Pers., Yellow Jasmine, Wild Woodbine.

Part used-Root.

Action-Arterial sedative, diaphoretic, febrifuge, antispasmodic. In small doses allays nervous excitement and irritation. Used in inflammation of bowels, diarrhœa, dysentery, but with great success in neuralgia, toothache, insomnia, wherever a sedative is called for. In pelvic 
disorders of women it is a favourite remedy. In large doses it depresses the nervous system and gives rise to convulsions and toxic symptoms.

Preparations-Fluid extract U.S.P.: Dose, 5-10 drops. Solid extract: Dose, I-2 grains. Tincture B.P. : Dose, 5 -I 5 drops. Gelsemin : Dose, $\frac{1}{2}-2$ grains.

Distinctive character-The root is often mixed with the underground stem, the latter distinguished by its distinct pith, the straight form, and the purplish, longitudinal lines on the bark. The root is usually more or less tortuous, brown and smooth, with a thin bark and woody centre composed of porous woody wedges, and rather broad medullary rays. Fracture, short and woody, showing in the bark a few thin projecting silky fibres. Taste, slightly bitter. Odour, faintly aromatic.

GENTIAN.

Part used-Root.

Action-Tonic. Deservedly the most popular of tonic medicines. Being a simple bitter it may be given in all cases of weakness of digestive organs, general debility, female weakness, hysteria, \&c.

Preparations-Fluid extract: Dose, $\frac{1}{2}$-I drachm. Compound infusion B.P.: Dose, $\frac{1}{2}-1$ ounce. Compound tincture B.P. and U.S.P.: Dose, $\frac{1}{2}-1$ drachm. Solid extract B.P.: Dose, 2.8 grains.

Distinctive character-The root is cylindrical, brown, I foot or more in length, or broken up into shorter pieces, usually $\frac{1}{2}-\mathrm{I}$ inch thick, the upper portion marked with numerous rings, the lower longitudinally wrinkled, tough and flexible, internally of an orange brown tint, uniformly spongy. Taste, very bitter. Odour, strong and distinctive. 
GENTIAN, ENGLISH. Gentiana campestris, Linn. N.O. Gentianacea.

Syn.-Felwort, Baldmoney, Field Gentian.

Parts used-Root, herb.

Action-Bitter tonic. For uses see Gentian.

Distinctive character-Herb, 4-6 inches high, branched above, leaves opposite, ovate-lanceolate, or ovate-spathulate below, with entire margins. Flowers bluish purple, tubular, with five segments. Calyx segments five, nearly equal. Taste, bitter. Odour, none.

GERMANDER.

Teucrium Chamaedrys, Linn. N.O. Labiata.

Syn.-Chasse fiévre (Fr.), Petit Chêne (Fr.).

Part used-Herb.

Action-Stimulant, tonic, diaphoretic, diuretic. Has been employed in rheumatism, gout, intermittent fevers, scrofula, and skin diseases. See Water Germander.

Distinctive character-Stem I-2 feet long. Leaves dark green, shining above, ovate, $\frac{1}{2}-1 \frac{1}{4}$ inch long and $\frac{1}{4}-\frac{1}{2}$ inch broad, with oblong, obtuse teeth and a wedgeshaped entire base. Floral leaves nearly entire. Flowers purplish red, upper lip deeply bifid, with projecting stamens. Taste, bitter. Odour, none.

GINGER.

\section{Part used-Root.}

Action-Stimulant, carminative, expectorant. Is chiefly used in combination with other remedies, but should be taken alone in cases of colds, spasms, flatu- 
lence, \&c., in doses of 10-20 grains in warm water sweetened.

Preparations-Fluid extract: Dose, Io-20 drops. Tincture B.P.: Dose, $\frac{1}{2}-\mathrm{I}$ drachm. Syrup B.P. and U.S.P.: Dose, $\frac{1}{2}$-I drachm. Oleoresin U.S.P.: Dose, $\frac{1}{2}$ grain.

Distinctive character-The rhizome as imported is usually about 3 inches long and laterally branched, the branches more or less compressed, oval and contracted below, depressed at the rounded end. Fracture pale buff, starchy and fibrous, sometimes horny. Taste, pungent and aromatic. Odour, characteristic.

\section{GINGER, WILD.}

Asarum Canadense, Linn. N.O. Aristolochiacea.

Syn.-Indian Ginger, Canada Snakeroot.

Part used-Rhizome.

Action-Expectorant, carminative, stimulant. As a carminative it is useful in all painful spasms of the bowels and stomach. In colds or in amenorrhoea from cold it is a valuable stimulant. The infusion of $\frac{1}{2}$ ounce of the powdered root in a pint of boiling water produces copious perspiration, when taken hot. The powder may be taken dry in doses of 20-30 grains.

Distinctive character-Rhizome slender, about 4 inches long and $\frac{1}{8}$ inch thick, quadrangular or almost twoedged, wrinkled, greyish or purplish brown. Fracture short, whitish rootlets about $\frac{1}{2}$ inch distant on the nodes, scarcely branched. Taste, bitterish and pungent and aromatic. Odour, aromatic.

GINSENG.

Panax quinquefolium, Linn. N.O. Avaliacea.

Syn.-Avalia quinquefolia, Decne. and Pl.

Part used-Root.

Action-Tonic, stimulant. Useful in loss of appetite, stomach and digestive affections, arising from mental 
and nervous exhaustion. The Chinese ascribe wonderful medicinal virtues to it.

Distinctive character-Root spindle-shaped, pale brownish yellow, 2-3 inches long, and about $\frac{1}{2}$ inch in diameter, ringed above, divided into two or three equal branches which are wrinkled longitudinally. Fracture short, white, mealy with a thin bark containing numerous reddish resin cells; wood wedges narrow, yellowish, medullary rays broad. Taste, sweetish and faintly aromatic. Odour, imperceptible.

GLADWIN.

Syn.--Stinking Gladwyn, Gladwine.

Part used-Root.

Action-Antispasmodic, cathartic, anodyne. Occasionally used as a purgative; said to relieve cramps, convulsions and pains, stomachic and rheumatic.

GLEDITSCHIA.

Gleditschia triacanthos, Linn. Syn.-Gleditschia Ferox, C. Koch.

NO. Leguminosa.

Parts used-Leaves and twigs.

Action-Narcotic, anodyne, mydriatic. An alkaloid " gleditschine," also named "stenocarpine," was introduced in the end of the '7o's as a local anæsthetic and mydriatic. Since then very little has transpired about its properties and uses.

GOA POWDER.

Andira Araroba, Aguiar. N.O. Leguminosa.

Syn.-Araroba, Bahia Powder, Brazil Powder, Ringworm Powder, Chrysarobine, Vouacapona Avavoba, Druce.

Action-Tænifuge, alterative, detergent. It is used occasionally in the Indies for tapeworm. European 
medical men use it because of its chrysophanic acid, in skin diseases, such as eczema, psoriasis, acne, \&c. The powder is mixed with vinegar, lemon juice, or glycerine to form a paste and applied to the slin. It is also used in form of a paint or ointment.

\section{Preparation-Ointment B.P.}

Distinctive character-Goa powder, when recently imported, has a greenish yellow tint, and is mixed with ochreous yellow lumps, and pieces of the wood of the tree from which it is obtained, but when ground it has a brownish yellow tint which gradually darkens if exposed to damp, ultimately to a deep purplish brown tint. It is not soluble in water, but is in benzol or petroleum spirit, and in ammonia; it should yield 60.80 per cent. soluble in those solvents. In ammonia it gives a brownish red solution. Taste, very bitter. The powder is very irritating to the nose and eyes and mucus membranes generally.

GOAT'S RUE.

Part used-Herb.
Galega officinalis, Linn. N.O. Leguminosa.

Action-Stimulant, diuretic, vermifuge.

Distinctive character-Stem branched. Leaves pinnate, $\frac{3}{4}-2$ inches long, with six to eight pairs of lanceolate leaves and a terminal one, each furnished with a terminal point (mucro). Stipules half-arrow-shaped. Flowers pale purplish or white, in axillary racemes. Legumes almost cylindrical. Taste, bitter and astringent. Odour, none.

GOLD THREAD.

Coptis trifolia, Salisb. N.O. Ranunculacere.

Syn.-Mouth Root, Vegetable Gold.

Part used-Root.

Action-Bitter tonic. Would be more used than it is, if its good qualities were better known. It may be 
given alone or in combination with other suitable medicines. It promotes digestion, improves the appetite, and acts as a general stimulant to the system. In convalescence it is highly beneficial.

Preparations-Powdered root: Dose, I0-20 grains. Fluid extract: Dose, $\frac{1}{4}-\mathrm{I}$ drachm.

Distinctive character-Rhizomes thread-like, golden yellow, matted, with very small roots. Leaves stalked, tufted, with slender stalks, evergreen, strongly veined, three parted, with obovate cuneate segments and crenate, pointed teeth. Taste, very bitter. Odour, slight.

GOLDEN ROD.

\section{Part used-Leaves.}

Solidago Virgaurea, Linn. N.O. Composita.

Action-Aromatic, carminative, stimulant. Allays sickness due to weakness of stomach, and also promotes perspiration. The infusion of I ounce to a pint of boiling water is taken in wineglassful doses, repeated frequently.

Preparation-Fluid extract: Dose, $\frac{1}{2}-1$ drachm.

Distinctive character-Stem somewhat angular. Leaves lanceolate and stalked near the root, narrower on the stem, $2 \frac{1}{2}-3 \frac{1}{2}$ inches long and $\frac{3}{4}$-I inch broad, sometimes slightly toothed and undulated at the margin, with very short hairs. Flowerheads golden yellow, narrow, about $\frac{1}{4}-\frac{1}{3}$ inch long, receptacle honeycombed, pappus hairy not feathery. Taste, acrid and bitter. Odour, when dry, agreeable, slightly aromatic.

GOLDEN SEAL.

Syn.-Orange Root, Yellow Root.

Part used-Root.

Action-Tonic, laxative, alterative, detergent. Since about 1847 Golden Seal has figured conspicuously in 
the botanic practice. The name was given to this plant by Thomsonians, who employed the root. The demand for "concentrations" was the means of discovering the two alkaloids contained in this drug-Hydrastine, the white, and Berberine, the yellow-besides others of less value. For many years these and the powdered root were the chief forms administered. Latterly, however, the drug in the form of a fluid extract is the most used and popular. It is a very valuable remedy in disordered states of the digestive apparatus. As a general bitter tonic it is applicable to debilitated conditions of mucuous tissues. As a remedy for various gastric disorders it takes a leading place, acting very beneficially in acute inflammatory conditions. It will be found of value in all cases of dyspepsia, biliousness and debility of the system. It is especially indicated in catarrhal states of the mucous membranes, gastric irritability, and passive hæmorrhages from the pelvic tissues. In the second stage of gonorrhœa it should be used as an addition to other injections. Externally it is used as a lotion in treatment of eye affections and as a general cleansing application.

Preparations-Powdered root: Dose, Io grains or more. Fluid extract: Dose, $\frac{1}{4}-\mathrm{I}$ drachm. Hydrastine, Berberine. Tincture B.P. and U.S.P.: Dose, $\frac{1}{2}-I$ drachm. Solid extract: Dose, 5-8 grains.

Distinctive character-The rhizome is short, about $\mathrm{I} \frac{1}{2}$ inch in length, knotty with the bases of stems, and about $\frac{1}{8}-\frac{1}{4}$ inch in diameter, often furnished with abundance of rootlets. Fracture greenish yellow, showing a radiate woody centre, with broad medullary rays. Taste, very bitter. Odour, strong and disagreeable.

GOUTWORT.

AEgopodlum Podagraria, Linn. N.O. Umbellifera. Syn.-Goutweed, Ashweed, Ground Ash, HerbGerarde.

Part used-Herb. 
Action-Diuretic, sedative. Recommended internally for aches in joints, gouty and sciatic pains. Also used externally as a fomentation.

Distinctive character-Leaves with long stalks, divided once or twice into three-stalked leaflets, which are about 2 inches long and about $I_{1}^{\frac{1}{4}}$ broad, have unequal sides, are acutely pointed, and are twice serrate at the margin; the veins are at an acute angle and prominent beneath. Leafstalks channelled above, and keeled beneath. Root creeping. Taste, saline. Odour, none.

GRAVEL ROOT. Eupatorium purpureum, Linn. N.O. Composita. Syn.-Gravelweed, Queen of the Meadow Root. Part used-Root.

Action-Diuretic, stimulant, tonic. Used principally in the treatment of gravel, stone in the bladder and affections of the kidneys and urinary organs. It is also a nervine tonic.

Preparation-Fluid extract: Dose, $\frac{1}{2}-\mathrm{I}$ drachm.

Distinctive character-Rhizome $\frac{1}{2}-\mathrm{I}$ inch in diameter, very hard and tough, with a thin greyish brown bark and thick whitish wood, not visibly porous, often hollow in the centre, and with wide medullary rays. The rhizome has short lateral branches, all furnished with crowded, tough woody roots, about $\frac{1}{12}$ inch in diameter, and several inches long. Taste, bitter, astringent, and slightly acrid.

GRINDELIA.

Grindelia camporum, Greene. and $G$. squarrosa, Dunal. N.O. Composita.

Syn.-Grindelia robusta, Nutt., Gum Plant, Hardy Grindelia, Scaly Grindelia.

Part used-Herb.

Action-Ant-asthmatic, diuretic, tonic. Very largely employed in America in the treatment of asthmatic and 
bronchial affections, also in whooping cough and kidney diseases. In asthma, \&c., it reduces the violence and frequency of the paroxysm. Guy's Hospital uses a mixture of Fl. ext. Grindelia $\frac{1}{2}$ drachm, Fl. ext. Liquorice I drachm, mucilage to I ounce.

Preparations-Fluid extract: Dose, ro-30 drops. Solid extract: Dose, I-I 5 grains.

Distinctive character-Grindelia in commerce consists of the flowering stems of G. camporum, Greene, formerly referred to Grindelia robusta, Nutt., and of $G$. squarrosa, Nutt. The leaves in the former are broad, and in the latter narrowed at the base, leathery, brittle, serrated at the margins, veins at an acute angle, not very prominent below, lanceolate, about $2 \frac{1}{2}-4$ inches long and $\frac{1}{2}-\mathrm{I}$ inch broad, not hairy. Flowerheads globular, about $\frac{3}{4}$ inch in diameter, with yellow florets, without hairy pappus, scales of the involucre reflexed, linear, pointed. Taste, aromatic, bitterish. Odour, slight.

GROUND IVY.

Glechoma hederacea, Linn. N.O. Labiata.

Syn. -Gill-go-over-the-ground, Alehoof, Haymaids, Nepeta glechoma, Benth.

\section{Part used-Herb.}

Action-Astringent, diuretic, tonic. Useful in kidney diseases and for indigestion. Also used as an antiscorbutic. Combined with Yarrow or Chamomile Flowers it makes an excellent poultice for abscesses, gatherings and tumours. The infusion of $\mathbf{I}$ ounce in a pint of boiling water is taken in wineglassful doses.

Preparation-Fluid extract: Dose, $\frac{1}{2}-\mathrm{I}$ drachm.

Distinctive character-Stem quadrangular, unbranched, 6 or more inches long, with stalked, opposite, somewhat kidney-shaped leaves deeply and obtusely crenate at the margins, paler and gland-dotted beneath, 
with many-celled hairs. Flowers blue, two-lipped, three or four together in the axils of the upper leaves, which often have a purplish tint. Taste, bitter and acrid. Odour, strong, aromatic.

\section{GROUND PINE, EUROPEAN.}

Ajuga Chamaepitys, Schreb.

Part used-Leaves.

N.O. Labiata.

Action-Stimulant, diuretic, emmenagogue. Forms a good remedy, combined with other suitable herbs for gout and rheumatism. Also useful in female disorders. The infusion of I ounce to a pint of boiling water is taken in tablespoonful doses, frequently repeated.

Preparation-Fluid extract: Dose, $\frac{1}{2}-2$ drachms.

Distinctive character-Herb bushy, 3-6 inches high, very hairy, with deeply trifid leaves having linear entire segments, with single flowers in the axils of the leaves. Corolla yellow, with dark spots. Lower leaves lanceolate, scarcely divided. Taste and odour, aromatic and turpentiny.

\section{GROUND PINE, AMERICAN.}

Lycopodium complanatum, Linn.

$\mathrm{N}, \mathrm{O}$. Lycopodiacea.

Distinctive character-Stem long, creeping, yellowish green, scaly, about $\frac{1}{12}$ inch diameter, giving off at intervals erect, fan-shaped forked branches, with minute, scale-like leaves, leaving only the sharp tips free, the branches bearing fructification in the form of a stalked tuft of four to five cylindrical spikes consisting of spore cases in the axils of minute bracts. Stem rooting below at long intervals, the roots pale, wiry, and slightly branched. Taste, slightly turpentiny. Odour, aromatic.

Properties similar to the foregoing. 
GROUNDSEL.

Syn.-Groundsel.
Senecio vulgaris, Linn. N.O. Composita.

Part used-Herb.

Action-Diuretic, diaphoretic. Relieves bilious pains and in a strong infusion acts as a purgative and an emetic.

Distinctive character-Stem angular, branched. Leaves oblong, wider and clasping at the base, with short lateral angular-toothed lobes. Flowerheads about $t$ inch long and $\frac{1}{8}$ inch broad, cylindrical, with black-tipped linear, involucral scales. Florets all tubular, receptacle dotted, not hairy. Taste, saline. Odour, none.

GUAIACUM.

Guaiacum officinale, Linn. and Gualacum sanctum, Linn. NO. Zygophyllacea.

Syn.-Lignum Vitæ, Lignum Sanctum.

Parts used-Wood and resin.

Action-Diaphoretic, alterative. Is considered a valuable remedy in gout, chronic rheumatism, impurities of the blood, \&c. It is generally used in conjunction with Sarsaparilla and enters into most blood-purifying compounds. The dose of the infusion (of wood) of I ounce to a pint of boiling water is a wineglassful.

Preparations-Fluid extract: Dose, $\frac{1}{4}-\mathrm{I}$ draclım. Tincture B.P. and U.S.P.: Dose, $\frac{1}{3}-\mathrm{I}$ drachm. Ammoniated tincture B.P. and U.S.P.: Dose, $\frac{1}{2}-1$ drachm. Resin: Dose, 5-I 5 grains. Mixture B.P.: Dose, $\frac{1}{2}-\mathrm{I}$ ounce. Lozenges B.P.

Distinctive character-The wood is usually sold in shavings or raspings. The heart wood, of a dark greenish brown, is heavy and sinks in water; it has an aromatic and irritating taste. Odour, slightly aromatic when rubbed or warmed. 
Syn.-Brazilian Cocoa, Uabano, Uaranazeiro, Paullinia sorbilis, Mart.

Part used-Seeds.

Action-Nervine tonic, stimulant. This drug owes its properties to the Caffeine it contains, and for this reason will be found serviceable in most cases of headache, particularly those caused by menstrual derangements. Its action is in some cases diuretic, and as such it finds use in rheumatic complaints and lumbago. Dose, 5-30 grains.

Preparation-Fluid extract U.S.P.: Dose, $\frac{1}{2}$ drachm.

Distinctive character-Usually in cylindrical rolls, about $\mathrm{I}_{2}$ inch thick and several inches long, formed of the broken seeds beaten into a paste and dried. Taste, astringent and bitterish, then sweet. Odour, recalling that of chocolate.

\section{HAIR CAP MOSS.}

Polytrichum Juniperinum, Willd. N.O. Musci.

Syn.-Bearsbed, Ground Moss, Robinsrye.

Part used-Plant.

Action-Diuretic. Possessing but very little smell and taste, it produces no disagreeable sensations. It is a very valuable and important remedy in dropsy, urinary obstruction and suppression. The infusion is taken in wineglassful doses.

Distinctive character-Stems slender, unbranched, 2-3 inches long, with small short awl-shaped, red-tipped leaves, overlapping, and crowded in the upper part of the stem. Fruit stalks when present terminating in a cylindrical, four-angled capsule containing spores. 
Syn. - White Leaf, Silver Leaf.

N.O. Rosacere.

\section{Part used-Leaves.}

Action-Bitter, tonic, astringent. Should be freely used in cases of cholera, diarrhœa, and bowel complaints after inflammations have abated. It is also used as a tonic and astringent injection in female complaints. The decoction is made from I ounce of leaves boiled in a pint of water, and is taken in doses of one or two wineglassfuls.

Preparation-Fluid extract: Dose, $\frac{1}{2}-I$ drachm.

Distinctive character-Leaves I-2 inches long and $\frac{3}{4}-\mathrm{x} \frac{1}{2}$ inch broad, irregularly and coarsely serrate, smooth above, woolly and white, or rusty beneath. Taste, astringent, slightly bitter. Odour, none.

HARTSTONGUE. Scolopendrium vulgare, Sym. N.O. Filices.

Syn.-Asplenium Scolopendrium, Linn., Phyllitis Scoloperdrinom, Greene.

\section{Part used-Herb.}

Action-Diuretic, laxative, pectoral. Specially recommended for removing obstructions from the liver and spleen, also for removing gravelly deposits in the bladder. The decoction is made of 2 ounces to a pint of water. Dose, a wineglassful.

Distinctive character-Fronds stalked, about $x \frac{1}{2}-2$ feet long and about $I \frac{1}{2}-2$ inches wide, with transverse simple veins, and linear sori of spore-cases, $\frac{1}{2} \cdot \frac{3}{1}$ inch long, in transverse series at the back. Taste, unpleasant. Odour, none. 
HAWTHORN.

Crataegus Oxycantha, Linn.

Syn.-English Hawthorn, Haw.

N.O. Rosacea.

Part used-Fruit.

Action-Cardiac, tonic. This drug is claimed to be a curative remedy for organic and functional heart disorders such as dyspnœa, rapid and feeble heart action, hypertrophy, valvular insufficiency, and heart oppression. The dose $\cdot$ is from 2-I5 grains three to four times a day

Preparation-Fluid extract: Dose, IO-I 5 drops.

HEARTSEASE.

Syn.-Wild Pansy.

Part used-Herb.
Viola tricolor, Linn. N.O. Violacece.

Action-Diaphoretic, diuretic. Used in blood disorders and in catarrhal affections. Its chief use is for moist cutaneous eruptions in children. Said to prevent convulsions in asthma and epilepsy.

Distinctive character-Leaves ovate-lanceolate, crenate, with pinnatifid stipules. Flowers violet-like, white, the corolla shorter than the spurred calyx. Fruit of three carpels. Taste, insipid. Odour, herbaceous.

HEDGE-HYSSOP.

Parts used-Root, herb.

Action-Diuretic, cathartic, emetic. In doses of 5-20 grains it has been recommended in chronic affections of the liver, jaundice and enlargement of spleen. It has also shown itself valuable in dropsical affections in doses of 15-30 grains. Large doses induce vomiting and purging. The infusion of $\frac{1}{2}$ ounce of powdered root in a pint of boiling water is given in tablespoonful doses. 
Distinctive character-Stem quadrangular, not hairy. Leaves opposite, not stalked, lanceolate, about I $\frac{1}{4}$ inch long and $\frac{1}{5}$ inch broad, with three to five longitudinal veins, and toothed at the margin above the middle. Flowers irregular, singly in the upper axils, pinkish, with five stamens of which only two are fertile. Taste, acrid and bitter. Odour, none.

The root is cylindrical, brownish yellow, about $\frac{1}{6}$ inch in diameter, with joints $\frac{1}{8}-\frac{1}{2}$ inch long, having ovate scales on the joints, with slender rootlets below. The transverse section shows a porous white bark, and a small, dense, yellowish woody ring, enclosing a comparatively large pith. Taste, very bitter. Odour, none.

HELLEBORE, AMERICAN. Veratrum viride, Sol. N.O. Liliacea.

Syn.-Swamp Hellebore, Green Hellebore, Itchweed, Indian Poke.

Parts used-Rhizome, root.

Action-Cardiac depressant. A useful remedy in febrile and inflammatory affections of respiratory organs, and used as a gargle in sore throat. For acute tonsillitis it is an excellent remedy. It relieves irritation of the nervous system, and is of special value in convulsions, mania, neuralgia, and headache. Porson.

Preparations-Powdered root: Dose, 4-Io grains. Fluid extract: Dose, I-2 drops. Tincture U.S.P.: Dose, 15 drops.

Distinctive character-The rootstock is blackish grey, obconical, 2-3 inches long and $\frac{3}{4}-\mathrm{I} \frac{1}{2}$ inch in diameter, tufted above with the scaly remains of stem leaves, internally whitish, with darker wavy lines and dots in the central portion, with numerous yellowish brown shrivelled rootlets, about 8 inches long and $\frac{1}{8}$ inch thick, having a brown nucleus sheath enclosing a fibrovascular cord. Taste, bitter and very acrid. Odourless, but the powder very irritating to the nostrils. 
HELLEBORE, BLACK.

Syn.-Christmas Rose.
Helleborus niger, Linn.

N.O. Ranunculacee.

Parts used-Rhizome, root.

Action-Diuretic, cathartic, emmenagogue. Has been used in dropsy, chlorosis and amenorrhœea. In nervous disorders, hysteria, and melancholia it is of value. Should be given in minute doses only, as larger ones cause untoward effects.

Preparations-Fluid extract: Dose, 2-10 drops. Solid extract: Dose, I-2 grains.

Distinctive character-Rhizome blackish, mostly forming an entangled mass of very short branches, and straight, rather brittle, black rootlets $\frac{1}{10}$ inch in diameter, which exhibit a central slightly angular cord. Transverse section of the rhizome shows a thick bark and a ring of whitish woody wedges. Taste, bitter and slightly acrid. Odour, slight, fatty.

HELLEBORE, FALSE.

Adonis vernalis, Linn.

N.O. Ranunculacea.

Syn.-Adonis, Pheasant's eye.

Part used-Herb.

Action-Cardiac tonic, diuretic. Is not cumulative in its action, but should be used with caution. Highly spoken of in heart diseases and kidney affections. Valuable in cardiac dropsy and heart strain. The dose of an infusion of $\frac{1}{4}$ ounce in a pint of boiling water is a tablespoonful every two to three hours.

Preparations-Fluid extract: Dose, I-2 drops. Glucoside, Adonidin : Dose, $\frac{1}{12}-\frac{1}{\frac{1}{2}}$ grain.

Distinctive character-Stem about 6-9 inches long alternate, terminated by a single large yellow flower, about I $\frac{7}{2}$ inch across, followed by an oval head of achenes 
about $\mathrm{I}$ inch long. Leaves alternate, finely divided in a pinnate manner into linear segments, sheathing at the base, the whole plant not hairy. Taste, slight. Odour, none.

\section{HEMLOCK.}

Conium maculatum, Linn. N.O. Umbellifera.

Syn.-Poison Hemlock, Poison Parsley, Conium, Spotted Hemlock.

Parts used-Leaves, seeds.

Action-Sedative, anodyne. Is of particular service in all spasmodic affections, such as chorea, epilepsy, acute mania, \&c. Also used with advantage in whooping cough. Should be administered with care as overdoses produce paralysis.

Preparations-Powdered leaves: Dose, I-3 grains. Fluid extract, leaves: Dose, 5-Io drops. Fluid extract, seeds: Dose, $2-5$ drops. Tincture, seeds, B.P.: Dose, $\frac{1}{3}$-I drachm. Juice of leaves B.P.: Dose, I-2 drachms. Solid extract: Dose, 2-6 grains. Ointment B.P.

Distinctive character-Leaves hairless, repeatedly pinnate, a foot long or more, angular in outline, the stem hollow, spotted, as well as the large leafstalks, with purplish spots; the tips of the leaflets end in a white point. Taste, unpleasant. Odour, disagreeable, mousey when the leaves are rubbed with Liquor Potassæ. The fruits are ovate, plano-convex, indented on the flat surface, with five crenate ridges on the back. Odour, none, unless rubbed with alkali, then mousey like the leaves.

\section{HEMP AGRIMONY.}

Eupatorium cannabinum, Linn. N.O. Composite.

Part used-Herb.

Action-Antiscorbutic, cathartic, diuretic. A good remedy for impurity of the blood. May be used by 
itself or combined with other herbs. The infusion of I ounce to a pint of water is taken in wineglassful doses four or five times a day.

Preparation-Fluid extract: Dose, $\frac{1}{2}-\mathrm{I}$ drachm.

Distinctive character-Stem angular, striated, rough. Leaves opposite, downy, three to five-lobed, the segments elongate-lanceolate, irregularly serrate, the central one longest. Flower-heads slender, five to sixflowered, florets all tubular, pinkish. Receptacle not hairy, pappus pilose. Taste, sweetish then bitter. Odour, faintly aromatic.

HENBANE.

Syn.-Hogbean.

Part used-Leaves.

Action-Anodyne, narcotic, mydriatic. Principally employed in irritable conditions and nervous affections. Also used in asthma, whooping cough, \&c., as a sedative and as a substitute for Opium, where this is inadmissible, as in children's complaints.

Preparations-Powdered leaves: Dose, 2-Io grains. Fluid extract: Dose, 2-10 drops. Tincture B.P. and U.S.P.: Dose, 1-I drachm. Solid extract: Dose, 2-8 grains. Juice B.P.: Dose, $\frac{1}{2}-\mathrm{I}$ drachm. Hyoscyamin : Dose, $\frac{1}{8}-1$ grain.

Distinctive character-Stem stout and as well as the leaves covered with long, soft, viscid hairs. Stem leaves oblong-ovate, sessile, clasping at the base, sinuate or almost pinnatifid. The rapbides in the leaves are minute single rhombic crystals of calcium oxalate. The flowers when present are cup-shaped, yellowish with purple veins, on a one-sided spike with leafy bracts. The capsular fruit opens transversely. Taste, slightly acrid. Odour, unpleasant, characteristic. 
HENNA.

Syn.- Henne, Alhenna.

\section{Part used-Leaves.}

Action-Astringent. The Indian natives ascribe wonderful properties to this plant, and use it in headache, smallpox, leprosy, \&c. Its greatest use is as a dye for the nails of the hands and feet, and in Europe for the hair.

Distinctive character-Leaves opposite, shortly stalked, smooth, lanceolate, mucronate, entire at the revolute margins, about I inch long, I inch wide, lateral veins incurved at their apex. Taste, slightly astringent. Odour, tea-like.

A section of the leaf shows a double row of palisade cells and numerous cluster crystals of Calcium Oxalate.

\section{HOLLY.}

Ilex Aquifolium, Linn. N.O. Aquifoliacea.

Syn.-Holm, Hulm, Hulver Bush.

Parts used-Leaves, berries.

Action-Febrifuge, cathartic. The leaves have been used in fevers and rheumatism, the berries in dropsy.

Distinctive character-The leaves are about 2 inches long and $1 \frac{1}{1}$ inch broad, oblong-ovate, shiny, leathery, with a spiny margin, but some leaves are almost free from spines. Taste and odour, none.

HOLLYHOCK.

Althaea rosea, Linn.

N.O. Malvacea.

Syn.-Common Hollyhock, Garden Hollyhock.

Part used-Flowers.

Action-Emollient, demulcent, diuretic. Useful in chest complaints; its action is similar to Marsh- 
mallow. The violet flowers are also used for colouring purposes.

Distinctive character-The dried flowers are deep purplish black about $2 \frac{1}{2}$ inches in diameter, united with the stamens, which form a tube, the one-celled reniform anthers remaining free. The corolla, freed from the calyx, is usually sold.

HOLY THISTLE.

Syn.-Cnicus benedictus, Carduus benedictus, Steud.

Part used-Herb.

Action-Tonic, diaphoretic, emmenagogue. In dyspepsia, intermittent fevers, and loss of appetite it is found very useful. The warm infusion-r ounce to a pint of boiling water-in doses of a wineglassful will be found of value in breaking up colds; it acts also well in menstrual derangements due to colds, \&c.

Preparation-Fluid extract: Dose, $\frac{1}{2}-\mathrm{I}$ drachm.

Distinctive character-Leaves greyish green, thin and brittle, with prominent pale veinlets, clasping the stem, the margins irregularly toothed, each tooth ending in a spine. Flowerheads about $I$ inch long and $I$ inch broad. Fruits cylindrical, $\frac{1}{2}$ inch long, finely ribbed longitudinally with an outer long and inner short row of stiff bristles within the toothed crown of the fruit. Involucral scales ovate, terminating in a long bristle. Taste, very bitter. Odour, none.

HONEYSUCKLE.

Lonicera Caprifolium, Linn. N.O. Caprifoliacea.

Syn.-Italian Honeysuckle, Meadow Trefoil, Pericly. menum.

Parts used-Flowers, leaves.

Action-Expectorant, laxative. The flowers, in the form of a syrup, have been used successfully in disorders 
of the respiratory organs and in asthma. A decoction of the leaves acts as a laxative and has been used with benefit in diseases of liver and spleen.

Distinctive character-The dried flowers are yellowish brown, mostly tubular flower-buds mixed with the stalked heads about $\frac{1}{4}$ inch in diameter of minute young fruits, from which the flowers have fallen. Leaves rather thin, $I_{\frac{1}{2}}-2$ inches long and $I-I \frac{1}{4}$ inch broad, oval-obtuse, shortly stalked, opposite, smooth, and with entire margins paler below. Taste, sweet, mucilaginous. Odour, imperceptible.

HOPS.

\section{Part used-Flowers (strobiles).}

Humulus Lupulus, Linn. N.O. Urticacea.

Action-Tonic, anodyne, diuretic. Generally used in combination with other remedies in debility, indigestion, worms, nervous conditions, \&c. A pillow filled with Hops is considered good for sleeplessness and nervous irritation. The infusion of $I$ ounce in a pint of boiling water may be taken in wineglassful doses as a good general tonic and sedative.

Preparations-Fluid extract: Dose, $\frac{1}{4}-\mathrm{I}$ drachm. Tincture B.P.: Dose, $\frac{1}{2}-2$ drachms. Lupulin: Dose, 5-10 grains. Infusion B.P.: Dose, $\frac{1}{2}-2$ ounces. Oleoresin U.S.P.: Dose, 3 grains. Solid extract, alc. : Dose, 5-Io grains.

Distinctive character-The leafy female catkin or strobile is about $\mathrm{I}-\mathrm{I} \frac{1}{2}$ inch long and $\frac{3}{\mathrm{~s}}-\mathrm{I}$ inch broad, and consists of membranous scales, which are yellowish green, oval about $\frac{1}{3}$ inch long, and reticulate-veined. The scales are of two kinds, the one equal and the other unequal at the base, the latter bearing a small seed-like fruit at the concave base, over which yellowish shining glands are scattered. Taste, bitter, aromatic. Odour, aromatic; in old catkins somewhat recalling valerian. The glands when separated by sifting are known as lupuline. 
HOREHOUND.

Syn.-Hoarhound.

Part used-Herb.

Action-Bitter tonic, expectorant, diuretic. Is perhaps the most popular of herbal pectoral remedies. It is exceedingly valuable in coughs, colds, and pulmonary affections. It has a pleasant taste and makes a nice tonic. In many parts it is brewed and sold as Horehound Ale, making an appetising and healthful beverage. Also a candy is prepared, and if properly made, is no doubt efficacious. An infusion of I ounce to a pint of boiling water is taken in wineglassful doses, frequently.

Preparations-Fluid extract: Dose, $\frac{1}{2}-\mathrm{I}$ drachm. Solid extract: Dose, 5-I5 grains. Syrup: Dose, 2.4 drachms.

Distinctive character-Stem and leaves coated with soft woolly hairs. Leaves cordate-ovate, shortly stalked, and crenate at the margins, reticulated on both sides. Flowers small, white, with axillary clusters. Calyx with ten veins, and ten teeth ending in rigid hooked points. Taste, bitter, aromatic. Odour, characteristic.

HOREHOUND, BLACK.

Ballota nigra, Linn.

Syn.-Marrubium nigrum, Crantz.

N.O. Labiate.

Part used-Herb.

Action-Stimulant, antispasmodic, vermifuge.

Distinctive character-Lower leaves cordate, upper leaves ovate, crenate, serrate, hairy. Flowers usually purplish, labiate. Calyx with five spreading broadly ovate teeth. Taste, unpleasant. Odour, disagreeable. 
HORSE CHESTNUT.

AEsculus Hippocastanum.

Syn.-Hippocastamum vulgave, Gaertn.

N.O. Sapindacea.

Parts used-Bark, fruit.

Action-Tonic, narcotic, febrifuge. The bark is used in intermittent fevers infused with boiling water -I ounce to a pint-and given in tablespoonful doses three to four times daily; this has also been used as an external application to ulcers. The fruits have been employed with success in treatment of rheumatic and neuralgic disorders ; also for rectal complaints, backache, piles, \&c.

Preparations-Fluid extract, fruit: Dose, 5-20 drops. Fluid extract, bark: Dose, $\frac{1}{2}-2$ drachms.

Distinctive character-The bark occurs in flattened pieces 4-5 inches long, and about $\mathrm{I}-\mathrm{I} \frac{1}{2}$ inch broad, and about I-I inch thick, greyish brown externally, with corky warts tangentially elongated; on the inner surface, pinkish brown, and finely striated longitudinally. Fracture finely fibrous and laminate towards the inner surface. Taste, bitter and astringent. Odour, none. The fruit is a capsule, splitiing into three valves, with short spines scattered on the surface, each containing a large brown polished seed, about I inch broad and $\frac{1}{2}$ inch thick, with a large dull, rough, and pale brown scar where it has been attached to the capsule. Seed white, giving a blue fluorescent infusion.

HORSEMINT.

Monarda punctata, Linn. N.O. Labiate.

Syn.-American Horsemint.

Parts used-Leaves, tops.

Action-Stimulant, carminative, diuretic. Like all the Mint family this drug may be serviceable as a stimulating diaphoretic in flatulence, nausea and vomiting. The warm infusion is a pleasant diuretic and it 
has also a reputation as an emmenagogue. The dose is a wineglassful several times daily.

Preparation-Oil (Oleum Monarde) U.S.P., I870: Dose, 2-Io drops.

Distinctive character-Leaves opposite, stalked, lanceolate, about 2 inches long, toothed, nearly smooth, flowers in axillary tufts, with sessile yellow and purple bracts, and a tubular five-toothed downy calyx. Corolla two-lipped yellow, with purple spots and two stamens. Taste, pungent, bitterish. Odour, recalling that of Thyme.

HORSEMINT, ENGLISH. Mentha sylvestris, Linn.

Part used-Herb.

N.O. Labiata.

Action-Carminative, stimulant.

Distinctive character-Leaves opposite, nearly sessile, ovate lanceolate, serrate, silky beneath, flowers labiate, arranged in axillary clusters crowded into linear spikes, bracts subulate. Taste and odour resembling that of garden mint (Mentha viridis, L.).

HORSENETTLE.

Solanum Carolinense, Linn.

N.O. Solanacea.

Syn.-Bullnettle, Sandbrier, Treadsoft, Treadsaf.

Parts used-Berries, root.

Action-Antispasmodic, sedative. This plant has lately come into prominence as a remedy in infantile and hysterical convulsions, but chiefly in epilepsy and paroxysms connected with menstrual derangements. The dose of the berries has been given as 5-60 grains, and of the root from 10 grains to 2 drachms.

Distinctive character-Root cylindrical, smooth, with a few slender rootlets, in pieces of $4-6$ inches long, 
with a thin pale brown bark easily abraded, showing white beneath, fracture tough, woody, with a radiate structure, with a few fine silky fibres projecting from the bark. Taste, bitter, then sweetish. Odour, none.

HORSERADISH.

\section{Part used-Root.}

Cochlearla Armoracia, Linn. N.O. Crucifera.

Action-Stimulant, diaphoretic, diuretic. An excellent stimulant to the digestive organs, and useful in the treatment of dropsy. A good condiment is made by steeping the scraped root in vinegar. Dr. Coffin recommends for dropsy an infusion prepared by pouring I pint of boiling water on I ounce of Horseradish and $\frac{1}{2}$ ounce of Mustard Seed (crushed). The dose is $2-3$ tablespoonfuls three times a day.

Preparations-Fluid extract: Dose, $\frac{1}{2}-\mathrm{I}$ drachm. Comp. Sp. Horseradish B.P.: Dose, I-2 drachms.

Distinctive character-Root white, cylindrical, about I foot long and about $\frac{3}{4}$ inch in diameter; usually sold fresh. Taste, pungent, mustard-like. Odour, when the root is scraped, recalling that of mustard, and irritating to the nostrils.

HORSETAIL.

Equisetum arvense, Linn.

N.O. Equisetaced.

Syn.-Scouringrush, Shavegrass, Marestail, Bottlebrush.

Part usod-Herb.

Action-Diuretic, astringent. It has been found beneficial in dropsy, gravel, and kidney affections. Also 
used in gonorrhœea and gleet with advantage. In urinary incontinence, the effect of cystic irritation, it is a very serviceable remedy. The ashes of this plant are very valuable in acidity of the stomach, dyspepsia, \&c., taken in doses of 3-10 grains.

Preparation-Fluid extract : Dose, $\frac{1}{2}=\mathrm{I}$ drachm.

Distinctive character-Stems branched, jointed, brittle, many angled 6-I9 without leaves but with sheaths at the joints, the teeth of which are long and acute and one ribbed at the top, the branches with rough sharp angles. Taste and odour, none. Joints about I inch long and $\frac{1}{4}-\frac{1}{16}$ inch in diameter.

HOUNDSTONGUE. Cynoglossum officinale, Linn. N.O. Boraginacee.

Syn.-Dogstongue.

Part used-Herb.

Action-Anodyne, demulcent, astringent. Has been employed in coughs, colds, catarrhs, diarrhca, and dysentery. Is very soothing to the digestive organs and relieves piles. Often used externally and internally at the same time.

HOUSELEEK.

Sempervivum tectorum, Linn.

N.O. Crassulacee.

Syn.-Common Houseleek, Sengreen, Joubarbe des toits (Fr.).

Part used-Fresh leaves.

Action-Refrigerant, astringent. The fresh leaves are bruised and applied as a poultice in inflammatory 
conditions of the skin such as burns, stings, \&c. It is positively said to cure warts and corns.

Distinctive character-Leaves forming rosettes 2-3 inches in diameter, fleshy, flat, sessile, oblongobovate, incurved, and pointed, hairy on the margin. Taste, saline, astringent, and acid. Odour, none.

HYDRANGEA.

Hydrangea arborescens, Linn.

N.O. Saxifragacea.

Syn.-Wild Hydrangea, Seven Barks.

\section{Part used-Root.}

Action-Cathartic, diuretic, nephritic. A valuable remedy for the removal of stone and gravel in bladder. Its greatest value is due to its power of preventing any gravelly deposits. The infusion of I ounce of root in a pint of boiling water may be taken in wineglassful doses, hot, if desired.

Preparation-Fluid extract : Dose, $\frac{1}{2}-2$ drachms.

Distinctive character-Root pale fawn-coloured, smooth with gradually tapering branches, hard and woody, bark very thin, the wood porous and radiate in structure, in the larger pieces, of apparently underground branches, there is a distinct white pith. Taste of the bark, slightly sweetish and pungent. Odour, none.

HYSSOP.

Part used-Herb.

Action-Stimulant, carminative, pectoral. This forms an agreeable remedy in cases of colds, coughs, consumption, and lung complaints. It is generally compounded 
with other remedies. The dose of the infusion, made from I ounce of herb in a pint of boiling water, is a wineglassful, taken frequently.

Preparation-Fluid extract: Dose, $\frac{1}{-1}$ drachm.

Distinctive character-Stem woody, leaves linearlanceolate, nearly sessile, about $\frac{1}{2}$ inch long and $\frac{1}{8}$ inch broad, hairy on the margin. Flowers in axillary tufts arranged on one side. Calyx of five unequal teeth. Stamens, four. Taste, bitter. Odour, aromatic and camphoraceous.

ICELAND MOSS.

Cetraria Islandica, Ach. N.O. Lichenes.

Syn.-Iceland Lichen, Cetraria.

Part used-Lichen.

Action-Demulcent, tonic, nutritive. Ordinary doses improve the appetite and digestion, and do not produce constipation, but excessive doses may induce looseness of bowels. Highly recommended in chronic catarrh, chronic bronchitis, and consumption, as it relieves the cough and assists the system by its nutritive properties. The decoction is generally made of the strength of I ounce to the pint, and the moss should be well washed before it is used.

\section{Preparation-Decoction B.P., I885: Dose, I-4 ounces.}

Distinctive character-Thallus smooth, grey or light olive brown, foliaceous, branching, about 2-4 inches high, curled, channelled or rolled into tubes, terminating in spreading flattened lobes with the edges fringed with small papillæ. The under surface is paler with depressed minute white spots. Taste, bitter. Inodorous, but when wetted its odour recalls that of seaweed. 
IGNATIUS BEANS.

Strychnos Ignatil, Berg.

N.O. Loganiacee.

Syn.-Saint Ignatius Beans, Ignatia amara, Linn. f.

Part used-Seeds.

Action-Stimulant, tonic. Its properties are similar to Nux Vomica, possibly more active, and it is used in functional nervous disorders, neuralgia, and debility, \&c. It also contains Brucine and Strychnine, poisonous alkaloids.

Distinctive character-Seeds ovoid, irregularly angular, about $I$ inch long and $I \frac{1}{2}$ inch in diameter, with a definite hilum at one end. Externally dull grey, granular, with occasionally fragments of brown epidermis still adhering to the surface. Internally hard, horny. Taste, intensely bitter. Odour, none.

INDIAN HEMP.

Cannabis sativa, Linn.

N.O. Urticacea.

Syn.-Cannabis Indica, Lamk., Guaza, Ganjah, Bhang, Dagga.

Part used-Tops.

Action-Anodyne, hypnotic, antispasmodic. Is principally used to allay spasmodic pains of nervous origin where there is a marked nervous depression. It produces sleep without derangement of the digestive organs and is therefore more suitable, in many cases, than Opium. Used for smoking by the Arabs and other Eastern tribes.

Preparations-Fluid extract: Dose, I-3 drops. Tincture B.P. and U.S.P.: Dose, 5-15 drops. Solid extract B.P.: Dose, $\frac{1}{4}-I$ grain.

Distinctive character-The herb is usually sold in the form of the dried tops of the female flowering plant, 
and may be recognised by the presence of hemp seeds, of which there are usually some present in a more or less immature state. The leaves are long-stalked, bearing usually five to seven lanceolate-acuminate leaflets, sharply serrate at the margin, arranged in a radiate manner; they are brittle, and usually more or less adherent, due to the exudation of resin. Taste, very slight. Odour, somewhat smoky, but characteristic.

INDIAN PHYSIC.

Gillenia trifoliata, Mœnch.

G. stipulacea, Pursh.

N.O. Rosacea.

Syn.-Spiraea trifoliata, Linn.; and S. stipulata, Muhl., Indian Hippo, Gillenia.

Part used-Rootbark.

Action-Expectorant, cathartic, emetic. The Ameri can Indians use the above-mentioned plants in the same way as Ipecacuanha. They recommend it in dyspepsia, dropsy, habitual constipation, coughs, colds, \&c. Being a safe and efficient emetic, it can be used with advantage where such may be indicated. A dose of the powder of 2 grains acts as a stomachic ; 5.6 grains produce diaphoresis, and 20-30 grains produce emesis and catharsis. The smaller doses may be repeated every three to four hours.

Distinctive character-The roots of both species are collected and sold under the name of Indian Physic. The roots are cylindrical, sometimes undulated, usually fissured transversely, and 6 inches or more long, varying from $\frac{1}{10}-\frac{1}{8}$ inch in diameter. They have a blackish hue externally, and the transverse section shows a thick reddish bark, with a short fracture, separating easily from the white woody centre. The bark is pleasantly bitter, the wood tasteless. Odour, none. 
IPECACUANHA, Psychotria Ipecacuanha, Stokes. N.O. Rubiacece.

Syn.-Cephaelis Ipecacuanha, Rich., Ipecac.

Part used-Root.

Action-Diaphoretic, emetic, expectorant. Small doses act effectually as an expectorant, and may be given for coughs, colds, dysentery, and to produce perspiration. Full doses produce free emesis. An infusion of I ounce to a pint of boiling water may be taken in teaspoonful to wineglassful doses as above directed. Mostly combined with other remedies.

Preparations-Powdered root: Dose, 5-30 grains. Fluid extract B.P.: Dose, 2-20 drops. Comp. Tincture (Dover's) U.S.P.: Dose, 8 drops. Wine B.P.: Dose, Io drops to 6 drachms. Syrup U.S.P.: Dose, $\frac{1}{1}-4$. Dover's powder B.P.: Dose, 5-I 5 grains.

Distinctive character-The root is brownish or blackish externally, cylindrical, tortuous and strongly annulated. The fracture is short. The bark is hard, greyish internally, horny, surrounding a yellowish white woody centre, which is radiate but not porous. Taste, acrid, bitterish, and disagreeable. Odour, strong and unpleasant.

IRISH MOSS.

Chondrus crispus, Stackh. N.O. Alga.

Syn.-Chondrus, Carragheen, Carrageen, Caragahen.

Part used-Plant.

Action-Demulcent, pectoral, nutritious. Used in chronic coughs, bronchitis, pneumonia, \&c. Also in irritating diseases of the bladder and kidneys, and as a culinary article. The decoction is made as follows: Steep $\frac{1}{2}$ ounce of Irish Moss in cold water for Io minutes, then boil in 3 pints of water or milk for a quarter of an hour, strain through linen, and season with liquorice, sugar, 
lemon juice, cinnamon, nutmeg, or other flavours to taste.

Distinctive character-This dried seaweed, erroneously called moss, has a flat forked frond varying in width from $\frac{1}{8}-\frac{1}{2}$ inch and about $\frac{1}{18}-\frac{1}{12}$ inch thick. It varies in length from $2 \frac{1}{2}-5$ inches, and has a fan-shaped outline. The fronds of Gigartina mammillosa, J. Ag., which have a similar shape, are usually incurved at the margins of the stem, and have papillæ on the ultimate segments, but possess similar properties. Taste, mucilaginous and saline. Odour, that of seaweed.

\section{ISPAGHUL.}

Plantago ovata, Forsk. N.O. Plantaginacece.

Syn.-Plantago Ispaghula, Roxb.; Plantago decumbens, Forsk; Spogel, Spogul.

Part used-Seeds.

Action-Demulcent, astringent. Useful in dysentery, diarrhœa, and affections of kidneys and bladder. Dose 2 drachms of the seeds mixed with sugar and swallowed dry.

Distinctive character-The seeds are greyish, boatshaped, with the hollow side exhibiting a brown centre. About $\frac{1}{12}$ inch long, and barely $\frac{1}{24}$ inch broad, the margins are incurved on the hollow side. Taste, mucilaginous. Odour, none.

IVY.

Syn.-Common Ivy.

Parts used-Leaves, berries.

Action-Stimulating, diaphoretic, cathartic. Externally the leaves have been employed as poultices or fomentations in glandular enlargements, indolent ulcers, abscesses, \&c. The berries are found of use in febrile disorders, and a vinegar of these was extensively used during the London plague.

Distinctive character-Leaves dark green, paler beneath, leathery, shining, long-stalked, about 2-4 inches 
wide, and long, radiate-veined, with three to four triangular lobes; the upper leaves ovate or oval-lanceolate. The berries are about the size of a pea, purplish black, with a disk at the apex corresponding to the calyx rim. Seeds two or three ruminated. Taste, bitter and nauseous. Odour, when rubbed, aromatic and slightly resinous.

IVY, AMERICAN.

Vitis hederacea, Willd. N.O. Vitacea.

Syn.-Ampelopsis quinquefolia, Mich., Cissus hederacea, Ross., Cissus quinquefolia, Desf., Virginian Creeper, Vitis quinquefolia, Lam., Woodvine.

Parts used-Bark, twigs.

Action-Tonic, expectorant, astringent. This drug is principally used in scrofulous and syphilitic affections, in the form of a syrup. In dropsy, bronchitis, and in pulmonary complaints it may be recommended. The decoction of I ounce in a pint of boiling water is taken in wineglassful doses.

Preparations-Fluid extract: Dose, $\frac{1}{2}-\mathrm{I}$ drachm. Ampelopsin: Dose, 2-4 grains.

Distinctive character-The bark occurs in quilled pieces $2-3$ inches long and from $\frac{1}{1}-\frac{1}{2}$ inch in diameter, externally brown, with enlarged transverse scars formed from lenticels. The fracture shows a white bark with coarse flattened fibres in the inner portion. Taste, insipid. Odour, faintly aromatic. The leaves are stalked, digitate, with five oblong lanceolate leaflets.

JABORANDI.

Part used-Leaves.

Action-Stimulant, diaphoretic, expectorant. Specially useful in asthma and diabetes. A teaspoonful of 
powdered leaves infused in a cupful of boiling water and taken as a dose will cause free perspiration and salivation. Generally the infusion of I ounce of leaves in a pint of boiling water is taken in wineglassful doses or less as required.

Preparations-Powdered leaves: Dose, 5-60 grains. Fluid extract B.P.: Dose, I0-30 drops. Tincture B.P. : Dose, $\frac{1}{2}-I$ drachm. (Alkaloid) Pilocarpine: Dose, $\frac{1}{20}-\frac{1}{2}$ grain.

Distinctive character-The leaflets (five to one leaf) are usually detached, brownish green, oblong, slightly unequal at the base and emarginate at the apex, $2 \frac{1}{2}-5$ inches long, and about $\frac{8}{4}-1 \frac{1}{2}$ inch broad, margin entire and slightly recurved, veins prominent on the upper surface; furnished with numerous translucent oil cells. Taste, pea-like. Odour, slight.

The official Jaborandi is now replaced in commerce by the leaves of Pilocarpus microphyllus, Stapf., which are dull green and much smaller, being only $\frac{1}{2}-I_{2} \frac{1}{2}$ inch long and $\frac{1}{3}-\frac{2}{3}$ inch broad, but otherwise similar in taste and character.

The leaves of Pilocarpus pinnatifolius, Lemaire, which have also appeared in commerce, are about the size of those of $P$. Jaborandi, Holmes, but they are greyish green, the veins are not prominent on the upper surface, and the leaves are only half as active.

JACOB'S-LADDER. Polemonium coeruleum, Linn. N.O. Polemoniacea.

Syn.-Greek Valerian, English Greek Valerian.

Part used-Plant.

Action-Diaphoretic, astringent. For medicinal uses see Abscess Root.

Distinctive character-The leaves are 5-6 inches long, imparipinnate, with about I7 lanceolate leaflets 
about I inch long and $\frac{1}{3}$ inch broad, which are alternate except towards the apex of the leaf, and entire at the margins; the rachis is channelled above. Flowers rotate, blue, and five-parted. Taste, slightly bitter. Odour, none.

\section{JALAP.}

Ipomaea Purga, Hayne. N.O. Convolvulacee.

Syn.-Ipomea Jalapa, Schiede and Deppe, Convolvulus Jalapa, Linn., Exogonium Purga, Benth., Convolvulus Purga, Wender.

Parts used-Root, resin.

Action-Cathartic, purgative. Used in constipation, pain and colic in bowels, and general intestinal torpor. Is combined with other laxatives and with carminatives such as ginger, cloves, \&c.

Preparations-Powdered root: Dose, 5-20 grains. Tincture B.P.: Dose, $\frac{1}{2}-\mathrm{I}$ drachm. Powdered resin: Dose, 2-5 grains. Compound Powder B.P.: Dose, I-2 drachms. Tincture B.P.: Dose, $\frac{1}{2}-1$ drachm. Solid extract B.P.: Dose, 2.8 grains. Jalapin: Dose, I-3 grains.

Distinctive character-Root usually ovoid, varying greatly in size, but on the average $2 \frac{1}{2}$ inches long by $\mathrm{I}_{\frac{1}{2}}$ inch in diameter, dark brown, wrinkled, with paler, small transverse marks, often more numerous at one end. The interior is dirty white, tough, hard, and sometimes horny, with a resinous non-fibrous fracture. Taste, unpleasant, followed by acridity. Odour, smoky.

JAMAICA DOGWOOD.

Part used-Bark.

Actiun-Anodyne, sedative. Relieves toothache, eases bronchial and consumptive cough. Produces 
sleep and allays pain and nervous excitement. Unpleasant results have occurred by overdoses. Generally combined with Black Haw and other remedies in female complaints, \&c.

Preparations-Fluid extract: Dose, 5-20 drops, which may be gradually increased to 2 drachms. Solid extract: Dose, I-5 grains.

Distinctive character-The bark occurs in quilled, curved pieces about $2-6$ inches long and $\frac{1}{8}-\frac{1}{4}$ inch thick, dark grey-brown externally, with thin, longitudinal and transverse ridges, roughish and wrinkled, and somewhat fissured. Fracture tough, fibrous, with blue-green or brownish green patches. Taste, bitter and somewhat acrid. Odour, opium-like.

JAMBUL.

Eugenia Jambolana, Lamk. N.O. Myrtacea.

Syn.-Jamboo, Java-Plum, Jambool.

\section{Part used-Seeds.}

Action-Astringent, diuretic. This drug has been found very useful in diabetes, as it reduces the amount of sugar present in urine in a very brief space of time. Although not a specific in all cases of diabetes, it promises to be of the greatest value and should be tried whenever an occasion presents itself.

Van Noorden recommends large doses in cases of diabetes mellitus, and says $\frac{1}{2}$ ounce of the fluid extract in 8 ounces of hot water should be taken one hour before breakfast and last thing at night.

Preparations-Powdered seeds : Dose, 5-30 grains. May be administered in cachets or capsules. Fluid extract: Dose, I-2 drachms.

Distinctive character-The seeds as met with in commerce are muller-shaped, blackish brown, about 
t inch long and rather less in diameter, one end truncated with a central depression, hard and tough externally, and internally pinkish brown, with glistening starch grains. Taste, faintly astringent and slightly aromatic. Odour, none.

\section{JEQUIRITY.}

Abrus precatorius, Linn.

N.O. Leguminosa.

Syn.-Indian Liquorice, Wild Liquorice.

Part used-Seeds.

Action-Irritant. It may be very cautiously used in eye diseases, and not until other means have been exhausted, as it produces a violent conjunctival inflam. mation and is likely to destroy the corneal structures.

Distinctive character-Seeds oval, rounded at the ends, about $\frac{1}{8}$ inch in diameter, hard and polished, vermilion red, with the upper third black; very hard and tough.

JEWEL WEED.

Impatiens aurea, Muhl., and I. biflora, Walt. N.O. Geraniacea.

Syn. $-I$. aurea, Muhl. $=I$. pallida, Nutt., Pale Touchme-not, Balsam Weed. I. biflova, Walt. =I. fulva, Nutt., Spotted Touch-me-not, Jewel Weed, Speckled Jewels.

Part used--Herb.

Action-Aperient, diuretic. The fresh plants boiled with lard form an excellent application for piles. The juice is reputed to remove warts, corns, and cure ringworm. In jaundice and dropsy the decoction has been found valuable in doses of a wineglassful repeated three to four times a day.

Distinctive character-Stems jointed, leaves greygreen, thin, ovate-oval, more or less toothed. Flowers 
axillary, solitary, slipper-shaped with a long recurved spur: in I. pallida, Nutt., pale yellow, and in $I$. fulva, Nutt., orange-yellow and spotted. Valves of the fruit curling up when dehisced.

JOHNS BREAD.

Ceratonia sillqua, Linn.

N.O. Leguninosa.

Syn.-St. John's bread.

Part used-Pods.

Action-Nutritive. Used as a food for man and beast, and by singers to improve the voice.

Distinctive character-The pods are 4-8 inches long and about $\mathrm{I}$ inch broad and $\frac{1}{8}$ or $\frac{1}{8}$ inch thick, compressed, dark brown, glossy, enclosing a light brown, soft, fleshy pulp having a sweet taste. Seeds flattish, ovate, in separate cells, lined with the papery endocarp. Odour, slightly valerianic.

JUJUBE BERRIES. Zizyphus vulgaris, Lamk. N.O. Rhamnacee.

\section{Part used-Berries.}

Action-Mucilaginous, pectoral. From these the genuine "Pâte de Jujubes" was formerly prepared for use in the manufacture of pectoral lozenges.

Distinctive character-Fruits variable in size in different varieties, from $\frac{1}{2}-\mathrm{I}$ inch long and $\frac{8}{8}-\frac{1}{2}$ inch in diameter, red, smooth, and shiny, but brownish red and wrinkled when dried, fleshy and containing one or two endocarps. Taste, sweet and mucilaginous. 


\section{JUNIPER BERRIES. Juniperus communis, Linn. \\ Part used-Berries. \\ N.O. Conifera.}

Action-Diuretic, stimulant, carminative. As a rule these are given in conjunction with other remedies for kidney complaints. The oil extracted from berries and wood is also largely used. The infusion of I ounce of berries to a pint of boiling water is taken in wineglassful doses.

Preparations-Fluid extract: Dose, $\frac{1}{2}-\mathrm{I}$ drachm. Oil of berries B.P.: Dose, I-5 drops. Oil of wood: Dose, I-5 drops. Spirit B.P., U.S.P.: Dose, 20-60 drops. Comp. Sp. U.S.P.: Dose, 2 drachms. Solid extract alc. : Dose, 5-I 5 grains.

Distinctive character-Berry (fleshy galbulus) $\frac{3}{10} \cdot \frac{4}{10}$ inch in diameter, globular. Purplish black with a bluegrey bloom when recently collected, and a triangular line at the apex, indicating the junction of the three fleshy bracts forming the fruit, which contains three seeds. Taste, aromatic and turpentiny. Odour, turpentiny, but characteristic.

JURUBEBA.

Parts used-Root, fruit.

Solanum insidiosum, Mart. N.O. Solanacea.

Action-Tonic, alterative, cathartic. Brazilians use it with success in liver and spleen disorders, also in anæmia and amenorrhœa. It is reputed as an excellent remedy in habitual constipation. The dose of the powdered root is from 5-30 grains.

This root is generally referred to Solanum paniculatum, Linn., but Kobert has shown that the root of this species is inert. D. T. Pecholt states that the true root is obtained from L. insidiosum, Mart. Possibly the former is called Jerubeba, this form of spelling being sometimes used. 
Syn.-Rottlera tinctoria, Roxb., Kameela, Spoonwood.

Part used-Capsule glands.

Action-Tænifuge, purgative. Has long been used in India with success. The doses of powder vary from 2-3 drachms for adults, repeated if necessary. The worm is usually expelled entire. The fluid extract acts milder and with more certainty.

Preparations-Powdered Kamala: Dose, 2-4 drachms. Fluid extract: Dose, 2-4 drachms.

Distinctive character-The red glands covering the fruit, obtained by sifting the fruit, form a red mobile powder, which floats in water. The grains, after treatment with alcohol or potash solution, to dissolve out the colouring matter, show a radiate structure. The powder often contains a quantity of sand, which can be removed by stirring the Kamala in water, when the latter floats, and can be separated. Tasteless and nearly odourless, but an alcoholic solution poured into water gives off a melon-like odour.

KAVA-KAVA.

Piper methysticum, Forst. N.O. Piperacee.

Syn.-Ava, Ava pepper, Kava.

Part used-Root.

Action-Tonic, stimulant, diuretic. Has been employed in bronchitis, rheumatism, and gout, and is recommended in gonorrhœa and gleet, augmenting the discharges before a cure, which is effected in the short 
time of 10.12 days. Is also a remedy for nocturnal incontinence of urine, due to muscular weakness.

Preparations-Root: Dose, I drachm. Fluid extract: Dose, $\frac{1}{2}$-I drachm. Solid extract alc. : Dose, 5-I 5 grains.

Distinctive character-Root large, and usually cut into segments 2 inches or more in diameter, externally blackish grey, internally whitish, fracture mealy and somewhat splintery, central portion porous, with irregularly twisted thin wood bundles separated by broad medullary rays, so that under the thick bark the wood bundles form distinct meshes. Rootlets, when not removed, often $\mathrm{I} 2$ inches long or more, and more or less fibrous. Taste, somewhat pungent and numbing. Odour, agreeable, lilac-like.

KINO.

Pterocarpus Marsupium, Roxb. N.O. Leguminosa.

Syn.-Gum Kino.

Part used-Inspissated juice.

Action-Astringent. It is considered valuable in diarrhœa and dysentery. Used as an application in leucorrhœa, relaxed throat, \&c.

Preparations-Powdered gum: Dose, 5-20 grains. Comp. powder B.P.: Dose, $5 \cdot 20$ grains. Tincture B.P. and U.S.P.: Dose, $\frac{1}{2}-\mathrm{I}$ drachm.

Distinctive character-In small, blackish, shining fragments, or in coarse powder. Taste, very astringent. It adheres to the teeth when chewed. If properly prepared by boiling the juice as collected, it is entirely soluble when the powder is shaken up with cold water; the solution gives a violet colour with a protosalt of iron. 
KNAPWEED.

Centaurea nigra, Linn.

Syn.-Star Thistle.

N.O. Composita.

Parts used-Root, seeds.

Action-Diuretic, diaphoretic, tonic.

Distinctive character-Readily recognised by the globular flower heads, about 2 inches long and $\mathrm{I} \frac{3}{4}$ inch broad, the outer scales of which have blackish appendages at the apex with comb-like teeth. Florets purplish, tubular. Fruit without pappus, but surrounded with bristles (paleæ). Taste, bitter, slightly saline. Odour, none.

KNOTGRASS, RUSSIAN.

Polygonum erectum, Linn.

Part used-Herb.

N.O. Polygonacea.

Action-Astringent. The infusion has been found highly beneficial in diarrhœa and children's summer complaints.

Distinctive character-Stem slender, cylindrical, striated. Leaves narrowly lanceolate, about $\frac{1}{2}$ inch long and $\frac{1}{16}-\frac{1}{8}$ inch broad, sheathing stipules (ochrea) lanceolate. Seed (nut) triangular, striated, with raised points. Taste, astringent. Odour, none.

English Knotgrass is Polygomum aviculare, Linn., and has similar properties to the Russian variety.

KOLA.

Cola vera, Schum. (and other species).

N.O. Sterculiacea.

Syn.-Sterculia acuminata, Beauv., Kola Nut, Guru Nut, Cola.

Action-Nerve stimulant, diuretic, cardiac tonic. A good general tonic, depending largely for its influence 
upon the Caffeine it contains. Used by the African natives to enable them to perform arduous tasks without the aid of food. It is an excellent remedy for diarrhœa, and is also prescribed for the alcohol habit.

Preparations-Fluid extract: Dose, 10-40 drops. Solid extract alc. : Dose, $2-8$ grains.

Distinctive character-The fleshy, dried cotyledons are the form in which the seed is met with in commerce. They are brown, often irregular in shape, usually oblong, convex on one side and flattened on the other, $1 \frac{1}{2}-2$ inches long, and about I inch in diameter. Taste, astringent and somewhat earthy. Odour, very slight.

KOUSSO.

Hagenia abyssinica, Willd. N.O. Rosacea.

Syn.-Kooso, Kusso, Kosso, Cossoo, Cusso, Brayera anthelmintica, Kunth.

\section{Part used-Herb.}

Action-Purgative, tænifuge, anthelmintic. Used successfully for tapeworms. The infusion of $\frac{1}{2}$ ounce in a pint of boiling water is taken in teacupful doses, quickly following each other. Preparation by Castor Oil or other purgative is necessary, the Kousso to be taken on an empty stomach. A gentle cathartic after its operation is also advisable.

Preparation-Fluid extract: Dose, 2-4 drachms.

Distinctive character-The inflorescence is usually in the form of a cylindrical roll about 12 inches long and $2 \frac{1}{2}$ inches in diameter, consisting usually of the female inflorescence. The flowers are nearly $\frac{1}{2}$ inch across, the ten sepals in two rows are veined and leaflike, and the petals minute and linear. Stamens II-25, but in the female flower the anthers are sterile. 
LABRADOR TEA.

Syn.-James's Tea.

Part used-Leaves.

Action-Pectoral, expectorant, diuretic. Is very useful in coughs, colds, bronchial and pulmonary affections. For internal use the infusion is taken in wineglassful doses. A strong decoction has been recommended for external use as a remedy for-itching and exanthematous skin diseases.

Distinctive character-Leaves linear-lanceolate, alternate, almost sessile, $\mathrm{r}-2$ inches long and $\frac{1}{4}$ inch broad; the upper surface dark green and smooth, the under surface coated with rusty brown simple hairs, and multi-cellular short-stalked glands; the margin is revolute. Taste, bitter and camphoraceous. Odour, aromatic.

LACHNANTHES.

Lachnanthes tinctoria, Ell. N.O. Hamodoracea.

Syn.-Spirit weed, Red or Paint root, Wool Flower.

Parts used-Root, herb.

Action-Stimulating, hypnotic. Has been recommended in cough, consumption, pneumonia, \&c. Large doses produce unpleasant symptoms.

Preparation-Fluid extract: Dose, r-5 drops.

Distinctive character-Rhizome about I inch long, surrounded with long, slender, deep-red roots. Leaves falcate, in a basal rosette $\frac{1}{5}-\frac{3}{5}$ inch wide, sheathing at the base and, as well as the stems, reddish brown when dried, and reduced in size on the stem to small bracts. Flowers six, parted, with three stamens in a close woolly cyme. Taste, somewhat acrid. Odour, none. 


\section{LADIES' BEDSTRAW.}

Galium verum, Linn. N.O. Rubiacea.

Syn.-Yellow Bedstraw, Maid's hair, Cheese rennet, Wild Rosemary.

Part used-Herb.

Action-Diuretic, alterative. This is a popular remedy in gravel, stone, and urinary diseases, and has been used in hysterical complaints and epilepsy. The infusion is made with I ounce of herb in a pint of boiling water and taken in wineglassful doses several times a day.

Distinctive character-Stems slender, angular. Leaves linear, with revolute margins, downy beneath, about eight in a whorl. Flowers in terminal panicles, golden yellow. Taste, astringent, bitterish, and slightly acid. Odour, none.

LADIES' MANTLE.

Syn.-Lion's Foot.

Part used-Herb.

Action-Astringent, styptic. Used as a cure for excessive menstruation and flooding. Taken internally as an infusion of I ounce to a pint of boiling water in teacupful doses as required. Also employed as an injection.

Preparation-Fluid extract: Dose, $\frac{1}{2}-\mathrm{I}$ drachm.

Distinctive character-Leaves rounded, about 2 inches in diameter, having nine obtuse, serrate lobes, and slender stalks about 4 inches long, the whole plant furnished with soft silky hairs. Flowers green, in small clusters, borne on a forked stem which has small threelobed leaves and broad stipules at the base of each fork. The flowers have no petals and only one to four stamens. Taste, slightly astringent. Inodorous. 


\section{LADIES' SLIPPER.}

Cypripedium pubescens, Willd. N.O. Orchidacea.

Syn.-Cypripediun hirsutum, Mill., American Valerian, Nerveroot, Noah's ark, Yellow Ladies' Slipper.

Part used-Root.

Action-Antispasmodic, nervine, tonic. It allays pain, gives sleep, and is useful in headache, neuralgia, and female weaknesses. For this reason it is given in hysteria and most nervous disorders. Prescribed with tonic medicines its power is increased. The powder may be taken in sweetened water.

Preparations-Powdered root: Dose, I drachm. Fluid extract: Dose, $\frac{1}{2}-\mathrm{I}$ drachm. Cypripedin: Dose, I-3 grains. Solid extract, alc. : Dose : 5-Io grains.

Distinctive character-Rhizome 2.4 inches long, and $\frac{1}{8}-\frac{1}{4}$ inch thick, with numerous cup-shaped scars on the upper surface, and many unbranched, wavy, denselymatted roots below. Fracture short, white. Odour, slightly valerianic. Taste, sweetish, acrid, bitter, and aromatic. The drug of commerce is derived from both Cypripedium pubescens, Willd., and C. parviflorum, Salisb.

\section{LARCH.}

Larix Europæa, D.C.

N.O. Conifera.

Syn.-Pinus Larix, Linn., European Larch.

Part used-Bark.

Action-Astringent, balsamic, diuretic. A strong tincture has been used in chronic urinary inflammations, also in bronchitis to check secretions.

Preparation-Venice turpentine.

Distinctive character-The inner bark of the tree, deprived of its grey, inert, outer portion, is preferred for 
medicinal use. It occurs in flattish pieces, externally red-brown, with a rosy tint internally, the inner surface smooth, and pinkish brown or yellowish. Fracture short, slightly fibrous. Odour, terebinthinous. Taste, astringent, turpentiny, somewhat bitter.

\section{LARKSPUR.}

Delphinium Consolida, Linn. N.O. Ranunculacea.

Syn.-Lark's Claw, Lark's Heel, Knight's Spur.

Part used-Seeds.

Action-A tincture of the seeds acts as a parasiticide and insecticide, and is used to destroy lice and nits in the hair. Used also in spasmodic asthma and dropsy, the tincture (I ounce to I pint dilute alcohol) is given in ro.drop doses, gradually increased.

Distinctive character-Seeds black, tetrahedral, flattened, $\frac{1}{24}-\frac{1}{16}$ inch in diameter, with acute edges and pitted surface. Albumen oily. Taste, bitter and acrid. Inodorous.

\section{LAUREL.}

Laurus nobllis, Linn. N.O. Lauracea.

Syn.-Bay, Sweet Bay, Noble Laurel, Roman Laurel.

Parts used-Leaves, fruit, oil.

Action-Stomachic. The ancients valued Laurel greatly, but nowadays hardly any other preparation is used in medicine but the oil, as an application in rheumatism, \&c.

Distinctive character-The leaves are leathery, dark green, rather paler beneath, about 3 inches long and $\mathrm{I}$ inch broad, elliptic-lanceolate, slightly broader above the middle, entire, but wavy at the margins, the small whitish veins forming a network of nearly square minute meshes. Taste, aromatic. Odour, aromatic when bruised. 
Syn. - Lavandula officinalis, Chaix.

N.O. Labiata.

Part used-Flowers.

Action-Stimulant, carminative. Seldom used in medicine. The infusion is made from I drachm of flowers to a pint of boiling water.

Preparations-Fluid extract: Dose, $\frac{1}{2}-\mathrm{I}$ drachm. Compound tincture B.P. and U.S.P. : Dose, $\frac{1}{2}$-I drachm. Oil: Dose, I-3 drops. Spirit B.P. and U.S.P.: Dose, 5-30 drops.

Distinctive character-The flowers are usually met with in commerce separated from the flower spikes. The calyx is tubular, purplish grey, and five-toothed,

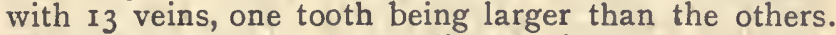
The tubular corolla is two-lipped, the upper lip with two and the lower with three lobes. The whole of the flowers have a dense covering of stellate hairs, with minute shining oil-glands, visible under a lens. Taste, pleasant. Odour, fragrant and characteristic.

\section{LAVENDER COTTON.}

\section{Santolina Chamœeyparissias, Linn.}

Part used-Herb. N.O. Composita.

Action-Used as an emmenagogue and a remedy for worms in children.

Preparation-Infusion (I ounce to I pint): Dose, a wineglassful frequently.

Distinctive character-Stem white, with cottony hairs. Leaves linear, about I-2 inches long and $\frac{1}{4}$ inch wide, with short, linear-oblong, obtuse teeth arranged in four rows. The flowerheads are sub-globular, borne on long leafless flowerstalks, yellow, with the outer bracts lanceolate and pointed, and the inner, obtuse and membranous at the tips. The fruits have no pappus. The taste is bitter. Odour, strong and aromatic, recalling that of chamomile. 
LEMON.

Citrus Limonum, Risso.

N.O. Rutacea.

Syn.-Limon, Citrus Medica, Var $\beta$ Limonum, Hook.

Parts used-Fruit, rind, juice.

Action-Tonic, refrigerant, antiscorbutic. The juice may be freely used as such, or in syrup form as a refreshing drink in all febrile diseases. It is a popular remedy in coughs and colds. The rind is mostly employed for flavouring purposes both in household and in medicine. The juice of a lemon served with hot water and sugar is a well-known French remedy for colds.

Preparations-Succus Limonis B.P.: Dose, $\frac{1}{2}-4$ drachms. Syrup Lemon B.P.: Dose, $\frac{1}{2}-4$ drachms. Tincture Lemon B.P. and U.S.P. : Dose, $\frac{1}{2}-1$ drachm.

Distinctive character-This well-known fruit occurs in several varieties, which differ in thickness of rind, and consequent percentage of juice. Those with moderately thin peel, and of medium size, about $2 \frac{1}{2}-3$ inches long and 2 inches in diameter, are the best, and the Messina lemons have the finest flavour. Coarser lemons from Malaga arrive in September and October. These have thick skins and numerous seeds, and less juice. A medium-sized lemon yields about two ounces of juice containing 40.46 grains of citric acid per ounce, or about $9 \frac{1}{2}$ per cent.

\section{LETTUCE, WILD.}

Syn.-Lettuce-Opium.

Parts used-Concrete juice (Lactucarium), leaves.

Action-Anodyne, sedative, expectorant. Is frequently used in the form of a syrup to allay irritable coughs when a soothing agent is wanted. Also used as an anodyne and hypnotic when Opium cannot be given.

Preparations-Lactucarium: Dose, 5-20 grains. Fluid extract, leaves: Dose, f-r drachm. Syrup 
U.S.P.: Dose, 2 drachms. Tincture U.S.P.: Dose, 30 drops. Solid extract: Dose, I-Io grains.

Distinctive character-Lettuce opium, or Lactucarium, is usually in angular fragments or quarters, curved on one side, indicating removal from a cup or saucer in which the milky juice has been collected and dried. Externally it is dark reddish brown, internally opaque and wax-like. Odour, resembling opium. Taste, very bitter. Scotch Lactucarium, which occurs in irregular small fragments, is now rarely seen.

LIFE EVERLASTING. Antennaria dioica, Gaertn. N.O. Composita.

Syn.-Catsfoot, Gnaphalium dioicum, Linn.

Part used-Herb.

Action-Astringent. Used as a gargle or injection; internally as a styptic in looseness of bowels, \&c.

Distinctive character-The herb is $4-8$ inches high, with obovate, spatulate root-leaves, which are smooth above, but cottony beneath. Stems cottony. Flowerheads hemispherical, shortstalked, terminal, in clusters of four or five together almost hidden by the long hairy pappus; the male with white, the female with rose coloured membranous scales (phyllaries). Taste, astringent. Odour, pleasant, stronger in the female heads. The flowerheads, with about I inch of the flowerstalk, are usually sold under the name of Catsfoot.

LIFE ROOT.

Senecio aureus, Linn.

N.O. Composite.

Syn.-Squaw-weed, Golden Senecio.

Parts used-Herb, root.

Action-Emmenagogue, diuretic, pectoral, astringent, tonic. A most useful plant deserving of careful attention. 
For suppressed menstruation it is considered by many as a specific, and given in conjunction with other remedies there is no doubt it has a certain and effectual action. In the first stages of consumption it is often used, as its tonic properties, combined with the pectoral, have a very beneficial effect. It is also valuable in gravel, stone, diarrhœa, \&c. In suppression of menstruation, $\frac{1}{2}$ ounce of powder or fluid extract in I pint of water is taken in wineglassful doses four times a day until the desired effect is produced. In pulmonary complaints, I teaspoonful of the fluid extract should be taken in sweetened water or combined with other pectorals.

Preparations-Powdered root: Dose, $\frac{1}{2}-I$ drachm. Solid extract: Dose, 5-Io grains. Fluid extract: Dose, $\frac{1}{2}-1$ drachm. Senecin: Dose, I-3 grains.

Distinctive character-Stems slender, fluted, I-2 feet high, cottony, unbranched. Rhizome I-2 inches long, resembling arnica in size, but with more numerous roots, the bark of the roots hard and blackish surrounding a ring of short white wood bundles, which enclose a large dark-coloured pith. Root-leaves ovate, reniform up to 6 inches long, with long leafstalks. Stem-leaves decreasing in size upwards, incised and pinnatifid, and the upper ones sessile. Flowerheads few, in a loose corymb, $\frac{2}{3}$ to nearly I inch broad, and about half as long. Florets of the ray golden yellow, slightly reflexed, pistillate; the central tubular florets hermaphrodite. Pappus pilose. Taste, bitter, astringent, slightly acrid. Odour, feeble.

\section{LILY-OF-THE-VALLEY.}

Convallaria majalis, Linn. N.O. Liliacea.

Syn.-Convallaria, May Lily.

Parts used-Root, herb, flowers.

Action-Cardiac tonic, diuretic. Its action closely resembles Foxglove, without causing unpleasant dis- 
turbances. In larger doses it causes emesis and purgation. Has been used in dropsy and cardiac debility. Is strongly recommended in valvular heart disease. The infusion of $\frac{1}{2}$ ounce of herb to a pint of boiling water is taken in tablespoonful doses.

Preparations-Fluid extract, herb: Dose, I0-30 drops. Fluid extract, whole plant : Dose, 10-30 drops. Fluid extract, flowers: Dose, $\frac{1}{2}-\mathrm{I}$ drachm.

Distinctive character-Leaves broadly lanceolate, 4-6 inches long by $\mathrm{I} \frac{1}{2}-2 \frac{1}{2}$ inches wide, parallel-veined, and entire at the margins. Flowering stem distinct, bearing eight to twelve stalked, small bell-shaped white flowers, with six stamens and a superior ovary, sweetscented when fresh. Rhizome slender, the internodes about 2 inches long and $I_{1}^{\frac{1}{2}}-1 \frac{1}{8}$ inch thick, cylindrical, pale brown, bearing at each joint eight or ten slender, branched, long rootlets. Taste, gummy, sweetish and bitterish, then acrid. Odour, pleasant.

\section{LIME FLOWERS.}

Tilia Europaa, Linn. N.O. Liliacea.

Syn.-Lindenflowers, Linnflowers. T. platyphylla, Scop., T. cordata, Mill., T. vulgaris, Heyne.

Part used-Flowers.

Action-Nervine, stimulant, tonic. This is a common domestic remedy for nervous and catarrhal disorders following upon colds. It is also of service in restlessness, headaches, indigestion, and hysteria. The hot infusion of I drachm in a pint of boiling water is useful in checking diarrhœea from cold. Sometimes a bath is prepared in similar strength and the patient immersed therein to produce sleep.

Distinctive character-These flowers are really derived in commerce from more than one species of Tilia, the European species of which are closely allied. Tilia platyphylla, Scop., has cordate leaves, hairy beneath, 
and doubly serrate, and an oblong, obtuse bract attached to the lower third of the flowerstalk. The flowerstalk bears about three to six yellowish white five-parted flowers, with numerous stamens, at the apex of which the two anther cells are separated on short divergent stalks.

In Southern Europe the flowers of $T$. argentea, Desf., are used. They differ by their petals bearing staminodes on their inner surface, and in the jonquil-like odour of the flowers.

LIMEFRUIT.

Syn.-Citrus acris, Mill.

Parts used-Fruit, juice.

Action-Refrigerant, antiscorbutic. The juice is popularly used as a beverage, by itself, sweetened as a syrup, or in conjunction with alcoholic beverages.

Distinctive character-The lime fruit exists in several varieties. The limes usually imported into this country resemble the lemon in colour and appearance, but are nearly globular instead of oval, and average only about $\mathrm{I} \frac{1}{2}$ inch in diameter. The flavour of the rind is slightly different from that of the lemon, but the juice is equally acid.

Citrus Limetta, Risso, is stated to have an insipid juice.

LINSEED.

Syn.-Flaxseed.

Part used-Seed.

Action-Pectoral, demulcent, emollient. Is largely used as an addition to cough medicines, \&c. The infusion of 1 ounce of seed to a pint of boiling water, and 
sweetened, may be taken in wineglassful doses. The crushed seeds make a valuable poultice in bronchitis, alone or with mustard. The addition of a little powdered Lobelia Seed makes it of value in ulcers, boils, \&c. The oil is used externally as an application for burns, scalds, \&c.

Distinctive character-The seed varies much in size and in tint, a yellowish variety occurring in India. The English and Dutch varieties are usually imported as being more free from weed seeds and dirt. If containing more than 4 per cent. of weed seeds, linseed may be considered to be adulterated. Of English and Dutch seeds, about twelve weigh one grain, but of some of the Indian and Mediterranean varieties, which are nearly twice as large, about six weigh one grain. The seed is brown, oval, pointed at one end, polished, and $\frac{1}{6}-\frac{1}{4}$ inch long. The taste is mucilaginous and slightly unpleasant. Inodorous, except when powdered. The seeds yield about 6 per cent. of mucilage, which is contained in the seed coat. The seed itself contains oil. The meal of the seeds is sold in two forms, viz., crushed linseed, and linseed meal made by powdering linseed cakes from which the oil has been expressed. The former is preferable for poultices.

LIPPIA.

Lippia dulcis, Trev.

Syn.-Yerba dulce. Mexican Lippia.

N.O. Verbenaca.

Part used-Leaves.

Action-Demulcent, expectorant. It is an excellent remedy in coughs, colds, whooping cough, and bronchial affections in general. It also seems to act upon the bronchial mucous membrane as an alterative.

Distinctive character-The leaves of Moxican Lippia are derived from Lippia dulcis, Trev. They are $1 \frac{1}{2}-2$ inches long, ovate, narrowed into the petiole, pointed, serrate above, with prominent veins and are glandular hairy. The odour and taste are agreeably aromatic. 
LIPPIA CITRIODORA.

Aloysia citriodora, Ort.

N.O. Verbenaca.

Syn._Lemon-scented Verbena, Herb Louisa, Verbena triphylla, L'Herit., Lippia triphylla, L'Hérit.

Uses-The dried leaves are very fragrant and are used in Sachets, \&c.

Distinctive character-The leaves are opposite on the stem, often three in a whorl, or even four, elongatelanceolate, attenuated at both ends, about 3-4 inches long, Is inch wide in the middle, with the lateral veins almost at a right angle to the midrib. When rubbed they give off a lemon odour. The taste resembles that of the lemon.

\section{LIQUORICE ROOT.}

Glycyrrhiza glabra, Linn.

Syn,-Licorice.

N.O. Leguminosa.

Part used-Root.

Action-Demulcent, pectoral, emollient. One of the most popular and well-known remedies for coughs, consumption, and chest complaints. Beach mentions the following recipe as being used by the late Dr. Malone, of London, and speaks most highly of its efficacy.

"Take a large teaspoonful of Linseed, I ounce of Liquorice Root, and $+\mathrm{lb}$. of best raisins. Put them into 2 quarts of soft water and simmer down to I quart. Then add to it $\frac{1}{4} \mathrm{lb}$. of brown sugar candy and a tablespoonful of white wine vinegar or lemon juice. Drink $\frac{1}{2}$ pint when going to bed and take a little whenever the cough is troublesome."

N.B.-It is best to add the vinegar to that quantity which is required for immediate use.

Liquorice is one of the best covers for bitter vegetable medicines such as Cascara, \&c.

Preparations-Powdered root: Dose, $\frac{1}{2}-1$ drachm. Compound lozenges U.S.P. Solid extract: Dose, I 
drachm. Fluid extract: Dose, I-4 drachms. Compound powder B.P.: Dose, I-2 drachms. Solid extract in form of sticks is known as Liquorice Juice.

Distinctive character-The root varies in size and character. The English-grown root is usually sold fresh. It is greyish brown externally, with transverse scars, and internally yellowish and fibrous. The transverse section shows a radiate structure. The taste is sweetish, and the odour, when chewed, pea-like, but characteristic. The root of commerce often contains, especially the Spanish and Russian sorts, a large proportion of underground stem, which is less sweet and can be recognised by the absence of transverse scars, and the presence of a central pith. The Russian and Persian Liquorice are often in large pieces, $\frac{3}{4}-\mathrm{I}$ inch or more in diameter, and has a red-brown scaly surface, and a slight bitterness and acridity. They are derived from G.glabra, var., glandulifera, W. and K. The Russian sort is also sold in a decorticated state.

\section{LITMUS. Roccella tinctoria and R. Montagnel, D.C.}

Syn.-Lacmus, Persio.

N.O. Lichenes.

Part used-Pigment.

Used as an analytical indicator. The prepared Litmus is made into various forms, such as papers or tinctures, and as such used in chemistry for testing purposes. The blue colour, which is natural, has the property of turning to red whenever substances of an acid character are brought into contact with it. This acquired red colour will again return to blue in contact with alkalies. This colouring matter is of a pure deep blue colour, and is usually sold in the form of small cubes, or in a prepared solution. It is prepared from Roccella tinctoria, D.C., and R. Montagnei, D.C.

Cudbear is a purplish red powder prepared from Lecanora tartaroa, Ach., and L. parella, Ach., and Archil or Orchil is an ammoniacal, reddish purple liquid preparation made from the same lichens. 


\section{LIVERWORT, AMERICAN.}

Anemone hepatica, Linn.

N.O. Ranunculaca.

Syn.-Kidneywort, Liverleaf, Hepatica triloba, Choisy.

Part used-Herb.

Action-Tonic, astringent, pectoral. A mild remedy in disorders of the liver, indigestion, \&c. Possessing pectoral properties, it may be used in coughs, bleeding of the lungs, and chest diseases. The infusion of I ounce to a pint of boiling water is taken in doses of $\frac{1}{2}$ teacupful frequently.

Preparation-Fluid extract: Dose, $\frac{1}{2}-2$ drachms.

Distinctive character-The leaves are long-stalked, leathery, smooth, dark green above, rounded, about 2 inches in diameter, with three broad angular lobes. Flowers solitary. Fruit of several achenes. Taste, slightly astringent and bitterish. Inodorous.

LIVERWORT, ENGLISH. Peltigera canina, Hoffm. N.O. Lichenes.

Syn.-Liverwort, Ground Liverwort, Lichen caninus.

Part used-Lichen.

Action-Deobstruent, slightly purgative. Held in esteem as a remedy for liver complaints, but is generally combined with other remedies. Was believed to be a specific against rabies, but has fallen into disuse. The infusion of I ounce to a pint of boiling water is taken in wineglassful doses, repeated frequently.

\section{Preparation-Fluid extract: Dose, $\frac{1}{2}-2$ drachms.}

Distinctive character-This lichen has rounded lobes, an unequal surface, and greyish colour, and is downy above, but beneath is whitish, with pale nerves and white rootlets. The fruit, when present, forms blackish oblong spots on the tips of the upper surface. 
Syn.-Indian Tobacco, Puke Weed.

N.O. Campanulaceo.

Parts used-Herb, seeds.

Action - Expectorant, emetic, diaphoretic, antasthmatic, stimulant. This plant is extensively employed, and is regarded as one of the most valuable remedies ever discovered. It is chiefly used as an emetic, and may be prescribed wherever one is indicated. In bronchial troubles and pulmonary complaints its action is speedily and wonderfully beneficial. All accumulation of mucus is instantly removed after a full dose of the infusion, and many lives have been saved by its timely use. In croup, whooping cough, and asthma it is specially valuable, and it may be regarded as certain to give relief in the distressing paroxysms which characterise the last-named disease ; in fact it may be used wherever there is bronchial spasm. In cases of infantile cough and bronchitis, when the child seems likely to be suffocated by phlegm, a dose will remove obstruction. Dr. Thomson recommends Lobelia in nearly every complaint, and there is no doubt of its general applicability in some way to most diseases. In liver or stomach troubles an emetic of Lobelia will remove all immediate obstructions, and pave the way for the use of other remedial medicines. Mixed with powdered Slippery Elm it forms a stimulating poultice for inflammations, ulcers, swellings, \&c. The infusion of I ounce of powdered herb in a pint of boiling water may be taken in doses of $\frac{1}{2}-\mathrm{I}$ wineglassful.

Preparations-Powdered herb: Dose, 5-60 grains. Fluid extract: Dose, Io-2o drops. Solid extract, alc. : Dose, 2-4 grains. Acid tincture: Dose, I-4 drachms. Tincture U.S.P.: Dose, I-4 drachms. Ethereal tincture B.P.: Dose, 5-15 drops. Syrup: Dose, I-4 drachms. Oil of seed: Dose, I drop rubbed well up with 20 grains of sugar, and divided into 6-1 2 doses. Lobelin: Dose, 1-3 grains.

Distinctive character-Stem slightly hairy, angular. Leaves alternate, I-3 inches long, sessile, ovate- 
lanceolate, obscurely toothed, with small whitish glands on the edge. The fruit consists of a flat oval capsule containing a number of minute ovate-oblong, brown seeds, about $\frac{1}{8}$ inch long with a reticulated, pitted surface. Taste, burning, acrid, like that of tobacco. Odour, slight.

LOGWOOD. Haematoxylon Campechianum, Linn.

Syn.-Haematoxylon.

N.O. Leguminosa.

Part used-Wood.

Action-Astringent. Being less constipating than other astringents, this drug may be used in old diarrhœas, dysentery, hæmorrhages from lungs, uterus, and bowels, infantile diarrhœa, \&c. The decoction may be freely given in doses of a wineglassful when required, or the solid extract in the form of pills.

Preparations - Decoction B.P., I895: Dose, $\frac{1}{2}-2$ ounces. Extract solid B.P., I885: Dose, I0-30 grains. Solid extract U.S.P.: Dose, 2-5 grains.

Distinctive character-Logwood is usually sold in the form of chips for dyeing purposes, and has a dark, purplish-brown colour and a greenish iridescence, which indicates that it has been submitted to fermentation. For medicinal purposes the unfermented chips, which have a bright, reddish-brown tint, are preferable. It can also be obtained in the form of extract.

LOOSESTRIFE. Lysimachia vulgaris, Linn. N.O. Primulaced.

Syn.-Yellow Loosestrife.

Part used-Herb.

Action-Astringent, expectorant. Useful in bleeding of mouth, nose, and wounds. It restrains profuse 
menstruation. As a gargle it finds use in relaxed throat, \&c.

Distinctive character-The herb is $2-3$ feet high, bearing opposite leaves, or sometimes three together, elongate-lanceolate, nearly stalkless, 3-6 inches long by I 1 inch broad, with short, spreading, soft hairs, especially on the stem and veins beneath the leaf. Flowers yellow, about $\frac{3}{3}$ inch in diameter, in axillary and terminal panicles. Taste, astringent, slightly acid. Odour, none.

LOVAGE.

Levisticum officinale, Koch. N.O. Umbellifera.

Syn.-Ligusticum Levisticum, Linn.

Part used-Root.

Action-Diuretic, carminative. Used in febrile affections and in stomach disorders.

Distinctive character-The rootstock or upper portion, usually about $\mathrm{I} \frac{1}{2}$ inch long and $2 \frac{3}{4}$ inches thick, sometimes shows leaf-scales at the apex, with annular rings below it, and lateral branches $2-4$ inches long and $\frac{1}{4}-\frac{1}{2}$ inch in diameter. The external surface is greyish brown and in the rootlets is furrowed longitudinally. The bark of the root is thick, spongy, and whitish, occupying nearly half the diameter, and is separated by a darker line from the woody centre, which is radiate and yellowish, and glistening oil cells are visible in the transverse section. In the outer part of the root bark there are often small cavities. It has a sweet, slightly bitter taste, and a flavour like that of fenugreek.

\section{LUCERNE.}

Part used-Whole Herb.

Action-Lucerne is given to cattle for fattening purposes. In medicine the infusion of I ounce to the pint 
in cupful doses is prescribed for increasing the weight and to put on flesh.

Distinctive character-Herb about $I_{\frac{1}{2}}$ foot high. Leaves trifoliate. Leaflets obovate, emarginate, mucronate, dentate above, about $\frac{3}{2}$ inch long and $\frac{1}{1}$ inch broad, with veins at an acute angle and appressed hairs. Flowers, when present, usually blue, in a many-flowered raceme. Pods loosely spiral with two to three turns, with appressed hairs.

LUNOWORT.

Sticta pulmonaria, Linn.

N.O. Licheres.

Syn.-Oak Lungs, Lung Moss.

\section{Part used-Herb.}

Action-Astringent, mucilaginous, pectoral, healing. Especially valuable in the treatment of coughs, lung complaints, asthma, \&c. It heals the parts affected and takes away inflammation. The infusion of $I$ ounce in a pint of boiling water is taken in frequent doses of a wineglassful.

Preparation-Fluid extract: Dose, $\frac{1}{2}-\mathrm{I}$ drachm.

Distinctive character-This lichen is flat, greyish or greenish brown, leathery, branched in a forked manner, the lobes about $\frac{1}{2}$ inch broad, decreasing to $\ddagger$ inch towards the circumference. The upper surface is reticulated with small concavities, which on the lower surface are evident as corresponding whitish concavities. Taste, mucilaginous, bitter, and a little acrid. Odour, characteristic.

MACE.

Syn.-Avillus Myristica.

Action-Stimulating, carminative. Used chiefly as a flavouring agent in cookery and medicine. The 
powdered Mace may be used in doses from 5-20 grains.

Distinctive character-The arillus known as Mace is a growth outside the shell of the nutmeg seeds. It is about $\mathrm{I} \frac{8}{4}$ inch long and $\frac{1}{20} \cdot \frac{1}{10}$ inch thick, irregularly branched, when dry of an orange-brown colour, has a horny, translucent appearance, but is brittle, and exudes oil when pressed by the nails. Taste, strongly aromatic, pungent. Odour, characteristic.

Two other varieties of Mace occasionally appear in commerce, viz., Bombay Mace (Myristica Malabarica, Lam.), which is nearly tasteless and of a redder colour ; and Macassar Mace (Myristica argentea, Warb.), which is very acrid, and unfit for medicinal use.

MADDER.

Rubla tinctorum, Linn.

N.O. Rubiacea.

Syn.-Dyer's Madder, Garance (Fr.).

Part used-Root.

Action-Although not used generally in medicine, this has at various times been reputed effectual for promoting menstrual and urinary discharges. Its principal use is found in the technical arts as a dyestuffTurkey red. Rubia sylvestris has been used as a remedy in liver diseases, jaundice, gall, and spleen complaints. Root, leaves, and seeds are all reputed as medicinally active.

Distinctive character-The root, as met with in commerce, consists of short cylindrical pieces about $\frac{1}{8}-\frac{1}{6}$ inch in diameter, with a thin, easily-detached, corky layer, leaving a red-brown, longitudinally-furrowed inner bark. The transverse section shows a pale red column, marked with concentric striæ. Taste, sweetish, then acrid. Odour, slight. 
MAGNOLIA.

Magnolia Virginiana, Linn.

N.O. Magnoliacea.

Syn.-Magnolia glauca, Linn., also $M$. acuminata and M. tripetata.

\section{Part used-Bark.}

Action-Stimulant, tonic,-aromatic, diaphoretic. A popular remedy for rheumatism. Used also in malaria.

Preparations-Powder in warm infusion: Dose, $\frac{1}{2}$-I drachm. Fluid extract :. Dose, $\frac{1}{2}$-I drachm.

Distinctive character-The bark occurs in long, fibrous strips, 6-1 2 inches long, and $\frac{8}{4}-\mathrm{I}$ inch broad, with the corky part removed, the outer surface rough, and almost granular, and coarsely pitted, the inner surface striated, but nearly smooth. Fracture shortly fibrous, except the inner portion, which is formed of tough, fibrous layers. Taste, slightly astringent and irritating. Odour, none.

MAIDENHAIR. Adiantum Capillus=Veneris, Linn.

Part used-Herb.

N.O. Filices.

Action-Mucilaginous, pectoral, expectorant. Is used as a popular cough medicine throughout most parts of Europe. In France large quantities are employed in the preparation of the well-known "Sirop de capillare." It may be used in all coughs, throat affections, and bronchial disorders. The infusion of I ounce to a pint of boiling water may be taken frequently in wineglassful doses. To improve taste add sugar.

Distinctive character-Stem slender, black, shining. Frond repeatedly forked, bearing short, wedge-shaped leaflets with forked veins, and membranous indusia covering the spore-cases at the outer edge of the under surface of the incised leaflets. Taste, sweetish and a little astringent. Odour, weak. 
Syn.-Adatodai, Arusa, Adulsa, Bákas, Justicia Adhatoda, Linn.

\section{Part used-Leaves.}

Action-Antispasmodic, expectorant, febrifuge. In India this drug is highly esteemed as a remedy in all bronchial, asthmatic, and pulmonary diseases. It is mostly administered in the form of an infusion, although in asthma the leaves are sometimes smoked. European practitioners have used it with success in intermittent and typhus fevers, and also in diphtheria.

Preparations-Fluid extract Br. Add. : Dose, 20-60 minims. Tincture Br. Add. : Dose, $\frac{1}{2}-\mathrm{I}$ drachm.

Distinctive character-The leaves are opposite, short stalked, lanceolate, entire, taper-pointed, 5-6 inches long and $\mathrm{I} \frac{1}{2}$ inch broad, smooth on both sides. Taste, bitter. Odour, tea-like.

MALE-FERN.

Dryopteris Fllix-mas, Linn. N.O. Filices.

Syn.-Aspidium Filix-mas, Schwartz., Male Shield Fern.

Part used-Root.

Action-Tænifuge, vermifuge, anthelmintic. Mostly used for expulsion of tapeworm. The powder or the fluid extract may be taken, but the ethereal extract or oleoresin, if given in pill form, is the more pleasant way of taking it. The last dose should be followed by a purgative of castor oil.

Preparations-Powdered root: Dose, I-4 drachms. Fluid extract: Dose, I-4 drachms. Oleoresin: Dose, 5.20 drops. Ethereal extract B.P.: Dose, $45-90$ drops. 
Distinctive character-The dried rootstock averages about $1 \frac{1}{2}-2 \frac{1}{2}$ inches in diameter and about 3 inches long, and consists, as met with in commerce, of the scaly leaf-bases attached to the rhizome, and trimmed free of rootlets. The transverse section shows Io large wood bundles in a ring, and some scattered smaller ones, but the leaf base shows only eight, forming an irregular circle. It is reddish brown externally, and somewhat greenish internally. Taste, bitterish, sweet, acrid, and astringent. Flavour and odour, unpleasant.

MANACA.

Brunfelsia Hopeana, Hook. N.O. Solanacea.

Syn.-Franciscea unifora, Pohl.

Part used-Root.

Action-Alterative, diuretic, antirheumatic. Used as a rheumatic remedy in South America. Is considered a most valuable alterative in scrofula, syphilis, and rheumatic arthritis. A decoction of I ounce in a pint of water is taken in tablespoonful to wineglassful doses.

Preparation-Fluid extract : Dose, Io-6o drops.

Distinctive character-The root occurs in pieces about 4-6 inches in length, with a pale brown, papery epidermis. The transverse section shows a thin, dark brown bark about $\frac{1}{16}$ inch thick, and several concentric rings of wood traversed by slender medullary rays. Taste, sweetish and faintly aromatic.

\section{MANDRAKE, AMERICAN.}

Podophyllum peltatum, Linn. N.O. Berberidacea.

Syn.-May Apple, Racoon Berry, Wild Lemon.

Parts used-Root, resin.

Action-Antibilious, cathartic, hydragogue, purgative. Mandrake is a powerful medicine, exercising an influence 
on every part of the system, stimulating the glands to a healthy action. Its most beneficial action is obtained by the use of small doses frequently given, as large ones cause violent evacuations and debility. In all chronic venereal, scrofulous, and dyspeptic complaints it is highly valuable; also in dropsy, biliousness, and liver disorders.

Preparations of the root are to be preferred to those of the resin. This is one of the many illustrations of the fact that isolated principles do not act so well as in their natural position where they are associated with other remedial factors.

Preparations-Powdered root: Dose, 5-30 grains. Solid extract: Dose, I-5 grains. Fluid extract: Dose, 5-30 drops. Tincture, root: Dose, I 5-30 drops. Tincture, resin B.P.: Dose, 5.I5 drops. Podophyllin, resin: Dose, $\frac{1}{4}-I$ grain.

Distinctive character-The rhizome is of a reddish brown colour, and occurs in pieces of 3 or more inches long, usually smooth, with knotty joints at intervals of about $I \frac{1}{2}-2$ inches, having a depressed stem scar above, and a few brittle roots beneath it. Fracture mealy, whitish, showing 20.40 yellow wood bundles enclosing a central pith. This drug must be carefully distinguished from English Mandrake (see Bryonia dioica).

MANNA.

Fraxinus Ornus, Linn.

Syn.-Flake Manna.

N.O. Oleacea.

Part used-Concrete exudation.

Action-Nutritive, laxative. A useful laxative for children and infants, and for females during pregnancy, May be used alone in doses of a teaspoonful up to I or 2 ounces, or combined with other laxatives and carmina. tives.

Distinctive character-A saccharine exudation from the incised bark of the tree. In pale yellowish or 
whitish pieces, irregular on one side and smoother and curved on the other, rarely more than I inch broad and 2-3 inches or more long. Taste, sweet, honey-like, without bitterness. Odour, slight.

MAPLE, RED.

Syn.-Swamp Maple.

Part used-Bark.

Action-Astringent. Used by American Indians as an application to sore eyes.

Distinctive character-In long quilled pieces 6-12 inches or more and $\frac{1}{4}-\frac{3}{4}$ inch wide, externally blackish brown, slightly polished, with innumerable fine transverse lines, and scattered, brownish, small warts. Inner bark, in very tough and fibrous layers, pale reddish brown or buff. Taste, astringent and faintly bitter.

MARIGOLD.

Calendula officinalis, Linn. N.O. Composita.

Syn.-Caltha officinalis, Marygold, Garden Marigold, Calendula.

Parts used-Flowers, herb.

Action-Stimulant, diaphoretic. Chiefly used as a local remedy. Given internally it assists the local action and prevents suppuration. Useful in chronic ulcers, varicose veins, \&c. The infusion of I ounce to a pint of boiling water may be taken in doses of a tablespoonful or wineglassful, and used as an application for external purposes.

Preparations-Fluid extract: Dose, $\frac{1}{4-1}$ drachm. Tincture U.S.P. Calendulin: Dose, I-3 grains.

Distinctive character-Stem angular and, as well as the leaves, pubescent. Lower leaves spatulate with 
a large stalk, the upper sessile amplexicaul terminated by a small obtuse point. The flowerheads yellow, with the tubular florets sterile. Fruit semi-circular, rough, angular, without pappus. Taste, bitter. Odour, strong and unpleasant.

MARJORAM, SWEET. Origanum Majorana, Linn. N.O. Labiata.

Syn.-Majorana hortensis, Mœnch.

Parts used-Herb, leaves.

Action-Tonic, emmenagogue, stimulant. Hardly ever used for medicinal purposes, but is employed in cookery as a seasoning. The volatile oil-Oleum majovane-is an excellent external application for sprains, bruises, \&c.

Distinctive character-The herb is about Io inches high, branched above, with opposite, whitish, small, oval-obtuse leaves, about $\frac{1}{2}$ inch long and $\frac{1}{3}$ inch broad, and small flowers almost hidden by green bracts arranged in small, hop-like, rounded spikes or heads forming a terminal panicled cyme. Flowers white or pink, with the calyx open like one of the bracts. Taste, aromatic, agreeable.

MARJORAM, WILD.

Origanum vulgare, Linn.

Parts used-Herb, oil. N.O. Labiata.

Action-Emmenagogue, stimulant. The whole herb is medicinal and contains a volatile oil, which is separated by distillation. Perspiration may be produced by a warm infusion, and this is also taken to promote the menstrual flow, when suppressed by cold. The oil is stimulant and rubefacient, and often used as a liniment.

Distinctive character-Herb, with opposite-stalked, usually entire leaves which are ovate, hairy, but not 
whitish. The purplish flowers are arranged in oval or oblong heads, with usually pink bracts, and the calyx is tubular and five-toothed. Taste and odour, thymelike. The oil sold under the name is distilled from Thymus vulgaris, Linn., in France; that of the Wild Marjoram, Origamum vulgave, is not an article of commerce.

MARSHMALLOW.

Althaea officinalis, Linn.

N.O. Malvacea.

Syn.-Mallards, Guimauve, Mauls, Schloss Tea.

Parts used-Leaves, root.

Action-Demulcent, emollient. This plant constitutes a popular remedy for coughs, bronchitis, \&c., generally in combination with other remedies. In painful complaints of the urinary organs, gonorrhœea, cystitis, it exerts a relaxing effect upon the passages as well as acting as a curative. The powdered or crushed fresh roots make a good poultice, which may be relied upon to remove the most obstinate inflammation and prevent mortification. Its powers in this direction are so great that it has been termed Mortification Root. The addition of Slippery Elm is an advantage, and it should be applied to the part as hot as can be borne, renewing the poultice when dry. An infusion of I ounce of leaves to a pint of boiling water is taken frequently in wineglassful doses.

Preparation-Fluid extract,leaves: Dose, $\frac{1}{2}-2$ drachms.

Distinctive character-The root is greyish white externally, with transverse scars, internally white and fibrous. It is generally sold in the decorticated state, when the outer surface is fibrous and white. . It has deep longitudinal furrows due to drying, and tapers gradually below. Taste, mucilaginous, mawkish. Odour, slight. It should be kept dry or will give a yellowish decoction of unpleasant odour. The leaves are greyish green and velvety, due to a dense covering of stellate 
hairs, cordate-ovate, pointed, irregularly serrate at the margins, about $2 \frac{1}{2}$ inches long and I inch broad, brittle when dry. Flowers pink, with the stamens united into a tube, and the anthers kidney-shaped and one-celled. The calyx has eight linear bracts attached to its outer surface.

MASTERWORT. Imperatoria Ostruthium, Linn.

Part used-Root.

N.O. Umbellifera.

Action-Stimulant, antispasmodic, carminative. Recommended in asthma, apoplexy, and menstrual complaints. Has also been of use in flatulence and dyspepsia. A decoction of $\mathrm{I}$ ounce to a pint of water is taken in wineglassful doses.

Preparation-Fluid extract: Dose, I-2 drachms.

Distinctive character-Rhizome cylindrical, compressed, knotty at intervals of about $\frac{1}{2}$ inch, $2-4$ inches long and $\frac{1}{2}-\frac{3}{4}$ inch in thickness, with few scattered roots and scattered, rounded warts, sometimes in shorter, conical, compressed pieces, some pieces terminating in nearly smooth underground suckers about $\frac{1}{1}$ inch in diameter. Fracture short, hard and tough, showing a central pith surrounded by a circle of oil cells, another circle of similar cells occurring in the bark. Taste and odour, ivy-like but pungent.

MASTIC.

Syn.-Mastich, Lentisk.

Part used-Resin.

Use-The resin by itself or in a spirituous solution is used in dentistry as a filling for carious teeth. In 
the technical arts it is used for the manufacture of varnishes, cements, \&c.

Distinctive character-The resin occurs in small, rounded, or lenticular, transparent tears which, when masticated, forms a dough-like mass, unlike gum sandarac, which is in cylindrical tears and goes to powder when chewed. Taste, cedar-like. Odour, slight.

MATICO.

Piper angustifolium, R. and P.

Syn.-Artanthe elongata, Miq.

N.O. Piperacea.

Part used-Leaves.

Action-Astringent, stimulant, diuretic. Has been recommended and used in leucorrhœa, gonorrhoea, piles, and chronic mucous discharges. Also in bleeding from the lungs, dysentery, and other hæmorrhages. Its action is very similar to that of cubebs. The infusion of I ounce to a pint of boiling water is taken in wineglassful doses.

Preparation-Fluid extract: Dose, $\frac{1}{2}$-I drachm.

Distinctive character-Leaves usually more or less broken, but easily recognised by their surface being reticulated on both sides, convexly on the upper surface, due to the deeply sunk veinlets, and the under surface being similarly tessellated with corresponding minute depressions clothed with shaggy hairs. The stems are slender and, as well as the hairs, have knotted joints. Taste, aromatic and bitterish. Odour, herbaceous.

MAYWEED.

Anthemis Cotula, Linn.

N.O. Composita.

Syn._Maruta Cotula, D.C., Maruta fotida, Cass., Wild Chamomile, Dog Chamomile, Dog Fennel, Cotula.

Part used-Herb.

Action-Tonic, antispasmodic, emmenagogue, emetic. Has been used with success in sick headache, in con- 
valescence from fevers, and in amenorrhœa. The warm infusion of I ounce in a pint of boiling water is taken in wineglassful doses when required.

Distinctive character-The herb resembles chamomile in appearance, but the white flowers have not membranous scales at their base. When the florets are pulled off there remain only a few bristly paleæ on the top of the conical receptacle. The outer florets have usually no styles. Taste, disagreeable and acrid. Anthemis arvensis, Linn., a common cornfield weed, has lanceolate paleæ, and the white florets of the ray have always styles.

MEADOW LILY.

Lilium candidum, Linn. N.O. Liliacea.

Syn.-White Lily, Madonna Lily.

Part used-Bulb.

Action-Mucilaginous, demulcent, astringent. Combined with Life Root it is of value in treating leucorrhœea, prolapse of the womb, and female complaints generally. The fresh bulb has been used with success in dropsy. A decoction of the bulb in water or milk is taken internally in wineglassful doses. Externally the latter forms a useful cataplasm for tumours, ulcers, and external inflammations.

Distinctive character-The bulb consists of free, fleshy scales, lanceolate and curved, about $\mathrm{I}_{\frac{1}{2}}$ inch long, and rather less than $\frac{1}{2}$ inch broad in the centre. Taste, mucilaginous, bitter, and unpleasant.

MEADOWSWEET.

Spiraea Ulmaria, Linn. N.O. Rosacea.

Syn.-Queen-of-the-meadow Herb, Bridewort, Ladyof-the-meadow, Dolloff.

Part used-Herb.

Action-Aromatic, astringent, diuretic. Has a pleasant taste and is incorporated in many herb beers. 
A good remedy in strangury, dropsy, \&c., and in children's diarrhœa, for which alone it may be deemed a specific. The infusion of $I$ ounce to a pint of water is taken in wineglassful doses.

Preparation-Fluid extract: Dose, $\frac{1}{2}$-I drachm.

Distinctive character-The leaves are interruptedly pinnate, having a few large serrate leaflets and very small intermediate ones, dark green above and whitish and downy beneath, the terminal lobes larger and three to five-lobed. Flowers small, yellowish white, in large, irregularly-branched, dense cymes. Taste, astringent and slightly aromatic.

\section{MELILOT.}

Syn.-King's Clover.

Part used-Herb.

Action-Aromatic, emollient, carminative. Relieves flatulence and is taken internally for this purpose. Externally it is applied as a fomentation or poultice for pains and aches.

Distinctive character-Two species are sold under this name. Both have trifoliate leaves and yellow flowers, but $M$. arvensis, Lamk., has small, glabrous, one to two-seeded pods, and $M$. officinalis, Willd., has hairy pods. The leaves are obcordate, serrate in the former, and ovate-truncate in the latter. Taste and odour, like hay.

MESCAL-BUTTONS.

Lopophora Lewinil, Henn. N.O. Cactacea. Syn.-Muscal Buttons, Pellote, Anhalonium Lewinii, Henn.

Part used-Fruit.

Action-Cardiac tonic, emetic, narcotic. This drug has been reputed as a remedy in all paroxysmal com- 
plaints, dyspnœea, angina pectoris, \&c. It should be used with caution, as it causes emesis in even small doses.

Distinctive character-The dried tops of this Cactus are about $1 \frac{1}{4}-\frac{1}{2}$ inch in diameter and about $\frac{1}{3}$ inch thick, the centre covered with white silky tufts of hairs, with a few solitary tufts scattered over the surface. It is from these tufts that the small vase-shaped pink flowers arise, but the flowers and fruits are not often seen in the drug. Fracture short and horny, pale brown. Taste, gritty, mucilaginous, slightly acrid, pungent, and bitterish.

MEZEREON.

Daphne Mezereum, Linn.

N.O. Thymelcacea.

Syn.--Spurge Olive, Spurge Laurel.

Parts used-Bark, root, rootbark.

Action-Stimulant, alterative, diuretic. Acts favourably in syphilis, scrofula, and rheumatism. The decoction of $\frac{1}{2}$ ounce in a pint of water is taken in wineglassful doses. Externally it is used as a lotion to blistered surfaces, indolent ulcers, \&c.

Preparations-Powdered bark: Dose, ro grains. Fluid extract: Dose, 2-1o drops.

Distinctive character-The root of Daphne Mezereum is brownish, very tough, in branched pieces about $\mathrm{I}-\mathrm{I} \frac{1}{2}$ feet long, the epidermis peeling off when bent and the inner bark consisting of very fine strong fibres. The bark of D. Gnidium, L., which is used in France under the name of "Garou," occurs in commerce in this country, is usually sold in the form of bark only. It has a purplish brown tint, and the stem-bark is slightly hairy. The brown stem-bark of $D$. Laureola, L., which is also sold as Mezereon bark, has the leaf scars crowded at welldefined intervals. Taste, very acrid and caustic. Odour, unpleasant in the fresh state. 
Syn.-European Mistletoe, Birdlime Mistletoe.

\section{Part used-Leaves.}

Action-Nervine, antispasmodic, tonic, narcotic. Has been used with benefit in hysteria, epilepsy, and other nervous diseases. Is of value in uterine hæmorrhages. Dr. Ellingwood thinks it useful in amenorrhœa and dysmenorrhœa, and advises it to be taken as a heart tonic in typhoid fever.

Preparations-Powdered leaves: Dose, $\frac{1}{2}-2$ drachms. Fluid extract: Dose, $\frac{1}{4}-\mathrm{I}$ drachm.

Distinctive character-The leaves are opposite, leathery, rather tough, oblanceolate, about 2 inches long, entire at the margins, with a rounded apex, with four or five longitudinal veins, often with the stems broken at the joints, in pieces about $2 \frac{1}{2}$ inches long. The Mistletoe used in the United States is Phoradendron flavescens, Nutt. It has similar but shorter leaves of a yellower green tint and somewhat pubescent. Taste, insipid. Inodorous.

MONSONIA.

Part used-Plant.
Monsonia ovata, Cav. N.O. Gevaniacea.

Action-A South African remedy for acute and chronic dysentery. Particularly recommended in ulcerated condition of lower bowels.

Preparation-Tincture: Dose, I-2 drachms every three or four hours.

Distinctive character-Stems $I \frac{1}{2}$ foot high, branched with slender spreading hairs. Leaves opposite, stalked, ovate, serrate, about $\frac{1}{4}$ inch long and $\frac{1}{2}$ inch broad, with filiform stipules. Flowers, when present, geranium. 
like, white, axillary, stalked, solitary or two borne on one peduncle. Taste, astringent, slightly aromatic, and faintly acrid.

\section{MOTHERWORT.}

\section{Part used-Herb.}

Action-Antispasmodic, tonic, nervine, emmenagogue. Is especially valuable in female weakness and hysteria, acting as a tonic to the generative organs and allaying nervous irritability. It promotes the flow of the menses, and generally braces up the uterine membranes. It will be found useful as a simple tonic in heart diseases or weakness and in recovery from fevers when other tonics are inadmissible. The infusion of I ounce of herb to a pint of boiling water is taken in wineglassful doses.

Preparations-Powdered herb: Dose, $\frac{1}{2}$-I drachm. Solid extract: Dose, 5-15 grains. Fluid extract : Dose, $\frac{1}{2}$-I drachm.

Distinctive character-Stems square. Leaves stalked, palmately five-lobed, the lobes trifid at apex, coarsely serrate, reticulate veined, the veinlets prominent beneath, with slender curved hairs; the upper leaves trifid, entire, and wedge-shaped below. Flowers pinkish, in whorls in the axils of the upper leaves; calyx teeth rigid and sharp. Taste, very bitter. Odour, none.

MOUNTAIN ASH.

Pyrus aucuparia, Gærtn. N.O. Rosacea.

Syn.-Sorbus aucuparia, Linn., Mespilus aucuparia, Web., Sorbus, Rowan Tree.

Parts used-Fruit, bark.

Action-Astringent. The ripe berries furnish an acidulous and astringent gargle in sore throat and in- 
flamed tonsils. A decoction of the bark is given in diarrhœa, and used as a vaginal injection in leucorrhæa, \&c.

Distinctive character.-The fruit is red and globose, with calyx teeth at the apex, and two to three-seeded cells. The bark has a soft, spongy, yellowish grey outer layer, and an inner thicker portion, with many layers of a light brown colour. The transverse section shows that the layers have abundant stone cells but are without visible radiate structure. Fracture rough, short, and coarsely granular with few fibres. Taste, bitterish. Odour, none.

American Mountain Ash bark is derived from Pyrus Americanus, DC.

MOUNTAIN FLAX.

Syn.-Purging Flax.
Linum catharticum, Linn.

N.O. Linacea.

\section{Part used-Herb.}

Action-Laxative, cathartic. Is preferred to Senna, though the action is very similar. Used in cases of constipation, gravel, dropsy, \&c., generally combined with other herbs. Also recommended in muscular rheumatism and catarrhal affections. The infusion of I ounce in a pint of boiling water is taken in wineglassful doses.

Preparation-Fluid extract: Dose, $\frac{1}{2}-\mathrm{I}$ drachm.

Distinctive character-Stem simple, $2-6$ inches high. Leaves opposite, small, the lower obovate, the upper lanceolate entire. Flowers small, white, five-parted with serrate sepals, and pointed petals arranged in a forked, loose panicle. Taste, bitter and acrid. Odour, none. 
MOUNTAIN GRAPE. Berberis Aquifolium, Pursh. N.O. Berberidacea.

Syn.-Oregon Grape, Holly-leaved Berberry.

\section{Part used-Root.}

Action-Alterative, tonic. Has been justly extolled as an alterative and tonic, as it improves digestion and absorption, and is useful in most diseases arising from impurity of blood. In syphilitic and scrofulous conditions and skin diseases of a scaly character it may be used with advantage. In chronic constipation it is generally used in conjunction with Cascara Sagrada.

\section{Preparation-Fluid extract: Dose, 10-30 drops.}

Distinctive character-The root occurs in pieces averaging about $\frac{s}{4}-I$ inch in diameter, with a thin, greyish yellowish brown bark, internally greenish yellow, and a hard yellowish wood with numerous medullary rays and very short, broken, white, waved lines between them. The rhizomatous part has a small pith. Taste, bitter. Odour, none.

Kalmia latifolia, Linn. N.O. Ericacea. Syn.-Sheep Laurel, Lambkill, Spoonwood, Kalmia. Part used-Leaves.

Action-Cardiac sedative, astringent, alterative. Large doses produce symptoms of narcotic poisoning, but moderate doses-ro-30 grains-are valuable in all febrile complaints and inflammatory diseases. It is regarded as a most efficient remedy in syphilitic disorders, and useful in overcoming obstinate chronic irritation of the mucous membrane. It is also employed with benefit in active hæmorrhages, diarrhœa, and dysentery. The decoction of I ounce in a quart of 
water, boiled down to a pint, is taken in tablespoonful doses.

Distinctive character-Leaves broadly lanceolate, about $2 \frac{1}{2}$ inches long and $1 \frac{1}{4}$ inch broad, leathery, but brittle when dry, with narrowly reflexed entire margins, the midrib prominent on both sides, but the lateral veins obscure. Taste, astringent and tea-like, slightly bitter. Odour, none.

MOUSEAR.

Syn.-Hawkweed, Pilosella.
Hieracium Pllosella, Linn. N.O. Composita.

\section{Part used-Herb.}

Action-Astringent, tonic, expectorant. A good remedy for whooping cough and in all affections of the lungs. The infusion of $I$ ounce in a pint of boiling water is taken in wineglassful doses.

Preparation-Fluid extract: Dose, $\frac{1}{2}-\mathrm{I}$ drachm.

Distinctive character-Leaves forming small rosettes on a creeping stem, elongate-lanceolate, about I $\frac{1}{4}$ inch long and $\frac{1}{4}-\frac{1}{3}$ inch broad, greyish green above, with long, slender, scattered, composite, and serrate hairs, and covered on the under surface with a dense white coat of stellately-branched hairs. Taste, faintly bitter and aromatic. Odour, slight.

MUGWORT.

Syn.-Felon Herb.

Part used-Leaves.

Action-Emmenagogue, diuretic, diaphoretic. Chiefly used in female medicines and for obstruction of men- 
struation, usually in combination with Pennyroyal and Southernwood. The infusion of $x$ ounce to a pint of boiling water is taken in wineglassful doses.

Preparation-Fluid extract: Dose, $\frac{1}{2}-1$ drachm.

Distinctive character-Stem angular, furrowed longitudinally. Leaves dark green above, alternate, pinnatisect, with five to seven lobes, which are semierect, decurrent, deeply incised, with sharply serrate teeth, nearly smooth above, but silvery white, with appressed, bifid, cottony hairs beneath. Taste, bitterish and aromatic. Odour, aromatic.

MUIRA - PUAMA.

Part used-Root.

Action-Aphrodisiac, nerve stimulant. Is reputed in Brazil, its native place, as one of the most powerful aphrodisiacs.

Preparation-Fluid extract: Dose, 10.60 drops.

Distinctive character-The root as met with in commerce occurs in light brown woody splinters $2-3$ inches long and $\frac{1}{4}$ inch in diameter, without any root bark. These splinters are hard, very tough, and coarsely fibrous. The transverse section shows few porous vessels, and crowded slender medullary rays. Taste, slightly astringent. Odour, none.

MULBERRY.

Syn.-Black Mulberry.

Part used-Fruit.

Action-Nutritive, refrigerant, laxative. The fruit juice forms a grateful drink for convalescents from febrile diseases, as it checks the thirst and cools the blood. It was official in B.P. 1885 in the form of
Morus nigra, Linn.

N.O. Urticacea. 
syrup. The bark of the tree is purgative and vermifuge. Leaves of the white variety are used as food for silkworms.

Distinctive character-The fruit of the Black Mulberry only is obtainable in this country. The fruit differs from the blackberry in that it is the product of an agglomeration of flowers, and on each little portion of the fruit the four fleshy lobes of the calyx forming part of it can be detected.

MULLEIN.

Syn. - Blanket Herb.
Verbascum Thapsus, Linn. N.O. Scrophulariacea.

Parts used-Leaves, flowers, root.

Action-Demulcent, astringent, pectoral. Both leaves and flowers are useful in cases of pulmonary diseases, coughs, consumption, bleeding of the lungs and bowels. The infusion of I ounce to a pint of boiling water is taken in wineglassful doses frequently.

Preparation-Fluid extract: Dose, $\frac{1}{2}$-I drachm.

Distinctive character-The basal leaves are lanceolate oblong, the upper more ovate and decurrent. The stem leaves are about 6-8 inches long and $2-2 \frac{1}{2}$ inches broad, densely coated with woolly hairs, which are stellately branched. The corolla, which is the part used, is yellow, cup-shaped, about I inch across with five unequal rounded lobes, to the base of which two nearly smooth and three hairy stamens are attached. The dried corollas turn brownish unless very carefully dried.

MUSKSEED.

Hibiscus Abelmoschus, Linn. N.O. Malvacee.

Syn. - Abelmoschus moschatus, Medic.

Part used-Seeds.

Action-Aromatic, insecticide. By the Arabs the seeds are used as a Coffee flavour. In India they are 
used as adulterants for Musk and in perfumes. It is also known as an insecticide, being dusted over woollens to protect them from moths, \&c. For medicinal purposes the seeds are made into a paste with milk and employed as a remedy for itch.

Distinctive character-The seeds are reniform compressed, about $\frac{1}{8}$ inch in diameter, greyish brown, with numerous brown striæ which are concentric round the hilum. Taste, oily and musky. Odour, musky when rubbed.

MUSTARD.

Brassica nigra, Linn., Koch.

Brassica alba, Boiss.

N.O. Crucifera.

Syn. - Sinapis alba, Linn. ; Sinapis nigra, Linn., Bras. sica sinapioides, Roth.

Part used-Seeds.

Action-Irritant, stimulant, diuretic, emetic. Used chiefly as a poultice in acute local pains, pneumonia, bronchitis, and other diseases of the respiratory organs. The volatile oil is a powerful irritant, rubefacient, and vesicant, and combined with other remedies is an excellent application in rheumatic pains, colic, \&c.

The black seeds yield by distillation, after maceration with water, a volatile oil-Ol. Sinapis volatile, B.P. B.P.

Preparations-Mustard paper (leaves). Liniment

Distinctive character-Black mustard seeds are between oval and spherical, dark reddish brown, about $\frac{1}{36}$ inch in diameter and $\frac{1}{50}$ grain in weight, more or less covered with a whitish pellicle. Triturated with water they form a yellowish emulsion, emitting the acrid vapour of mustard and irritating the eyes and nose. Taste, at first bitterish, but quickly pungent. The powdered seeds are inodorous until moisture is absorbed, but the 
powder loses its power of producing pungency if long exposed to the air.

Mustard, White-The seeds are globular, yellowish, about $\frac{1}{12}$ inch in diameter, and $\frac{1}{10}$ grain in weight. The inner seed coat contains a quantity of mucilage, and hence the seeds are used to absorb the last traces of moisture in bottles which are not chemically dry, by shaking the seeds up in them. The cotyledons of the seeds contain oil, and give a pungent, but inodorous, emulsion when rubbed with water. Taste, pungent. Odour, none.

MYRRH.

Commiphora Myrrha, Holmes.

N.O. Burseracea.

Syn. - Balsamodendron Myrrha, Nees ; Commiphora Myrrha, var. Molmol, Engl.

Part used-Gum-resin.

Action-Stimulant, tonic, healing. A valuable and deservedly popular medicine. The tincture is used in inflammatory sore throat, ulcers, bad legs, thrush, and other complaints. Makes an excellent wash for ulcerated mouth, tongue, \&c. The infusion of I ounce to a pint of boiling water is taken in wineglassful doses.

Preparations-Fluid extract: Dose, 5-30 drops. Tincture B.P. and U.S.P.: Dose, $\frac{1}{2}-I$ drachm.

Distinctive character-This oleo-gum-resin occurs in various qualities, and varies in size from $\frac{3}{4}$ inch to 2 inches or more in diameter, some pieces containing gum in white streaks, and others hardly any, and some pieces more oil than others. The best for making emulsions or for use in pills are the pieces with white streaks. The oily pieces, with few streaks, are more useful for tincture. The gum left when the tincture is made with rectified spirit possesses adhesive properties, and forms an excellent mucilage for sticking purposes. 
NETTLE.

Syn.-Stinging Nettle.
Urtica diolca, Linn. N.O. Urticacee.

Parts used-Flowers, leaves, seeds.

Action-Diuretic, astringent, tonic. The herb makes a nice botanic beer, and is also used as a medicine in nettle-rash. The seeds are used in consumption. The infusion of either herb or seed of $I$ ounce to a pint of boiling water is taken in wineglassful doses.

Preparation-Fluid extract, herb : Dose, $\frac{1}{2}-1$ drachm.

Distinctive character-Stem $2 \cdot 3$ feet high, quadrangular, with opposite, stalked, heart-shaped or lanceolate-oval leaves, serrated at the margin. The flowers are small, green, and four-parted, the male flowers arranged in erect, and the female in reflexed, panicles longer than the leaf-stalks. Fruit one-seeded. When growing it is easily recognised by its yellow, creeping root, that of Urtica urens, which is only a foot high, and is usually a garden weed, being white and not creeping, and the inflorescence not so long as the leafstalks.

\section{NIGHT-BLOOMING CEREUS.}

Cereus grandiflorus, Linn. N.O. Cactacea.

Syn.-Sweetscented Cactus, Cactus grandiflorus, Miller.

Parts used-Herb, flowers.

Action-Cardiac stimulant and tonic, diuretic. It gives prompt relief in most cardiac diseases, such as palpitation, angina pectoris, cardiac neuralgia, \&c. Also useful in prostatic diseases, irritable bladder, and congested kidneys. Prof. Locke recommends it for nervous menstrual headache.

Preparation-Fluid extract (made from fresh plant) : Dose, 2-Io drops.

Distinctive character-The stem and flowers are usually sold crushed and preserved in spirit. The stems 
are, when fresh, fleshy, five to seven-angled and $\frac{1}{2}-\frac{3}{6}$ inch in diameter, and the flowers $4-5$ inches across. The calyx consists of numerous linear, hairy, orange segments, and the petals are oblong-lanceolate, white; the stamens numerous, and the stigma has many rays.

The small dried flowers of Opuntia decumana, Haw., which are of little or no use and are only about $1 \frac{1}{2}$ inch in diameter, and other species of Opuntia, are sometimes sold as Ceveus grandiflorus. A figure of the flower was published in the Pharm. Journ., Aug., r897, p. 165.

NUTMEG.

Myristica fragrans, Houtt.

N.O. Myristicacea.

Syn.-Myristica officinalis, Linn., Nux moschata.

Part used-Seeds.

Action-Carminative, stomachic. Useful in flatulency, nausea, and vomiting. Mostly employed as a flavouring for medical or culinary purposes.

Preparations - Powdered nutmegs : Dose, 5-20 grains. Fluid extract: Dose, ro-30 drops. Spirit B.P.: Dose, 5-20 drops.

Distinctive character-Nutmegs vary in size and in shape, as well as in quality, and are sold according to size. The average size runs 90-100 to the pound, and are about $\mathrm{I} t$ inch long and $\mathrm{I} \frac{3}{4}$ inch in diameter. They should be variegated with brown and white internally, and cut with an oily surface. The outside shows under a powerful lens minute, oblong or rounded, black specks. The fragrant odour is characteristic. Long nutmegs about $\mathrm{I} \frac{1}{2}$ inch long of the genuine kind are occasionally met with, and these can be distinguished from the Papua nutmegs (Myristica argentea, Warb.), which are similar in size and shape, by the absence of black specks externally, and the acrid 
taste of the latter, which otherwise resemble true nut. megs. Bombay long nutmegs also occur in commerce, but these lack fragrance and are usually 2 inches long by rather more than $\frac{3}{4}$ inch broad. Illustrations are given in the Pharm. Journ., April 3rd, Igog, p. 460.

NUX VOMICA.

Strychnos Nux Vomica, Linn.

N.O. Loganiacea.

Syn.-Quaker Buttons, Poison Nut.

Part used-Seeds.

Action-Tonic, bitter, stimulant. Used as a general tonic, mostly in combination with other remedies, for neuralgia, dyspepsia, debility, impotence, and in chronic constipation, as it increases peristalsis. Should be given with great care.

Preparations-Fluid extract B.P.: Dose, I-3 drops. Tincture B.P. and U.S.P.: Dose, 5-1 5 drops. Strychnine (Alkaloid). Solid extract B.P.: Dose, $\frac{1}{4}$-I grain.

Distinctive character-The seeds are of a light greenish grey colour, with a satiny surface due to the closely-appressed hairs. They are circular, usually rather less than $I$ inch in diameter and about $\frac{1}{4}$ inch in thickness, depressed on one side and convex on the other, and often with a keeled or sharp margin. On the convex side there is usually a raised line (raphe) proceeding from a central scar (hilum) to a small protuberance at the edge (micropyle). Internally it is very hard and horny, but when split open shows a small embryo with heart-shaped, three-veined, white cotyledons, and a straight radicle. Taste, extremely bitter. Inodorous.

Nux Vomica seeds are poisonous, but vary in the amount of the Strychnine they contain, the large seeds from Ceylon being the richest. 
Syn.-Tanner's Bark.

Part used-Bark.

Action-Slightly tonic, strongly astringent, antiseptic. Useful in chronic diarrhœa and dysentery, either alone or in conjunction with aromatics. A decoction is made from I ounce of bark in a quart of water, boiled down to a pint, and taken in wineglassful doses. Externally this forms an excellent gargle for sore and relaxed throat and a good injection for leucorrhœa.

Preparation-Fluid extract: Dose, $\frac{1}{2}-\mathrm{I}$ drachm.

Distinctive character-The bark and branches of the young tree are greyish, and more or less polished externally and brownish internally. The fracture is fibrous, and the inner surface rough, with projecting medullary rays. The taste is astringent and the odour slightly aromatic.

OATS.

Syn.-Groats.

Part used-Seeds.

Action-Nervetonic, stimulant, antispasmodic. Avena forms an important restorative in nervous prostration and exhaustion after all febrile diseases, and as a tonic in spermatorrlica, insomnia, \&c. It seems to exert a very beneficial action upon the heart muscles and on the urinary organs, speedily relieving spasmodic conditions of bladder and ureter. It is mostly used in the form of a fluid extract.

Preparation-Fluid extract: Dose, 10-30 drops.

Distinctive character-The seeds with the husk removed are sold in two or more forms. Crushed or in 
coarse powder they are known as groats, and in fine or coarse powder as oatmeal. Like all other cornmeal it should be kept dry, or it undergoes alteration and acquires a bitter taste. The starch of the oat is quite characteristic, consisting of simple and compound grains, the former always containing some spindle or lemonshaped grains, which rice starch never does.

OLIVE.

Olea Europar, Linn. N.O. Oleacea.

\section{Part used-Oil.}

Action-Emollient, nutritive, aperient. Olive Oil (or Lucca Oil, Sweet Oil, Salad Oil, Provence Oil, Virgin Oil), apart from its use in the household, is a valuable remedy in bowel diseases generally. Being pleasant to the taste, it is often substituted for Castor Oil as a children's laxative, also as a remedy in habitual constipation and lead colic. It removes intestinal worms and in large doses dispels biliary concretions. Externally it forms part of a large number of embrocations, ointments, liniments, \&c., used in bruises, burns, scalds, rheumatic and cutaneous affections. As an inunction in teething children it is invaluable, keeping the bowels regular and acting as a tonic by absorption. The dose of the oil varies from I teaspoonful to 2 tablespoonfuls. The fruit, from which the oil is expressed, is a valuable article of food in countries where the tree grows.

Distinctive character-Olive Oil is much adulterated. The purest or virgin oil, known as Provence or Virgin Oil, has usually a faint greenish tinge, and is more expensive. Ordinary Olive Oil often contains purified Cotton Seed Oil. The latter is a drying oil to a certain degree, and Olive Oil containing it usually forms a thin skin on the glass over which it has run. The taste of the oil is a good guide to purity. Anyone who compares it with the taste of a preserved olive will recognise it at once. 
ONION.

Part used-Bulb.
Allium Cepa, Linn. N.O. Liliacea.

Action-Diuretic, expectorant. Besides being used for culinary purposes, Onions often form an ingredient in domestic medication. Who has not heard of roasted Onion as a poultice for suppurating tumours or earache? The juice, made into a syrup, is beneficial as a cough medicine. Onions are macerated in Holland gin, and the resulting tincture is serviceable in gravel and dropsical affections. The large or Portugal Onion when boiled forms a useful remedy for a cold. In the spring the head of the Onion is apt to decay and should be removed.

ORANGE, BITTER.

Citrus vulgaris, Risso. N.O. Rutacea.

Syn.-Seville Orange, Bigarade Orange, Citrus Aurantium, Linn., Citrus Bigaradia, Loisel.

Part used-Fruit rind.

Action-Tonic, stomachic, carminative. Orange peel is mostly used as an agreeable flavour for bitter medicinal compounds and to allay a tendency to nausea. It can be used with nost forms of medications, especially in infusions, decoctions, tinctures, and syrups.

Preparations-Comp. tinct. of Cinchona B.P.: Dose, $\frac{1}{2}$-I drachm. Comp. tinct. of Gentian B.P.: Dose, $\frac{1}{2}-1$ drachm. Syrup B.P.: Dose, $\frac{1}{2}-I$ drachm. Tincture B.P. and U.S.P.: Dose, $\frac{1}{2}-\mathrm{I}$ drachm. Infusion of Orange B.P.: Dose, $4-8$ drachnıs. Infusion of Orange comp. B.P.: Dose, 4-8 drachms. Infusion of Gentian comp. B.P.: Dose, 4-8 drachms. Comp. spt. U.S.P.: Dose, I-2 drachms. Syrup B.P.: Dose, $\frac{1}{2}-1$ drachm. Wine B.P.: Dose, a wineglassful.

Distinctive character--The new rind is best purchased in March or April, since the new crop of fruit is 
imported in February. English-dried peel is of better quality than the imported dried peel. A fine-cut peel with very little of the white spongy parts is known as Maltese Orange Peel. The bitter orange is distinguished as the Bigaradier in trade.

ORANGE, SWEET.

Citrus Aurantium, var., dulcis, Linn. N.O. Rutacea. Syn.-Portugal Orange, China Orange, Citrus dulcis, Pers.

Parts used-Peel, flowers.

Action-Aromatic, carminative. Possesses the same properties as Bitter Orange and is used for similar purposes. Orange Water is made from the flowers by distillation and used for flavouring.

Preparations-Syrup B.P. and U.S.P.: Dose, $\frac{1}{2}-I$ drachm. Tincture U.S.P.: Dose, I drachm.

Distinctive character-The Sweet Orange Peel has less bitterness than that of the Seville Orange. The flowers of the orange are white, oblong, five-parted, with a cup-shaped calyx, and fleshy, oblong petals and numerous stamens united at the base. The unopened flowers are usually sold. They are about $\frac{3}{4}$ inch long and 1 inch broad.

ORRIS.

Iris Florentina, Linn. N.O. Iridacea.

Syn.-Florentine Orris, Orris Root.

Part used-Root. Mostly used, on account of its fragrancy, in dusting powders, toilet powders, dentifrices, cachous, \&c.

Distinctive character-The rhizome is sold in several forms. Florentine is white, irregular in shape, 
bearing small marks where the rootlets have been removed. The Verona root is usually somewhat compressed, and less suddenly tapering than the Florentine root; that from Morocco has the cortical portion not removed, and is of a dirty white colour. The Verona root is also sold trimmed for infants' use when teething. The rhizome has a violet odour.

OSIER, RED.

Cornus sericea, Linn. N.O. Cornacea.

Syn.-Rose Willow, Red Willow, Silky Cornel.

Parts used-Bark, rootbark.

Action-Astringent, bitter, tonic. Has been found of service in diarrhœa, dyspepsia, and in fevers. Is also recommended in dropsy. The infusion is useful in checking vomiting due to pregnancy or disease of the womb.

Distinctive character-Bark in thin, irregular pieces or short quills, purplish externally, somewhat warty, inner surface cinnamon-brown, even, and finely striated. Fracture even, scarcely fibrous. Taste, astringent, bitter. Odour, slight.

\section{OX-EYE DAISY.}

Chrysanthemum Leucanthemum, Linn. N.O. Composita.

Syn.-White Daisy, Field Daisy, Moon Daisy, Maudlin Daisy, Great Ox-eye, White Weed, Goldens, Horsegowan, Marguerite, Leucanthemum vulgare, Lam.

\section{Part used-Herb.}

Action-Antispasmodic, diuretic, tonic. Ox-eye Daisy has been employed successfully in whooping cough, asthma, and nervous excitability. As a tonic it 
acts similar to Chamomile, and has been recommended in nightsweats. The decoction - of usual strength-is taken in wineglassful to teacupful doses three to four times a day. Externally it is serviceable as an injection in leucorrhœa, and as a lotion for ulcers, wounds, \&c. Large doses produce emesis.

Distinctive character-The leafstem is angular, I-2 feet long, bearing stalked, serrate, spatulate leaves in the lower half, with a serrate clasping base, and serrate upper leaves, which are oblong and sessile. The yellow-centred white flowerheads have an involucre of green bracts with thin, black, membranous edges. The receptacle is hemispherical and without palex. The fruit has no pappus. Taste, bitter and tingling. Odour, faintly valerianic.

PAPAW.

Carica Papaya, Linn. N.O. Papayacea.

Syn.- Pawpaw, Melon Tree, Mamæiro, Papaya vulgaris, DC.

Parts used-Fruit juice and ferment "Papain."

Action-Digestive. "Papain," a white powder, is administered generally in all digestive disorders where albuminoid substances pass away undigested. It is generally used in combination with an alkali, such as bicarbonate of soda, and acts best in an alkaline medium. A solution of the ferment is reputed to dissolve the false membranes in diphtheria and croup, when applied frequently.

Preparation-"Papain": Dose, I-5 grains.

Distinctive character-."Papain" is a white powder soluble in glycerine, and is prepared from the juice of the Papaw tree. Another preparation of a brownish white tint and granular in character consists of the dried juice of the fruit. 
PAWPAW SEED. Asimina trilloba, Dur. N.O. Anonacea.

Distinctive character-Seeds flat, oblong-oval, with the greyish hilum at one end, brown and slightly polished, with darker brown pinnate lines on the surface, about $I$ inch long and $\frac{5}{8}=\frac{6}{8}$ inch broad and $\frac{1}{6}$ inch thick. The seed has ruminated, horny albumen, and exudes oil when pressed by the nail. Taste and odour, resinous. N.O. Aquifoliacea.

Syn.-Maté, Yerba Maté, Jesuit's Tea, Brazil Tea.

Part used.-Leaves.

Action-Stimulant, diuretic. The peculiar properties it possesses are chiefly due to Caffeine. Its action resembles such stimulants as Tea, Coffee, and Coca, although different from either. Is used largely in South America as a Tea substitute. If taken in large doses it acts as a purgative.

\section{Preparation-Fluid extract: Dose, $\frac{1}{2}-1$ drachm.}

Distinctive character-The leaves are sold in two forms. The Brazilian is sold in the form of roughly powdered leaves and stalks. The Paraguay kind, which is considered the best, consists of broken leaves only. The leaves are coriaceous in texture, but are rarely perfect enough to show their form. The characteristic features under the microscope are the thick striated cuticle, the straight-walled polygonal cells of the epidermis, and the stomata overhung by three or four contiguous cells. Taste, bitterish. Flavour, recalling those of tea, lime flowers, and orange. 
PAREIRA. Chondrodendron tomentosum, Ruiz.\& P.

Syn.-Pareira brava.

N.O. Menispermacea.

Part used-Root.

Action-Tonic, diuretic, aperient. Used as a stimulant to kidneys, relieving urinary irritation, and in chronic inflammation of bladder and various urinary diseases. The infusion of I ounce to a pint of boiling water is taken in wineglassful doses as required.

Preparation-Fluid extract B.P.: Dose, 1-2 drachms.

Distinctive character-The root occurs in tortuous woody pieces of varying length, and about I-2 inches in diameter, black externally, longitudinally furrowed, with transverse ridges and some constrictions, and internally greyish yellow or brownish. The transverse section shows three or four concentric rings, usually about 1 inch in diameter and each separated from the contiguous one by a wavy line of softer tissue. The medullary rays are broad, sometimes broader than the woody wedges. The taste is bitter and slightly sweet, but the root is inodorous. The stem, which often forms more than one-third of the imported drug, is similar in structure, but differs in the outer surface, being grey, with numerous round, warty lenticels. Substitutes often appear in the market, but all of them have narrower rings and thinner medullary rays, and in some kinds no bitterness is present, and in all except the African false Pareira the outer surface is not black. The African kind is recognisable by the narrower rings and thinner medullary rays.

PARSLEY. Carum Petroselinum, Benth \& Hook. N.O. Umbellifera. Syn.-A pium petroselinum, Linn., Petroselinum sativum, Hoffm.

Parts used-Root, seeds.

Action-A perient, diuretic, emmenagogue. Is chiefly used on account of its diuretic properties. In gravel, 
stone, congestion of kidneys, and in dropsy it will be found of great service. The seeds contain an oil which is considered a safe and efficient emmenagogue, and is used in amenorrhœa and dysmenorrhœa.

Preparations-Fluid extract, root: Dose, $\frac{1}{2}$-I drachm. Fluid extract, seeds: Dose, $\frac{1}{2}-\mathrm{I}$ drachm. Apiol (oil) : Dose, 5-I 5 drops in capsules.

\section{PARSLEY PIERT.}

Syn.-Parsley Breakstone.

Alchemilla arvensis, Scop. N.O. Rosacea.

\section{Part used-Herb.}

Action-Demulcent, diuretic. Used in all cases of gravel, kidney, and bladder complaints. It acts directly on the parts affected, and will be found exceedingly valuable even in seemingly incurable cases. Several London doctors prescribe this remedy regularly. The infusion is taken in teacupful doses three times daily.

Preparation-Fluid extract: Dose, I drachm.

Distinctive character-This small herb varies from 3.5 inches in height, has small palmate leaves below, about $\frac{1}{2}$ inch in diameter, the upper leaves being trifid and wedge-shaped at the base. The greenish flowers in axillary tufts are very small. The whole plant is hairy, with slender scattered hairs. Taste, astringent. Odour, none.

PASSION FloWER. Passiflora incarnata, Linn. N.O. Passifloracea.

Syn,-Maypops.

Parts used-Plant and leaves.

Action-Antispasmodic, sedative, narcotic. Used as a rest-producing remedy in nervous, irritative and neuralgic pains with debility, and also in nervous headache, hysteria, spasms, and convulsions.

Preparation-Fluid extract: Dose, 10.20 drops. 
Distinctive character-Patchouli leaves, as imported, are usually of dark brown colour, crumpled and often mixed with other leaves. The genuine leaves, when soaked out in water, are seen to be ovate in form; they attain to 4 inches long and $5 \frac{1}{2}$ inches broad, but younger leaves are only half that size, the margin is lobed, with irregular crenate-serrate teeth, the lobes being obtuse, and the base of the leaf not toothed. The hairs are simple and usually four-celled. Taste, aromatic. Odour, strong and persistent.

PEACH.

Prunus Persica, Stokes. N.O. Rosacee. Syn.-A mygdalus Persica, Linn., Persica vulgaris, Null. Parts used-Bark, leaves.

Action-Sedative, diuretic, expectorant. For irritation and congestion of the gastric surfaces this has been found almost a specific. It is also used in coughs, whooping cough, and chronic bronchitis. An infusion of $\frac{1}{2}$ ounce of bark or I ounce of leaves to a pint of boiling water is taken in doses from a teaspoonful to a wineglassful as required.

Distinctive character-Leaves elliptical, about 4 inches long and $\mathrm{I} \frac{1}{2}$ inch broad, tapering to a sharp point above, with a short leafstalk about $\frac{1}{2}$ inch long, the margins minutely serrate with a gland at the base on each side, replacing the lowest teeth of the leaf, under surface pale green. Bark in small, thin, pale brown fragments, rarely exceeding $1 \frac{1}{2}$ inch in length and 1 inch in thickness, having a smooth, dark brown epidermis, which readily exfoliates, and an inner surface with a faint network of fibres. Fracture short, but fibrous. Taste, bitter and very astringent. Flavour, slight. 
PELLITORY.

Anacyclus Pyrethrum, DC.

N.O. Composita.

Syn.-Pellitory Root, Spanish Pellitory, Spanish Chamomile, Anthemis Pyrethrum, Linn., Matricaria Pyrethrum, Baill.

\section{Part used-Root.}

Action-Local irritant, rubefacient. It is an excellent remedy for toothache.

Preparation-Tincture B.P. and U.S.P.: Dose, 20.30 drops.

Distinctive character-In dark brown cylindrical pieces, about 2-3 inches long and $\frac{1}{2}$ inch broad, tapering slightly to either end and often having at the crown a tuft of soft woolly hairs furrowed longitudinally, with a short fracture and a radiate structure, with dark resin cells in the bark. Taste, slowly pungent and acrid, causing a flow of saliva. Odour, characteristic.

\section{PELLITORY-OF-THE-WALL.}

Parietaria officinalis, Linn. N.O. Urticacea.

\section{Part used-Herb.}

Action-Laxative, diuretic. A most efficacious remedy in stone, gravel, dropsy, and suppression of urine. Usually combined with Wild Carrot and Parsley Piert. The infusion of $I$ ounce to a pint of boiling water is taken in wineglassful doses.

Preparation-Fluid extract: Dose, I drachm.

Distinctive character-Herb about I-2 feet high, with brittle, reddish stems, and stalked, lanceolate leaves I-2 inches long and $\frac{1}{2}-\mathrm{I}$ inch broad, with slender stalks about $\frac{3}{4}$ inch long. Flowers small green, sessile, axillary. The stems and veins of the under surface of 
the leaves are furnished with short soft hairs; the upper surface of the leaves is nearly smooth, with sunken veins. Taste, insipid. Odour, none.

PELLITORY, DALMATIAN.

Chrysanthemum cinerariafolium, Vis.

PELLITORY, PERSIAN.

Chrysanthemum roseum, Adam. Pyrethrum roseum, Bieb. N.O. Composita. Syn.-Insect Powder, Insect Flowers.

Part used-Closed flowers.

Action-Insecticide, vermin killer. Insect powder is harmless to human beings, and is used in powder, lotions, and in fumigations to destroy insects, \&c.

Distinctive character-The closed flowers are preferred as being more active. The phyllaries or bracts outside the flowers are lanceolate, acute, and hairy. The receptacle has no paleæ and is nearly flat; the marginal florets are whitish, and the fruit calyx has five slender rib-like wings, and five teeth, but no pappus. Taste, slightly acrid. Odour, none.

PENNYROYAL.

Syn.-European Pennyroyal.

\section{Part used-Herb.}

Action-Carminative, diaphoretic, stimulant, emmenagogue. It is principally used as a remedy in obstructed menstruation, for which it forms a reliable cure, especially where a sudden chill or cold is the cause. It may also be employed with advantage in cases of spasms, hysteria, flatulence, and sickness, as it is very 
warming and grateful to the stomach. The infusion of I ounce of herb to a pint of boiling water is taken warm in teacupful doses, frequently repeated.

Preparations-Fluid extract: Dose, $1-1$ drachm. Essence : Dose, 5-20 drops. Oil: Dose, $\frac{1}{2}-3$ drops.

Distinctive character-Herb 8-I2 inches high. Stems bluntly quadrangular. Leaves opposite, shortly stalked, oblong-oval, obtuse, about I-I $\frac{1}{2}$ inch long and $\frac{1}{2}$ inch broad, faintly serrate, nearly smooth, or hairy. Taste and odour, mint-like, but characteristic.

\section{PEONY.}

Pronia officinalis, Linn. N.O. Ranunculacea.

Syn.-Pæonia, Common Peony, Piney.

Part used-Root.

Action-Antispasmodic, tonic. Successfully employed in convulsive and spasmodic nervous affections such as chorea, epilepsy, spasms, \&c. The infusion of I ounce powdered root in a pint of boiling water is taken in wineglassful to teacupful doses three to four times daily.

Distinctive character-In scraped, spindle-shaped pieces, averaging 3 inches long and $\frac{1}{2}-\frac{3}{4}$ inch in diameter, pinkish grey or dirty white, strongly furrowed, and shrunken longitudinally. The transverse section is starchy, radiate, with the medullary rays more or less tinged with purple. Taste, sweet then bitter. Inodorous.

\section{PEPPER.}

Syn.-Black Pepper.

Part used-Unripe berries.

Action-Carminative, stimulant. Besides its use as a condiment, Pepper is a valuable gastro-intestinal stimulant, of great service in flatulence, congestive chills, and indigestion. It has been recommended in intermittent fevers, and forms an ingredient in "Asiatic 
Pills." The powdered Peppercorns may be taken in doses of 3-I 5 grains.

Preparations-Confection of Pepper B.P.: Dose, I-2 drachms. Oleoresin U.S.P.: Dose, $\frac{1}{2}$ grain.

Distinctive character-Black pepper is the dried, unripe fruit, externally black and wrinkled, $\frac{1}{5}$ inch in diameter, spherical, containing only one seed which is horny and grey and starchy internally. Taste, very pungent. Odour, characteristic.

\section{PEPPERMINT.}

Syn.-Brandy Mint.

Part used-Herb.

Action-Stimulant, stomachic, carminative. Used for allaying nausea, flatulence, sickness, vomiting, and as an infants' cordial. Generally combined with other medicines when its stomachic effects are required. The infusion of I ounce to a pint of boiling water is taken in wineglassful doses. Menthol is obtained from Peppermint Oil by subjecting it to a very low temperature.

Preparations-Fluid extract: Dose, 1 -I drachm. Oil: Dose, $\frac{1}{2}-3$ drops. Spirit B.P.: Dose, 5-20 drops. Water B.P. and U.S.P.: Dose, 4 drachms.

Distinctive character-Stem usually purplish, 2-4 feet high, quadrangular, leaves stalked, $2-3$ inches long and $\frac{3}{4}-1 \frac{1}{2}$ inch broad, serrate, slightly but not visibly hairy. Taste and odour, characteristic.

\section{PERIWINKLE.}

Syn.-Greater Periwinkle.

Part used-Herb.
Vlnca major, Linn. N.O. Apocynacea.

Action-Astringent, tonic. It is reputed to be useful in menorrhagia and hæmorrhages generally.

Distinctive character-Stems cylindrical, smooth, leaves opposite, shining at intervals of 2.3 inches, 
stalked, ovate, entire at the margins, $1 \frac{1}{2}-3$ inches long and I-2 inches broad, the lower leaves largest. Taste, bitterish, slightly acrid. Odour, none.

\section{PERUVIAN BALSAM.}

Myroxylon Pereira, Klotsch. N.O. Leguminosa.

Syn.-Balsam of Peru, Toluifera Pereira, Baill.

Part used-Balsam.

Action-Stimulating, expectorant. Useful in all chronic mucous affections, catarrh, gonorrhœea, leu. corrhœa, diarrhœea, dysentery. Externally used in ulcers, wounds, ringworm, eczema, and other cutaneous affections. Dose, 10-30 drops.

Distinctive character-A black oily fluid of sp. gr. $I \cdot I 5 \cdot I \cdot I 6$, and a sweet balsamic odour. The balsam is liable to adulteration, but tests to ascertain its purity are given in the British Pharmacopœia.

PERUVIAN BARK.

Cinchona succirubra, Pav. N.O. Rubiacea.

Syn.-Cinchona Bark, Red Bark.

Part used-Bark.

Action-Antiperiodic, febrifuge, tonic, astringent. Useful in all febrile and typhoid conditions, and in remittent and intermittent fevers. As a general tonic it is much esteemed, and finds extensive use in the treatment of neuralgia, dyspepsia, and debility. With 
many persons overdoses produce headache, giddiness, and imperfect hearing.

Preparations-Powdered bark: Dose, 10-60 grains. Fluid extract B.P.: Dose, 15.60 drops. Fluid extract (alc.): Dose, $\frac{1}{2}-I$ drachm. Tincture B.P.: Dose, $\frac{1}{2}-I$ drachm. Tincture comp. B.P.: Dose, $\frac{1}{2}$-I drachm. (Alkaloids) Quinine: Dose, I-Io grains. Cinchonine: Dose, I-Io grains. Cinchonidine : Dose, I-Io grains. Acid infusion B.P.: Dose, $\frac{1}{2}-I$ ounce.

Distinctive character-The bark is usually in quilled pieces about $3-I$ inch in diameter. The outer surface is often shrivelled longitudinally, and marked with numerous round lenticels. Fracture red-brown, shortly fibrous. Transverse cracks when present are not rough to the touch. Taste, astringent and bitter. Odour, slight.

PICHI.

Fabiana imbricata, Ruiz. and Pavon.

N.O. Solanacee.

Parts used-Leaves, twigs.

Action-Diuretic, tonic, hepatic, stimulant. It favourably influences digestion in dyspepsia and jaundice, acting upon the stomach and liver. As a diuretic it is of value in catarrhal and functional diseases of the kidneys. The infusion of $\mathrm{I}$ ounce in a pint of boiling water is taken in wineglassful doses every four hours.

Preparation-Fluid extract: Dose, $\frac{1}{2}-\mathrm{I}$ drachm.

Distinctive character-The drug consists of stems irregularly branched, with erect twigs covered with closely-imbricated, heath-like leaves, which are fleshy, obtuse, and keeled with a prominent midrib beneath. The stem bears short glandular hairs and is marked with spirally-arranged paler scars where the twigs have fallen. Flowers, when present, white, tubular, constricted at the throat. Taste, bitterish. Odour, faint but agreeable. 
PILEWORT.

Ranunculus Ficaria, Linn.

N.O. Ranunculacea.

Syn.-Small Celandine, Lesser Celandine.

Part used-Herb.

Action-Astringent. As its name denotes it is chiefly used for piles, for which it is almost a specific. Internally the infusion of $I$ ounce in a pint of boiling water is taken in wineglassful doses. Generally this is sufficient to cure most cases. Externally it can be used with advantage as an ointment; applied locally night and morning.

Distinctive character-Leaves mostly radical, with stalks $4-5$ inches long, the blade $I-I \frac{1}{2}$ inch long and $I \frac{1}{2}-2$ inches broad, broadly cordate-angular, one to three only on a stem. Flowers solitary, stalked, buttercup-like, about I inch in diameter, petals yellow, usually eight, sepals three. Root of several fleshy knobs, oblongrounded or club-shaped, $\frac{1}{4}-1$ inch long, $\frac{1}{8}$ inch broad. Taste, acrid. Odour, none.

PIMPERNEL, SCARLET. Anagallis arvensis, Linn. N.O. Primulacee.

Syn.-Red Pimpernel, Shepherd's Barometer, Poor Man's Weatherglass.

\section{Part used-Leaves.}

Action-Diuretic, diaphoretic, expectorant. This plant possesses very active properties, although its virtues are not fully known. For this reason caution should be exercised in its use for dropsy, rheumatic affections, hepatic and renal complaints. The fresh leaves are made into a tincture-Io ounces to a pint of diluted alcohol-the dose of which is from I-5 drops. 
The powder of the dried leaves is given in 15.60 grain doses.

Distinctive character-Stem weak, procumbent or ascending, leaves opposite, about $\frac{1}{2}$ inch long and $\frac{8}{8}$ inch broad, ovate, sessile, with entire margins, and black dots on the under surface. Flowers scarlet, corolla rotate. Fruit one-celled and globular, splitting open horizontally. Taste, acrid, mucilaginous. Said to be poisonous.

PINE.

Pinus species.

N.O. Pinacea.

Syn.-Pinus sylvestris, Linn.: Scotch Pine, Scotch Fir. Pinus palustris, Mill., Pimus australis, Michx: Broom Pine, Swamp Pine, Yellow Pitch Pine. Pinus Tada, Linn.: Old Field Pine. Pinus Punilio, Haenke., is the source of the B.P. Oil of Pine-Ol. Pini.

Parts used-Oil (Ol. Terebinthinæ), resin (Thus Americanum).

Action-Rubefacient, irritant, diuretic. Adminstered internally it acts upon the urinary apparatus and is valued as a remedy in chronic affections of the kidneys and bladder, gonorrhœe, gleet, and diseases of the mucous membranes of the respiratory organs. Externally the drug is an excellent detergent for old ulcers, wounds, tumours, abscesses, and boils. As a stimulant for external use, various forms, such as ointments, plasters, liniments, \&c., may be used. The dose of Turpentine (resin) is from Io-6o grains.

Preparations-Oil of Turpentine, Spirits of Turpentine B.P.: 2-10 drops. As a vermifuge, 2-4 drachms. Tar B.P. (P. sylv.). Tar U.S.P. (P. palust.). Ointment Tar B.P. Ointment Resin B.P. Syrup Tar U.S.P.: Dose, I drachm.

Distinctive character-Flowering buds, $\frac{1}{2}-\frac{1}{2}$ inch long, about 1 inch in diameter, solitary or in clusters of 
five or more, composed of pale brown, polished scales, with fringed membranous margins, the outer scales often agglutinated with exuded turpentine.

American crude turpentine, dried on the tree, is known as American frankincense. It has a turpentiny odour quite different from true frankincense, which more approaches the lemon in odour. Resin is sold in different grades and degrees of hardness. The hard, dry, black resin is used in powder for wounds by surgeons in the army or navy. If resin containing traces of oil be used, the powder runs together in the tropics and becomes useless. For technical purposes such as for inserting knife handles, \&c., resin containing a little turpentine is tougher and not so friable. For making varnish, the varieties known as water-white, or the palest amber, resin is preferred. For medicinal purposes the opaque yellow resin containing a little water is generally used.

PINE, WHITE.

\section{Part used-Bark.}

Action-Expectorant, diuretic, demulcent. Owing to its balsamic properties it is used for the relief of coughs, colds, and chest diseases generally. It seems also to exert a favourable influence upon the urinary apparatus. The compound syrup is the popular form of administration, and is made from Wild Cherry, Bloodroot, Balm of Gilead, \&c.

\section{Preparation-Fluid extract: Dose, $\frac{1}{2}-1$ drachm.}

Distinctive character-The inner bark, which is the part used, occurs in pieces about in inch thick, 2 or more inches in width and 5 or 6 inches long, of a bright buff colour on the inner surface, smooth and finely striated, having on the outer surface numerous scattered, small, round oil receptacles. Fracture pale buff, tough, with short fibrous layers. Taste, mucilaginous, astringent. Odour, slight. 
PINKROOT.

Splgelia Marilandica, Linn. N.O. Loganiacea.

Syn.-Wormgrass, Carolina-pink, Maryland-pink, Indian Pink.

Parts used-Whole Plant, Root.

Action-In general use in U.S.A. as a vermifuge for children and adults, and considered a certain and powerful remedy. For children an infusion ( $\mathrm{r}$ ounce to a pint) is given, sweetened, in tablespoonful doses morning and evening. The dose should be increased according to age, that for an adult being a teacupful. Its effects are more certain if a purgative, such as Senna, is added.

Preparations-Powdered plant or root for children, four years old, Io to 20 grains; adults, I to 2 drachms, repeated for a few days morning and evening. Fluid extract: 1-I drachm.

Distinctive character-The whole herb is usually sold in this country under the name of Indian Pinkroot and is preferable, because it is easier to distinguish the root with the herb attached than the root alone, which is sometimes adulterated. The rhizome somewhat resembles that of serpentary, but is darker in colour and is not aromatic. It is about $\frac{2}{10}$ inch in diameter, with cup-shaped scars on the upper surface and numerous rootlets below. The large cells of the middle bark of the roots show fine spiral markings.

PINUS BARK.

Tsuga Canadensis, Carr. N.O. Pinacea.

Syn.-Hemlock Spruce, Hemlock Bark, Pinus Canadensis, Linn., Abies Canadensis, Michx.

Part used-Bark.

Action-Astringent, tonic. Used as an astringent injection in female complaints, such as leucorrhœea, falling of the womb, \&c., in the shape of an infusion of 
2 ounces of crushed bark to a pint of water, or the fluid extract may be diluted with four times its weight of water and so used. The bark forms an ingredient in Composition Powder.

Preparation-Fluid extract: Dose, 玄-I drachm.

Distinctive character-The bark occurs in small pieces $I$ inch or more long and $\frac{1}{2}-I$ inch broad and $\frac{1}{4}$ inch thick, with a madder-red outer corky layer, and an inner fibrous layer. Fracture rough, shortly fibrous, showing groups of whitish stone cells. Taste, astringent, slightly turpentiny. Odour, slightly terebinthinate.

\section{PIPSISSIWA.}

Syn.-Prince's Pine, Ground Holly.

\section{Part used-Leaves.}

Action-Astringent, alterative, diuretic, tonic. Its alterative properties make it very useful in long-standing rheumatic and kidney affections. It is especially valuable in scrofulous debility. The infusion of $I$ ounce in a pint of boiling water is taken in doses of a wineglassful to a teacupful as required.

Preparations-Fluid extract: Dose, $\frac{1}{2}$-I drachm. Chimaphilin: Dose, I-3 grains.

Distinctive character-Leaves leathery, oblanceolate, with a rounded apex, about $\mathrm{I}+1$ inch long and $\frac{3}{8} \mathrm{inch}$ broad, distantly serrate, except towards the base, upper surface minutely wrinkled, paler beneath, usually mixed with slender, reddish brown, woody stems.

PITCHER PLANT.

Sarracenia purpurea, Linn.

N.O. Sarraceniacea.

Syn.-Fly Trap, Water Cup, Saddleplant.

Parts used-Root, leaves.

Action-Stomachic, diuretic, laxative. Useful in derangements of stomach, liver, and kidneys, such as 
constipation, dyspepsia, menstrual complaints, \&c. An infusion of $\mathrm{I}$ ounce to a pint of water is taken in doses of a tablespoonful to a wineglassful as may be required. Has lately achieved a great reputation as a prophylactic against and a cure for small-pox.

Preparations-Powdered root: Dose, 10-30 grains. Fluid extract: Dose, $\frac{1}{2}-\mathrm{I}$ drachm.

Distinctive character-The pitchers are 6-8 inches or more long, and are formed from the leafstalks and stipules, the latter forming a sharp wing on the inner side, the leafblade forming a roundish, heart-shaped hood. The taste is bitter and somewhat astringent. Odour, none.

PLANTAIN.

Plantago major, Linn. N.O. Plantaginacea.

Syn.-Ripple Grass, Waybread.

Part used-Leaves.

Action-Cooling, alterative, diuretic. The fresh leaves rubbed on parts of body stung by insects, nettles, \&c., will afford relief and will stay bleeding of minor wounds. Useful in diarrhœa, piles, \&c. The infusion of I ounce to a pint of boiling water is taken in wineglassful doses.

Preparation-Fluid extract: Dose, $\frac{1}{2}-1$ drachm.

Distinctive character-Leaves ovate, blunt, abruptly contracted at the base, with a long, broad-channelled petiole. The blade is $4-8$ inches long and 3.6 inches broad, with five to eleven strong fibrous ribs; the margin is sometimes entire and sometimes coarsely and unequally dentate-serrate. The inflorescence is a dense spike of four-parted flowers, with purple anthers and about two to four seeds in each cell of the fruit. Taste, astringent. Odour, none. 
PLEURISY ROOT.

Asclepias tuberosa, Linn.

N.O. Asclepiadacea.

Syn.-Butterfly Weed, Swallowwort, Wind Root, Tuber Root.

Part used-Root.

Action-Antispasmodic, diaphoretic, expectorant, tonic. Is also mildly cathartic and carminative. As its name implies, it is of great use in pleurisy, in which disease it mitigates the pain and relieves the difficulty of breathing. It is valuable in all chest complaints and possesses a specific action on the lungs, assisting expectoration, subduing inflammation, and exerting a general mild tonic effect on the system. Recommended especially in pulmonic catarrh. A very useful medicine may be made as follows: Essence of Composition Powder, I ounce ; Fluid extract Pleurisy Root, I ounce; mix and take a teaspoonful three or four times daily in warm sweetened water.

Preparations-Fluid extract : Dose, $\frac{1}{2}-I$ drachm. Asclepin: Dose, I-4 grains. The diaphoretic action may be obtained by taking a teacupful of warm infusion ( $I$ in 30 ) every hour.

Distinctive character-Rootstock with a knotty crown, slightly annulate. Root longitudinally wrinkled, buff brown externally, whitish internally. Fracture uneven, tough, that of the bark short, brittle. Taste, bitterish, somewhat acrid.

POISON OAK (Poison). Rhus Toxicodendron, Linn. N.O. Anacardiacea.

Syn.-Poison Ivy, Poison Vine.

Part used-Leaves.

Action-Stimulant, narcotic, irritant. Has been used with success in treatment of obstinate skin diseases, 
and is, in small doses, an excellent sedative to the nervous system. Valuable in acute rheumatism, articular stiffness, \&c.

Preparation-Fluid extract: Dose, 5-30 drops.

Distinctive character-Leaves trifoliate, the terminal leaflet with a longer stalk, the lateral nearly sessile, about 4 inches long, obliquely ovate, entire or sometimes notched, downy beneath, papery and brittle when dry, sometimes with black spots of exuded juice, turned black on drying. Taste, acrid, somewhat astringent. Odour, none.

POKE ROOT.

Phytolacca decandra, Linn. N.O. Phytolaccacea.

Syn.-Pigeon Berry, Garget.

Parts used-Root, berries.

Action-Emetic, cathartic, alterative. Poke Root is considered a valuable remedy in dyspepsia, but is mostly used in syphilitic and chronic rheumatism. It also finds use in the treatment of ulcers, ringworm, scabies, granular conjunctivitis, and dysmenorrhœa. The berries are milder in action.

Preparations-Fluid extract, berries: Dose, $\frac{1}{2}-1$ drachm. Fluid extract, root: Dose, $\frac{1}{t}-\frac{1}{2}$ drachm. Phytolaccin : Dose, I-3 grains.

Distinctive character-The root is usually sold in transverse slices, or in pieces split longitudinally, but in either case the characteristic concentric rings are easily seen. The outer surface is brownish grey and wrinkled. The inner whitish and hard, but not woody. Fracture fibrous. Taste, sweetish and acrid. Inodorous. The berries are depressed-globular, purplish black and fleshy, about $\frac{1}{8}$ inch in diameter and composed of ro carpels, each containing one lens-shaped seed. Taste, sweetish. Inodorous. 
POLYPODY ROOT.

Polypodium vulgare, Linn.

N.O. Filices.

Syn.-Rock Polypody, Brake Root, Rockbrake.

Parts used-Root, leaves.

Action-Alterative, tonic, pectoral, expectorant. It is much used in coughs, consumption, and chest diseases, for which complaints it is considered highly valuable. As a tonic in dyspepsia and loss of appetite, and as an alterative in skin diseases it will be found certain and safe. Its action is peculiar in that it occasionally produces a rash of red spots, but this disappears in a short time and causes no inconvenience. The infusion of $\frac{1}{2}$ ounce of crushed root to a pint of boiling water and sweetened is taken in teacupful doses frequently.

Preparation-Fluid extract, root: Dose, I drachm.

Distinctive character-The slender rhizome, about $\frac{1}{8}$ inch in diameter and 2-3 inches long, is dark brown externally and striated longitudinally, knotty, with cupshaped leaf bases on the upper side at intervals of about 1 inch, the rootlets of the under surface being usually removed. Transverse section horny, greenish, or brown if old, with an irregular circle of minute woody plates near the circumference. Taste, very sweet, faintly acrid. Odour, none.

POMEGRANATE.

Punica Granatum, Linn.

N.O. Myrtacea.

Parts used-Root, rootbark, fruit.

Action-Tænifuge. This is one of the oldest of drugs, and is considered a specific for removal of tapeworm. It is mostly administered in a decoction prepared as follows : 8 ounces of coarse bark of the root is put into a vessel and 3 pints of cold water poured upon it. Boil for I hour, strain, and boil down until it measures 
a pint. After preparing the patient, give the decoction in doses of 4 ounces (teacupful), followed by a purgative. If necessary repeat in four hours.

Preparations-Pomegranate fruitbark: Dose, I-2 drachns. Fluid extract, rootbark: Dose, 1-2 drachms. Alkaloid Pelletierine: Dose, 5-20 grains. Decoction B.P.: Dose, $\frac{1}{2}-2$ ounces.

Distinctive character-The bark in commerce is chiefly that of the stem. It occurs in pieces 3.4 inches long, flat or slightly quilled. In the root the outer surface is yellowish grey, often furrowed, with bands of cork sometimes united to form broad flat scales. The inner surface is smooth or finely striated, greyish yellow, and has often strips of the tough whitish wood attached to it. The stem bark is usually less corky, and has traces of lichens upon it. Fracture short and granular. Taste, astringent. Odour, none.

The rind of the fruit is usually in irregular concave fragments, $\frac{1}{20}-\frac{1}{10}$ inch thick, brownish red externally, and dull yellowish on the inner surface, with depressions left by the seeds. The toothed tubular calyx is present on some of the pieces. Taste, astringent. Odour, none.

POPLAR.

Populus tremuloides, Michx. N.O. Salicacere.

Syn.-Quaking Aspen, White Poplar.

Part used-Bark.

Action-Tonic, diuretic, stimulant. This remedy deservedly holds a high position as a universal tonic. It takes the place of Peruvian Bark and Quinine, and has none of the drawbacks which interfere with the continued administration of the last-named drug. For all cases of debility, indigestion, faintness, hysteria, \&c., it may be freely given. It is also used in gonorrhœa, 
gleet, and other urinary complaints. The powdered bark is generally given in combination with other remedies.

Preparations-Fluid extract: Dose, I drachm. Populin: Dose, I-4 grains.

Distinctive character-The bark occurs in curved or flattened pieces about $I \frac{1}{2}$ inch or more in width and about $\frac{1}{1}$ inch in thickness, with the greyish epidermis removed, leaving a dull brown surface, or where it has been cut more deeply, alternate layers of buff and white tissue. The inner surface is smooth and brownish white. The transverse fracture is whitish and granular, with two or three layers of pale brownish stone cells, the inner portion showing fibrous laminæ. Taste, bitter. Odour, none. The Populus alba is used in Italy.

POPPY.

Syn.-Mawseed.
Papaver somniferum, Linn. N.O. Papaveracea.

\section{Parts used-Capsules, flowers.}

Action-Anodyne, narcotic. The crushed capsules are used generally as a poultice in combination with Chamomile Flowers. Syrups are prepared from the flowers or capsules, which are prescribed as ingredients in cough medicines. Opium is extracted from Poppies grown in the East, but those of European growth yield but little of the drug.

Preparations-Syrup of Poppy B.P., 1885. Syrup Papav. alb. (capsules): Dose, I-2 drachms.

Distinctive character-The capsules of the opium poppy are usually hemispherical, but depressed at the top, where the many-rayed stigma occupies the centre, and have a swollen ring below, where it joins the stalk. The small kidney-shaped seeds are attached to lateral 
projections (placentæ) from the inner walls of the capsule. Ovoid capsules are sometimes met with. The broken capsules and the broken fruits are sold at a cheaper price for making fomentations. The grey seeds are sold for birds' food under the name of "maw" seed. The flowers vary in colour from pure white to reddish purple. In the wild plant they are pale lilac with a urple basal spot.

POPPY, RED.

Papaver Rhoeas, Linn. N.O. Papaveracea.

Syn.-Corn Poppy, Corn Rose, Flores Rhœados.

Part used-Flower petals.

Action-Anodyne, expectorant. The fresh petals are used in B.P. 1885 for preparing a syrup (Syr. Rhœados). The dose is given as I drachm occasionally.

Distinctive character-There are several varieties of the Red Poppy, differing in the character of the fruit, which may be nearly cylindrical or globular, smooth or furnished with stiff hairs, and in the size of the lobes of the leaves. The Red Poppy, with petals having a dark spot at the base (probably a hybrid with Papaver umbrosum), makes the deepest-coloured syrup.

PRICKLY ASH. Xanthoxylum Americanum, Mill. N.O. Rutacea.

Syn.-Fagara Clava-Herculis, Toothache Tree, Yellow Wood, Suterberry, Xanthoxylum fraxineum, Willd., $X$. Carolinianum, Lamb.

Parts used-Berries, bark.

Action-Stimulant, alterative, tonic, diaphoretic. The berries are considered the more active, and are also carminative and antispasmodic. May be used wherever 
a general stimulant is required, and will be found of especial service in the treatment of rheumatism and skin diseases.

Preparations-Fluid extract, bark: Dose, $\frac{1}{2}-\mathrm{I}$ drachm. Solid extract: Dose, $2-4$ grains. Fluid extract, berries : Dose, 10-30 drops. Xanthoxylin: Dose, I-2 grains.

Distinctive character-The Northern bark is in curved or quilled fragments about $\frac{1}{24}$ inch thick, externally brownish grey, with whitish patches, faintly furrowed, with some linear-based two-edged spines about $\frac{1}{4}$ inch long. Fracture short, green in the outer, and yellow in the inner part. Taste, bitterish and very pungent, causing salivation. The Southern bark, which is usually sold, is $\frac{1}{12}$ inch thick and has conical, corky spines sometimes $\frac{4}{6}$ inch in height.

\section{PRIMROSE.}

Parts used-Root, herb.
Primula vulgaris, Huds. N.O. Primulacea.

Action-Astringent, antispasmodic, vermifuge. In the early days of medicine this plant constituted an important remedy in muscular rheumatism, paralysis, and gout. Now it is seldom used. In America, Prof. Scudder used a tincture of the fresh plant in bloom, in a strength of ro ounces to a pint of alcohol, in doses of I-Io drops, in extreme sensitiveness, restlessness, and insomnia. The infusion of root is taken in tablespoonful doses.

Distinctive character-The leaves are about 5 inches long and I inch broad, tapering, oblanceolate, rounded above, and tapering below into a winged stalk, reticulated and smooth above, the veins and veinlets prominent beneath and hairy, the margin irregularly and shortly dentate. Taste, insipid. Odour, none. Rootstock knotty, with successive bases of fallen leaves with cylindrical branched rootlets on all sides. Transverse section reddish, with a central pith. 
Syn.-Plum Tree, Prune Tree.

Part used-Dried fruits.

Action-Laxative, refrigerant. Prunes are often added to cathartic decoctions, improving their flavour and promoting their effect. In leucorrhœa, irregular menstruation, and in debility following miscarriage, the following has been used: Small Raisins or Currants, 2 ounces; Aniseed, Mace, and Cinnamon, of each $\frac{1}{2}$ ounce; and I Nutmeg powdered. Prune brandy, I quart. Powder the drugs and macerate in brandy for 2 weeks. One tablespoonful of the clear tincture is the dose, repeated thrice daily.

Prunes form a part of Confection of Sennæ B.P. and U.S.P.

PUFF BALL.

Lycoperdon Bovista, Linn.

N.O. Fungi.

Syn.-Lycoperdon giganteum, Huss.

Part used-Lower spongy portion.

Action-Hœmostatic. (The smoke produced by burning it is used for stupefying bees.)

Distinctive character-This fungus forms a globose or depressed ball, varying from 4 inches to I foot or more in diameter, sometimes furrowed at the base, whitish when young, the internal mass white, consisting of spores and fine thread-like fibres (capillitium) which, from yellow, change to brownish olive or blackish, and are discharged by the bursting of the skin. 

N.O. Ranunculacea.

Syn.-Pasque Flower, Passe Flower, Wind Flower. Meadow Anemone, Easter Flower.

Part used-Herb.

Action-Nervine, antispasmodic, alterative. Much esteemed as a remedy for nerve exhaustion in women, especially when due to menstrual troubles. Its stimulating action on all mucous surfaces makes it valuable in catarrh, amenorrhœa, \&c.

Preparation-Fluid extract: Dose, 5-10 drops.

Distinctive character-Leaves hairy, 3-5 inches long or more, and 2-3 inches broad, bipinnate, the leaflets opposite, stalked below, the segments trifid and linear, with acute points. Leafstalks round, with a narrow channel on the upper surface and purplish at the base. Flowers large, with purple sepals, hairy outside, and hairy tailed carpels. Taste, when fresh, acrid and burning. Odour, none.

In the Anemone pratensis, Linn., the flowers are smaller, blackish purple, with the tips of the segments bent backwards. This species is used in homøopathic medicine.

\section{PUMPKIN.}

Syn.-Pumpkin Seed.

\section{Part used-Seeds.}

Action-Tænicide, diuretic, demulcent. It has long been a popular worm remedy. Lately it has also been used for tapeworm. The patient fasts for a day, and takes a saline cathartic. Then a mixture-made as follows: 2 ounces of seeds are beaten up with as much 
sugar and milk or water added to make a pint-is given in three doses every two hours, and a few hours after the last dose, a dose of Castor Oil is given. The ordinary infusion-I ounce to a pint-has also been used in urinary complaints, scalding of urine, and gonorrhœa.

Distinctive character-The seeds are broadly ovate, nearly I inch long, whitish, with a shallow groove and flat ridge around the margin. The hilum is near the pointed end. Cotyledons flat, white, oily, with a short, conical radicle. Taste, nutty. Inodorous.

QUASSIA.

Picraena excelsa, Lindl.

N.O. Simarubacea.

Syn.-Bitter Wood, Bitter Ash, Quassia amava, Linn.

Part used-Wood.

Action-Tonic, bitter, anthelmintic. The wood is generally sold in small chips, but cups turned out of the log may be obtained. They are sold as Bitter Cups, and water standing in them for a short time acquires the bitterness of the wood. It is especially useful in the treatment of dyspepsia and debility of the digestive apparatus. For worms it is also a valuable remedy. The infusion of I ounce of chips in a pint of cold water is taken in wineglassful doses.

Preparations-Fluid extract: Dose, I5-30 drops. Tincture B.P. and U.S.P.: Dose, $\frac{1}{2}-\mathrm{I}$ drachm. Powd. extract U.S.P.: Dose, I grain. Conc. solut. B.P.: Dose, $\frac{1}{2}$ drachm. Solid extract: Dose, $\frac{1}{2}-2$ grains.

Distinctive character-The wood is usually sold in yellowish white chips about I inch wide, and I-4 inches long, and $\frac{1}{8}-\frac{1}{12}$ inch thick. Taste, very bitter. Odour, none. Some samples of a yellowish colour contain starch, and the infusion made with boiling water would then not keep well. These are possibly derived from Quassia amara or Surinam Quassia, which differs in con- 
taining no raphides, and in the medullary rays being only two cells broad, whilst there are usually three in the genuine or Jamaica Quassia. Exhausted Quassia having hardly any bitterness is sometimes met with in commerce, and also Quassia with greyish markings due to fungus, and therefore not fit for infusion.

\section{QUEBRACHO.}

Aspidosperma Quebracho-blanco, Schlecht.

Part used-Bark.

N.O. Bignoniacea.

Action-Antiperiodic, tonic, ant-asthmatic. Very useful in the suffocating symptoms of bronchitis, asthma, \&c. Also recommended in pulmonary complaints.

Preparations-Fluid extract: Dose $\frac{1}{2}-\frac{1}{2}$ drachm. Aspidospermin (Alkaloid).

Distinctive character-The bark occurs in curved or flattish pieces $\frac{1}{2}-\mathrm{r}$ inch thick, greyish and deeply fissured externally. The inner surface is yellowish brown, often with a reddish tint and striated. The transverse fracture shows a coarsely granular, yellowish brown outer layer, and a shortly fibrous or splintery, darker inner layer. Taste, bitter. Odour, none.

\section{QUEEN'S DELIOHT. Stillingia sylvatica, Linn.}

N.O. Euphorbiacea.

Syn.-Queen's Root, Yaw Root.

Part used-Root.

Action-Alterative, laxative, tonic, diuretic. This is principally used in cases of syphilis, scrofula, and impure conditions of the blood, for which it forms a 
certain and valuable remedy. It is generally given in combination with other medicines.

Preparations-Powdered root: Dose, 6-1o grains. Solid extract: Dose, 2-5 grains. Fluid extract: Dose, ro-30 drops. Tincture: Dose, $\frac{1}{2}-2$ drachms. Stillingin : Dose, I-3 grains.

Distinctive character-In pieces several inches in length and from $\frac{3}{4}-2$ inches thick, tapering, greyish brown, wrinkled longitudinally. Bark thick and, as well as the central wood, pinkish white, with numerous minute resin cells, tough and finely fibrous, and often starchy. . Taste, bitter and acrid and pungent. Odour, characteristic and unpleasant:

QUINCE.

Pyrus Cydonia, Linn. N.O. Rosacea.

Syn.-Quince seed, Cydonia vulgaris, Pers.

Part used-Seeds.

Action-Mucilaginous, demulcent. It is of use in gonorrhœa, dysentery, and diarrhœa; externally also, in eye diseases, as a soothing lotion.

Distinctive character-The seeds or pips are usually glued together in a double row of three to fourteen by the dried mucilage, contained in the outer seed coats. In appearance, size, and taste they resemble apple pips, but have become angular by mutual pressure.

RAGWORT.

Senecio Jacobra, Linn. N.O. Composite.

Syn.-Stinking Nanny, St. James' Wort, Staggerwort, Ragweed, Dog Standard.

Part used-Herb.

Action-Diaphoretic, detergent. Useful in coughs, colds, influenza, and catarrh of mucous membranes 
generally. It gives relief to sciatica and rheumatic or gouty pains in limbs. The decoction of $I$ ounce in a pint of water is taken in wineglassful doses as required. Externally this is used as an application to ulcers, wounds, \&c., and as a gargle in relaxed throat. A poultice may be made from the herb and applied to gouty swellings of joints.

Preparation-Fluid extract: Dose, $\frac{1}{2}$-I drachm.

Distinctive character-Stem striate, $\mathrm{I} \frac{1}{2}-2$ or 3 feet high, leaves alternate, lower lyrate-pinnatifid, stalked, upper sessile, bi-pinnatifid, with oblong segments deeply and irregularly toothed. Flowerheads yellow. Florets of the ray smooth, with deciduous pappus. Florets of the disk hairy.

RASPBERRY.

Syn.-Rubus strigosus, Michx.

Parts used-Leaves, fruits.

Action-Astringent, stimulant. The infusion of $I$ ounce in a pint of boiling water is used as a general gargle in sore mouths, canker of the throat, \&c., and as a wash for ulcers and wounds. Combined with Slippery Elm the leaves form a good poultice for removing proud flesh and cleansing wounds. It will be found valuable in stomach complaints of children. Dr. Thomson and Dr. Coffin recommend the drinking of the tea by pregnant females for giving strength and rendering parturition easy and speedy. It should be taken freely before and during the confinement. The addition of Composition Essence will form a valuable adjunct at such times. This should always be taken warm.

Preparation-Fluid extract: Dose, I-2 drachms.

Distinctive character-Leaves stalked, pinnate, with two pairs of ovate leaflets, and a larger terminal 
one, the leaflets doubly serrate at the margins, rounded at the base, and abruptly pointed at the apex, and greyish white beneath, with appressed felted hairs, $2 \frac{1}{2}-3 \frac{1}{2}$ inches long and 2-3 inches broad. Taste, astringent. Odour, none.

RED CLOVER.

Trifolium pratense, Linn. N.O. Leguninosa.

Syn.-Trefoil, Purple Clover.

Part used-Blossoms.

Action-Alterative, sedative. Is an excellent remedy in spasmodic and bronchial coughs, whooping coughs, \&c. The infusion of I ounce to a pint of boiling water may be used freely. Generally combined with other drugs of an alterative character, as Stillingia, Lappa, Xanthoxylum, \&c. Externally Red Clover is often used as a plaster in cancer.

Preparations-Fluid extract: Dose, $\frac{1}{2}-2$ drachms. Solid extract (for use as a plaster).

Distinctive character-Flowerheads ovate, sessile, usually with a stalked trifoliate leaf and two purplishveined ovate stipules beneath the head, purplish pink, about $\mathrm{I}$ inch long and $\mathrm{I} \frac{3}{4}$ inch broad. Flowers slender, $\frac{1}{2}$ inch long, small, papilionaceous. Taste and odour, agreeable.

RED ROOT.

Ceanothus Americanus, Linn.

N.O. Celastracea.

Syn.-Jersey Tea Root.

Part used-Root.

Action-Astringent, expectorant, antispasmodic. Used internally for gonorrhoea, asthma, bronchitis, and 
pulmonary complaints. For sores in the mouth it makes an excellent wash.

\section{Preparation-Fluid extract: Dose, I-30 drops.}

Distinctive character-Root tough, woody, usually in pieces about $\frac{3}{4}$ inch thick and several inches in length, dark brown, striated, or finely wrinkled longitudinally. Fracture hard, tough, and splintery. Bark thin, deep brown, and brittle. Wood dense, reddish, concentric rings obscure, porous vessels arranged in single concentric and radiate lines. Taste, astringent. Inodorous.

\section{RED SAGE.}

\section{Syn.-Garden Sage.}

Part used-Leaves.

Action-Aromatic, astringent. Makes an excellent gargle for relaxed throat and tonsils, also for ulceration of mouth and throat. To make the gargle, pour $\frac{1}{2}$ pint of hot malt vinegar upon I ounce of leaves and add $\frac{1}{2}$ pint cold water. Use frequently.

\section{Preparation-Fluid extract: Dose, $\frac{1}{1}$ I drachm.}

Distinctive character-Stem and leaves reddish. The leaves stalked, $\mathrm{I} \frac{1}{2}-2$ inches long and $\frac{3}{4}-\mathrm{I}$ inch broad, oblong-lanceolate, rounded at the ends, crenulate at the margins, the surface strongly reticulated on both sides. Taste, pungently aromatic, astringent.

\section{RHATANY, PERUVIAN.}

Krameria triandra, $\mathrm{R}$, and $\mathrm{P}$.

Syn.-Rhatanhia.

N.O. Polygalacea.

Part used-Root.

Action-Astringent, tonic. Used internally to advantage in passive hæmorrhages, mucous discharges, and 
in menstrual disorders. Also in diarrhœa and incontinence of urine. Is useful as an application to spongy and bleeding gums.

Preparations-Powdered root: Dose, 10-30 grains. Fluid extract: Dose, 10-60 drops. Tincture B.P. and U.S.P.; Dose, $\frac{1}{2}-1$ drachm. Infusion B.P. : Dose, $\frac{1}{2}-1$ ounce. Solid extract U.S.P.: Dose, 5-8 grains. Solid extract B.P.: Dose, 5-15 grains. Conc. solut. B.P.: Dose, $\frac{1}{2}$ I drachm. Syrup U.S.P.: Dose, I drachm. Lozenges B.P.

Distinctive character-Root woody, cylindrical, branched, deep reddish brown, and rough externally, with a coarsely fibrous bark and hard, tough, woody centre. The root of Para Rhatany, derived from $K$. argentea, Mart., has transverse cracks and a short, not fibrous, fracture. Taste, very astringent. Odour, none. Varying in diameter from $\frac{1}{4}-\frac{3}{4}$ inch.

RHUBARB, EAST INDIAN, CHINA, Or TURKEY. Rheum palmatum, Linn., R. officinale, Baill. (And other species).

Part used-Root.

N.O. Polygonacee.

Action-Astringent, tonic, stomachic, aperient. In small doses the powder will cure diarrhœea; in large doses it acts as a simple and safe purgative, and is justly esteemed one of the most valuable remedies we possess. The tincture is chiefly used, but the powder is perhaps as effective and reliable.

Preparations-Powdered root: Dose, 3-30 grains. Fluid extract: Dose, 10-30 drops. Tincture comp. B.P.: Dose, $\frac{1}{2}-4$ drachms. Tincture U.S.P.: Dose, I drachm. Aromat. tincture U.S.P.: Dose, $\frac{1}{2}$ drachm. Syrup B.P.: Dose, $\frac{1}{2}-2$ drachms. Concentrated solution B.P.: Dose, $\frac{1}{2}-I$ drachm. Comp. powder B.P. (Gregory's): Dose, 20-6o grains. Comp. pill B.P.: Dose, 4-8 grains. Solid extract U.S.P.: Dose, 4 grains. Solid extract 
B.P.: Dose, $2-8$ grains. Infusion B.P.: Dose, $\frac{1}{8}-\mathrm{I}$ ounce. Syrup B.P. and U.S.P.: Dose, $\frac{1}{2}-2$ drachms. Aromatic syrup U.S.P.: Dose, 2 drachms. Rhein: Dose, I-4 grains.

Distinctive character-Chinese Rhubarb occurs in brownish yellow pieces of various size, usually perforated with a hole containing a piece of the cord used for hanging it up for drying. The outer surface is usually powdery, presents a convex or sometimes a sliced appearance, and exhibits more or less a network of white lines. Taste, nauseous, astringent. Odour, characteristic.

\section{RHUBARB, ENGLISH.}

Rheum rhaponticum, Willd.

Part used-Root.

N.O. Polygonacea.

Action-Stomachic, aperient. Similar in action to Turkey Rhubarb, though milder. Is especially useful in infantile stomach troubles and looseness of bowels. In fairly large doses it acts as a laxative.

Preparation-Powdered root: Dose, 5-60 grains.

Distinctive character-English Rhubarb, derived from Rheum rhaponticum, Willd., or from Rheum officinale, Baill., presents a shrunken surface and the transverse section shows that the bark has not been removed as in the Chinese drug. When holes are present, they are round and clean, evidently made with a rat's-tail file. The English Rhubarb, from Rheum rhaponticum, shows red veins, and that of $R$. officinale blackish veins; the latter is usually in larger pieces.

RICE.

Oryza sativa, Linn.

Part used-Seeds.

N.O. Graminacea.

Action-Nutritive, demulcent. Boiled rice is very useful in disorganized digestion, in bowel derangements, 
and in diarrhœa. Rice-water, made in a similar manner to Barley-water is used as a soothing, nourishing drink in febrile diseases and inflammatory states of intestines.

ROSE, PALE.

Rosa centifolia, Linn. N.O. Rosacea.

Syn.-Cabbage Rose, Hundred-leaved Rose.

Part used-Flower petals.

Action-Aperient. Seldom, if ever, used internally. On account of its fragrancy it is used in France for distillation of Rosewater.

Distinctive character-The petals are pink, whitish towards the base, and are usually supplied free from the calyx. The odour is that of the Cabbage Rose. Taste, slightly astringent and sweet.

ROSE, RED.

Rosa Gallica, Linn.

Syn.-Rose Flowers.

N.O. Rosacea.

Part used-Petals.

Action-Tonic, astringent. Seldom used internally. The infusion is used as a flavouring for other medicines or as a lotion in ophthalmia, \&c. The confection is mostly used in pill-making.

Preparations-Rose-water B.P.: Dose, I-2 ounces. Fluid extract: Dose, $\frac{1}{2}-\mathrm{I}$ drachm. Confection B.P. and U.S.P.: Dose, 2-4 drachms. Infusion, acid, B.P.: Dose, $\frac{1}{2}-1$ ounce. Syrup U.S.P.

The oil distilled from the fresh flowers of Rosa damascena, Mill., is the official Otto of Rose-Ol. Rosæ B.P.

Distinctive character-The Red Rose flowers consist of the unopened flowerbuds with the calyx re- 
moved. They are of deep, dark rose colour, slightly paler at the base. Taste, astringent and sweetish. Odour, that of the damask rose.

ROSEMARY.

Part used-Herb.
Rosmarinus officinalis, Linn.

N.O. Labiata.

Action-Tonic, astringent, diaphoretic. Also an excellent stomachic and nervine. Cures many cases of headache. Used externally, an infusion combined with Borax makes a good hairwash and will prevent premature baldness.

Preparations-Oil: Dose, $\frac{1}{2}-3$ drops. Spirit B.P.: Dose, 5-20 drops.

Distinctive character-Stem somewhat woody, square. Leaves linear obtuse, dark green above, white below, with branched stellate hairs, the margins strongly revolute. Flowers, when present, bluish lilac, two-lipped with two stamens only. Taste, aromatic. Odour, characteristic.

ROSINWEED.

Silphium laciniatum, Linn. N.O. Composita.

Syn.-Compass Plant, Compass Weed, Polar Plant. Parts used-Herb, root.

Action-Antispasmodic, diuretic, expectorant, emetic. It is reputed to have effected cures of dry, obstinate coughs of asthma and pulmonary catarrhal diseases. It is also beneficial in intermittent fevers.

Preparation-Fluid extract: Dose, $\frac{1}{2}-\mathrm{I}$ drachm.

Distinctive character-The article in commerce consists of broken-up leaves. The rachis of the leaves is plano-convex, with the marks of decurrent leaflets. The fragments of leaves are stiff, papery, but brittle, and without hairs, with the surface faintly reticulated. Main root I-2 inches long, and I inch in diameter, 
ending abruptly below, and laterally branched at the base, the roots enlarging downwards from $\frac{1}{1-\frac{1}{3}}$ inch in diameter, dark greyish brown, striated longitudinally; transverse section showing concentric lines and radiate structure, variegated with dark grey and white, and a small central pith. Fracture rough and fibrous. Taste, bitter and then acrid. Odour, none.

RUE.

Ruta graveolens, Linn. N.O. Rutacea.

Syn,-Garden Rue, Herb of Grace, Herbygrass.

Part used-Herb.

Action-Stimulant, antispasmodic, emmenagogue. It is chiefly used in suppression of the menses, but should not be taken in large doses, as it is liable to produce inflammation and nerve derangements. For hysteria, amenorrhœa, \&c., it will be found valuable. The infusion of I ounce to a pint of water is taken in cupful doses.

Preparations-Powdered herb: Dose, 15.30 grains. Fluid extract: Dose, $\frac{1}{2}-\mathrm{I}$ drachm.

Distinctive character-Stem cylindrical, branched, smooth. Leaves alternate, bipinnate, with oblanceolate segments, wedge-shaped below, with numerous immersed, translucent, small, round oil-glands. Flowers yellow, with five wavy petals incurved at the tips, and a gland-dotted ovary, situated on a disk. Taste, pungent, aromatic. Odour, characteristic.

RUPTUREWORT.

Part used-Herb.

Action-Astringent, diuretic. Used in catarrhal affections of the bladder.

Distinctive character-Stem slender, herbaceous, clothed with minute decurved hairs. Leaves opposite, 
oval-oblong, about $\frac{1}{16}$ inch long, at intervals of about $\frac{1}{2}$ inch. Flowers minute, greenish, sessile in the axils, approximated in the lateral branches into a slightly leafy spike. Taste, insipid. Odour, none.

SABADILLA. Schoenocaulon officinale, A. Gray. N.O. Liliacea.

Syn.-Cevadilla, Sabadilla, Veratrum officinale, Schlecht., Asagrcea officinalis, Lindl.

Part used-Seeds.

Action-Vermin destroying.

Preparations-Veratrine (alkaloid). Local irritant. Ointment (veratrine) B.P.

Distinctive character-The seeds are usually met with freed from the capsules, and are linear, pointed, shining, wrinkled and angular, or concave by mutual pressure, and contain oily albumen. The capsules are more rarely met with. They consist of thin, oblong, pointed, light brown, papery carpels about $\frac{1}{2}$ inch long, and united at their base, each containing two seeds. Taste, bitter, acrid. Odour, none.

SAFFLOWER.

Carthamus tinctorius, Linn. N.O. Composite.

Syn.-American Saffron, False Saffron, Bastard Saffron, Flores Carthami, Dyer's Saffron.

Part used-Flowers.

Action-Laxative, diaphoretic. In domestic practice these flowers are used for similar purposes as Saffron proper, as in children's and infants' complaints and 
diseases, measles, fevers, and eruptive skin complaints. The infusion made of $\frac{1}{2}$ ounce to a pint of boiling water, if taken warm, is said to restore the menstrual discharge, and will produce diaphoresis.

Distinctive character-The commercial article consists of the florets separated from the flowerheads, either loose or compressed into small circular cakes. The florets are cylindrical, slender, orange, nearly $\frac{1}{2}$ inch long, with five linear teeth. The taste is feebly bitter, and the odour not unpleasant when recent, but faintly valerianic on keeping.

SAFFRON.

Crocus sativus, Linn. N.O. Iridacea. Syn.-Crocus, Alicante Saffron, Valencia Saffron, Gatinais Saffron.

Part used-Flower pistils.

Action-Carminative, diaphoretic, emmenagogue. It has been used with benefit in amenorrhœa, dysmenorrhœa, hysteria, \&c. It arrests chronic discharges of blood from the uterus. Used as a diaphoretic, especially for children. The infusion of I drachm in a pint of boiling water is given in wineglassful to teacupful doses.

Preparations-Powdered Saffron: Dose, I2-40 grains. Tincture B.P.: Dose, 5-I 5 drops.

Distinctive character-The drug consists of the three filiform, deep orange-red stigmas attached to the upper part of the style, the whole about I-I $\frac{1}{2}$ inch long. The stigmas are tubular and slit open at the upper end, and toothed at the apex. Taste, aromatic, but characteristic. Odour, pleasant, and also characteristic. Saffron, if pure, should not contain anything different in form from the above description; should not throw down a deposit when placed in water, and should not fizz or decrepitate when burnt. 
SAGO.

Metroxylon Rumphil, Mart.

N.O. Palnacea.

Syn.-Pearl Sago, Sago Meal, Sago Flour, Sagus Rumphii, Willd., Sagus genuina.

Part used-Prepared pithstarch.

Action-Nutritive, demulcent. Mostly used in the household and for convalescents as food or demulcent.

Distinctive character-Sago occurs in various forms and sizes in commerce. Genuine Sago is rarely quite white. The ordinary Sago of commerce is often made from potato starch. The starch grains of the two plants are quite different in shape and size, those of the potato being larger with a round hilum at the smaller end, and those of Sago smaller, more or less mullershaped, with one truncate end, and a linear hilum at the larger rounded end. The heat employed in making Sago is apt to break most of the granules, but in Sago Meal or Flour they are easily distinguished.

SALEP. Orchis mascula, Linn., O. maculata, Linn., and $O$. Iatifolia, Linn.

N.O. Orchidacea.

Syn.-Salep Root.

Part used-Root.

Action-Demulcent, highly nutritious. Used for similar purposes to Arrowroot.

Distinctive character-Tubers whitish or pale brownish yellow, about I-I $\frac{1}{2}$ inch long and $\frac{1}{3}-\frac{1}{2}$ inch in diameter, oblong-oval or elliptical, somewhat cylindrical compressed, usually with a stem-scar at one end, and tapering to a point at the other. Some varieties are compressed-palmate, with three to five pointed lobes, also with a stem scar at the crown, sometimes wrinkled or shrivelled, but always horny and tough, and not easily fractured. Taste mucilaginous. Odour, none. 
Syn.-Santalwood.

Parts used-Wood, oil.

Action-Diuretic, antiseptic. Is chiefly employed in treatment of chronic mucous affections such as inflammation of bladder, gonorrhœa, and other urinary diseases. The fluid extract of the wood is often better tolerated than the oil.

Preparations-Fluid extract: Dose, I-2 drachms. Oil: Dose, 5-20 drops.

Distinctive character-This wood is usually sold in the form of fine raspings, yellowish, and of a fragrant odour. The oil is apt to be adulterated, or West Indian Sandal Wood Oil sold for it, which is obtained from a different tree (Amyris balsamifera, Linn.) and has a different odour, a lower specific gravity, and is much less soluble in 70 per cent. of alcohol.

SANICLE.

Syn.-Pool Root.

\section{Part used-Herb.}

Action-Astringent, alterative. Generally given in combination with other herbs in the treatment of blood disorders, for which it is highly esteemed. It is useful also in leucorrhœa, dysentery, diarrhœa, \&c. The infusion of I ounce to a pint of boiling water is taken in wineglassful doses.

Preparation-Fluid extract: Dose, $\frac{1}{2}-\mathrm{I}$ drachm.

Distinctive character-The herb has a nearly simple stem, reddish and furrowed, the long-stalked leaves are firm, shining green above, rather paler below, about 2-3 inches across, rounded in outline, and divided 
deeply into five irregularly trifid and serrate lobes, which are broadly wedge-shaped below. Taste, bitter, astringent, subsequently acrid. Odour, none.

\section{SARSAPARILLA, AMERICAN.}

Aralia nudicaulis, Linn.

Part used-Root.

N.O. Avaliacea.

Action-Alterative, pectoral, diaphoretic, sudorific. Though quite distinct from Jamaica Sarsaparilla, it will be found a very efficient substitute and by many is regarded as superior in alterative properties. It may be used in all cases of syphilis, skin diseases, and rheumatism, and is best given in the form of a decoction, made from I ounce of root boiled in a pint of water for half an hour, in wineglassful doses frequently. For coughs, colds, \&c., it should be used as a syrup.

Preparation-Fluid extract: Dose, I drachm.

Distinctive character-Rhizome about $\frac{3}{4}$ inch thick, with cup-shaped disks at alternate intervals of about $\frac{1}{2}$ inch, with a greyish, scaly epidermis, easily removed from the whitish bark, which itself does not adhere to the wood when dry; the woody centre is finely porous and encloses a small pith. Taste, slightly aromatic and bitterish. Odour, none. Described by Maisch as I2 inches or more long, I 1 inch thick, annulate above, with cup-shaped scars. Bark light grey, brown, exfoliating, internally whitish, with yellowish wood and spongy pith. Fracture short. Taste, mawkish and slightly aromatic.

\section{SARSAPARILLA, INDIAN.}

Hemidesmus Indicus, $\mathrm{R}$. $\mathrm{Br}$.

N.O. Asclepiadacea.

Syn.-Hemidesmus, Country Sarsaparilla.

Part used-Root.

Action-Diuretic, alterative. Used in constitutional debility, chronic rheumatism, and syphilitic skin 
diseases and ulcerations. Much thought of by the Indian natives who ascribe to it several medicinal virtues besides those mentioned.

Preparation-Syrup B.P.: Dose, $\frac{1}{2}-\mathrm{I}$ drachm.

Distinctive character-In cylindrical, transverselycracked pieces, 6 inches or more in length and about $\frac{1}{4}$ inch thick, with the corky layer often loosely attached, violet brown, or of a reddish tint. The section shows a white, mealy, corky layer, somewhat violet-tinted, and a yellowish, woody centre. Taste, pleasant, sweetish, slightly acrid. Odour, recalling heliotrope.

\section{SARSAPARILLA, JAMAICA.}

Smilax ornata, Hook. f. N.O. Liliacee.

Syn.-Smilax medica, Schlecht and Cham., Smilax officinalis, H. B. and $\mathrm{K}$.

Part used-Root.

Action-Alterative. This is the root introduced by the Spaniards in 1563 as a sure cure for syphilis. It has been thoroughly tested since then, and experience has demonstrated the fact that it is not an absolute specific. However, it contains active alterative principles, which cause it still to be held in high opinion as a general purifier of the blood. It is chiefly given in conjunction with other remedies, such as Sassafras, Burdock, \&c. It forms the chief ingredient in the Concentrated Compound Solution of Sarsaparilla of the B.P.

Preparations-Powdered root: Dose, $\frac{1}{2}-I$ drachm. Fluid extract B.P.: Dose, 2-4 drachms. Fluid extract U.S.P.: Dose, $\frac{1}{2}-1$ drachm. Solid extract: Dose, I0-20 grains. Compound solution: Dose, 2-8 drachms. Comp. syrup U.S.P.: Dose, 4 drachms. Smilacin : Dose, 2-5 grains.

Distinctive character-Root rusty brown, cylindrical, about $\frac{1}{4}-\frac{1}{2}$ inch in diameter, with numerous slender 
rootlets, deeply furrowed longitudinally, the transverse section showing a brown, hard, non-mealy bark, and a porous central wood portion. Taste, slightly acrid. Odour, none. The orange-brown native Sarsaparilla with a starchy rind is sometimes preferred. The so-called "Red" Jamaica Sarsaparilla comes from Costa Rica.

SASSAFRAS. Sassafras officinale, Nees and Eberm.

Syn.-Sassafras variifolium, Kuntze.

N.O. Lauracea.

Parts used-Bark of root, root.

Action-Stimulant, diaphoretic, diuretic. Used with success in eruptions of the skin, rheumatism, gout, \&c. A decoction is beneficial as a wash for the eyes in ophthalmia, inflammation, \&c. An infusion of I ounce of crushed bark in a pint of boiling water is taken in doses of a wineglassful, repeated frequently. Is generally given in combination with other remedies.

Preparations-Fluid extract : Dose, $\frac{1}{2}-\mathrm{I}$ drachm. Oil : Dose, $\frac{1}{2}-5$ drops. Mucilage U.S.P.: Dose, 4 drachms.

A volatile Oil of Sassafras is official in U.S.P., being distilled from the rootbark.

Distinctive character-The rootbark is of a bright, rust-brown colour, in irregular pieces, soft and brittle. The transverse fracture is short and corky, in definite layers, and shows numerous oil cells. Taste, sweetish, aromatic, slightly astringent. Odour, agreeably aromatic.

The woody root is usually sold in the form of chips of a brownish white tint, which show distinct concentric rings marked off by two or three rows of porous vessels, and slender medullary rays. The wood tastes distinctly of sassafras, but that of the stem, which is often mixed with it, does not, and is further indicated by the grey surface of the bark. 
SASSY BARK. Erythrophleum Guineense, G. Don. N.O. Leguminosa.

Syn.-Mancona Bark, Casca Bark.

Part used-Bark.

Action-Narcotic, astringent, laxative. Has been found efficient in diarrhœa, dysentery, passive hæmorrhages, \&c. The infusion is made from $\frac{1}{2}$ ounce of bark in a pint of boiling water and taken in doses of a tablespoonful as required. Used by the natives of West Africa as an ordeal in witchcraft, \&c. As it possesses toxic properties, should be used with caution.

Distinctive character-In flat or slightly curved pieces about 2 inches broad and 1 inch thick, but varying in length, externally warty, and sometimes with a grey epidermis, furrowed longitudinally, internally redbrown, hard; the inner surface nearly smooth, sometimes with black stains. Fracture coarsely granular, with numerous pale groups of stone cells. Taste, astringent, bitter, and acrid. Inodorous. Very poisonous. Should not be used except under a medical man's direction.

SAUNDERS, RED. Pterocarpus santalinus, Linn. N.O. Leguminosa.

Syn.- Rubywood, Red Sandalwood, Santalum rubrum, Lignum rubrum.

Part used-Wood.

Action-Tonic, astringent. Hardly ever used for its medicinal properties. As a colouring agent it forms part of the official Comp. Tincture of Lavender.

Distinctive character-Imported in billets, but usually met with in commerce in the form of raspings of a deep purplish red tint, which do not colour water when soaked in it. Nearly tasteless. Odour, none. 
SAVINE.

Syn.-Savinetops.
Juniperus Sabina, Linn.

N.O. Pinacea.

Part used-Tops or herb.

Action-Emmenagogue, diuretic, anthelmintic. Is sometimes combined with Tansy, Pennyroyal, and Hemlock. Although uncertain in its action, it has been used for worms in conjunction with Spigelia and Senna.

Preparations-Fluid extract U.S.P. : Dose, 5-I5 drops. Oil: Dose, I-3 drops.

Distinctive character-The herb as imported from Italy consists of small, broken, nearly cylindrical, or slightly quadrangular twigs, with deeply imbricated scale-like leaves about is inch long and lanceolate, rhombic in shape, with an oblong gland sessile in the back of the midrib. Taste, disagreeable, resinous, and bitter. Odour, recalling turpentine, but quite characteristic. The fresh plant as sold in England consists of tufts of the terminal branches about 6 inches long with the leaves longer acute and spreading, especially below, but the taste is the same. The twigs of Juniperus Virginana, Linn., and $J$. phanicea, Linn., are different in taste, and the latter has the leaves arranged in three, not four, rows.

SAYORY, SUMMER.

Syn.-Garden Savory.

Part used-Herb.

Action-Aromatic, carminative. Chiefly used as a culinary herb, but may be added to medicines for its aromatic and warming qualities.

Distinctive character-Stem woody and oppositely branched, about to inches high, with linear entire 
leaves about $\frac{1}{3}$ inch long. Flowers small, pinkish, in axillary cymes, calyx teeth five, nearly equal, linear, tapering upwards, and ciliate at the margins. Hairs on the stem short, rather rigid, decurved. Taste, aromatic, recalling thyme and marjoram, but distinct.

SAW PALMETTO. Serenoa serrulata. Hook f. N.O. Palmacea.

Syn.-Sabal serrulata, R. and S.

Part used-Berries.

Action-Nutritive tonic, diuretic, sedative. Is highly recommended in all wasting diseases, as it has a marked effect upon all the glandular tissues, increasing flesh rapidly and building up the strength. Should be used in consumption, atrophy of testes, mammæ, \&c.

Preparations-Fluid extract: Dose, $\frac{1}{2}-1$ drachm. Solid extract (alc.): Dose, 5-I 5 grains.

Distinctive character-The fruits are oval or globular, from $\frac{3}{4}-\mathrm{I}$ inch long, $\frac{5}{8}-1 \frac{1}{8}$ inch broad, externally black; with a thin, hard, but fragile pericarp covering a shrunken, pale, brown, spongy pulp, which contains oil, and a thin papery endocarp. The seed is pale brown, globular or oval, with the hilum near the base. Taste of the pulp, sweetish. Odour, none.

SCAMMONY.

Convolvulas Scammonia, Linn.

N.O. Convolvulacea.

Parts used-Root, resin.

Action-Drastic cathartic. The root is seldom used, but generally the resin prepared therefrom. Even the resin is generally combined with other cathartics, so as 
to diminish its action. Seven grains of Scammony Resin gradually rubbed well up with 3 ounces of milk forms a safe purgative, to which a taste of ginger can be added.

Preparations-Powdered root: Dose, 3-12 grains. Powdered resin B.P.: Dose, 3-8 grains. Compound powder B.P.: Dose, 10-20 grains.

Distinctive character-The resin occurs in irregular pieces, I-2 inches or more in diameter, with a black, shining fracture, brittle, powdery, and greyish externally. Taste, acrid. Odour, cheesy.

\section{SCAMMONY ROOT.}

The root occurs in large cylindrical pieces, yellowish grey externally, and somewhat twisted, often $1-2$ inches or more in diameter, tough and not easily broken, with a coarsely fibrous, starchy, and resinous fracture. The structure is rather indistinct, due to the formation of several zones in the original root. Taste, feeble, slightly acrid. Odour, resembling that of Jalap.

SCOPOLIA.
Scopola Carniolica, Jacq. N.O. Solanacea.

Syn.-Scopolia atropoides, Link.

Part used-Root.

Action-Narcotic, mydriatic. Used for similar purposes as Belladonna or Henbane, both of which it resembles very much in action. Is said to be richer in 
alkaloids than either of above, and for this reason preferred by makers of alkaloids and plasters.

Preparations-Fluid extract U.S.P.: Dose, I-5 drops. Powdered extract U.S.P.: Dose, I-5 grains.

Distinctive character-Rhizome knotty, about $\frac{1}{2}-\frac{3}{4}$ inch in diameter, with closely-approximated, large, cupshaped remains of annual stems; sometimes ending in a piece of tapering, cylindrical root, but usually consisting of the rhizome only. Fracture short.

SCULLCAP.

Scutellaria lateriflora, Linn

N.O. Labiata.

Syn.-Skullcap, Madweed.

Part used-Herb.

Action - Tonic, nervine, antispasmodic, slightly astringent. Is one of the finest nervines ever discovered, and may be prescribed wherever disorders of the nervous system exist. In hysteria, convulsions, hydrophobia, St. Vitus dance, rickets, \&c., its action is invaluable. Many cases of hydrophobia are known to have been cured by this remedy alone, while it may be regarded as a specific in St. Vitus dance. The dose of an infusion of $I$ ounce to a pint of boiling water is half a teacupful frequently.

Preparations-Powdered herb : Dose, $\frac{1}{2}$ drachm. Fluid extract : Dose, $\frac{1}{2}-1$ drachm. Solid extract : Dose, 5-Io grains. Scutellarin: Dose, I-2 grains.

Scutellaria integrifolia, Linn., S. galericulata, Linn., (European Scullcap) possess similar properties and are often used.

Distinctive character-Herb with square stems, opposite, cordate-lanceolate, shortly-stalked leaves with a tapering apex. Flowers blue, with a helmet-shaped 
upper lip, in axillary racemes. Taste, bitterish. Odour, slight.

Other species, with the flowers in one-sided terminal racemes, are sometimes substituted for it.

SCURVYGRASS.

Syn.-Spoonwort.

\section{Part used-Herb.}

Action-Antiscorbutic, diuretic. This is a strong antiscorbutic, and may be given in all cases where such a remedy is required. The infusion of 2 ounces to a pint of boiling water is taken in wineglassful doses frequently repeated.

Distinctive character-The root-leaves are longstalked, roundish, kidney-shaped, and nearly entire, the stem-leaves ovate, with a few angular teeth, becoming sessile upwards. Flowers white and cruciform, in terminal racemes. Fruit globular-ovate, two-celled, containing four red-brown seeds in each of the two cells. Taste, pungent, cress-like, bitterish, but becoming much less pungent when dry.

SEA-LAVENDER.

Statice Caroliniana, Walt. N.O. Plumbaginacea.

Syn.-Marsh Rosemary, Inkroot, Statice Limonium, Linn.

\section{Part used-Root.}

Action-Astringent. This will be found very efficient wherever an astringent tonic is needed, as in bronchial hæmorrhage, sore throat, ulcerated mouth and catarrhal disorders. Externally it is recommended for piles and as a lotion in leucorrhœa, gonorrhœea, gleet, and other 
urinary complaints. The decoction of the powdered root, I ounce to a pint, is given in doses of a wineglassful.

Distinctive character-Root large, spindle-shaped, or branched, compact, rough, of a purplish brown colour. Taste, bitter and astringent. Odour, none.

SELF-HEAL.

Syn.-Healall.
Prunella vulgaris, Linn. N.O. Labiata.

\section{Part used-Herb.}

Action-Astringent. Is useful in sore and relaxed throat also in internal bleeding, leucorrhœa, \&c. The infusion of I ounce to a pint of boiling water is taken internally in doses of a wineglassful. Externally it is used as a gargle and injection.

Distinctive character-Herb 4-8 inches long, branched, with square stems, dense, oblong-ovate, obtuse leaves, about I inch long and $\frac{1}{2}$ inch broad, usually entire, with scattered, appressed hairs. Flowers purplish blue, in a dense terminal spike, with two broad kidney-shaped acute bracts under each whorl. Upper lip of calyx with short truncate mucronate teeth. Taste, saline, faintly bitter. Odour, none.

SENEGA.

Polygala Senega, Linn. N.O. Polygalacea.

Syn.-Seneka, Senega Snakeroot.

Part used-Root.

Action-Diaphoretic, diuretic, expectorant, emetic. Very useful in chronic catarrh, chronic bronchitis, asthma, and croup. Recommended as local stimulant in sore throat. The infusion of $I$ ounce to a pint of boiling water is taken in tablespoonful to wineglassful doses.

Preparations-Powdered root: Dose, 5-20 grains. Tincture B.P.: Dose, $\frac{1}{2}-\mathrm{I}$ drachm. Fluid extract: 
Dose, 10-20 drops. Infusion B.P.: Dose, 4-8 drachms. Conc. solut. B.P.: Dose, $\frac{1}{2}-\mathrm{I}$ drachm. Syrup U.S.P. : Dose, I drachm.

Distinctive character-Root usually having a knotty crown, from which the slender stems arise, having the remains of rudimentary leaves at their base. The root is of a light yellowish grey colour, $\frac{1}{5}-\frac{1}{3}$ inch thick, usually less than three inches long, often spirally contracted and sparingly branched, and having a keel-shaped ridge running along the main root on the concave side. Fracture short and brittle, showing a cleft central column. Taste, acrid and slightly acid, and recalling that of Gaultheria, with a characteristic, somewhat rancid odour.

SENNA.

Cassia acutifolia, Del.

N.O. Leguminose.

Syn.-Alexandrian Senna, Cassia angustifolia, Vahl., East Indian Senna, Tinnevelly Senna.

\section{Parts used-Leaves, Pods.}

Action-Laxative, cathartic. Is generally combined with aromatics and stimulants to modify its griping effects. The following may be regarded as a good formula for making an infusion: Senna leaves 2 ounces, Ginger I drachm, boiling water I pint. Let it stand for one hour, strain through muslin and take in wineglassful doses. Alexandrian Senna Leaves and Pods are considered to have a milder and yet as certain an action as the East Indian variety to which they are generally preferred.

Preparations-Powdered leaves: Dose, I drachm. Syrup B.P. and U.S.P.: Dose, 2 drachms. Fluid extract, Dose, $\frac{1}{2}-\mathrm{I}$ drachm. Compound mixture B.P.: Dose, 4-I6 drachms. Compound liquorice powder B.P.: Dose, I-2 drachms. Confection B.P.: Dose, 
I-2 drachms. Fluid extract, pods: Dose, $\frac{1}{2}-\mathrm{I}$ drachm. Infusion B.P.: Dose, $\frac{1}{2}-2$ ounces. Conc. solut. B.P.: Dose, $\frac{1}{2}-I$ drachm.

Distinctive character-Senna leaves, or more properly leaflets, are greyish green, lanceolate, unequal at the base, varying from $\frac{1}{2}-1 \frac{1}{2}$ inch long, and $\frac{1}{4}-\frac{1}{3}$ inch broad. Those of Cassia angustifolia (Tinnevelly Senna) are broader near the middle, and longer in proportion than those of Cassia acutifolia (Alexandrian Senna) which are broadest below the midrib. The Mecca Senna of commerce, which seems to contain a mixture of both species, and is often full of leafstalks and discoloured leaflets, is an inferior quality. The pods are also used. Those of $C$. acutifolia are $1 \frac{1}{2}-2 \frac{1}{2}$ inches long and $\frac{3}{4}-I$ inch broad, those of $C$. angustifolia are narrower, only inch broad, and have the base of the style prominent on the upper edge. Taste, sweetish, but sickly. Odour, somewhat tea-like, but characteristic.

SHALLOT.

Syn.-Eschallot.
Allium Ascalonicum, Linn. N.O. Liliacea.

Used chiefly as an ingredient in the preparation of sauces.

Distinctive character-The bulbs are compound like those of garlic, but are much smaller and milder. The bulblets are termed cloves.

SHEEP-SORREL.

Syn.-Field-Sorrel.

Part used-Herb.
Rumex Acetosella, Linn. N.O. Polygonacee.

Action-Diuretic. The fresh plant juice is refrigerant and diaphoretic, and is of use in urinary and renal diseases. 
Distinctive character-The stem is about 6-Io inches high. The leaves are halberd-shaped, about $\mathrm{I} \frac{1}{2}$ inch long and $\frac{1}{2}-\frac{3}{4}$ inch broad. Flowers small, greenish, becoming red when in fruit, borne in leafless whorls, the male and female flowers on different individuals. Taste, acid. Odour, none.

\section{SHEPHERD'S-PURSE.}

Capsella Bursa-pastoris, Medic. N.O. Crucifera.

Syn.-Shepherd's Sprout, Mother's Heart.

Part used-Herb.

Action-Antiscorbutic, stimulant, diuretic. Chiefly used in kidney complaints and dropsy, \&c. Also useful in chronic diarrhœa. The infusion of I ounce to a pint of boiling water is taken in wineglassful doses.

Preparation-Fluid extract: Dose, $\frac{1}{1}-\mathrm{I}$ drachm.

Distinctive character-A common weed, with leaves irregular in character, somewhat lanceolate, and either entire or much toothed, but always recognisable by its triangular seed pods. The flowers are small and white. Taste, pungent. Odour, cress-like.

SIEGESBECKIA. Siegesbeckia orientalis, Linn.

Part used-Plant. N.O. Composita.

Action-Alterative, antisyphilitic. Has been used in leprous, syphilitic, and venereal skin diseases, and contains a white crystalline body resembling salicylic acid.

Distinctive character-Stem usually about 2 feet high, branched. Leaves opposite, broadly triangular, coarsely toothed. Flowerheads small, leafy, panicled, 
outer row of phyllaries spatulate and twice as long as the inner, and covered with glandular pubescence. Taste and odour, slight, but characteristic.

SILVERWEED.

Potentilla anserina, Linn. N.O. Rosacea.

Part used-Herb.

Action-Astringent, tonic.

Distinctive character-Leaves silvery below, often on the upper surface also, interruptedly pinnate, with I2-I 5 pairs of oval, toothed segments, with minute leaflets between each pair. Flowers yellow, buttercuplike, borne singly on the slender runners. Taste, astringent. Odour, none.

Syn.-Mountain Damson.

Part used-Rootbark.

Action-Tonic. Is very useful in weakened digestion, loss of appetite, and in convalescence from fevers, \&c. The infusion of $\frac{1}{2}$ ounce to a pint of boiling water is taken in tablespoonful to wineglassful doses as required.

Preparation-Fluid extract: Dose, $\frac{1}{2}-1$ drachm.

Distinctive character-The bark occurs in flat, yellowish, or greyish yellow, tough, fibrous pieces, impossible to break, and usually folded, about $\frac{1}{8}$ inch thick and $2-2 \frac{1}{2}$ inches wide. Taste, very bitter. Inodorous. 
SKUNK-CABBAGE. Symplocarpus foetidus, Nutt. N.O. Avacere.

Syn.-Skunkweed, Meadow Cabbage, Polecatweed, Dracontium fretidum, Linn.

Part used-Root.

Action-Antispasmodic, diaphoretic, expectorant. Enters into several of the Compound Herbal Powders for fever. In small doses the powder may be mixed with honey- $\frac{1}{2}$ ounce to 4 ounces honey-and forms an efficacious remedy for asthmatic and bronchial affections, in doses of $\frac{1}{2}-\mathrm{I}$ teaspoonful.

\section{Preparation-Fluid extract: Dose, $\frac{1}{2}-\mathrm{I}$ drachm.}

Distinctive character-Root obconical, truncate at both ends, 3-4 inches long and about 2 inches in diameter, with numerous long shrivelled roots. Often sold in transverse slices about $\frac{1}{4}$ inch thick with a grey-brown irregular margin, and the transverse section whitish and starchy, with scattered yellowish wood bundles showing near the circumference sections of the rootlets at their origin. Taste, acrid, biting. Odour, disagreeable.

SLIPPERY ELM.

Syn.-Red Elm, Moose Elm.

Part used-Bark.

Action-Diuretic, emollient, demulcent, pectoral ; one of the most valuable articles in the botanic practice, and should be in every household. The finely powdered bark makes an excellent gruel or food, and may be used as such in all cases of weakness, inflammation of the stomach, bronchitis, bleeding of the lungs, consumption, \&c. It has a wonderfully soothing and healing action on all the parts it comes in contact with, and in addition possesses as much nutrition as is contained in 
oatmeal. The food or gruel should be made as follows: Take a teaspoonful of the powder, mix well with the same quantity of powdered sugar and add a pint of boiling water slowly, mixing as it is poured on. This may be flavoured with cinnamon or nutmeg to suit the taste, and makes a very wholesome and sustaining food for infants. The coarse powder forms the finest poultice to be obtained for all inflamed surfaces, ulcers, wounds, burns, boils, skin diseases, purulent ophthalmia, chilblains, \&c. It soothes the parts, disperses the inflammation, draws out impurities, and heals speedily. We cannot speak too highly of this remedy, and are confident there is nothing to equal it in the world for its above-mentioned uses. Inflammation in the bowels of infants and adults has been cured, when all other remedies have failed, by an injection into the bowels of an infusion of I ounce of powdered bark to a pint of boiling water, used while warm.

Preparation-Mucilage U.S.P.; made by digesting 6 grammes (93 grains) of bruised Slippery Elm in Ioo c.c. ( 3 fl. ounces I 83 minims) of water. Should be placed in a closed vessel and heated on a waterbath for one hour and then strained.

Distinctive character-The bark occurs in flat pieces, about 2 inches wide and 2 feet or more long, usually folded, about $\frac{1}{24}$ inch thick. It has a pinkish or faintly rusty tint, a tough, fibrous texture, and mealy fracture, and is slightly striated longitudinally. Taste, very mucilaginous. Resembling lovage or fœenugreek in odour.

SMARTWEED.

Polygonum Hydropiper, Linn. N.O. Polygonacea. Syn.-Water Pepper, Arsesmart, Biting Persicaria. Parts used-Herb, leaves.

Action-Stimulant, diuretic, emmenagogue. Used principally for obstructions of the menses, amenorrhœa, 
\&c. The infusion made by pouring a pint of cold water upon I ounce of leaves is taken in wineglassful doses.

Preparations-Fluid extract: Dose, I-2 drachms. Tincture: Dose, 2-4 drachms.

Distinctive character-Stem $\mathrm{I}-2$ feet high. Leaves lanceolate, alternate, entire. Inflorescence a drooping, slender, interrupted raceme of small greenish flowers. Leaves with a pungent biting taste. Odour, none.

SNAKE ROOT.

Aristolochia Serpentaria, Linn. N.O. Avistolochiacea.

Syn.-A vistolochia veticulata, Nutt., Virginia, Red River or Texas Snakeroot.

Part used-Root.

Action-Stimulant, diaphoretic, anodyne, antispas. modic, tonic, nervine. Is a valuable remedy in all cases of fever, especially in typhoid, and will be found to agree with the digestive organs when Peruvian Bark cannot be taken. It may be employed with advantage wherever it is desirable to promote perspiration and in bilious complaints. The infusion of $\frac{1}{2}$ ounce to a pint of boiling water is taken in I-2 tablespoonful doses.

Preparations-Powdered root: Dose, ro-30 grains. Fluid extract: Dose, $\frac{1}{2}-1$ drachm. Tincture B.P. and U.S.P.: Dose, $\frac{1}{2}-1$ drachm. Infusion B.P.: Dose, $\frac{1}{2}-1$ ounce. Conc. solut. B.P.: Dose, $\frac{1}{2}-2$ drachms.

Distinctive character-Rhizome about $I$ inch long and $\frac{1}{8}$ inch thick, with numerous, filiform, matted, branching roots below, 2 inches long or more and furrowed longitudinally, and on the upper side the short bases of stems of the previous year. Taste, aromatic, camphoraceous, bitterish. Odour, aromatic.

The Texas Snakeroot, which is often sold for it, is derived from $A$. reticulata, Nutt. It has coarser, nearly 
smooth, less-branched roots, and the leaves, which are occasionally adherent, are strongly reticulated, coriaceous, and sessile.

Syn.-Quillaia, Soap Bark, Panama Bark.

Part used-Bark.

Action-Expectorant, diuretic, detergent. Used to loosen cough in chronic bronchitis and pulmonary complaints. The infusion of $\frac{1}{2}$ ounce of bark in a pint of boiling water is taken in tablespoonful doses or more as required. Used externally as a cleansing application to cutaneous ulcers and eruptions. A heading for beers is made from it.

Preparations-Fluid extract: Dose, 2.8 drops. Solid extract: Dose, $\frac{1}{2}-2$ grains. Tincture B.P. and U.S.P.: Dose, $\frac{1}{2}$-I drachm.

Distinctive character-Imported in large flat pieces I-2 feet long or more, 4- 6 inches broad, and $\frac{1}{8}-\frac{1}{4}$ inch thick. The outer surface is pale yellowish white with irregular patches of imperfectly removed reddish outer bark. The inner surface is smooth. The fracture splintery in layers. Under a lens, glittering solitary prismatic crystals of calcium oxalate are visible. The powder, when the bark is broken, causes violent sneezing. Taste, acrid. Odour, none.

A variety of the bark, apparently from a different species of the same genus, has the brown patches covering most of the bark, and marked with oblique lines. This kind is much less active, containing only half as much saponin as the genuine. 
SOAPWORT.

Saponaria officinalis, Linn.

N.O. Caryophyllacea.

Syn.-Soaproot, Bouncing Bet, Fuller's Herb.

Parts used-Leaves, root.

Action-Alterative, detergent. Used as a remedy for venereal diseases, scrofula, and skin diseases generally. Is said to be superior to Sarsaparilla. A decoction of 2 ounces boiled in a pint of water is taken in doses of I-2 tablespoonfuls three to four times a day. The root is used for producing a head on beers.

Preparations-Fluid extract: Dose, $\frac{1}{1}-\mathrm{I}$ drachm.

Distinctive character-The leaves are opposite, entire, and smooth, elliptical-lanceolate, about 2 inches long and $\frac{3}{4}$ inch broad, the longitudinal nerves curved towards the apex of the leaf, greyish green when dried. Taste, bitter and acrid. Odour, none.

SOAPWORT ROOT, EGYPTIAN.

Gypsophila Struthium, Linn.

Distinctive character-The root occurs in pieces 4-6 inches long, and from $\frac{1}{2}-1 \frac{1}{2}$ inch in diameter, of a yellowish white colour, longitudinally furrowed externally, with paler spots where the cortex has been rubbed. The transverse section shows a radiate and concentric structure. Taste, bitter, then very acrid. Odour, feeble. Powder very irritating to the nostrils. A smaller root, but with similar structures and properties, comes from Spain.

SOLOMON'S SEAL.

Polygonatum multiflorum, Allem. N.O. Liliacea.

Part used-Root.

Action - Astringent, demulcent, tonic. Useful in female weakness, fluor albus, \&c. Combined with other 
remedies, it may be given in pulmonary complaints, consumption, and bleeding of lungs. The powdered root also makes an excellent poultice for bruises, piles, inflammations, and tumours. The infusion of 1 ounce to a pint of boiling water is taken in wineglassful doses. Also used externally as an injection.

Distinctive character-Rhizome cylindrical, somewhat flattened above, with circular stem scars at intervals, about $\frac{1}{2}$ inch in diameter and $2-3$ inches or more long, with transverse ridges. Fracture short, waxy, yellowish. Taste, mucilaginous, sweetish, then bitter and acrid. Odour, none.

\section{SORREL.}

Part used-Leaves.

Action-Refrigerant, diuretic. May be used as a cooling drink in all febrile diseases. The leaves are occasionally eaten as a salad or boiled as spinach. In cutaneous tumours the following preparation has been used: Burnt Alum I drachm, Citric Acid 2 drachms, inspissated juice of Sorrel I ounce, water to ro ounces; applied as a paint.

Distinctive character-Leaves oblong, arrow-shaped below, rather firm, with a broad-toothed, membranous, stipular sheath round the stem at its base. Taste, acid and astringent. Odour, none.

SOUTHERNWOOD. Artemisia Abrotanum, Linn.

Syn.-Old Man, Lad's Love.

N.O. Composita.

Part used-Herb.

Action-Stimulant, emmenagogue, antiseptic, detergent. This well-known garden plant is used to promote 
the flow of the menses. For worms in children it is given in teaspoonful doses of the powder in treacle morning and evening. The infusion of I ounce of herb to a pint of boiling water is taken in wineglassful doses.

Preparation-Fluid extract: Dose, $\frac{1}{2}-\mathrm{I}$ drachm.

Distinctive character-Leaves greyish green, stalked, twice pinnate, with very slender, linear, pointed segments, covered with minute white pubescence. Taste, bitterish, aromatic. Odour, sweet, characteristic.

Syn.-Mackerel Mint, Mentha spicata, Linn.

Part used-Herb.

Action-Stimulant, carminative, antispasmodic. This herb is added to many compounds on account of its carminative properties and its pleasant taste. The infusion of I ounce in a pint of boiling water is taken in doses of a wineglassful or less as may be required. For infantile troubles generally the sweetened infusion is an excellent remedy.

Preparations-Fluid extract: Dose, $\frac{1}{4}-\mathrm{I}$ drachm. Oil. Water B.P. and U.S.P.: Dose, 4 drachms. Spirit U.S.P.: Dose, 30 drops.

Distinctive character-The true Spearmint has sessile, elliptic-oblong, sharply-serrate leaves, smooth and strongly-ribbed below. Taste and odour, characteristic. Flowers in axillary whorls approximated so as to form a tapering spike. In Mentha cardiaca, J. G. Baker, which is sometimes sold as Spearmint, the leaves are smaller, and the whorls of flowers are distant and leafy. 
SPEEDWELL.

Part used-Herb.

Action-Alterative, expectorant, diuretic. Useful in coughs, catarrhs, \&c. It promotes menstruation and is a simple and effective remedy in skin diseases.

Distinctive character-Stems slender and shortly hairy. Leaves opposite, oval, obtuse, serrate, shortly stalked, $\frac{1}{2}-\frac{3}{4}$ inch long, and $\frac{1}{4}-\frac{8}{8}$ inch broad. Flowers small, blue, in axillary spikes. Taste, bitter and astringent. Odour, slightly tea-like when dry.

SPIKENARD, AMERICAN. Aralia racemosa, Linn. N.O. Avaliacea.

Syn.-Spignet, Pettymorrel, Indian Spikenard.

Part used-Root.

Action-Alterative, diaphoretic. Used in rheumatic, pulmonary, syphilitic, and cutaneous disorders. The infusion of $\frac{1}{2}$ ounce in a pint of boiling water is taken in wineglassful doses.

Preparations-Fluid extract: Dose, $\frac{1}{2}$-I drachm.

Distinctive character-Rhizome oblique, 4-6 inches long, with prominent, concave stem scars, about $\mathrm{I}$ inch broad in diameter. Roots about I inch thick at the base, pale brown, wrinkled. Fracture short and whitish. Taste, aromatic. Odour, similar.

SQUAW-VINE.

Mitchella repens, Linn. N.O. Ericacea. Syn.-Partridgeberry, Checkerberry, Winter Clover, Deerberry.

Part used-Herb.

Action-Parturient, diuretic, astringent. Used in dropsy, diarrhœa, and suppression of urine. Has been 
found highly beneficial in uterine derangements, such as amenorrhœa, dysmenorrhœa, menorrhagia, \&c. The decoction of 2 ounces in a pint of water is taken in wineglassful doses.

Preparation-Fluid extract: Dose, $\frac{1}{2}-I$ drachm.

Distinctive character-Stem slender, with a deep furrow on one side, creeping. Leaves opposite, evergreen, nearly sessile, $\frac{8}{8}$ inch long and $\frac{1}{2}$ inch broad, roundish, broadly ovate, and smooth. Flowers in pairs, corolla four-lobed, bearded inside, pinkish. Fruit baccate, red, four-seeded. Taste, astringent, bitter. Odour, none.

SQUILL.

Urginea Scilla, Steinh. N.O. Liliacea.

Syn.-Scilla maritima, Linn., Uvginea maritima, Baker.

Part used-Bulbs.

Action-Diuretic, expectorant, cathartic, emetic. Is useful in small doses to relieve irritation of mucous surfaces and check excessive secretions. Used extensively in dropsy not due to organic changes. Also as an expectorant in catarrh, asthma, pneumonia, cough, and chronic bronchial affections.

Preparations-Powdered bulb: Dose, 2-I2 grains. Fluid extract: Dose, I-Io drops. Tincture B.P. and U.S.P.: Dose, 5-I5 drops. Syrup B.P.: Dose, $\frac{1}{8}-I$ drachm. Vinegar B.P.: Dose, 10-30 drops. Oxymel B.P.: Dose, $\frac{1}{2}-I$ drachm. Comp. syrup U.S.P.: Dose, $\frac{1}{2}$ drachm.

Distinctive character-The large bulbous root is usually cut up, and the dried curved segments, met with in commerce, are about $\mathrm{I} \frac{1}{2} \cdot 2$ inches long and $\frac{1}{8}-\frac{1}{2}$ inch wide, yellowish white, tough, and often flexible. Fracture short. Taste, bitterish and acrid. The powder rapidly attracts moisture, and forms a solid mass unless air is excluded. 
ST. JOHN'S WORT. Hypericum perforatum, Linn.

\section{Part used-Herb.}

N.O. Hypericacea.

Action-Slightly astringent, expectorant, diuretic. Useful in coughs, colds, consumption, and all lung diseases generally. It is highly esteemed in affections of the urinary passages. The infusion of $I$ ounce to a pint of boiling water is taken in wineglassful doses. The fresh flowers infused in Olive Oil make the Oil of St. John's Wort, a healing application to wounds, sores, ulcers, and swellings.

Preparation-Fluid extract: Dose, $\frac{1}{2}-\mathrm{I}$ drachm.

Distinctive character-Stem angular, I-I $\frac{1}{2}$ foot high. Leaves opposite, sessile, oval, and oblong, with small black dots on the edges, and numerous transparent, round oil glands immersed in the surface. Flowers yellow, with numerous stamens arranged in three bundles, and the ovary has three dark red styles. Taste, aromatic, bitter, and astringent.

STAR-ANISE.

Illicium verum, Hook, $\mathrm{f}$.

N.O. Magnoliacea.

Syn.-Chinese Anise, Star-Anise Fruits, Badiana, Anisa stellata.

Parts used-Seeds, oil.

Action-Stimulant, carminative, diuretic. For uses see Anise, which it resembles very much in properties and action. The dose of the powdered seeds is from IO-20 grains, of the oil I-Io drops.

Distinctive character-Fruits about $I$ inch in diameter, formed of eight boat-shaped carpels, open when ripe, each containing one smooth, oval, polished brown seed. Pericarp brown, wrinkled below, and 
beaked at the apex. Taste, sweet, aromatic, fennel or anise-like. The odour is similar.

A spurious kind, the fruit Illicium religiosum, Sieb. and Zucc., with similar shape, but rather shorter, with a turpentiny taste, imported from Japan, is sometimes met with. It possesses poisonous properties. The oil resembles Oil of Aniseed, and can only be distinguished by chemical tests.

STAVESACRE.

Delphinium Staphisagria, Linn. N.O. Ramunculacea.

Syn.-Starvesacre, Staphisagris.

Part used-Seeds.

Action-Vermifuge and vermin destroying. Used as lotion, wash, or ointment for destroying lice in hair, \&c.

Preparations-Ointment B.P. Fluid extract U.S.P.: Dose, I drop.

Distinctive character-The seeds are greyish black, wrinkled and pitted, more or less triangular, or foursided, with the back convex, about $\frac{3}{4}$ inch long and rather less in width, ten weighing about 6 grains. Albumen oily. Taste, bitter and tingling. Odour, none.

\section{STONECROP, VIRGINIA.}

Penthorum sedoides, Linn. N.O. Crassulacea.

Syn.-Ditch Stonecrop, Penthorum.

Part used-Herb.

Action-Astringent, laxative, demulcent. Has been employed successfully in the treatment of diarrhœa, hæmorrhoids, cholera infantum, \&c. It is of value in 
catarrhal gastric disorders in general. This drug is of undoubted power, and deserves a careful study.

Preparation-Fluid extract: Dose, $\frac{1}{2}-\mathrm{I}$ drachm.

Distinctive character-Stem about I foot long. Leaves alternate, short-stalked, 2-3 inches long and one-third as broad, lanceolate, acute, serrate, smooth, and thin. Flowers small greenish, in rows along the upper sides of the branches of the terminal cyme, fiveparted, with ro stamens. Taste, slightly astringent. Odour, characteristic.

STONE ROOT. Collinsonia Canadensis, Linn. N.O. Labiata.

Syn.-Rich Weed, Rich Leaf, Knob Root, Knob Weed, Horsebalm, Horseweed.

Part used-Root.

Action-Stomachic, diuretic, tonic. Is regarded by many as a certain remedy in cases of gravel, stone in the bladder, piles, \&c. As a general diuretic it is undoubtedly of great value. It is largely used among American veterinary surgeons as a diuretic. As a gargle use I part of fluid extract to 3 of water.

Preparations-Fluid extract: Dose, I5-60 drops. Collinsonin: Dose, 2-4 grains.

Distinctive character-Rhizome brown-grey, about 4 inches long, with knotty, short, irregular branches, and numerous shallow stem scars, very hard, with a thin bark, irregular woody wedges, and numerous brittle rootlets. Taste, bitterish, disagreeable. Odour, none.

STORAX.

Liquidambar orientalis, Mill. N.O. Hamamelidacea.

Syn.-Styrax, Prepared Storax, Liquid Storax, Balsam Styracis.

Part used-Balsam.

Action-Expectorant, stimulant. Like most balsams it acts very beneficially upon the mucous membranes, 
and has been used internally in asthma, bronchitis, catarrh, cough and pulmonary affections; externally in gonorrhœa, gleet, and leucorrhœa. The ointment forms a valuable application in a number of cutaneous disorders such as scabies, ringworm, \&c. The dose is from Io-20 grains.

Distinctive character-A viscid, treacly liquid, greyish brown, opaque, heavier than water. It always contains water, and when long kept or heated the water separates, leaving a dark-brown transparent layer. Taste, sharply pungent, burning, and aromatic. Odour, recalling that of hyacinth.

STRAMONIUM.

Datura Stramonium, Linn. N.O. Solanacea.

Syn.-Thorn Apple, Jamestown Weed, Jimson Weed, Stinkweed.

Parts used-Leaves, seeds.

Action-Antispasmodic, anodyne, narcotic. It acts similarly to Belladonna, and does not constipate. The inhalation of the smoke from the burning leaves is recommended for relieving attacks of asthma. It is a better cough remedy than Opium, as it does not arrest secretions.

Preparations-Powdered leaves: Dose, $\frac{1}{10}-5$ grains. Fluid extract, leaves: Dose, I- 3 drops. Tincture, leaves B.P. and U.S.P.: Dose, 5-I5 drops. Fluid extract, seeds: Dose, I-2 drops. Powd. extract U.S.P.: Dose, $\frac{1}{8}$ grain. Solid extract B.P.: Dose, $\frac{1}{4}-1$ grain. Ointment U.S.P.

Distinctive character-Stem widely forked or ternate. Leaves long-stalked, unequal at the base, somewhat fleshy, ovate, sinuate-dentate, with large, irregular, pointed teeth, glabrous when mature. Flowers white, tubular, with five teeth, funnel-shaped when open, falling 
of with upper part of calyx. Capsule spiny. Taste, bitter and saline. Odour, when fresh, rank and disagreeable, but tea-like when dried. The under surface of the leaf, when dry, is minutely wrinkled. Seeds black, kidney-shaped, flat, about $\frac{1}{6}$ inch long and $\frac{1}{24}$ inch thick, reticulated and finely pitted, the embryo coiled in white oily albumen, parallel to the face of the seed.

STRAWBERRY.

Part used-Leaves.
Fragaria vesca, Linn. N.O. Rosacece.

Action-Mildly astringent, diuretic. Used in children's diarrbœa and affections of the urinary organs. The infusion of $I$ ounce to a pint of boiling water is taken in doses from a teaspoonful to a wineglassful.

Distinctive character-Leaves long-stalked, trifoliate, leaflets obovate, shortly stalked, paler beneath,

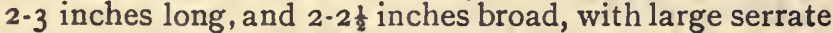
teeth, feather-veined, the veins erect, each ending in a tooth. Taste, astringent. Odour, feeble.

STROPHANTHUS.

\section{Part used-Seeds.}

Action-Cardiac tonic. Used in muscular debility of heart and cardiac pains with dyspnœe. This drug should be used very cautiously owing to its great variation in strength.

Preparations-Tincture B.P. and U.S.P.: Dose, 5-I 5 drops. Powdered extract B.P.: Dose, $\frac{1}{4-I}$ grain.

Distinctive character-Seeds greenish brown, $\frac{1}{2}$ inch long and $\frac{1}{8}$ inch broad, with appressed hairs, elliptical, furnished with a long awn. A section of the seed gives 
a deep green colour with a mixture of strong sulphuric acid 8 parts, and water 2 parts, recently made. The seeds of S. hispidus, D.C., are smaller and brown, but give the same reaction.

SUMACH, SMOOTH.

Rhus glabra, Linn.

N.O. Anacardiacee.

Syn.-Upland Sumach, Pennsylvania Sumach.

Parts used-Bark, berries.

Action-Astringent, alterative, tonic. Berries : refrigerant, diuretic. The bark is useful in diarrhœa, dysentery, gonorrhœa, and leucorrhœa. The decoction of I ounce to a pint of water is used in doses of a wineglassful or more internally, externally as an application or lotion. The berries are used in bowel complaints, febrile diseases, \&c. An infusion of I ounce of berries in a pint of boiling water is taken in wineglassful doses.

Preparations-Fluid extract, bark: Dose, I-2 drachms. Fluid extract, berries: Dose, I-2 drachms. Rhusin: Dose, I-2 grains.

Distinctive character-The root bark occurs in quilled pieces about 2 inches long and $\frac{1}{8}-\frac{1}{4}$ inch in diameter, dull reddish brown, with scattered transversely-oval lenticels. Fracture whitish or brown, with transverse rows of minute blackish, linear oil cells. Taste, gummy, astringent. Odour, none.

SUMACH, SWEET.

Syn.-Fragrant Sumach.

Part used-Bark of root.

Action-Astringent, diuretic. Largely used in diabetes and in the treatment of excessive discharges 
from kidneys and bladder. Valuable in treatment of incontinence of urine in children and aged persons. Also in leucorrhœa, diarrhœa, and dysentery. The infusion of $\mathrm{r}$ ounce to a pint of boiling water is taken in wineglassful doses. Externally may also be used as an injection.

Preparation-Fluid extract: Dose, $\frac{1}{2}-\mathrm{I}$ drachm.

Distinctive character-The root bark occurs in small quilled pieces about $\frac{1}{t}$ inch in diameter and 2 inches or more long, of a dirty brown colour externally, with scattered transversely oval red-brown lenticels. Transverse fracture short, with radiate rows of minute, dark, flattened oil cells. Taste, mucilaginous. Odour, none.

\section{SUMBUL.}

Syn.-Musk Root.

Part used-Root.

Action-Nerve stimulant, antispasmodic, tonic. Has been found very useful in nervous diseases, in low typhus fevers, asthma, bronchitis, \&c. Also employed in amenorrhœa, hysteria, and other allied female disorders.

Preparations-Fluid extract: Dose, Io-6o drops. Solid extract U.S.P.: Dose, 4 grains. Tincture B.P.: Dose, $\frac{1}{2}$-I drachm.

Distinctive character-The root occurs in commerce in transverse slices, about I-2 inches, rarely up to 5 inches in diameter, and $\mathrm{r}$ inch or more thick, the bristling crown of the root and the tapering lower parts of the root also occur, externally covered with a thin, papery, dark grey-brown bark. The transverse section is dirty brown and resinous, marbled with white. The white part is seen to consist of a spongy, fibrous, mealy tissue; Taste, bitter and aromatic. Odour, musky. 
SUNDEW.

Drosera rotundifolia, Linn. N.O. Droseracea.

Syn.-Roundleaved Sundew, Dewplant, Red Rot.

Part used-Herb.

Action-Pectoral, expectorant, demulcent, antasthmatic. Exerts a peculiar effect upon the respiratory organs. In small doses it is almost a specific in dry, spasmodic, and tickling coughs, also in whooping cough, for which it is considered a good prophylactic. An infusion of $\frac{1}{2}$ ounce in a pint of boiling water may be taken in tablespoonful doses as required. The fresh juice has been used as an application to warts and corns.

Preparations-Fluid extract: Dose, 10-20 drops. Solid extract (alc.): Dose, 2-5 grains.

Distinctive character-Leaves all radical, six to ten in number, reddish, orbicular, fleshy, covered with stalked, sticky glands. Flowering stem leafless, about 4 inches high, bearing small white flowers. An allied species, D. longifolia, Linn., has larger, linear-oblong leaves.

SUNFLOWER.

Syn.-Helianthus.

\section{Part used-Seeds.}

Action-Diuretic, expectorant. This drug has been successfully used in bronchial, laryngeal, and pulmonary affections, coughs and colds. The following preparation has been found efficacious: Sunflower seeds, 2 ounces, I quart of water; boil down to I2 ounces and strain, add 6 ounces of good Holland gin and 6 ounces of sugar. The dose is $\mathrm{I}-2$ teaspoonfuls three to four times a day. An oil contained in the seeds has also been found to 
possess similar properties, and may be given in doses of ro-I 5 drops, or more, two to three times a day.

Distinctive character-Seeds, or more correctly fruits, opaque white in colour, obovate or shortly wedge-shaped, broader and truncate at the apex, but convex, compressed on two sides which meet and form two sharp margins. The black variety has a black glossy surface and is rather larger and thinner as a rule, but otherwise does not differ from the white variety, which sometimes has black longitudinal stripes. Seed white, oily. Taste, nutty. Odour, none.

SWAMP-MILKWEED. Asclepias incarnata, Linn.

N.O. Asclepiadacea.

Syn.-Swamp-Silkweed, Rose-coloured Silkweed.

Part used-Root.

Action-Emetic, cathartic. Has been recommended in rheumatic, asthmatic, and catarrhal affections, and as a vermifuge. It acts as a good stomachic and a quick diuretic, and is taken as an infusion, hot or cold, made of $\frac{1}{2}$ ounce of root in powder to a pint of boiling water. The dose of the powder is from I 5-60 grains.

Distinctive character-Rhizome about $I$ inch in diameter, irregularly globular or oblong, yellowish brown, hard, knotty, with a thin bark, tough whitish wood, and rather thick central pith. Rootlets about 4 inches long, light brown. Taste, sweetish, acrid, and bitter. Inodorous.

TAG ALDER.

Alnus serrulata, Willd. N.O. Betulacea.

Syn,-Common Alder, Smooth Alder, Red Alder, Alnus rubra, Desf.

Part used-Bark.

Action-Tonic, alterative, astringent, emetic. Used in syphilitic and scrofulous conditions. Also of impor- 
tance in indigestion and dyspepsia caused by debility of stomach. Where diarrhœa is caused by the same complaints it will be found of great utility. The infusion of I ounce of bark in a pint of boiling water is taken in wineglassful doses.

Preparations-Fluid extract: Dose, $\frac{1}{2}-I$ drachm. Alnuin: Dose, 4-Io grains.

Distinctive character-Bark blackish grey, with small corky warts, inner surface orange-brown, striated. Fracture uneven, but not fibrous. Taste, astringent and somewhat bitter. Almost odourless.

TAMARAC.

Larix Americana, Michx. N.O. Conifera.

Syn.-American Larch, Black Larch, Hackmetack, Pinus pendula, Salisb.

Part used-Bark.

Action-Alterative, diuretic, laxative. Recommended in jaundice, obstructions of liver, rheumatism, and cutaneous disorders. The decoction of the bark, combined with Spearmint, Juniper, Horseradish, \&c., taken in wineglassful doses, has proved valuable in dropsy. Externally it has been used in piles, menorrhagia, dysmenorrhœa, \&c.

Distinctive character-In dull purplish brown fragments, about I-2 inches broad and long, with irregular depressions on the outer surface, and smooth, finely striated on the inner. Fracture shortly fibrous and laminate. Taste, mucilaginous, astringent, and faintly terebinthenous. Odour, none.

TAMARINDS.

Tamarindus Indica, Linn. N.O. Leguminosa.

Syn.-Tamarind fruit, Tamarind pulp, Tamarindus officinalis, Hook.

Parts used-Fruit, pulp. 
Action-Nutritive, refrigerant, laxative. These form a part of the official Confection of Senna, but they may be used equally well by themselves in doses of $2-4$ drachms. In smaller quantities and diluted with water they form an agreeable refrigerating drink in febrile diseases. One ounce of the pulp boiled in a pint of milk and strained forms Tamarind whey.

Distinctive character-West Indian Tamarinds consist of the fruits, after removal of the pericarp, preserved in syrup, and are the kind chiefly used in medicine. East Indian Tamarinds arrive without being preserved in syrup, but with the pericarp removed. Egyptian Tamarinds arrive pressed into bun-shaped cakes. The two last varieties are used for sauces, chutney, \&c.

TANSY.

Part used-Herb.
Tanacetum vulgare, Linn. N.O. Composita.

Action-Anthelmintic, tonic, emmenagogue. Largely used for expelling worms in children. Also valuable in female disorders, such as hysteria, nausea, \&c., and in kidney weakness. The infusion of I ounce to a pint of boiling water should be taken in teacupful doses night and morning fasting, for worms. In other complaints, a wineglassful repeated frequently.

Preparations-Fluid extract: Dose, $\frac{1}{3}-2$ drachms. Solid extract: Dose, 5-10 grains.

Distinctive character-Stem with alternate, oblong leaves, about 6-8 inches long, and about 4 inches wide, deeply cut in a pinnate manner, dark green, with about I2 pointed, serrate segments on either side, and a terminal one, attached to a toothed midrib or rachis. Taste, bitter and aromatic. Odour, strong and characteristic, disagreeable. 
TAPIOCA. Jatropha Manihot, Linn. N.O. Euphorbiacea.

Syn.-Manihot, Mandioc, Tapioca Meal, Brazilian Arrowroot, Cassava Starch, Manihot utilissima, Pohl, Janipha Manihot, Kunth.

Part used-Rootstarch.

Action-Nutritive, demulcent. It makes an excellent article of diet for infants and invalids, and may be sweetened or used in combination with fruits, preserves, wines, or spices.

Distinctive character-Tapioca, like sago, is often prepared from potato starch. Under the microscope, the genuine is easily distinguished, especially in the form of meal, by the truncate muller-shaped starch grains, with a central hilum.

TEA.

Camellia Thea, Link. N.O. Camelliacea.

Syn. - Thea Chinensis, Sims ; Camellia theifera, Griff.

Part used-Leaves.

Action-Stimulant, astringent. Tea is perhaps the most important article in the domestic economy, where the freshly-made infusion forms the beverage at one os more meals during the day. Its general effect is stimulating, and it also acts as a nerve sedative and frequently relieves headache. Occasionally it causes unpleasant nervous and digestive disturbances.

Distinctive character-Indian and Ceylon tea often produce nervous symptoms in those unaccustomed to their use. China tea rarely produces such an effect. This is probably due to the method of manufacture. The latter is often blended with the Indian. China tea is often flavoured artificially by placing bags of dried scented flowers amongst it, Jasminum, Chlovanthus, \&c. 
THUJA.

Thuja occidentalis, Linn. N.O. Conifera.

Syn.-Arbor Vitæ, Yellow Cedar, Tree of Life, False White Cedar.

Parts used-Leaves, tops.

Action-Anthelmintic, irritant, expectorant, emmenagogue. Recommended in chronic coughs, fevers, gout, amenorrhcea, \&c. Is also used as an outward application for removal of warts and fungoid growths. The infusion of $\mathrm{I}$ ounce in a pint of boiling water is taken internally in tablespoonful to wineglassful doses; also used externally as a lotion or injection.

Preparation-Fluid extract: Dose, $\frac{1}{3}-\mathrm{I}$ drachm.

Distinctive character-The spreading, flat, fan. shaped, pinnate branches are furnished with scale-like leaves so closely imbricated and appressed that they are easily overlooked. They are opposite, broadly awlshaped, the points projecting more on the stems than on the branchlets. Taste, bitter and camphoraceous. Odour, recalling strawberries and juniper, characteristic, not agreeable.

THYME.

- Syn.-Garden Thyme.

Part used-Herb.

Action-Tonic, antiseptic, antispasmodic. Generally used in combination with other remedies. The infusion of I ounce in a pint of boiling water is taken in doses of a wineglassful repeated frequently.

Preparations-Fluid extract: Dose, $: \frac{1}{2}-I$-drachm. Oil: Dose, I-Io drops.

Distinctive character-Stems 4-8 inches high, with opposite, small, elliptical, greenish grey, shortly- 
stalked leaves, about $\frac{1}{8}$ inch long and $\frac{1}{16}$ inch broad, reflexed at the margin. Taste and odour, aromatic.

The garden variety known as Lemon Thyme has a lemon flavour as well as that of Thyme proper, and differs in the rather broader leaves not recurved at the margin, and is referred by botanists to the next species as var. citriodorus.

THYME, WILD.

Thymus Serpyllum, Linn. N.O. Labiata.

Syn.-Mother of Thyme, Serpyllum.

Part used-Herb.

Action-Antispasmodic, carminative, tonic. Favourable results have been obtained in convulsive coughs, whooping coughs, catarrh, and sore throat from the use of this herb. The infusion should be given. It is prepared with I ounce of herb to a pint of boiling water, sweetened with sugar or honey and made demulcent by Linseed or Acacia. This is given in doses of $\mathrm{I}$ or more tablespoonfuls several times daily.

Distinctive character-Plant resembling the last, but the leaves are $\frac{1}{8}$ inch broad, tapering below, green, ciliate at the base, not recurved at the margins, and have the veins prominent on the under surface. The odour is weaker than that of Thymus vulgaris.

TOBACCO.

Nicotiana Tabacum, Linn.

N.O. Solanacea.

Syn.-Leaf Tobacco, Tobacco leaf, Tabacca.

Part used-Leaves.

Action-Narcotic, sedative, emetic. In the employment of Tobacco as a medicinal agent much care should be exercised, as it produces great depression, emesis, 
and convulsions, sometimes by very moderate doses. Internally it is for this reason seldom used. As an ointment, made by simmering the leaves in lard, it has been employed in curing old ulcers and painful tumours. The leaves were official in B.P. 1885 .

Distinctive character-Several species are employed to yield tobacco. N. Tabacum yields Virginian; N.acuminata, R. Grah., Latakia; N. rustica, Linn., a good deal of Persian tobacco; but there are many varieties of N.Tabacum itself. Some of these can be distinguished under the microscope.

TOLU BALSAM. Myroxylon Toluifera, H. B. \& K. N.O. Leguminosa.

Syn.-Balsam Tolu, Toluifera Balsamum, Baill.

Part used-Balsam.

Action-Stimulant, tonic, expectorant. Used in chronic catarrbs, pulmonary and bronchial affections, coughs, \&c.

Preparations-Tincture B.P. and U.S.P.: Dose, $\frac{1}{2}$-I drachm. Syrup B.P. and U.S.P.: Dose, $\frac{1}{2}-I$ drachm.

Distinctive character-A light brown, fragrant, balsamic resin, softening in the warm hand, but on keeping becomes brittle in winter. In a thin, even layer between two warmed pieces of glass it is seen to be transparent and to contain numerous crystals of cinnamic acid. Taste, sweetly aromatic and faintly acid. Odour, recalling vanilla, but different.

TONKA-BEANS.

Dipteryx odorata, Willd.

Syn.-Coumarouna odorata, Aubl.

N.O. Leguminose.

Part used-Seeds.

Action-Aromatic, narcotic, cardiac tonic. Although this drug has been used in whooping cough, it seems to 
have fallen into disuse, probably owing to its heartparalyzing effects in large doses. It contains an odorous principle, Coumarin, which is largely used as a flavouring and perfume.

Distinctive character-The beans are about $\mathrm{I}-2$ inches long, black, wrinkled, nearly $\frac{1}{2}$ inch in diameter, flattened, with one edge sharp. They vary in size and appearance. The Surinam beans are often greyish, and the largest, Angustura beans are more slender, long and shining; the Para shorter and smaller. Some varieties are covered with a greyish efflorescence of crystals of coumarin. These have been steeped in rum, which removes a good deal of the coumarin. The odour resembles that of new-mown hay.

TORMENTILLA.

Syn.-Septfoil.
Potentilla Tormentilla, Neck. N.O. Rosacea.

\section{Parts used-Root, herb.}

Action-Tonic, astringent. The root being the stronger is mostly used, and may be given in all cases of relaxed bowels, diarrhœa, and cholera, \&c. The infusion of $\mathrm{I}$ ounce of herb to a pint of boiling water is taken in wineglassful doses as required. As a lotion it is applied to ulcers and old sores as a wash. The fluid extract acts as a styptic to cuts, wounds, \&c. This root may be regarded as one of the safest and most powerful of astringents.

Preparation-Fluid extract, root: Dose, $\frac{1}{2}-\mathrm{I}$ drachm.

Distinctive character-In dull brown, hard, cylindrical, shortly tapering pieces, rough on the surface, with irregularly rounded elevations, and pits or depressed stem scars, and minute scars of filiform rootlets. Fracture short, light brownish red, showing small, distant wood bundles in one or two distant circles, and a large pith. 
Syn.-Gum Tragacanth, Syrian Tragacanth.

Part used-Gummy exudation.

Action-Mucilaginous, demulcent. Occasionally it is used as a remedy in cough or diarrhœe where demulcents are desirable, but mostly in the shape of a mucilage for the purpose of suspending heavy, waterinsoluble powders, such as bismuth or zinc preparations. The powder forms an ingredient in most lozenges and in many emulsions.

Preparations-Mucilage of Tragacanth B.P. and U.S.P. Comp. Powder B.P.: Dose, 20-60 grains.

Distinctive character-This gum occurs in flat pieces marked with curved lines. It is hard and tough, and, in the Smyrna kind, yellowish white. In the Persian kind it is thinner, slightly flexible, white, but translucent, and often in longer, but twisted pieces. An inferior, often reddish tinted, thicker kind is sold for technical purposes, for smoothing boot leather, \&c. The Syrian is preferred for toilet preparations, such as bandoline, as it makes a white mucilage. Tragacanth loses on drying about I4 per cent. of water. It swells up in water and forms a mucilage with even 50 parts of water, but only a portion of it soluble. It dissolves in alkali, but gives a yellow solution. It yields only 4 per cent. of ash.

TREE-OF-HEAVEN. Allanthus glandulosa, Desf. N.O. Rutacea.

Syn.-Ailanto, Chinese Sumach.

Parts used-Bark, rootbark.

Action-Antispasmodic, cardiac depressant, astringent. The bark has been used with success in dysen- 
tery, diarrhœa, gonorrhœa, leucorrhœea, and also for tapeworm; but its nauseating effects upon human beings render it undesirable. The rootbark is employed in heart complaints, asthma, and epilepsy. The doses should not exceed 20 grains of the powder.

Distinctive character-Bark brownish grey, with numerous warts, and on some pieces large, triangular scars of leaf bases; the inner surface is striated longitudinally. Fracture short, in the outer, pale buffcoloured, and fibrous in the inner part, the fibres forming a porous layer. Taste, bitter and slightly acrid. Odour, scarcely any.

\section{TURKEY CORN.}

Dicentra Canadensis, DC.

N.O. Fumariacea.

Syn.-Turkey Pea, Squirrel Corn, Staggerweed, Corydalis, Corydalis Canadensis, Gold.

\section{Part used-Root.}

Action-Tonic, diuretic, alterative, antisyphilitic. In the treatment of syphilitic disorders, it is generally combined with other remedies, and acts especially well in conjunction with Queen's Delight, Burdock, or Prickly Ash. Is also recommended in menstrual complaints. The infusion of $\frac{1}{2}$ ounce to a pint of boiling water is taken in wineglassful doses.

Preparations-Fluid extract: Dose, $\frac{1}{2}$-I drachm. Corydalin: Dose, 2 grains.

Distinctive character-Tubers tawny yellow, about $\frac{1}{4}$ inch in diameter, globose-depressed, with a scar on both the depressed sides, internally horny, or somewhat mealy as well. Taste, bitter. Inodorous. 
Syn.-Curcuma, Curcuma rotunda, Linn., Amomum Curcuma, Jacq.

\section{Part used-Rhizome.}

Action-Carminative, stimulating. Seldom used in medicine; in pharmacy it is employed as a colouring agent, and in cookery both as colour and seasoning. It forms a part of most curry powders, and enters into many cattle condiments.

Distinctive character-Turmeric occurs in commerce in several varieties. The Madras kind is sold, both round and long pieces. The round pieces, or bulbs, are the large central rhizome, about the size of a pigeon's egg, and are more or less pyriform, and marked with transverse ridges or leaf scars, and the long are the lateral rhizomes. Both are yellowish brown internally, with a short fracture. The Madras kind is preferred for flavouring purposes. The Bengal kind occurs in smaller, cylindrical pieces, greyish externally, and about $\frac{1}{2}$ inch in diameter, and dark brownish yellow internally, with a resinous fracture. It is preferred for dyeing purposes. Taste, aromatic. Odour, characteristic.

TURPETH.

Ipomœa Turpethum, R. Br. N.O. Convolvulacea.

Syn.-Turpeth Root.

Part used-Root.

Action-Cathartic, purgative. Used in India for similar purposes as Jalap, which it resembles closely in its action. 


\section{UNICORN ROOT, FALSE.}

Chamaellirium luteum, A. Gray.

N.O. Liliaced.

Syn. - Starwort, Helonias, Helonias dioica, Pursh., Helonias lutea, Ker-Gawl., Chamalirium Carolinianum, Willd.

\section{Part used-Root.}

Action-Tonic, diuretic. Acts as a general tonic in dyspepsia and in weakness of the reproductive organs. Also given in spermatorrhœa.

Preparations-Fluid extract: Dose, $\frac{1}{2}-\mathrm{I}$ drachm. Helonin: Dose, 2-4 grains.

Distinctive character-Rhizome about I inch long and $\frac{1}{1}$ inch thick, nearly cylindrical, ringed transversely, greyish brown, with a few stem scars on the upper, and wiry rootlets on the lower side. Fracture horny, wood bundles numerous in the centre. Taste, bitter. Inodorous.

UNICORN ROOT, TRUE. Aletris farinosa, Linn. N.O. Hamodoracea.

Syn. - Blazing Star.

Part used-Root.

Action-Tonic and stomachic. As a female tonic it has but few equals and may be given in all cases of debility. Small doses only should be given, as large ones produce nausea and giddiness.

Preparations-Powdered root: Dose, 4-Io grains. Fluid extract: Dose, $\frac{1}{2}-1$ drachm. Aletrin: Dose, $\frac{1}{2}-2$ grains.

Distinctive character-Rhizome brownish grey, flattened, and tufted on the upper side with leaf bases, 
convex, with numerous wiry rootlets on the lower side, about $\mathrm{I} \frac{1}{4}$ inch long and $\frac{1}{8}$ inch thick, indistinctly jointed. Fracture mealy, white, somewhat fibrous. Taste, bitter. Inodorous.

UVA = URSI.

Arctostaphylos Uva"ursi, Spreng. N.O. Evicacea.

Syn.-Bearberry.

Part used-Leaves.

Action-Mucilaginous, astringent, diuretic. Has a specific action on the urinary organs and is especially useful in cases of gravel, ulceration of kidneys or bladder, catarrh, gleet, leucorrhœea and menorrhagia. The infusion of I ounce to a pint of boiling water is taken in wineglassful doses three to four times a day.

Preparations-Fluid extract: Dose, $\frac{1}{2}-\mathrm{I}$ drachm. Infusion B.P.: Dose, $\frac{1}{2}-1$ ounce.

Distinctive character-Leaves leathery, obovate or oblanceolate, rounded at the apex, dark green and shining above, and tessellated by sunken veinlets, paler beneath and reticulated, with dark veinlets; margin entire and reflexed, about $\frac{3}{4}-\mathrm{I}$ inch long and $\frac{1}{4}-\frac{3}{8}$ inch broad. Taste, astringent. Odour, faintly tea-like.

VALERIAN.

Valeriana officinalis, Linn. N.O. Valevianacee.

Syn.-Great Wild Valerian.

Part used-Root.

Action-Anodyne, antispasmodic, nervine. May be given in all cases of nervous debility and irritation, also in hysterical affections. It allays pain and promotes sleep. Is strongly nervine without any narcotic effects, and enters into various herbal nervine and anti- 
spasmodic compounds. The infusion of $I$ ounce to pint of boiling water is taken in wineglassful doses.

Preparations-Fluid extract : Dose, $\frac{1}{2}-\mathrm{I}$ drachm. Solid extract: Dose, 5-10 grains. Tincture B.P. and U.S.P., r 885 : Dose, I-2 drachms. Ammoniated tincture B.P. and U.S.P., I898: Dose, $\frac{1}{2}$-I drachm.

Distinctive character-The root is at once distinguished by its strong and disagreeable odour. It consists of a short rootstock, about $\frac{3}{4}$ inch long and $\frac{1}{2}$ inch in diameter, with numerous short lateral branches, and rootlets 3 or 4 inches long, the crown often showing the leaf scales of the stem base. The transverse section is horny with a very narrow woody ring, and is of a pale grey-brown colour. Old roots are often hollow. Taste, sweetish, bitter. Odour, characteristic.

\section{VERNAL GRASS, SWEET.}

Anthoxanthum odoratum, Linn. N.O. Graminacea.

Part used-Flowers.

Action-It has been used in hay fever, internally in the form of a tincture, and externally as a snuff.

Preparation-Tincture: Dose, 5-Io drops.

Distinctive character-Flowers in dense spikes, tapering at both ends, about $\mathrm{r} \frac{1}{2}$ inch long and $\frac{1}{8}$ inch wide. It is distinguished from the allied genera by having only two stamens in the flowers, and by its aromatic hay-like taste.

VERVAIN.

Verbena officinalis, Linn. N.O. Verbenacea.

Syn.-Verbena hastata, Linn.

Part used-Herb.

Action-Nervine, tonic, emetic, sudorific. May be employed with advantage in the early stages of fevers, 
colds, \&c., and in the treatment of fits, convulsions, and nervous disorders. The sweetened infusion of I ounce to a pint of boiling water, is a good remedy for coughs, colds, \&c., when taken frequently in wineglassful doses.

Preparation-Fluid extract: Dose, $\frac{1}{2}-\mathrm{I}$ drachm.

Distinctive character-Stem I-2 feet high, quadrangular. Leaves distant and opposite, pinnately-lobed, serrate, rough. Flowers small, pinkish blue, twolipped, with didynamous stamens and an entire fourseeded ovary. Taste, very bitter. Odour, when rubbed, slightly aromatic.

VIOLET.

Viola odorata, Linn. N.O. Violacea.

Syn.-Blue Violet, Sweet Violet.

Parts used-Leaves, flowers.

Action-Antiseptic, expectorant. Violet leaves contain certain glucosidal principles, not yet fully investigated, but of distinct antiseptic properties. - It has lately been recommended and used with benefit to allay pain in cancerous growths-some even say to cure cancer. The fresh leaves are put in boiling water-a handful to a pint-covered over and set aside for 24 hours. The infusion is then applied by means of lint to the affected parts; it may also be taken internally at the same time. Or a poultice may be made and used in similar manner. The flowers possess expectorant properties, and have long been used in syrup form for coughs, colds, \&c.

Distinctive character-The leaves are cordateovate, obtuse, with long stalks bearing deflexed hairs. Flowers blue, with a hooked stigma, and a short spur inflated at the end, and channelled above. In a blue variety of Viola tricolor, sometimes preferred for colouring purposes, the stigma is inflated, not hooked. The 
flowers of $V$. calcarata, with oblong sepals and a corolla spur twice as long as the sepals, are also sold under this name.

WAFER ASH.

Ptelea trifoliata, Linn. N.O. Rutacea.

Syn.-Wingseed, Hop Tree, Shrubby Trefoil, Ptelea, Swamp Dogwood.

Part used-Rootbark.

Action-Tonic, antiperiodic, stomachic. In all cases of debility, and during intermittent and remittent febrile diseases, where a tonic is indicated, this drug can be employed with benefit. It has a soothing influence upon the mucous membrane and promotes appetite, being tolerated when other tonics cannot be retained. The powdered bark is given in doses of 10-30 grains. The infusion is taken in tablespoonful doses three to four times a day.

Distinctive character-The rootbark occurs in quilled or curved pieces, about $1 \frac{1}{2}-3$ inches long and $\frac{1}{2} \cdot \frac{3}{4}$ inch in diameter and $\frac{1}{8}-\frac{3}{4}$ inch thick, transversely wrinkled, with a whitish brown or pale buff exfoliating surface of thin, papery layers, the inner surface nearly smooth, with faintly projecting medullary rays. Transverse fracture short, yellowish white, the papery layer pale buff. Taste, bitter. Odour, none.

WAHOO.

Euonymus atropurpureus, Jacq.

N.O. Celastracea.

Syn.-Indian Arrowwood, Burning Bush, Spindle Tree.

Parts used-Rootbark, bark.

Action-Tonic, alterative, cholagogue, la xative. Valuable in liver disorders, especially those following or 
accompanied with fever. For constipation due to inactivity of liver it may be given with every confidence, especially as its action is mild and non-irritant. The concentration "Euonymin" is generally given in pill form and in combination with other tonics, laxatives, \&c.

Preparations-Fluid extract: Dose, $\frac{1}{2}$-I drachm. Powdered root: Dose, $\frac{1}{2}-1$ drachm. Euonymin: Dose, I-4 grains. Powdered extract U.S.P.: Dose, 2 grains. Powdered extract B.P.: Dose, 2 grains.

Distinctive character-The rootbark occurs in quilled or curved pieces about $\frac{1}{12}$ inch thick, ash grey, with blackish ridges or patches, outer surface whitish or slightly tawny. Fracture friable, smooth, whitish, the inner layer appearing tangentially striated. Taste, sweetish, bitter, and acrid. Nearly inodorous. The stembark is in longer quills, with a smooth outer surface with lichens usually present on it, and a greenish layer under the epidermis.

WAKE ROBIN.

Arum triphyllum, Linn. N.O. Aracea.

Syn.-Wild Turnip, Indian Turnip, Dragon Root, Jack-in-the-pulpit, Arisaema triphyllum, Schott.

Part used-Root.

Action-Expectorant, diaphoretic. Recommended in croup, whooping cough, cough, bronchitis, laryngitis. pains in chest, \&c. Also useful in flatulence, asthma, and colic.

Preparation-Powdered root: Dose, 10-30 grains.

Distinctive character-About I-2 inches broad, depressed globular, with a ring of simple rootlets above, the surface wrinkled below, brown-grey, internally white and mealy, with scattered wood-bundles. In slices $I-2$ inches in diameter and $\frac{1}{4}$ inch thick, brownish white at the margins, the transverse surfaces white, 
starchy, with numerous pale brown dots indicating the scattered wood-bundles. Taste, burning and acrid. Odour, none.

\section{WALNUT.}

Parts used-Bark, leaves.
Juglans nigra, Linn.

N.O. Juglandacea.

Action-Alterative, laxative, detergent. Used in herpes, eczema, scrofula, and syphilis. The infusion of I ounce of bark or leaves to a pint of boiling water is taken in wineglassful doses. Externally this is also used as an application to skin eruptions, ulcers, \&c.

Preparation-Fluid extract, leaves: Dose, I-2 drachms.

Distinctive character-The leaflets vary in size on the same leaf, which is composed of seven to nine leaflets. They average $2 \frac{1}{4}-4$ inches in length and I-I $\frac{1}{2}$ inch wide, rather paler below, parchment-like when dry, leafstalks brown. Taste, bitter and astringent. Odour, aromatic and characteristic. By long keeping the leaves become brown and lose their aroma.

The bark occurs in quilled or curved pieces 3.6 inches long or more, and $\frac{3}{4}-\mathrm{I} \frac{1}{2}$ inch broad, dull blackish brown, with traces of a thin whitish epidermal layer, tough and fibrous, and somewhat mealy; the inner fibres tough and flattened, those in the outer mealy portion white and silky. Taste, bitter and astringent. Odour, none.

WATER BETONY. Scrophularia aquatica, Linn. N.O. Scrophulariacea.

Syn.-Brownwort, Bishop's Leaves, Betonica aquatica.

Part used-Leaves.

Action-Vulnerary, detergent. Used externally as poultice for ulcers, sores, and wounds, or boiled in lard as an ointment. 
Distinctive character-Stem and leafstalks winged, leaves cordate-oblong, obtuse, crenate-serrate, bracts linear, blunt. Flowers greenish purple, small, with two long and two short stamens, and a roundish, kidneyshaped staminode; ovary two-celled, with numerous seeds. Taste, bitterish. Odour, none.

\section{WATER DOCK.}

Syn.-Red Dock.

Part used-Root.
Rumex aquaticus, Linn. N.O. Polygonacea.

Action-Alterative, deobstruent, detergent. Used for cleansing ulcers in affections of the mouth, \&c. As a powder it has cleansing and detergent effects upon the teeth. Internally the dose of the infusion is a wineglassful.

Preparation-Fluid extract: Dose, $\frac{1}{2}-\mathrm{I}$ drachm.

Distinctive character-In vertical slices, taken through the top-shaped rootstock, the outer surface blackish or dark brown, with the remains of a few branches, and transverse rings of scars of rootlets. The transverse section shows a porous bark, and a large pith, with honeycomb-like cells, and a short zone of woody bundles, with porous medullary rays between them. Taste, astringent and somewhat sweet. Odour, none.

WATER DROPWORT. Oenanthe crocata, Linn. N.O. Umbellifera.

Syn.-Hemlock Water Dropwort, Water Lovage, Hemlock Dropwort, Dead Tongue.

Part used-Root.

Action-Narcotic, poisonous. This is an exceedingly poisonous plant, producing severe gastro-intestinal disturbances and convulsions. A tincture made with 2 ounces in a pint of diluted alcohol has been used with 
benefit in epilepsy resulting from injury, the dose being I-5 drops, administered with great caution.

Distinctive character-The root is white, or yellowish when dried, spindle-shaped, containing a milky juice which, in the fresh root, exudes in scattered drops that quickly turn orange when the root is broken. Exceedingly poisonous, and should not be used except under a doctor's order.

\section{WATER FENNEL.}

Oenanthe Phellandrium, Lamk. N.O. Umbellifera.

Syn.-Phellandrium aquaticum, Linn.

Part used-Fruit.

Action-Expectorant, alterative, diuretic. In chronic affections of the air passages, such as asthma, laryngitis, catarrh, \&c., this is considered to have a beneficial effect. The powder may be given in doses of 4-5 grains. cautiously administered, as large doses produce dizziness, pains in head, and other undesirable symptoms, Dr. Turnbull, of Liverpool, recommends it highly in bronchitis to relieve cough, ease expectoration, and produce sleep.

Distinctive character-The fruit is oblong, about $\frac{1}{5}$ inch long and $\frac{1}{12}$ inch in diameter, tapering a little towards the apex, and crowned with four minute, subulate teeth. There are four vittae (oil cells) on the convex surface, and two on the flat surface of each half fruit. Taste, acrid. Odour, strong, a romatic, and characteristic.

\section{WATER GERMANDER.}

Teucrium Scordium, Linn. N.O. Labiata.

Part used-Herb.

Action-Antiseptic, diaphoretic, stimulant. Will be found an excellent remedy in all inflammatory diseases. 
The infusion of I ounce of herb in a pint of boiling water is taken in wineglassful doses.

Preparation-Fluid extract: Dose, $\frac{1}{2}-\mathrm{I}$ drachm.

Distinctive character-Stem velvety. Leaves opposite, sessile, oval-oblong, $\frac{3}{4}$ inch long and $\frac{1}{5}$ inch broad, narrowed at the base, coarsely serrate at the margin, and softly hairy on both sides. Taste, bitter. The fresh leaves, when rubbed, have a penetrating alliaceous odour.

WATER PLANTAIN.

Syn.-Mad-Dog Weed.

\section{Part used-Leaves.}

Action-Diuretic, diaphoretic. An excellent remedy in gravel and other urinary and kidney diseases, where there is irritation and uneasiness in passing water, pains in the loins, \&c. The powdered leaves are given in doses of $\mathrm{I}-2$ drachms, or taken in an infusion of $\mathrm{I}$ ounce to a pint of boiling water in teacupful doses three or four times a day.

Distinctive character - The leaves are greyish green, cordate-ovate, or lanceolate, with prominent veins on long stalks. Taste, acrid. Odour, none.

\section{WHITE POND LILY, AMERICAN.}

Nymphra odorata, Soland. N.O. Nympheacea.

Syn.-Water Nymph, Water Cabbage.

Part used-Root.

Action-Antiseptic, astringent, demulcent. Will be found of service in bowel complaints, where an astrin- 
gent is needed. A decoction of I ounce of root boiled in a pint of water for twenty minutes is taken internally in wineglassful doses. For external application the decoction can be used as an excellent lotion for bad legs and sores generally. As an injection in leucorrhœa, fluor albus, and gleet, it is very useful. In putrid sore throat it may be used as a gargle, and it is a good wash for sore eyes, ophthalmia, \&c. The powder is often used as a poultice, when it should be combined with equal parts of crushed Linseed or powdered Slippery Elm.

\section{Preparation-Fluid extract: Dose, $\frac{1}{2}$-I drachm.}

Distinctive character-The root in pieces about 2 inches in diameter, with circular leaf scars on the upper, and remains of rootlets on the lower side; externally brown, internally greyish white, spongy, with scattered wood bundles. Taste, mucilaginous, astringent. Inodorous. The English White Water Lily is N. alba, Linn.

WILD CARROT.

Syn.-Bird's Nest.

Part used-Herb.

Action-Diuretic, deobstruent, stimulant. An active and valuable remedy in the treatment of dropsy, retention of urine, gravel, and affections of the bladder. The infusion of I ounce in a pint of boiling water is taken in wineglassful doses.

Preparation-Fluid extract: Dose, $\frac{1}{2}-\mathrm{I}$ drachm.

Distinctive character-Leaves oblong, or obovateoblong, bipinnate, with acute segments, the whole plant hairy. In taste and odour it resembles the garden carrot, but the root is small and white, not large. The umbel of white flowers has generally one central crimson flower, and the fruit is margined with prickles which are tipped with one to three minute recurved bristles. 
WILD CHERRY.

Prunus serotina, Ehrh. N.O. Rosacea.

Syn.-Virginian Prune, Cerasus serotina, Lois.

Part used-Bark.

Action-Astringent, tonic, pectoral, sedative. Used as a tonic in convalescence from fevers, \&c. Also as a valuable remedy in catarrhal affections; given in consumption, nervous cough, whooping cough, and dyspepsia.

Preparations-Fluid extract: Dose, $\frac{1}{2}$-I drachm. Syrup B.P. and U.S.P.: Dose, $\mathrm{I}-4$ drachms. Tincture B.P.: Dose, $\frac{1}{2}-1$ drachm. Infusion U.S.P.: Dose, 2 ounces. Prunin: Dose, I-3 grains.

Distinctive character--The bark occurs in curved or flat pieces $\frac{1}{12}$ inch or more thick, externally smooth, greenish brown or yellowish brown and glossy; or if from older trees rust-brown, uneven and deprived of most of the corky layer. Fracture short, granular, radiately striate, under surface often porous, with a network of fibres. When soaked in water it gives off a bitter-almond odour. Taste, bitter, astringent, and aromatic.

WILD INDIGO.

Baptisia tinctoria, R. Br. N.O. Leguminosa.

Syn. - Baptisia, Indigoweed, Sophora tinctoria, Linn., Podalyria tinctoria, Michx.

Parts used-Root, leaves.

Action-Antiseptic, stimulant, purgative, emmenagogue. In small doses is a mild laxative; in large, a powerful cathartic. Used in rheumatism, scarlatina, \&c., and as an antiseptic injection in foul discharges. A decoction of $\mathrm{I}$ ounce in a quart of water boiled down to a pint is taken in tablespoonful doses. An ointment 
made from I part of fluid extract to 8 parts of simple ointment is applied to inflamed tumours and ulcers.

Preparations-Fluid extract: Dose, $\frac{1}{1}-\frac{1}{2}$ drachm. Baptisin: Dose, I-3 grains.

Distinctive character-Crown of the root with knotty branches and few little-branched roots about 20 inches long and $\frac{1}{4}-\frac{1}{2}$ inch thick, furrowed longitudinally, becoming warty and scaly externally. Fracture tough and fibrous. Bark brown, rather thick, with tough bast fibres in radial lines. Wood whitish, with concentric lines, finely porous, medullary rays indistinct. Taste, bitterish, acrid, and disagreeable ; the wood, tasteless.

WILD MINT.

Mentha sativa, Linn. N.O. Labiata.

Syn,-Marsh Mint, Mentha aquatica, Linn.

Part used-Herb.

Action-Emetic, stimulant, astringent. Used in diarrhœa and in difficult menstruation. The infusion of I ounce to a pint of boiling water is taken in wineglassful doses.

Distinctive character-Leaves opposite, stalked, ovate, acute, serrate, subcordate below, hairy. Flowers forming a terminal globose head and a few axillary clusters. Taste, aromatic. Odour, characteristic.

WILD YAM.

Dioscorea villosa, Linn. N.O. Dioscoracee.

Syn.-Dioscorea, Colic Root, Rheumatism Root.

Part used-Root.

Action-Antibilious, antispasmodic, diaphoretic. Is valuable in all forms of colic, abdominal and intestinal 
irritation, \&c., in spasms, spasmodic asthma, vomiting, and hepatic congestion. A decoction of I ounce of root in a pint of water may be taken in tablespoonful doses until relieved. Large doses may produce emesis.

Preparations-Fluid extract: Dose, $\frac{1}{2}-I$ drachm. Dioscorein: Dose, $\frac{1}{2}-4$ grains.

Distinctive character-Tuber cylindrical compressed, branched at intervals of about 2 inches, and curved, about 4-6 inches long, and $\frac{1}{2}-\frac{3}{4}$ inch thick, pale brown externally, with sunk stem scars on the upper and remains of rootlets below. Fracture short, internally hard, white, with yellowish wood bundles. Taste, insipid, afterwards acrid. Inodorous.

WILLOW, BLACK.

Syn.-Pussy Willow.

Parts used-Bark, berries.

Action-Anaphrodisiac, sexual sedative, tonic. Is highly recommended and largely used in the treatment of spermatorrhœa, nocturnal emissions, \&c. Also relieves ovarian pain. The infusion of I ounce of bark to a pint of boiling water is used in wineglassful doses. A poultice made by simmering the powdered bark in cream is unrivalled in gangrene and indolent ulcers, \&c.

Preparation-Fluid extract: Dose, $\frac{1}{2}-\mathrm{I}$ drachm.

Distinctive character-In quilled pieces, 2-6 or more inches long and about $\frac{3}{4}$ inch broad, blackish grey externally, with numerous dark brown, round lenticels, inner surface pale buff. Transverse section pale buff, rough, with flat pointed fibres. Taste, bitter, astringent. Odour, none. 
WILLOW, WHITE.

Syn.-European Willow.

Part used-Bark.

Action-Tonic, antiperiodic, astringent. Has been used with benefit in febrile diseases of rheumatic or gouty origin, also in diarrhœa and dysentery. The usual form of administration is the decoction, given in wineglassful doses four to five times a day.

Distinctive character-In quills or fragments of varying length, $\frac{1}{24}-\frac{1}{12}$ inch thick, somewhat glossy, brownish, striated longitudinally, with ellipsoid leaf scars. Inner surface cinnamon brown, finely striated. Fracture short, slightly laminated. Taste, bitter. Inodorous.

WINTER'S BARK.

Drimys Winteri, Forst.

N.O. Magnoliacea.

Syn.-Wintera, Winter's Cinnamom, True Winter's Bark, Wintera aromatica, Murr.

Part used-Bark.

Action-Stimulant, aromatic, stomachic. This bark has been highly recommended in indigestion, flatulence, colic, \&c., and also as an antiscorbutic. The powdered bark is given in doses of 30 grains. An infusion made from I ounce of bark in a pint of boiling water is given in wineglassful doses.

Distinctive character-Now very rare in commerce, but sometimes imported under the name of pepper bark. In short pieces $\frac{1}{4}-\frac{1}{3}$ inch in thickness, and 2-3 inches long, dark brown throughout. Fracture short and granular, showing pale medullary rays in the bark, which project on the inner surface, giving it a striated appearance. Taste, very pungent. Odour, feeble. 
Syn.-Alkekengi, Strawberry Tomato.

Part used-Berries.

Action-Diuretic, febrifuge. Has been employed with success in intermittent fevers, also in urinary disorders caused by rheumatism and gout.

Distinctive character-The dried berries are dull red, about $\frac{1}{3}-\frac{1}{2}$ inch in diameter, globular, two-celled, containing numerous whitish, ovoid, flattened seeds. The red inflated calyx, about I inch in diameter, is sometimes left attached to the berries. Taste, sweet and bitterish. Odour, none. The plant sold in pots as Winter Cherry is Solamum pseudo-capsicum.

WINTERGREEN. Gaultheria procumbens, Linn. N.O. Evicacea.

Syn.-Teaberry.

Part used-Leaves.

Action-Aromatic, astringent, stimulant. A very valuable remedy in the treatment of rheumatism, for which it is often used, especially in combination with other herbal agents. May be employed in diarrhœa, and as an infants' carminative. The infusion of $\mathrm{I}$ ounce in a pint of boiling water is taken in wineglassful doses.

Preparations-Fluid extract: Dose, $\frac{1}{2}-\mathrm{I}$ drachm. Oil : Dose, 5-15 drops. Spirit U.S.P.: Dose, 30 drops.

Distinctive character-The leaves are obovate or broadly elliptical, short-stalked, faintly serrate at the margin, leathery, glossy green above, paler beneath. Taste, astringent and aromatic. Odour, that of methylsalicylate. 
WITCH HAZEL.

Syn.-Spotted Alder.
Hamamelis Virginiana, Linn.

N.O. Hamamelidacea.

Parts used-Bark, leaves.

Action-Astringent, tonic, sedative. Most valuable in checking internal and external hæmorrhages, also in the treatment of piles. A decoction made from the bark or leaves makes an excellent injection for bleeding piles. An ointment made by adding I part fluid extract bark to 9 parts simple ointment is also used as a local application. The distilled extract from the fresh leaves and young twigs forms an excellent household remedy for internal or external use. For varicose veins it should be applied on a lint bandage, kept constantly moist. The concentration "Hamamelin" is used for piles mostly in form of suppositories.

Preparations-Fluid extract, bark: Dose, $\frac{1}{2}$-I drachm. Fluid extract B.P., leaves: Dose, I5-30 drops. Distilled extract: Dose, $\frac{1}{2}-2$ drachms. Ointment B.P. Hamamelin: Dose, I-3 grains. Water U.S.P.: Dose, 2 drachms. Tincture B.P.: Dose, $\frac{1}{2}-\mathrm{I}$ drachm.

Distinctive character-Bark in quilled pieces about $\frac{1}{16}$ inch thick, from 2.4 or more inches long, the outer surface greyish, scaly, with transverse lenticels, pinkish brown, the inner surface striated longitudinally. Fracture fibrous and laminated. Taste, astringent. Odour, feeble. The leaves are broadly obovate, usually 3 or 5 inches long, and about $2-2 \frac{1}{2}$ inches broad, the margins serrate-dentate, feather-veined, the erect veins prominent below, each ending in a tooth. The hairs, when remaining on the dried, rather brittle, leaves, are stellate.

WOOD BETONY.

Stachys Betonica, Benth. N.O. Labiata.

Syn.-Bishopswort, Betonica oficinalis, Linn.

Part used-Herb.

Action-Aromatic, astringent, alterative. Used as a tonic in dyspepsia and as an alterative in rheumatism, 
scrofula, and impurities of the blood. Is generally combined with other remedies. The dose of the infusion of $I$ ounce to a pint of boiling water is a wineglassful taken frequently.

Preparation-Fluid extract: Dose, $\frac{1}{2}$-I drachm.

Distinctive character-Stem furnished with few distant pairs of rough, hairy, oblong leaves, 2-3 inches long and about $\frac{3}{4}-I$ inch broad, crenate at the margins, the leaves mostly radical. Flowers purplish, labiate, arranged in a terminal oval spike interrupted below, the calyx smooth.

WOODRUFF.

Asperula odorata, Linn. N.O. Rubiacea.

Syn.-Woodroof, Waldmeister Tea.

Part used-Herb.

Action-Diuretic, tonic. Useful for removing biliary obstructions of liver, \&c., and is strengthening to the stomach.

Distinctive character-Herb about 6-8 inches high, with a slender, quadrangular, brittle stem, and whorls of usually eight narrowly elliptic, rather rigid leaves about $I$ inch long and $I \frac{1}{4}$ inch broad, entire at the margins, and tipped with a sharp point. Taste, like coumarine. Odour, when dried, like hay.

WOOD SAGE.

Syn.-Garlic Sage.

Part used-Herb.

Action-Diaphoretic, astringent, emmenagogue, tonic. Used in fevers, colds, inflammations, and in obstructed
Teucrium Scorodonia, Linn. N.O. Labiata. 
menstruation. The infusion of I ounce in a pint of boiling water is taken warm in wineglassful doses.

Preparation-Fluid extract: Dose, $\frac{1}{2}-\mathrm{I}$ drachm.

Distinctive character-Stems obtusely quadrangular. Leaves opposite, stalked, ovate, with a cordate base, obtuse, crenate-serrate, the upper surface reticulated with prominent veinlets beneath; about $1 \frac{1}{2}$ inch long and $\frac{3}{8}$ inch broad. Taste, bitter, resembling that of hops. Odour, slightly aromatic.

WOOD-SORREL.

Syn.-Common Wood-Sorrel.

Part used-Herb.

Action-Diuretic, refrigerant. Reputed of value in febrile diseases, urinary affections, catarrh, gonorrhœa, and hæmorrhages. The herb may be infused with water or boiled in milk and administered freely, although excess should be guarded against.

Distinctive character-Leaves trifoliate, stalked, the leaflets broadly obcordate and emarginate, reflexed when dry, the leafstalk slender, often reddish toward the base. Flowers white, bell-shaped, with delicate purplish veins. Taste, pleasantly acid. Odour, none.

\section{WORMSEED.}

Chenopodium anthelminticum, Bert. N.O. Chenopodiacea.

Syn.-American Wormseed, Chenopodium ambrosioides, Linn.

\section{Part used-Seed.}

Action-Anthelmintic, antispasmodic. Chiefly used to expel intestinal worms. It should be given at bed- 
time and in the morning before food, for two or three days, followed by some cathartic.

Preparations-Fluid extract: Dose, $\frac{1}{2}-1$ drachm. Oil : Dose, 2-10 drops.

Distinctive character-Fruit depressed globular, about $\frac{1}{12}$ inch in diameter, greenish or brown, glandular. The single seed is glossy, black, lenticular, with an obtuse edge, the albumen containing a curved embryo. Taste, acrid, astringent, and turpentiny. Odour, camphoraceous and turpentiny. It is known in New Zealand as Californian Spearmint.

WORMSEED, LEVANT.

Artemisia Cina, Berg. N.O. Composita.

Syn.-Santonica, Semen cinae, Semen sanctum, Semen contra, Semen santonici, Artemisia Levcheana, Kar. and Kir., Artemisia mavitima, var. panciflora, Web., Avtemisia maritima, var. Stechnanniana, Bess., A. chamamelifolia, Vill.

Part used-Seeds.

Action-Vermifuge. In substance the seeds are used in domestic practice combined with honey or treacle. They contain "Santonin" and this is official in the B.P. 1898 , and is given in doses of $2-5$ grains. The dose of the seeds is from 10.30 grains night and morning.

\section{Preparation-Santonin lozenges B.P.}

Distinctive character-This drug consists of minute flowerheads containing three to five minute tubular flowers, without pappus. The flowerheads are about $\frac{1}{8}$ inch long and $\frac{1}{18}$ inch in diameter, greenish yellow when fresh, brown when kept for some time; each has I8 oblong-obtuse scales closely overlapping each other and bearing minute yellow glands on their surface. Taste, bitter and aromatic. Odour, when rubbed, that of cineol. 
WORMWOOD.

Syn.-Old Woman.

Part used-Herb.

Action-Tonic, stomachic, febrifuge, anthelmintic. A good remedy for enfeebled digestion and debility. It may also be used to expel worms. The infusion of I ounce to a pint of boiling water is taken in wineglassful doses.

Preparation-Fluid extract: Dose, $\frac{1}{2}-\mathrm{I}$ drachm.

Distinctive character-Stem $2-2 \frac{1}{2}$ feet high, whitish like the leaves, with fine, silky, appressed hairs. Leaves about 3 inches long by $\mathrm{I} \frac{1}{2}$ inch broad, about three times pinnatifid, the leafstalks slightly winged at the margin, and the lobes linear and obtuse. The small, nearly-globular flowerheads are arranged in an erect leafy panicle, the leaves being reduced to three or even one linear segment. The flowers have a greenish yellow tint, and have no pappus. Taste, very bitter. Odour, characteristic, resembling that of thujone.

WOUNDWORT.

Stachys palustris, Linn.

N.O. Labiata.

Syn.-Allheal, Panay, Opopanewort, Clownswort, Downy Woundwort, Clown's Woundwort, Rusticum Vulna Herba.

\section{Part used-Herb.}

Action-Antiseptic, antispasmodic. It relieves gout, cramp, and pains in the joints, falling sickness and vertigo. The bruised leaves, applied to a wound, will stop bleeding and heal the wound. The fresh juice is made into a syrup and taken internally to stop hæmorrhages, dysentery, \&c.

Distinctive character-Leaves cordate-ovate, serrate, long-stalked, hairy. Stems square. Taste, astringent. Odour, unpleasant. 
Syn,-Milfoil, Thousand Weed, Nosebleed.

Part used-Herb.

Action-Diaphoretic, stimulant, tonic. Most useful in colds, obstructed perspiration, and the commencement of fevers. It opens the pores freely and purifies the blood. The infusion of $\mathrm{r}$ ounce to a pint of boiling water is taken in wineglassful doses, drunk warm, with a teaspoonful of Composition Essence added to each dose.

Preparation-Fluid extract: Dose, $\frac{1}{2}-\mathrm{r}$ drachm.

Distinctive character-Stem angular, rough. Leaves alternate, about 3-4 inches long and $\mathrm{I}$ inch broad, bipinnatifid, clasping the stem at the base; the segments very narrow, short, and linear acute. The whole plant more or less hairy with white, silky, appressed hairs. The flowerheads small, white, minutely daisy-like, in flattened-terminal corymbose cymes. Taste, insipid. Odour, feeble.

YELLOW DOCK.

Syn.-Curled Dock.
Rumex crispus, Linn. N.O. Polygonacea.

\section{Part used-Root.}

Action-Laxative, alterative, tonic. Can be freely used in rheumatism, skin diseases, bilious complaints, piles, bleeding of the lungs, \&c. A syrup may be made by boiling $\frac{1}{2}$ pound of crushed root in a pint of syrup and taken in teaspoonful doses. The dose of the infusion of I ounce of powdered root in a pint of boiling water is a wineglassful.

Preparations-Fluid extract: Dose, $\frac{1}{2}-\mathrm{I}$ drachm. Solid extract: Dose, 5-I5 grains. Rumin: Dose, 3 grains.

Distinctive character-The root occurs in short shrivelled pieces, about $\frac{3}{4}-\mathrm{r}$ inch long or more, brown, 
and more or less rough and wrinkled externally, showing on transverse section a yellowish brown, rather thick bark, surrounding a woody centre with concentric rings and a radiate structure. Taste, mucilaginous, bitterish. Odour, none.

YELLOW FLAG.

Iris Pseudacorus, Linn.

N.O. Iridacea.

Syn.-Yellow Iris, Flower-de-luce, Iris lutea, Iris aquatica.

Part used-Root.

Action-Astringent, cooling. It is reputed of value in dysmenorrhœa and leucorrhœa as an astringent lotion.

Distinctive character-Rhizome brownish externally, cylindrical, compressed, with transverse scars of fallen leaves, and scars of roots beneath, dark red internally. Taste, very acrid. Odour, none.

\section{YELLOW PARILLA.}

Menispermum Canadense, Linn. N.O. Menispermacea.

Syn.-Moonseed, Canadian Moonseed, Moonseed Sarsaparilla.

\section{Part used-Root.}

Action-Alterative, laxative, diaphoretic, tonic. A valuable alterative, considered to excel Sarsaparilla in treatment of scrofula, syphilis, blood disorders and cutaneous diseases generally. It also acts as a tonic 
and nervine, and may be given in all cases of debility and dyspepsia.

Preparations-Powdered root: Dose, $\frac{1}{2}$-I drachm. Fluid extract : Dose, $\frac{1}{2}-I$ drachm. Menispermin : Dose, I-4 grains.

Distinctive character-Root cylindrical, about $\frac{1}{4}$ inch thick, varying in length, finely wrinkled longitudinally, yellowish brown, with slender, branching, brittle rootlets, internally yellowish. Fracture tough, woody. Taste, bitter. Nearly inodorous.

\section{YERBA REUMA.}

Frankenia grandifolia, Cham. and Schlecht.

Syn.-Flux Herb.

N.O. Frankeniacea.

Part used-Herb.

Action-Mild astringent. Is of service in diarrhœa, dysentery, leucorrhœa, gonorrhœa, gleet, and catarrh. It may be applied locally as an injection.

Preparation-Fluid extract: Dose, $\frac{1}{2}-\mathrm{I}$ drachm.

Distinctive character-Stem slender, about $\frac{1}{16}$ inch in diameter, forked. Leaves opposite, about $\frac{1}{4}$ inch long and $\frac{1}{16}$ inch in diameter, linear, with stronglyrevolute margins, short hairy, as is also the stem. Taste, saline. Odour, none.

YERBA SANTA. Eriodictyon glutinosum, Benth. N.O. Eviodictyon Californicum, Hook, and Arn. Syn.-Eriodictyon, Mountain Balm, Bearsweed. Part used-Leaves.

Action-Aromatic, tonic, expectorant. Is highly recommended for bronchitis, asthma, consumption, and all similar catarrhal affections. To increase its effects 
in asthmatic complaints it is generally combined with Grindelia. An aromatic syrup of Yerba Santa is used to mask the taste of quinine.

Preparation-Fluid extract: Dose, $\frac{1}{2}-\mathrm{I}$ drachm.

Distinctive character-Leaves elliptic-lanceolate, about 2-4 inches long and $\frac{3}{4}$ inch broad, irregularly dentate at the margins. The upper surface is green and more or less varnished with resin, the lower surface reticulated and white with hairs. Taste, balsamic. Odour, aromatic and agreeable.

\section{ZEDOARY.}

Part used-Root.

Action-Aromatic, stimulant. It is chiefly employed as a carminative and stomachic, and acts in a manner very similar to ginger, only milder. The infusion of $\frac{1}{2}$ ounce to a pint of boiling water is given in tablespoonful doses as required.

Preparation-Fluid extract: Dose, ro-30 drops.

Distinctive character-The rhizome is usually sold in transverse slices about $\frac{3}{4}-1 \frac{1}{4}$ inch broad and $\frac{1}{4}$ inch thick. The outer surface is greyish, with a few circular striae and small spiny points of root bases. The transverse section is greyish white, hard, and horny. Taste, bitterish and camphoraceous. Odour, recalling cardamoms and ginger. 


\section{Forms \\ OF \\ Medicinal Preparations.}

\section{INFUSIONS.}

These preparations are generally made of ground or bruised roots, barks, herbs, or seeds, by pouring boiling water over the drug, letting it stand for half-an-hour, occasionally stirring, and finally straining the clear liquid carefully off. Sometimes cold water may be used, as in the case of a few bitters, such as Calumba, Quassia, \&c., when the ground drug will be found to yield its properties to water without heat. The usual quantity of drug to a pint of water is I ounce, but in a few cases where the drugs contain very active principles, less is sufficient. The dose of most infusions varies from a tablespoonful to a wineglassful or a teacupful.

\section{DECOCTIONS.}

As a rule decoctions are made by pouring cold water upon the cut, bruised, or ground drug, the mixture being boiled for twenty minutes to half-an-hour, cooled, and strained. Roots and Barks are generally treated in this manner, as they need longer subjection to heat to extract their virtues. Decoctions are generally made in a strength of I ounce to the pint, but, as the water boils away, it is best to use a pint and a half, and the decoction should then when finished measure I pint. The length of time depends upon the readiness with which the drug gives up its active principles to the liquid. The dose varies from two teaspoonfuls to a wineglassful or two. 


\section{FLUID EXTRACTS.}

These are most popular and convenient preparations, inasmuch as they, if properly made, are the most concentrated fluid forms in which vegetable drugs may be obtained. Fluid extracts are made in a variety of ways-evaporation by heat, in vacuo; cold percolation; high pressure, \&c.-each drug being treated in that manner by which its properties may be best extracted and held in concentrated solution. The strength of a Fluid Extract is I in I, or I ounce fluid represents I ounce of crude drug-for instance, I ounce of Fl. Ext. Golden Seal would represent the medicinal value of I ounce of Golden Seal Root. Fluid Extracts are daily becoming more popular, and, as they may be easily obtained, bid fair to rival the Tinctures and Preparations which have made Homœopathy so popular with those who seek an easy way of keeping a household stock of domestic remedies.

\section{SOLID EXTRACTS}

Are prepared by evaporating to the consistence of honey the fresh juices or strong infusions of vegetable drugs. They may also be manufactured by a spirituous process, in which case the alcohol is recovered by means of distillation from a strong tincture of the drug. Solid extracts are employed chiefly in the manufacture of pills, plasters, ointments, and in more recent years also for compressed tablets.

\section{TINCTURES}

Are spirituous preparations made with pure or diluted spirits of wine of drugs containing gummy, resinous, or volatile principles, or of any drugs rendered useless by the application of heat in any form, or of the great number of drugs which will not yield their properties to water alone, as their active principles are more readily extracted by spirit, better held in solution and preserved from deterioration.

Tinctures are generally made in a strength of I or 2 ounces of drug to the pint. The dose varies according to the active principles contained in the drug. 


\section{PILLS}

Are perhaps the best-known and most largely used form of medicines, chiefly because of their handy form and general convenience, and also because of their comparative tastelessness. Pills are for the most part composed of concentrated extracts and alkaloids in combination with active crude drugs. They may be obtained coated or uncoated, but the pearl-coated pill is the general favourite, as it is quite tasteless, and the coating, if properly made, is readily soluble in the stomach.

\section{TABLETS}

Are made by compressing drugs into a very small compass. It is claimed for them that they are superior to pills, because they are more easily administered and by reason of their rapid dissolution in the stomach are quicker in their action.

\section{CAPSULES}

Are gelatine containers of convenient sizes for swallowing and holding oils, balsams, \&c., which, because of their nauseous taste or smell, would be difficult to administer. Such drugs as Cod Liver Oil, Castor Oil, Copaiba, Sandalwood Oil, \&c., are largely given in this form, because objection is made to the remedies in their natural state.

\section{SUPPOSITORIES}

Are small cones made of some convenient and easily soluble base, and used where it is desired to apply medicines per rectum. They are invaluable in the treatment of internal piles, cancers, fistula, \&c. They are also made of nutrient ingredients, and passed into the bowels where patients are unable to take nourish-1 ment in the usual manner. 


\section{PESSARIES}

Are similar to Suppositories, but are made in a suitable shape to be used in female complaints, where it is desirable to apply remedies to the walls of the internal passages.

\section{CONCENTRATIONS}

Are a class of medicinal resins or resinoids obtained from medicinal drugs by precipitation from their alcoholic preparations, either by water, distillation, or other suitable means.

Those at present in use contain one or more, but not always all the therapeutic virtues of the drugs from which they are made, and in many cases are only powdered extracts.

\section{DOSES AND THEIR}

\section{Equivalents.}

I drop is equal to $\frac{1}{60}$ of a fluid drachm.

\section{I grain}

I drachm " $\frac{1}{60}$ of a solid drachm.

I tablespoonful ", $\frac{1}{2}$ of an ounce.

I wineglassful " I $\frac{1}{2}-2$ ounces or 3 to 4 tablespoonfuls.

I teacupful

I pint

I quart

I gallon
" $\frac{1}{8}$ of a gallon or 20 fluid ounces.

" $\frac{1}{4}$ of a gallon or 2 pints.

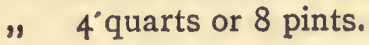

" 3-4 ounces or 6 to 8 tablespoonfuls. 


\section{Herbal Compounds (Continental).}

These are compounds used largely in France and Germany as household remedies. They are called "Species," and the liquid made, a "Tisane " or "Thee" (tea). They are prepared as ordinary infusions or decoctions ( $\mathrm{I}$ in 20 ), and the dose is a wineglassful frequently.

Anticatarrh.
$\left.\begin{array}{l}\text { Goosefoot } \\ \text { Rupturewort }\end{array}\right\}$ of each equal parts.

\section{Antilacteous.}

(Restraining the secretion of milk.)

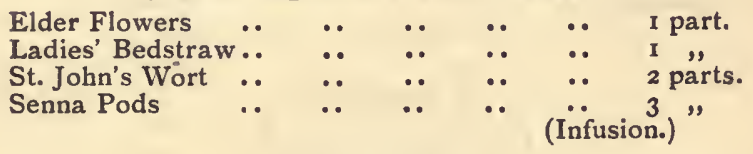

\section{Antispasmodic.}

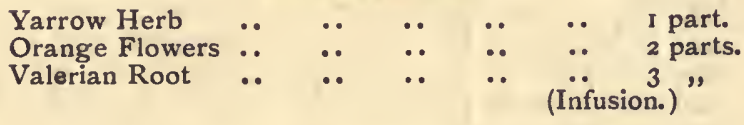

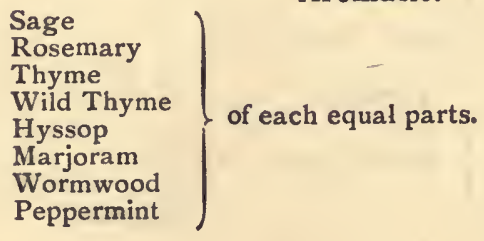

(Infusion.) 
$\left.\begin{array}{l}\text { Bistort } \\ \text { Tormentilla } \\ \text { Pomegranate }\end{array}\right\}$ of each equal parts.

\section{Astringent.}

(Decoction.)

\section{Bitter No. I.}

$\left.\begin{array}{l}\text { Germander } \\ \text { Centaury } \\ \text { Holy Thistle }\end{array}\right\}$ of each equal parts.

(Infusion.)

\section{Bitter No. 2.}

$\left.\begin{array}{l}\text { Holy Thistle } \\ \text { Germander } \\ \text { Centaury } \\ \text { Buckbean }\end{array}\right\}$ of each equal parts.

(Infusion.)

\section{Carminative.}

$\left.\begin{array}{l}\text { Aniseed } \\ \text { Fennel } \\ \text { Caraway } \\ \text { Coriander }\end{array}\right\}$ of each equal parts.

(Infusion.)

Cephalic.

(Nervine, for headache.)

Rosemary

Thyme

Wild Thyme

Wild Marjoram

Peppermint

of each equal parts.

Lavender Flowers

Rose Flowers

Marjoram

Rue

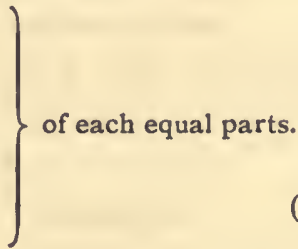

(Infusion.)

\section{Cooling.}

Melon Seed

Cucumber Seed

of each equal parts. Water Melon Seed

(Infusion.) 


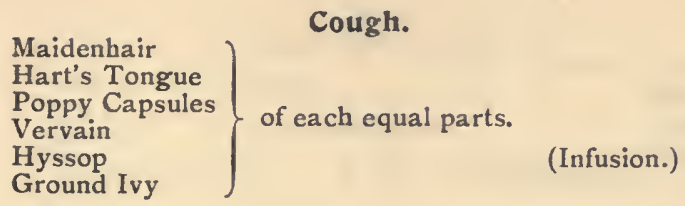

\section{Diaphoretic.}

Marshmallow Root

Liquorice

Orris

Ground Ivy

Aniseed

Coltsfoot Leaves ..

Red Poppy Flowers

Mullein

$$
\begin{aligned}
& \text {.. } \quad \text {.. } \quad \text {.. } \quad \text {. } \quad 8 \text { parts. } \\
& \begin{array}{lllll} 
& \ldots & \ldots & \ldots & 4
\end{array} \\
& \text {. }
\end{aligned}
$$

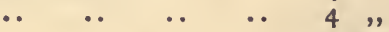

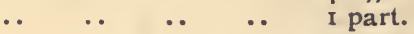

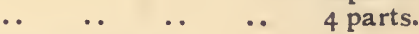

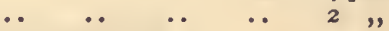

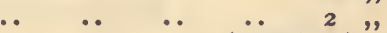

$$
\begin{aligned}
& \text { (Infusion.) }
\end{aligned}
$$

\section{Diaphoretic and Alterative.}

Sassafras IVood

Guaiacum

China Root

Sarsaparilla Root

(Espéces ou bois.) of each equal parts.

(Decoction.)

\section{Diaphoretic and Alterative.}

Sassafras Wood

Elder Flowers

$\left.\begin{array}{l}\begin{array}{l}\text { Elder Flowers } \\ \text { Red Poppy Flowers } \\ \text { Borage Leaves }\end{array}\end{array}\right\}$ of each equal parts.

\begin{tabular}{|c|c|c|c|c|c|c|}
\hline Guaiacum IVood & . & .. & $\cdots$ & $\cdot$ & . & I part. \\
\hline Burdock Root & . & . & .. & .. & .. & 2 parts. \\
\hline Elm Bark .. & .. & .. -10 & .. & .. & .. & I part. \\
\hline Bittersweet & . & . & .. & .. & & In.) \\
\hline
\end{tabular}

(Infusion.)

\section{Diaphoretic and Alterative.}

Diaphoretic, Smith's.

Sarsaparilla Root .. $\quad$.. $\quad$.. $\quad$.. $\quad$.. $\quad 4$ parts.

China Root.. $\quad$.. $\quad$.. $\quad$.. $\quad$.. $\quad$.. $\quad$ 2 ",

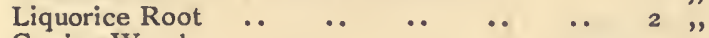

$\begin{array}{llllllll}\text { Guaiac Wood } & \ldots & \ldots & \ldots & \ldots & \ldots & 2 & \text {," }\end{array}$

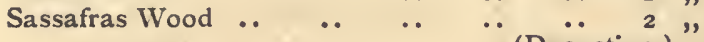

(Decoction.) 
Asparagus Root

Parsley

Celery

Fennel

Butcher's Broom

Diuretic, No. I.

\} of each equal parts.

(Decoction.)

Diuretic, No. 2.

Marshmallow Root

Asparagus

Liquorice

Stra wberry

Couchgrass

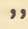

,

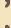

,

of each equal parts.

(Decoction.)

\section{Emmenagogue.}

Black Hellebore Root

Valerian

Wormwood

Wormwood Herb

Wormseed

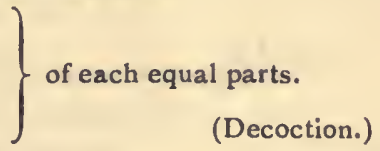

\section{Emollient.}

Marshmallow Flowers

Mallow

Mullein

Pellitory-of-the-wall

of each equal parts.

(Infusion.)

\section{Infants' Corrective.}

\begin{tabular}{|c|c|c|c|c|c|c|c|}
\hline \multicolumn{6}{|c|}{$\begin{array}{llllllll}\text { Fennel } & \text {. } & \text {. } & \text {. } & \text {.. } & \text {.. } & \text {.. } & 2 \text { parts. }\end{array}$} & \multicolumn{2}{|c|}{2 parts. } \\
\hline Aniseed $\quad .$. & .. & .. & .. & .. & .. & 2 & \\
\hline Couchgrass & .. & .. & .. & .. & -. & 5 & ", \\
\hline Polypody ... & •. & $\cdots$ & $\cdots$ & $\cdots$ & $\cdots$ & 5 & " \\
\hline Liquorice Root & .. & - & $\cdots$ & $\cdots$ & $\cdots$ & 10 & ", \\
\hline Figs .. $\quad .$. & . & .. & .. & . & .. & 10 & " \\
\hline $\begin{array}{l}\text { Johnsbread } \\
\text { Limeflowers }\end{array}$ & $\because$ & 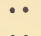 & 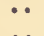 & $\because$ & $\cdots$ & 10 & " \\
\hline $\begin{array}{l}\text { Limeflowers } \\
\text { Hartshorn .. }\end{array}$ & $\ddot{0}$ & $\ddot{0}$ & $\ddot{0}$ & $\ddot{\cdots}$ & $\ddot{.}$ & 10 & $\ddot{\prime \prime}$ \\
\hline & & & & & (Infus & & \\
\hline
\end{tabular}

\section{Pectoral, Fruit.}

Dates (stoned) Jujubes (fruit)

Figs

Currants of each equal parts.

(Infusion.) 


\section{Pectoral, No. I (Flowers).}

Marshmallow Flowers

$\left.\begin{array}{ll}\text { Mallow } & , \\ \text { Coltsfoot } & , \\ \text { Violet } & , \\ \text { Mullein } & , \\ \text { Red Poppy } & , " \\ \text { Catsfoot } & ,\end{array}\right\}$ of each equal parts.

Pectoral, No. 2.

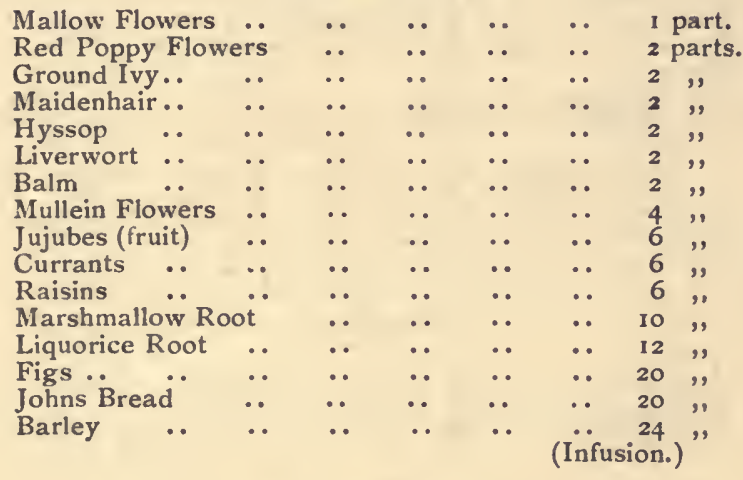

\section{Pectoral (Brust Thee), No. 3.}

Aniseed

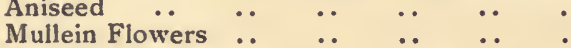

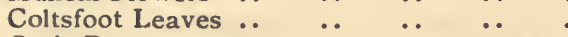

Orris Root .. .

Liquorice Root ..

Marshmallow Root

$$
\begin{aligned}
& \begin{array}{lllll} 
& \cdots & \cdots & \cdots &
\end{array}
\end{aligned}
$$

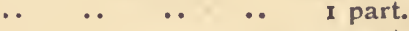

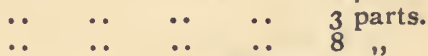

$$
\begin{aligned}
& \text { (Infusion.) }
\end{aligned}
$$

\section{Purgative (St. Germain).}

(Thé de santé.)

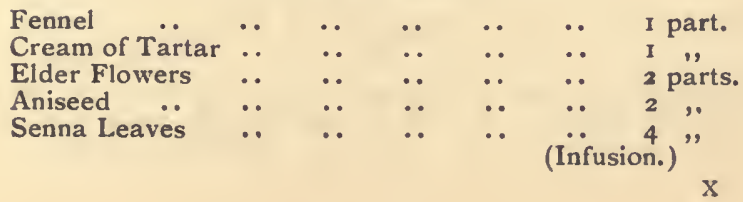


Swiss.

Wormwood

Wood Betony

Bugle

Mountain Mint

Water Germander

Hyssop

Ground Ivy

Yarrow

Marjoram

Periwinkle

Rosemary

Sanicle

Sage

Thyme

Wild Thyme

Germander

Vervain

Arnica Flowers

Catsfoot "

Coltsfoot ",

of each equal parts.

\section{Vermifuge.}

Tansy

Wormwood

Wormseed (Levant)

Chamomile

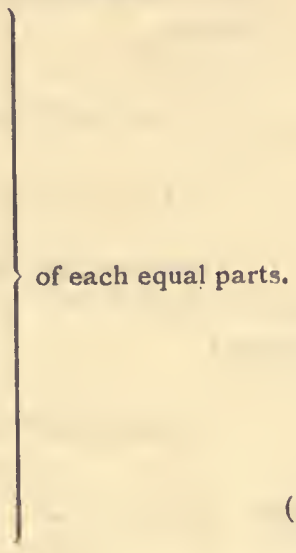

(Infusion.)

(Infusion.) 


\section{GLOSSARY OF BOTANICAL TERMS EMPLOYED IN THIS WORK.}

Achene-A one-seeded fruit, or part of a compound fruit, as $\mathrm{n}$ the Buttercup and Clematis, that does not open when ripe, and distinguishable from a seed by the remains of a style or stigma at the apex.

Acrid-Leaving a more or less burning sensation in the mouth and throat when chewed.

Acuminate-Tapering gradually to a fine point.

Albumen-The substance in the seed surrounding the germ or embryo when it is small. It is present in the Castor Oil seed (oily), in the Nux Vomica (horny), and in others fleshy or starchy, but it is not present in all seeds, those like the Bean and Almond having the nourishment stored up in their large seed-lobes.

Allaceous-Having an odour like garlic or onion.

Amplexicaul-The base of the leaf developed so as to clasp or surround the stem.

Annular or annulated-Applied to the root when constricted at intervals so as to form rings, as in Ipecacuanha.

Apetalous-Having no petals. When only one row of floral leaves is present, even if coloured, it is considered to be the caly $\mathbf{x}$, as in the Clematis, which is consequently apetalous.

Appressed or adpressed-A term applied to hairs when they lie close against the stem.

Arillus-A fieshy growth from the point where the seed is attached to the ovary, as in the Nutmeg, of which mace is the arillus.

Aromatic-Having a more or less agreeable odour.

Ascending-Applied to the stem when half-way between erect and prostrate.

Anthers-The part of the stamens containing the (usually powdery) pollen.

Awn-A tapering thread-like body, terminating the flower scales in grasses, or the seed in some of the Apocynacea, as in Strophanthus seed. 
Axillary-Proceeding from the axil or angle where the leaf or bract is attached to the stem.

Balsamic-Having a sweet odour like benzoin, usually due to the presence of compounds of benzoic or cinnamic acids.

Barbed-Furnished with sharp points bent backwards as in a fish-hook.

Berry - A soft fruit containing, when ripe, seeds loose in pulp, and usually crowned with calyx at the top, as in the Gooseberry; when the calyx is not present at the apex of a berrylike fruit, it is called baccate.

Bifid-Having two lobes or divisions about half-way through.

Bipinnatifid-A leaf twice divided in a pinnate or feather-like manner about half-way to the stalk or midrib.

Bristles-A term applied to stiff or rigid hairs.

Bulbs-The bulb is usually more or less globular, composed of fleshy scales (modified leaves crowded on a short stem, as in the Madonna Lily). In some bulbs the outer scales become thin and membranous and enclose the fleshy scales, as in the Onion. In the Garlic all the modified leaves are membranous and the leaf-buds developed in their axils are alone fleshy, these fleshy buds being called cloves.

Biserrate-Applied to the margin of a leaf where the margin is serrate, i.e., cut with oblique teeth like a large saw, each tooth being again cut with lesser saw-like teeth.

Bracts-Any leaf under a flower is a bract, whether scaly, coloured, or only a green leaf diminished in size. See Involucre and Phyllaries.

Calyx-The cup or outer row of floral leaves enclosing the rest of the flower, usually consisting of five pieces either free from each other as in the Buttercup, or united into a tube as in the Rose, only the upper portion being free.

Capsule-A fruit dry when ripe and opening at maturity, either by pores as in the Poppy, or by valves as in Stramonium, or transversely as in Henbane. It consists of two or many carpels.

Carpels-Fruits are composed of one or more modified leaves which bear on the margin one or more seeds. Each of these leaves is known as a carpel. In the Buttercup they are distinct, in the Pea and Bean only one is developed. In the Orange many are united. In the Cocoa Nut three are united, but their internal sides are absorbed.

Catkins-A spike of male or female flowers usually without petals or calyx, as in the Willow and Alder. In the Alder the bracts under the female flowers become hard and woody.

Channelled-Applied to leaves having the upper surface concave. 
Ciliate-Furnished with a row of hairs along the margin, like eyelashes.

Cluster crystals-Minute globes of crystals contained in leaf cells; sometimes called sphæraphides, and usually consisting of calcium oxalate.

Concentric-Having several circles inside one another.

Conchoidal - Having a fracture somewhat concave, with curved lines, as in Aloes.

Cordate-Shaped like the heart on playing cards.

Coriaceous-Having a leathery texture.

Corm-A more or less globular shortened stem, having membranous scales, but no fleshy ones, as in Colchicum and Crocus.

Corolla-Applied collectively to the inner row of coloured floral leaves, whether distinct or united into one piece. When the calyx and corolla are similar in colour and size, the term perianth is applied, as in the Lily and Hyacinth, in which there are two similar rows of three pieces; the outer row alternate and overlapping the inner row at the base.

Cortex-Applied to the outer separable portion of a stem or fruit.

Corymb-An arrangement of flowers in which the flowerstalks are of different lengths, but all rise to a level at the top, the outside flowers opening first. When the central flower opens first it is called a corymbose cyme.

Cotyledons-The seed lobes as seen when splitting open a nut or almond. They contain the nourishment to support the young plant while the root is being developed, when albumen is not present.

Crenate-Leaves having rounded, not saw-like, teeth.

Cruciform-Arranged like a Maltese cross, as in the flowers of the Wallflower, and other cruciferous plants.

Cuneate-Wedge-shaped.

Cuticle-The thin outer skin coating the epidermis, but not usually separable.

Cyme-This term is added to any inflorescence in which the central flower of the whole, or of a branch, opens first; thus the Elder has un umbellate cyme.

Deciduous-Falling off; applied to trees which are bare of leaves in winter, or to the flowers which fall when the truit forms. If the calyx falls off as the flower opens, as in the Poppy, it is said to be caducous.

Decurved-Curved downwards.

Dehiscence-A term applied to the opening of fruits. 
Dentate-Having sharp, nearly straight incisions in the margin of the leaf.

Didynamous-Having two stamens longer than the other two, as in plants of the Labiatce and Scrophulariacea.

Digitate-Having five or more narrow segments, as in the leaf of the Lupin.

Disc-The name given to a growth between the stamens and the pistil, as in the Ruta graveolens and to the centre of flowers in Composita.

Disciform-Shaped like a disc. Applied to the circular depressions on a rhizome where a deciduous stem has arisen, as in Solomon's Seal.

Efflorescence-Covered with a fine powder, which is not permanent.

Elliptic-Shaped like an ellipse.

Emarginate-Having an indentation at the apex of the leaf.

Embryo-The young plant in the seed, consisting of one or two cotyledons with a minute leaf-bud above, and a minute root below.

Endocarp-The inner layer of the fruit, corresponding to the inner surface of the carpel (which, like the leaf, has three layers). In the Plum the endocarp forms the stone, the inner layer or mesocarp forms the flesh, and the outer or epicarp forms the skin.

Entire-Not toothed at the margin.

Epidermis-The skin of the leaf. In the Windsor Bean leaf it can easily be peeled off.

Exfollating-Splitting off in layers like the bark of the Plane Tree and Sycamore.

Falcate-Curved like a scythe blade.

Feather-velned-Having the lateral veins proceeding straight to the margin, as in the leaf of Rhamnus Frangula.

Female piant-When the male and female flowers are on distinct plants. This arrangement is called dioicous, and when on separate flowers on the same plant, monoicous.

Filiform-Thread-shaped.

Florets or flowerlets-Applied to the central flowers in the flowerheads of the Composite. The central tubular florets are distinguished as florets of the disc, and the outer strap. shaped ones as florets of the ray.

Flowerheads-An arrangement of flowers in a compact group surrounded usually with several rows of bracts. See In. volucre and Phyllaries.

Fluorescence-Applied to liquids which present two different colours when viewed at different angles. 
Fluted-Cylindrical but channelled vertically like a column.

Foliaceous-Leafy. Applied to the Thallus, or stemless growths of Lichenes, Hepatice and Alge, when the segments are broad; also to bracts when they resemble the leaves except in being smaller.

Fracture-The transverse surface of a bark or root when broken; if not fibrous or in layers it is described as short.

Galbulus-A fleshy fruit consisting of three fleshy bracts united together, with naked seeds under each, i.e., having no proper ovary, as in the Juniper fruit. The three lines at the top indicate the lines of juncture of the bracts. The term is also applied to the rounded woody cone of some species of Cupressus.

Glands-Cells containing oily or mucilaginous secretions, sometimes forming a distinct receptacle as in the Eucalyptus Leaves, and sometimes forming the terminal head of a hair as in the Geranium, or they may be stalkless as in the Hop.

Halberd-shaped or hastate-Shaped like a halberd, as in the leaf of Rumex Acetosella.

Heartwood-The central portion of a tree trunk, often filled with a deposit of colouring matter or resin, as in Lignum vita.

Hermaphrodite-Having male and female organs, i.e., stamens and pistil, in the same blossom.

Hilum-The scar on a seed indicating where it has been attached by a stalk to the wall of the ovary; this name is also applied to the central spot in starch grains.

Imbricated-Overlapping like the tiles of a roof.

Imparipinnate-A pinnate leaf having an odd leaf at the apex.

Incise-serrate-The term incised is applied when the teeth are deeper at intervals.

Indusium-The membranous covering over the sori, or groups of spore cases, of ferns.

Inflorescence-The arrangement of flowers in plants.

Internodes-The intervals between the leaves on the stem.

Interruptedly pinnate-Having smaller leaflets between the ordinary leaflets, as in Agrimony.

Involucre-A ring of bracts outside a flowerhead in the Composite. In the Umbellifere the basal ring is called the general involucre, and the ring under the secondary umbels, the partial involucre.

Keeled-Having a projecting line underneath, or formed like the keel of a boat.

Laminate-Formed in thin layers. The name of lamina is also given to the blade or flat part of a leaf. 
Lanceolate-Oval, but pointed at both ends, like a lance head.

Leaflet-The parts of a compound leaf when they are divided down to the midrib or rachis.

Legume-A fruit consisting of a single carpel, which opens on one side only, corresponding to the margin of the carpellary leaf.

Lenticels-Corky developments of the stomata or breathing pores of the bark.

Lenticular-Shaped like a lens, as in the Lentil.

Lichen-A group of cryptogamic plants growing on rocks and trees, usually greyish or yellowish, without distinction of stem and leaf, but variously branched. The fructification forms a small disc, usually brown or blackish on the surface, or black points, dots, or lines.

Ligulate-Strap-shaped.

Lyrate-Applied to pinnatifid leaves in which the terminal lobe is larger than the others and rounded.

Medullary rays-Slender lines of soft tissue that connect the pith with the bark; usually paler than the wood, as seen in a transverse section of the wood.

Micropyle-The minute opening of the seed through which the radicle of the embryo pushes out. In the Bean it can be seen near the hilum.

Moss-Minute plants with green leaves with or without a single vein, or a forked vein, and bearing stalked or stalkless capsules, usually opening transversely, containing spores, and often furnished with teeth.

Mucronate-Furnished with a short sharp point at the apex.

Muller-shaped-Shortly cylindrical with one end flat and the opposite one rounded, like a muller.

Multicellular-Hairs, or fruits, composed of many cells.

Mycelium-The loose thread-like mass forming the plant of fungi. In the Mushroom it is loose and cottony, and known as mushroom spawn; in Ergot it is compacted into a hard mass known as a sclerotium.

Node-The point of the stem whence the leaves arise.

Nucleus sheath-The line in endogenous roots which separates the outer ring from the central portion.

Nut-A fruit originally composed of three carpels, which ultimately becomes one-celled, and contains one seed, as in the Cocoa Nut and Hazel Nut. In the young state the three carpels are indicated by the presence of three stigmas.

Oblanceolate-Lanceolate, but wider at the upper end. As a rule the prefix $o b$ means the reverse shape.

Obovate-Ovate reversed. 
Opposite-Applied to leaves when two arise from opposite sides of the same node.

Ovary-The young fruit containing seeds, surmounted by a stigma, or a stigma borne on a stalk called the style. The stigma represents the apex of the carpellary leaf, and therefore indicates the number of carpels present in the fruit, as in the Poppy fruit. The presence of the stigma distinguishes a small fruit from a seed.

Ovoid-Nearly, but not quite, egg-shaped.

Palea-The two scale-like bracts enclosing the stamens and pistil in the flower of a grass, the outer usually larger and often furnished with an awn; also the membranous scales forming the bract of each floret of the disc in the flowerhead of the Compositce.

Palisade-Closely-packed, narrow, cylindrical cells forming the upper half of the leaf under the epidermis in most plants.

Palmate-Shaped like the palm of the hand, with five or more lobes, as in the Sycamore leaf.

Panicle-An inflorescence in which the first branches are branched again, the outside flowers of each branch opening first.

Papilionaceous-Shaped liked a Pea blossom.

Papilla-Small raised points, or very short threads.

Pappus-The limb of the calyx in a composite flower, the veins being developed in the form of hairs; if the hairs are simple the pappus is said to be pilose; if feathery, i.e., laterally branched, it is called plumose.

Pericarp-The whole of the husk of the fruit, consisting of three layers-epicarp, mesocarp, and endocarp.

Petals-The inner, usually coloured, row of the leaves of the flower.

Petiole-The stalk of the leaf.

Phyllaries-The bracts forming one or more rings outside the flowerhead of a composite flower.

Pilose-See Pappus.

Pinnate-Divided in a feather-like manner to the rachis. When there are smaller leaflets between the larger ones, the leaf is said to be interruptedly pinnate; if the leaflets are in pairs with a terminal odd one, it is imparipinnate.

Pinnatifid-Divided in a feather-like fashion about half-way to the midrib or rachis.

Pinnatisect-A pinnate leaf divided about three-quarters of the distance to the midrib. 
Pistillate-The flower bearing the female organ or pistil, which consists of ovary, style, and stigma.

Pitted-Having very small depressions.

Placenta-The portion of the ovary to which the seeds are attached. It usually consists of the thickened edges of the carpellary leaf turned inside the ovary, but sometimes is a growth formed from their edges, as in the Poppy capsule.

Procumbent-Prostrate branches with the end slightly raised.

Protosalt-Salts consisting of the lower oxide of metals combined with an acid; they contain less oxygen than the persalts, and usually differ in colour, e.g., the protosalts of iron are green, and the persalts, red.

Pubescent-Having short downy hairs.

Pyrenes-The fruit of the Labiata and Boraginacea, resembling seeds, but each consisting of a half carpel containing one seed.

Pyriform-Shaped like a pear.

Quilled-Applied to bark which becomes inrolled when dry, as in Cinnamon and Cinchona.

Raceme-An inflorescence in which flowers having stalks of equal length are arranged along a central stem, the lowest flower opening first.

Rachis-The backbone or central rib of a large, much-divided leaf, like a Fern.

Radical-Leaves arising from the top of the root or rootstock.

Raphe-A thread in the inner seed coat consisting of vessels connecting the interior of the ovule with the placenta, as in the Orange seed.

Raphides-Needle-like crystals of oxalate of calcium, found in the cells of plants, as in the Squill root.

Receptacle-The name given to the disc-iike top of the stem to which the florets of a composite flower are attached. The same name is also given to the cavities in plant tissues containing oil or mucilage.

Reniform-Shaped like a kidney.

Reticulated-Covered with a network of veins or lines.

Revolute-Rolled back at the edges.

Rhizome-A prostrate stem more or less embedded in the soil, giving off leaves from the upper, and roots from its lower, surface. The name is also sometimes given to the short upright stem covered with the remains of fallen leaves, and ringed, as in Gentian root. This is preferably distinguished as the rootstock, as it is stem continuous with the root.

Rhombic-Shaped like a rhomb. 
Rhomboidal-Irregularly rhombic.

Rootstock-See Rhizome.

Rosettes-Leaves closely and spirally arranged, as in the Houseleek and in the double flower of the Rose.

Rotate-Wheel-shaped.

Ruminated-Albumen is said to be ruminated when the inner seed coat is folded into its substance, as in the Nutmeg and Areca Nut.

Scyphi-The wineglass-like organ bearing the fructification at the apex in the genus of lichens called Cladonia.

Secondary umbels-Called also partial umbels; when each stalk of an umbel bears a smaller or secondary umbel at its apex.

Serrate-Having oblique teeth like a saw.

Sessile-Having no leafstalk, and therefore, so to speak, sitting on the stem.

Sinuate-Having incisions rounded at the base, as in the Oak leaf.

Spatulate-Shaped like a spatula or flattened spoon.

Spike-An inflorescence in which flowers without stalks are arranged along a central stem, either loosely or densely, as in Agrimony and Plantain.

Spine-The hardened projecting vein of a leaf, as in the Holly and Thistle.

Spore cases-Receptacles containing spores.

Spur-A more or less tubular projection at the base of the corolla, as in the Toadflax and Columbine.

Stamens-The male organ of the flower, consisting of two anthers, usually oblong or reniform in shape, containing pollen, and often borne on a stiff thread or filament.

Staminode-A barren stamen, containing no pollen, as in Scrophularia.

Stellate-With rays like a star.

Stigma-The sticky apex of the style of the female organ of the flower, to which pollen is carried by insects or the wind.

Stipules--Small leaf-like organs, at the base of the leafstalks, or attached to the stem between the leaves. In the Poly. gonacea membranous stipules form a sheath, called an ochrea, round the stem.

Stipulets or stipels-Small leaflets at the base of the leaflets in compound leaves, as in the Dwarf Elder.

Stomata-Microscopic openings in the surface of the leaf, mostly on the under surface, whereby air enters the tissues. 
Stone cells-Cells hardened by internal deposits, appearing to the naked eye or under a lens as hard points, in bark, \&c.

Striated-Marked with more or less parallel lines.

Style-The filament connecting the stigma and ovary.

Subulate-Shaped like an awl.

Suckers-Underground branches from the stem or root that arise at a distance from the stem, as in the Raspberry.

Syconus-A name given to the fruit of the Fig, derived from the Greek name of the Fig.

Tangential-A vertical section at right angles to the centre of the stem.

Terminal-At the end of a shoot or branch.

Ternate-A leaf divided into three distinct segments.

Tetrahedral-Having four sides.

Thallus-The flat branching growth, of uniform texture, of cryptogams.

Toothed-More or less pointed equal-sided incisions in the margin of the leaf.

Tortuous-Twisted and undulated.

Trifid-Nearly divided into three segments.

Trifoliate-Having three distinct leaflets, as in Clover and Bogbean.

Tripinnate-Three times divided in a pinnate manner.

Truncate-Appearing as if cut off at the end, as in the leaf of the Tulip Tree.

Tuber-An underground, more or less globular stem, bearing leaf-buds, as in the Potato and Artichoke.

Umbel-An arrangement of flowers having stalks proceeding from one point, and of equal length, so as to form a level surface, the outer flowers opening first.

Unisexual-Flowers having either stamens or pistils, but not both together.

Vascular-Consisting of vessels or minute tubes.

Vitta-The oil receptacles in the fruits of the Umbelliferc; they usually appear as dark vertical lines between the ridges of the fruit.

Whorl-A circle of leaves around a node, as in Galium. 


\section{Botanical Names and the}

\section{Authorities for them.}

THE necessity for giving in abbreviation the name of the botanist who is responsible for the name of a plant naturally seems, to the uninitiated, a waste of space and of printer's ink, and a brief explanation is therefore necessary. The necessity arises from the fact that the same name in many cases has been applied by different

$\because$ botanists to different plants, in ignorance that the name had already been given to some other plant; or cases have occurred in which a botanist has confused two different plants and described them as one plant, in which case some subsequent botanist with a wider knowledge and a more critical eye has had to separate them, so that the name first used no longer represents the plant accurately.

Under these circumstances, when, for instance, the same name has been used for five different plants, if the bare name were given without that of the botanist who applied it to the particular plant, it would be impossible to be sure which of the five plants the writer meant, and in a phàrmacopœia or work on medicinal plants, giving the name of the plant alone, would lead to endless confusion, and probably to unexpected results. The reason for abbreviating the names is to save space, and because at any botanical library the librarian would easily be able to trace the name in Pritzel's Thesaurus Literature Botanica, up to 1877 (the year in which it 
was published), and for names since that date, the botanists at any botanical department of a museum or botanic gardens, where the plant could be seen, would recognise the abbreviated names. It is true that in some cases where the abbreviations have been reduced to initials like L. \& DC. and H.B., \& K., librarians might not know to whom the letters referred. The recognised custom of using the first syllable of the name and the next letter, or in cases where this rule would leave a difficulty owing to the next letter after the first syllable being the same, the last letter or two last letters of the name should be used; thus, Decaisne could be distinguished from Decandolle by writing it Decne. In some cases there have been father, son, and even grandson of the same name, and in such cases it has been customary to write f. (filius) after the name for the son, thus, in the case of Hooker and Linnæus it would be Hook. f. \& Linn. f. ; but it is much more helpful to the student to give the initials of the Christian name in each case, thus, C. A. Agardh and J. G. Agardh or W. J. Hooker and J. D. Hooker, as the student cannot intuitively know which is the father and which is the son. In the case of Linnæus, father and son, the son having the same Christian name, but ennobled, the abbreviation could be written Linn. C. von, the point to be aimed at being to eliminate as far as possible all sources of error and to save the time of the student of botany by making reference to books as simple and easy as possible. This has been done to an enormous extent by the Index Kervensis, by giving a reference to the work in which any plant has been first described, under the names of the plants, alphabetically arranged, so that by means of Pritzel's Thesaurus Literature Botanica and the Index Kewensis it is possible to refer to the original and accepted description of any known plant. 


\section{ABBREVIATIONS OF NAMES OF AUTHORS OF BOTANICAL NAMES.}

Ach... $\quad$.. $\quad$.. Acharius, Erik

Adam .. .. Adam, Johann Friedrich

Ait. .. $\quad$.. .. Aiton, William Townsend

Allem. .. .. Allemao, Francisco Freire

Aguiar .. .. Aguiar, J. M. de (Phar. Jour. (3) x. p. 42)

Arn. .. $\quad$.. .. Arnott, George Arnold Walker

Aublet .. .. Aublet, Jean Baptiste Christophore Fusée

Baill. $\quad$.. .. Baillon, Henri Ernest

Baker .. .. Baker, John Gilbert

Bart. \& Wendl. .. $\left\{\begin{array}{l}\text { Bartling, Friedrich Gottlieb } \\ \text { Wendland, Heinrich Ludwig }\end{array}\right.$

Beauv. .. .. Beauvois, A. M. T. J. Palisot

Benn. .. .. Bennett, John Joseph

Benth. .. .. Bentham, George

Bercht. .. .. Berchtold, Friedricb, Graf von

Berg \& Schmidt $\cdots\left\{\begin{array}{l}\text { Berg, Otto Carl } \\ \text { Schmidt, C. F. }\end{array}\right.$

Bernh. .. .. Bernhardi, Johann Jakob

Bieb... .. .. Bieberstein, L. B. Fr. Marschal von

Blume .. .. Blume, Carl Ludwig

Boiss. \& Buhse $\quad \cdots\left\{\begin{array}{l}\text { Boissier, Edmond } \\ \text { Buhse, F. }\end{array}\right.$

Borkh. .. .. Borkhausen, Moritz Balthasar

Buch.-Ham. .. Buchanan-Hamilton, Francis

Burm. .. .. Burmann, Johannes

Brown .. .. Brown, Robert

Carr. .. .. Carrière, Élie Abel

Cav,.. .. .. Cavanilles, Antonio José 
Chaix .. .. Chaix, Dominique, Abbé

Chamisso .. .. Chamisso, Adalbert von

Choisy .. .. Choisy, Jacques Denys

Colebr. .. .. Colebrooke, Henry Thomas

Correa .. .. Correa da Serra, José Francisco

Crantz .. .. Crantz, Heinrich Johann Neptomuk von

Cyrill. .. .. Cyrillus, Patriarch of Alexandria

DC. .. .. . . De Candolle, Augustin Pyramus

Del... .. .. Delile, Alire Raffeneau

Desf. .. .. Desfontaines, Rene Loniche

Desr. .. .. Desrousseaux, Louis Augustin Joseph

Don, G. .. .. Don, George

Dry... .. .. Dryander, Jonas

Dunal .. .. Dunal, Michel Felix

Dur... .. .. Du Roi, Johann Philipp

Ehrh. .. .. Ehrhart, Friedrich

Ell. .. .. .. Ellis, John

Eng... .. .. Engler, Adolf

Fisch. .. .. Fischer, Friedrich Ernst Ludwig von

Forsk. .. .. Forskål, Pehr

Forst. .. .. Forster, John Heinhold

Fries. .. .. Fries, Elias Magnus

Gaertn. .. .. Gaertner, Joseph

Goldb. .. .. Goldbach, Karl Ludwig

Grah. .. .. Graham, John

Gray, A. .. .. Gray, Asa

Greene .. .. Greene, Edward Lee

Haenke .. .. Haenke, Thaddæus

Hance .. .. Hance, Henry Fletcher

Haw. .. .. Haworth, Adrian Hardy

Hayne .. .. Hayne, Friedrich Gottlob

Henn. .. .. Henning, Paul

Heyne .. .. Heyne, Benjamin

H., B., \& K. $\quad .\left\{\begin{array}{l}\text { Bonpland, Aime } \\ \text { Bond, }\end{array}\right.$ Kunth, Karl Sigismund 
Hoffm. .. .. Hoffmann, George Franz

Holmes .. .. Holmes, Edward Morell

Hook. f. .. ... Hooker, (filius), James Dalton

Houtt. .. .. Houttyn, Martin

Huds. .. .. Hudson, William

Jacq. .. .. Jacquin, Joseph von

Kar. \& Kir. $\quad$. $\left\{\begin{array}{l}\text { Karelin, Georg } \\ \text { Kirilow, Johann }\end{array}\right.$

Ker-Gawl. .. . . Ker, John Bellenden, alias Gawler

King $\quad$.. .. King, George

Koch .. .. Koch, Wilhelm Daniel Joseph

Klotzsch .. .. Klotzsch, Johann Friedrich

Kunth $\quad$. . . Kunth, Karl Sigismund

Kuntze $\quad$.. .. Kuntze, Otto

Kütz. . .. Kützing, Friedrich, Traugott

Labill. . . . . Labillardiere, Jacques Julien Houton de

Lam. or Lamk. .. $\begin{aligned} & \text { La Marck, Jean Baptiste Antoine } \\ & \text { Pierre Mounet, Chevalier }\end{aligned}$

Lamb. .. . . Lambert, Aylmer Bourke

Lemaire .. .. Lemaire, Charles

Léveillé . . . Léveillé, Joseph Henri

L'Hérit. .. .. L'Héritier de Brutelle, Charles Louis

Lindl. .. .. Lindley, John

Linn. $\quad$.. . . L Linnæus, Carl

Linn. f. .. .. Linnæus (filius), Carl von

Loisel. .. .. Loiseleur-Deslongchamps, Jean Louis Auguste

Marsh. .. .. Marshall, Humphry

Mart. .. .. Martius, Karl Friedrich Philipp von

Maton .. .. Maton, William George

Medik. ... .. Medikus, Frederich Casimir

Mich. or Michx. .. Michaux, Andre

Miers $\quad$.. .. Miers, John

Mill. $\quad$.. .. Miller, Philip

Miq. $\quad$.. $\quad$.. Miquel, Friedrich Auton Wilhelm

Mœnch .. .. Mœnch, Konrad

Mol. $\quad$.. .. Molina, Juan Ignazio 
Muell., F. .. .. Mueller, Ferdinand von

Muhl. .. .. Muhlenberg, Henry

Murr. .. .. Murray, Johann Andreas

Neck. $\quad$.. . . Necker, Noel Joseph de

Nees. . . . Nees von Esenbeck, Christian Gottfried Nees, T. \& Eberm. $\left\{\begin{array}{l}\text { Nees von Esenbeck, Theodor Fried- } \\ \text { rich Ludwig } \\ \text { Ebermaier, Karl Henrich }\end{array}\right.$

Nichols. .. .. Nicholson, George

Nutt. .. .. Nuttall, Thomas

Oliver, D. .. . . O Oliver, Daniel

Oliver .. .. Olivier, Guillaume Antoine

Ort. .. .. .. Ortega, Casimir Gomez

Pav... .. . . Pavon, José

Pell. or Pellet. .. Pelletier-Sautelet-

Ph. Journ. (1) viii. p. 574

Pers. $\quad$.. $\quad$.. Persoon, Christian Hendrik

Planch. .. .. Planchon, Gustav

Pohl _. .. Pohl, Johann Emmanuel

Presl .. .. Presl, Karel Boriwog

Pursh _. .. Pursh, Friedrich Traugott

Rafin. .. .. Rafinesque, Schmaltz Constantino

Reg... .. .. Regel, Edward

Rich., A. .. .. Richard, Achille

Risso .. .. Risso, J. A.

Rosc. .. .. Roscoe, William

Ross- .. .. Ross, John

Roth .. .. Roth, Albrecht Wilhelm

Roxb. .. .. Roxburgh, William

R. \& P.

.. $\left\{\begin{array}{l}\text { Ruiz, Lopez Hipolito } \\ \text { Pavon, Joseph }\end{array}\right.$

R. \& S. $\quad \cdots \quad \cdots\left\{\begin{array}{l}\text { Rœmer, Johann Jakob } \\ \text { Schultes, Joseph Auguste }\end{array}\right.$

Salisb. .. .. Salisbury, Richard Antony

Schlecht. .. .. Schlectendal, Diedrich Friedrich Leon-

Schott .. .. Schott, Heinrich Wrhelm

Schrad. .. .. Schrader, Heinrich Adolplus 
Schreb. .. $\quad$.. Schreber, Johan Daniel Christian von

Schum. .. .. Schumann, Karl

Scop. $\quad$.. $\quad$. Scopoli, Johann Anton

Sieb. \& Zucc. $\quad .\left\{\begin{array}{l}\text { Siebold, Philip Franz von } \\ \text { Zuccarini, Joseph Gerhard }\end{array}\right.$

Sims.. $\quad$.. .. Sims, John

Sm. .. $\quad$.. $\quad$.. Smith, Sir James Edward

Soland. .. .. Solander, Daniel

Spreng. .. .. Sprengel, Kurt

Stackh. .. .. Stackhouse, John

Stapf _.. .. Stapf, Otto

Steinh. . . .. Steinheil, Adolf

Steud. .. .. Steudel, Ernest Gotlieb

St. Hil. $\quad$.. $\quad$. $~ S t$. Hilaire, Augustin Francois Cesar,

Stokes _. .. Stokes, Jonathan

Sw. .. $\quad$.. $\quad$.. $\quad$ Swartz, Olaf

Sym. .. . . Symons, Jelinger

Tausch $\quad$.. $\quad$.. Tausch, Ignaz Friedrich

Thunb. .. .. Thunberg, Carl Pehr

Torr. .. .. Torrey, John

Trev. $\quad$.. .. Trevisan, Victore Conte

Triana .. $\quad$.. Triana, José

Tul. .. $\quad$.. $\quad$.. Tulasne, Louis René

Vahl .. .. Vahl, Martin

Vis. .. $\quad$.. .. Visiani, Roberto de

Walt. .. .. Walter, Thomas

Warb. .. .. Warburg, Otto

Wats., S. .. .. Watson, Sereno

Web. $\quad$.. .. Weber, Friedrich

Weddell .. $\quad$.. Weddell, Hugh Algernon

Wend. .. .. Wenderoth, Georg Wilhelm Franz

W. \& K. .. $\quad \cdots\left\{\begin{array}{l}\text { Waldstein, Franz Adam Graf von } \\ \text { Kitaibel, }\end{array}\right.$

Willd. .. .. Willdenow, Karl Ludwig 


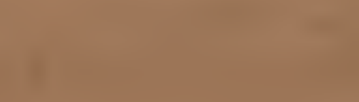

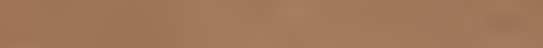

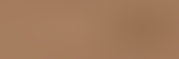

(1)

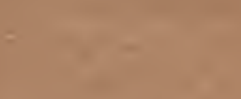

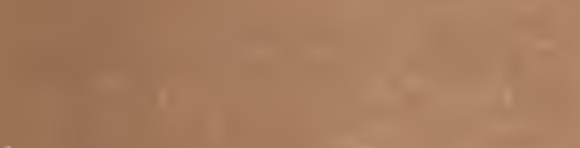

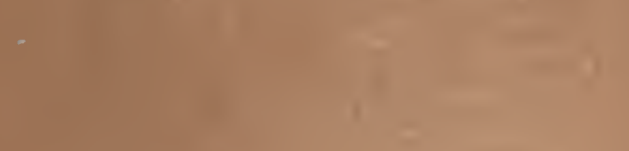
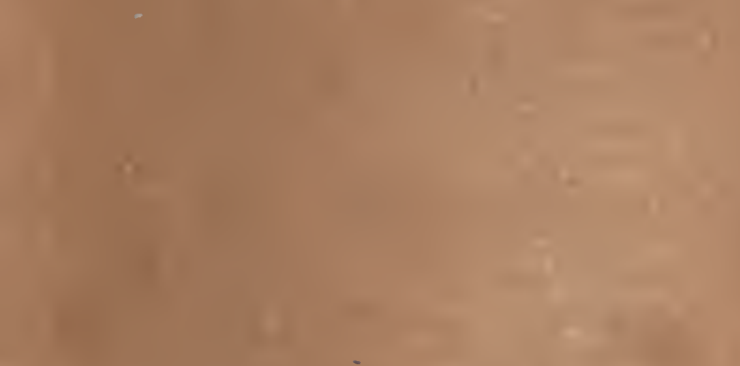

$$
\text { - }
$$





\section{SOUTHERN REGIONAL LIBRARY FACILITY}

405 Hilgard Avenue, Los Angeles, CA 90024-1388

Return this materlal to the Ilbrary from which it was borrowed.

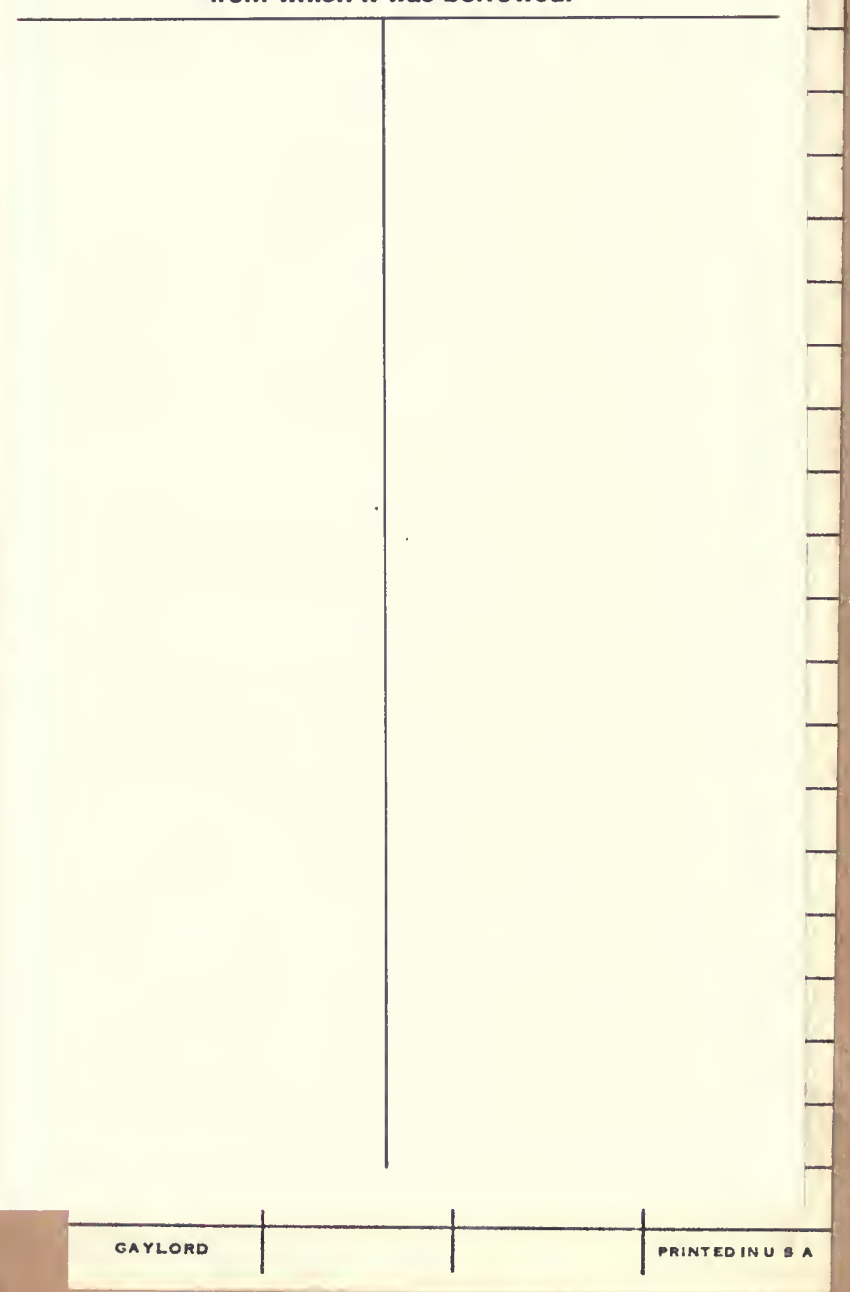




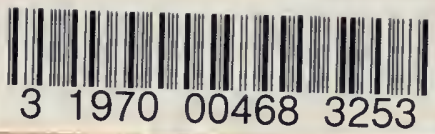

UC SOUTHERN REGIONAL LIBRARY FACIITY

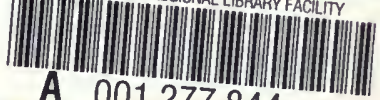

A $001277844_{5}$ 
Univ

S 